\title{
Site U1334'
}

\author{
Expedition 320/321 Scientists ${ }^{2}$
}

\section{Chapter contents}

Background and objectives. ......... 1

Science summary.................. 2

Operations.................6

Lithostratigraphy.............. 7

Biostratigraphy ............... 10

Paleomagnetism ................ 14

Geochemistry ................ 16

Physical properties .............. 18

Stratigraphic correlation and composite

section..................... 19

Downhole measurements . . . . . . . . . . . . 21

References................... 21

Figures.................... 24

Tables.................... 78

${ }^{1}$ Expedition 320/321 Scientists, 2010. Site U1334. In Pälike, H., Lyle, M., Nishi, H., Raffi, I., Gamage, K., Klaus, A., and the Expedition 320/321 Scientists, Proc. IODP, 320/321: Tokyo (Integrated Ocean Drilling Program Management International, Inc.).

doi:10.2204/iodp.proc.320321.106.2010

'Expedition 320/321 Scientists' addresses.

\section{Background and objectives}

Integrated Ocean Drilling Program (IODP) Site U1334 $\left(7^{\circ} 59.998^{\prime} \mathrm{N}, 131^{\circ} 58.408^{\prime} \mathrm{W} ; 4799\right.$ meters below sea level [mbsl]) (Fig. F1; Table T1) is located $\sim 380 \mathrm{~km}$ southeast of previously drilled Ocean Drilling Program (ODP) Site 1218 ( 42 Ma crust) in the central area drilled during the Pacific Equatorial Age Transect (PEAT) program (IODP Expedition 320/321). Site U1334 ( 38 Ma crust) is situated $\sim 100 \mathrm{~km}$ north of the Clipperton Fracture Zone on abyssal hill topography draped with $\sim 280 \mathrm{~m}$ sediment (Fig. F2). The fabric of the abyssal hills within the sites is oriented either due north or slightly east of due north.

Water depth in the vicinity of Site U1334 ranges between 5.0 and $5.1 \mathrm{~km}$ for the depressions between the abyssal hills. The abyssal hills range between 4.70 and $4.85 \mathrm{~km}$ water depth and generally show a thicker and more consistent sediment cover than the basins. In fact, a significant amount of the bathymetric difference between hills and basins is controlled by the amount of sediment cover. The comparison of sediment thickness and clarity of seismic sections led us to select a location on the middle elevation of one of the abyssal plateaus.

Site U1334 sediments were estimated to have been deposited on top of late middle Eocene crust with an age of $\sim 38 \mathrm{Ma}$ and target the events bracketing the Eocene-Oligocene transition with the specific aim of recovering carbonate-bearing sediments of latest Eocene age prior to a large deepening of the calcium carbonate compensation depth (CCD) that occurred during this greenhouse to icehouse transition (Kennett and Shackleton, 1976; Miller et al., 1991; Zachos et al., 1996; Coxall et al., 2005). The EoceneOligocene transition experienced the most dramatic deepening of the Pacific CCD during the Paleogene (van Andel, 1975), which has now been shown by Coxall et al. (2005) to coincide with a rapid stepwise increase in benthic oxygen stable isotope ratios, interpreted to reflect a combination of growth of the Antarctic ice sheet and decrease in deepwater temperatures (DeConto et al., 2008; Liu et al., 2009).

So far the most complete Eocene/Oligocene boundary section recovered from the equatorial Pacific has been at Site 1218 on $42 \mathrm{Ma}$ crust; however, it is far from exceptionally preserved. Carbonate weight percentages drop markedly below the boundary and reach 0 wt $\%$ near 34 Ma during a time of apparent global shoaling of the CCD just prior to the Eocene-Oligocene transition and CCD deepening 
(Bohaty et al., 2008). This prevented the recovery of information about paleoceanographic conditions prior to the Eocene-Oligocene transition and also has implications for the interpretation of paleotemperature proxies such as $\mathrm{Mg} / \mathrm{Ca}$ ratios in foraminifer shells that were bathed in waters with very low carbonate ion concentrations (Lear et al., 2008). The integrated stratigraphy from Site 1218 has been correlated to the planktonic foraminifer marker extinction of Hantkenina in exceptionally well preserved shallow clay-rich sediments from Tanzania described by Pearson et al. (2008), who demonstrated that the Eocene/Oligocene boundary falls within the middle plateau of the stable isotope double-step described by Coxall et al. (2005), just prior to the base of magnetochron C13n (Fig. F3).

Data from Site 1218 allowed the astronomical time calibration of the entire Oligocene (Coxall et al., 2005; Wade and Pälike, 2004; Pälike et al., 2006b), but the lack of carbonate in the uppermost Eocene at this site made the detailed time control now available for the Oligocene much less certain for the late Eocene. Site U1334 is located on crustal basement age of $\sim 38 \mathrm{Ma}$ and crossed the paleoequator shortly thereafter. It was located to provide the missing information about the crucial chain of events prior to and during the Eocene-Oligocene transition. We positioned Site U1334 and the other PEAT sites south of the estimated paleoequatorial position at their target ages in order to maximize the time that drill sites remain within the equatorial zone (i.e., $\pm 2^{\circ}$ of the equator), to allow for some southward bias of the equatorial sediment mound relative to the hotspot frame of reference (Knappenberger, 2000), and to place the interval of maximum interest above the basal hydrothermal sediments. We located Site U1334 using the seafloor digital age grid from Müller et al. (1997), heavily modified and improved with additional magnetic anomaly picks from Petronotis (1991), Petronotis et al. (1994), and Deep Sea Drilling Project (DSDP)/ODP basement ages. For this grid, each point is then backrotated in time to zero age using the fixed-hotspot stage-poles from Koppers et al. (2001) and Engebretson et al. (1985) and the paleopole data from Sager and Pringle (1988). From the backtracked latitudes for each grid point we then obtained the paleoequator at the crustal age by contouring. The nearest older drill locations in this plate segment bounded by the Clipperton Fracture Zone nearby to the south and the Clarion Fracture Zone to the north are DSDP Site 160 (with a crustal age of $\sim 35 \mathrm{Ma}$ ) to the east and Site 1218 (with a crustal age of $42 \mathrm{Ma}$ ) to the west, lending support to our backrotation modeling.
One of the common objectives of the PEAT program for all sites is to provide a limited depth transect for several Cenozoic key horizons, such as the EoceneOligocene transition (Coxall et al., 2005). For this objective, Site U1334 will form the youngest and shallowest paleodepth constraint, with an estimated crustal paleodepth of $\sim 3.5 \mathrm{~km}$ during the EoceneOligocene transition. Site U1334 also targets the Oligocene/Miocene boundary and the Mi-1 event (Zachos et al., 2001; Pälike et al., 2006a), again as part of a limited depth transect. Site U1334 is estimated to have been $\sim 4.2 \mathrm{~km}$ below sea level at that time ( 23 Ma).

All Expedition 320/321 drill sites have in common the objective to improve and extend the extensive intercalibrated bio-, magneto-, chemo-, and astronomical stratigraphies for the Cenozoic (e.g., Shackleton et al., 2000; Pälike et al., 2006b).

The 48-channel stacked and migrated data (Fig. F2) (Pälike et al., 2008; Lyle et al., 2006) allowed us to optimize the Site U1334 position on the intersection of seismic Lines 1 and 6 from the AMAT-03 survey. Site U1334 was located at the crossing position because the sediment and basement are well imaged. Any additional thickness away from the cross of Lines 1 and 6 was primarily caused by additional Miocene sediment on top and not by the section of primary interest below. We estimated sediment thickness using interval velocities published for ODP Site 574 by Mayer et al. (1985). The subbottom profiler sections image $\sim 20 \mathrm{~m}$ of transparent surface sediment and $\sim 100 \mathrm{~m}$ of layered sediments in the upper sediment column (Pälike et al., 2008).

Site survey piston Core RR0603-8JC was taken west of Site U1334 (Fig. F1B). The survey piston core lithology consists of a surface layer of siliceous clay over upper Miocene to upper middle Miocene radiolarian oozes, devoid of carbonate. The age at the base of this core is $\sim 12.4 \mathrm{Ma}$ based on radiolarian assemblages. An interpretation of the site survey seismic data (Fig. F2) indicated that Site U1334 might penetrate seismic reflectors Orange (O), P5, and P4 of Lyle et al., (2002). The predicted ages for the latter two can be confirmed by coring (see "Science summary").

\section{Science summary}

Three holes were cored at Site U1334 $\left(7^{\circ} 59.998^{\prime} \mathrm{N}\right.$, $131^{\circ} 58.408^{\prime} \mathrm{W}$; $4799 \mathrm{mbsl}$ ) (Fig. F1; Table T1), targeting the events bracketing the Eocene-Oligocene transition as part of an investigation of the wider Cenozoic climatic evolution (e.g., Zachos et al., 2001) and providing data toward a depth transect across the Oligocene (see "Eocene/Oligocene Boundary 
[Site U1334; 38 Ma crust]" in the "Expedition summary" chapter) that will allow exploitation and verification of a previous astronomical age calibration from Site 1218 (Pälike et al., 2006a).

Site U1334 is in the center of the PEAT program transect, $100 \mathrm{~km}$ north of the Clipperton Fracture Zone and $\sim 380 \mathrm{~km}$ southeast of the previously drilled Site 1218. At Site U1334, seafloor basalt is overlain by $\sim 285 \mathrm{~m}$ of pelagic sediment. The oldest sediment is of late middle Eocene age (38 Ma).

The topmost $\sim 47 \mathrm{~m}$ thick lithologic Unit I contains a $15 \mathrm{~m}$ thick interval of brown radiolarian clay overlying $\sim 32 \mathrm{~m}$ of alternating radiolarian clay and nannofossil ooze. The uppermost section (320-U1334A-1H$\mathrm{CC}$ ) is of late Miocene age (radiolarian Zone RN7; $\sim 8.5 \mathrm{Ma}$ ). Below, Unit II comprises a $\sim 200 \mathrm{~m}$ thick succession of upper Miocene to Oligocene nannofossil ooze and chalk above a $\sim 35 \mathrm{~m}$ thick sequence of upper Eocene nannofossil chalk, radiolarite, and claystone (Unit III). Basal lithologic Unit IV $(\sim 1 \mathrm{~m}$ thick) consists of middle Eocene intercalated micritic chalk and limestone on basalt (Figs. F4, F5).

Holes U1334A-U1334C provided high-quality APCcored sediments from the mudline to $\sim 210 \mathrm{~m}$ core depth below seafloor (CSF) (Cores 320-U1334A-22H, 320-U1334B-22H, and 320-U1334C-22H). Below this depth we encountered increasingly stiffer and harder sediment, after which we switched to the extended core barrel (XCB) cutting shoe. XCB coring advanced to $288.5 \mathrm{~m}$ drilling depth below seafloor (DSF) through lower Oligocene and Eocene sediments with high recovery. At the base of the holes, an intercalated unit of basalt and hard micritic chalk and limestone occurs below a 10-20 m thick section of nannofossil ooze and chalk. For detailed coring activities, see "Operations."

Carbonate content exceeds $92 \mathrm{wt} \%$ in the upper lower Miocene below Section 320-U1334A-5H-3 and remains high throughout the Oligocene. Eocene sediments still contain considerable amounts of carbonate, and nannofossil ooze and chalk are dominant lithologies apart from several short less carbonate rich intervals (e.g., Section 320-U1334A-28X-3). In the middle Eocene, carbonate content cycles between $\sim 40$ and $85 \mathrm{wt} \%$ (see "Geochemistry") (Fig. F6), with higher values encountered toward the basal part of the Eocene section. Two short intervals in the upper Eocene ( $\sim 249$ to $\sim 257$ m CSF) exhibit carbonate content of $<20 \mathrm{wt} \%$.

A series of middle Oligocene cores (Cores 320U1334A-16H through $21 \mathrm{H}$ ) were recovered that had very distinct colors ranging from light grayish green to light blue (see "Lithostratigraphy"). These uniquely colored carbonate oozes exhibit extremely low magnetic susceptibilities that complicated stratigraphic correlation. These oozes have lost almost their entire magnetic susceptibility signal from $~ 145$ to $\sim 215 \mathrm{~m}$ CSF (Figs. F5, F7). Similar colored cores have previously been described for DSDP Sites 78 and 79 (Hays et al., 1972).

The Eocene-Oligocene transition at Site U1334 is much more expanded than at IODP Sites U1331U1333 and even Site 1218. The transition was encountered at $\sim 250 \mathrm{~m} \mathrm{CSF}$ and fully recovered in Cores 320-U1334A-27X and 320-U1334B-26X; Hole U1334C was used to fill small stratigraphic gaps. The Oligocene-Miocene transition was fully recovered in all three holes in Cores 320-U1334A-10H (based on magnetostratigraphy, the boundary is at Sample 320U1334A-10H-6, $98 \mathrm{~cm}$ ), 320-U1334B-10H (top of Section 2), and 320-U1334C-10H.

All major microfossil groups occur in sediments from Site U1334 and provide a consistent, coherent, and high-resolution biostratigraphic succession spanning a near-continuous sequence from the middle Miocene to the uppermost middle Eocene. The uppermost $12 \mathrm{~m}$ of radiolarian clay is barren of calcareous microfossils but contains radiolarians of middle Miocene age, similar to the site survey piston Core RR0306-08JC (Lyle et al., 2006). Nannofossil ooze and radiolarian clays are present in the Miocene and Eocene parts of the section, with nannofossil ooze dominant in the thick Oligocene section. Radiolarians are present through most of the section, apart from the lowermost cores, and are well preserved in the Eocene. They provide a coherent high-resolution biochronology and indicate a complete sequence of radiolarian zones from RN7 (upper Miocene) to RP17 (uppermost middle Eocene). Calcareous nannofossils are present and moderately to well preserved through most of the succession, and there appears to be a complete sequence of nannofossil zones from NN6 (middle Miocene) to NP17 (uppermost middle Eocene), providing a minimum age estimate for basaltic basement of $38 \mathrm{Ma}$. In the Eocene, the base of Chiasmolithus oamaruensis is determined in Sample 320-U1334A-30X-1, $66 \mathrm{~cm}$, and the top of Chiasmolithus grandis in Sample 320-U1334-30X-2, 74 cm. Intriguingly, both species are mid- to high-latitude taxa (Wei and Wise, 1989) and are present only rarely and sporadically at Site U1334. Planktonic foraminifers are present through most of the succession and are relatively abundant and well preserved from the lower Miocene to the lower Oligocene. The lower Miocene is characterized by the presence of Dentoglobigerina spp., Paragloborotalia siakensis-mayeri, Paragloborotalia kugleri, and Paragloborotalia pseudokugleri. Oligocene sediments contain Catapsydrax spp., Paragloborotalia opima-nana, and characteristic Dento- 
globigerina spp. Preservation and abundance of planktonic foraminifers is more variable in the middle Miocene and upper Eocene/lowermost Oligocene. No Eocene/Oligocene boundary marker hantkeninids were identified. Benthic foraminifers are present through most of the section and indicate lower bathyal to abyssal paleodepths.

Sedimentation rates, as derived from magneto- and biostratigraphic age determinations, vary throughout the section and are $\sim 4 \mathrm{~m} / \mathrm{m}$.y. in the topmost sediment cover, vary between $\sim 12$ and $14 \mathrm{~m} / \mathrm{m}$.y. in the lower Miocene through upper lower Oligocene section, increase to $\sim 24 \mathrm{~m} / \mathrm{m}$.y. in the lower Oligocene, and are $\sim 8 \mathrm{~m} / \mathrm{m} . \mathrm{y}$. in the upper Eocene. There is no obvious hiatus in the shipboard biostratigraphic sequence. The presence of all major fossil groups as well as a detailed and well-resolved magnetostratigraphy will allow us to achieve one of the main PEAT objectives of arriving at an integrated Cenozoic stratigraphy and age calibration for major parts of the Miocene, Oligocene, and Eocene.

A full physical property program was run on cores from Site U1334. This program comprises WholeRound Multisensor Logger (WRMSL) measurements of magnetic susceptibility, bulk density, and $P$-wave velocity, along with natural gamma radiation (NGR) and measurements of color reflectance, followed by discrete measurements of moisture and density (MAD) properties, sound velocities, and thermal conductivity in Hole U1334A. All track data are variable throughout the section, allowing a detailed correlation between different holes, with the exception of a very low magnetic susceptibility signal within an interval extending slightly above and below the light greenish gray tinted cores of Unit II (see "Lithostratigraphy" for exact color definitions), between 140 and $205 \mathrm{~m}$ CSF. Magnetic susceptibility varies between $10 \times 10^{-5}$ and $40 \times 10^{-5} \mathrm{SI}$ in Unit I, oscillates around $5 \times 10^{-5}$ to $10 \times 10^{-5}$ SI above the colored sediments, and then drops to near zero and negative values, returning to values around $10 \times 10^{-5} \mathrm{SI}$ in the lower part of Unit II and Subunit IIIa. NGR increases slightly at the Eocene/Oligocene boundary at $246 \mathrm{~m}$ CSF (from 4 to 7 counts per second [cps]). $P$-wave velocity remains uniform through the upper $150 \mathrm{~m}$ of sediment (varying around $1500 \mathrm{~m} / \mathrm{s}$ ) but increases rapidly below the ooze/chalk boundary to $\sim 1600 \mathrm{~m} / \mathrm{s}$. This explains the slightly thicker sediment section than was expected from seismic data prior to coring ( $20 \mathrm{~m}$ thicker). For Hole U1334B, no $P$-wave velocity WRMSL data were collected between $\sim 125$ and $240 \mathrm{~m}$ CSF to allow for a more timely stratigraphic correlation of cores within the iron reductiondominated colored cores with the gamma ray attenuation (GRA) instrument. Bulk density and grain density increase gradually with carbonate content to $\sim 204 \mathrm{~m} \mathrm{CSF}$ to a maximum of $\sim 1.8 \mathrm{~g} / \mathrm{cm}^{3}$ and then show stepped decreases in the lower part of this succession. Ephemeral whole-round samples were collected at $\sim 50$ and $\sim 165 \mathrm{~m}$ for shore-based studies of sediment permeability.

WRMSL data were used to achieve stratigraphic correlation among holes at Site U1334. Magnetic susceptibility was initially the main parameter used for real-time correlation, as a second loop of the susceptibility meter is mounted on the Special Task Multisensor Logger (STMSL); the second bulk density instrument on this track was not working. In the very low (sometimes negative) magnetic susceptibility interval between $\sim 140$ and $\sim 205 \mathrm{~m} \mathrm{CSF}$ (Cores $320-\mathrm{U} 1334 \mathrm{~A}-16 \mathrm{H}$ through $21 \mathrm{H}$ ), the signal was not useful for correlation, and we measured the corresponding cores from Hole U1334B out of sequence to establish the amount of core overlap using bulk density. The coring effort in Hole U1334C was successful at covering gaps between cores at this site to $\sim 111 \mathrm{~m}$ core composite depth below seafloor (CCSFA; see "Core composite depth scale" in the "Methods" chapter), as well as from 250 to 335 m CCSF-A, almost to the bottom of the section. The correlation was challenging between the three holes at Site U1334 in the greenish-light gray interval (Cores 320-U1334A-15H through 22H, 320-U1334B-14B through $22 \mathrm{H}$, and $320-\mathrm{U} 1334 \mathrm{C}-14 \mathrm{H}$ through $22 \mathrm{H}$ ) and in the bottom $80 \mathrm{~m}$ of the section, where $\mathrm{XCB}$ coring compromised the GRA density variations that would otherwise help stratigraphic correlation. Visual inspection, comparison with core imagery, and biostratigraphic datums were used to establish and verify hole to hole correlation where track data lacked clearly identifiable features. Stratigraphic correlation between individual holes indicates a growth factor (ratio between the CCSF-A and CSF depth scales) of $\sim 16 \%$. Stratigraphic correlation resulted in a complete splice through the Eocene-Oligocene transition almost to basement ( $38 \mathrm{Ma})$.

A full range of paleomagnetic analyses was conducted on 66 advanced piston corer (APC) cores and 188 discrete samples from Site U1334 for the APCcored section of Site U1334 (upper $209 \mathrm{~m}$ ). Unlike Sites U1331 and U1332, the drilling overprint was generally weak for Site U1334 cores, but only for those collected with nonmagnetic core barrels (Cores $320-\mathrm{U} 1334 \mathrm{~A}-1 \mathrm{H}$ through $16 \mathrm{H}, 320-\mathrm{U} 1334 \mathrm{~B}-1 \mathrm{H}$ through $15 \mathrm{H}$, and $320-\mathrm{U} 1334 \mathrm{C}-1 \mathrm{H}$ through $15 \mathrm{H})$. In contrast, those cores collected with steel core barrels are highly overprinted. The overprint is so severe that even demagnetization at $20 \mathrm{mT}$ only partially removes it. This extreme overprint notably degrades the paleomagnetic declination data, as can be noted 
by their higher variability, which makes polarity determination much more difficult in the intervals collected with steel core barrels. The problem is exacerbated by the decay in the intensity (and magnetic susceptibility) that occurs at $\sim 135 \mathrm{~m}$ CSF in all three holes as a result of reduction diagenesis. Even within the highly reduced interval, an interpretable signal was present prior to switching to steel core barrels. Magnetic susceptibility in the upper $45 \mathrm{~m}$ of Hole U1334A averages $\sim 18 \times 10^{-5}$ SI (volume normalized) and decreases to a mean of $6 \times 10^{-5} \mathrm{SI}$ from 45 to $135 \mathrm{~m}$ CSF. A notable low occurs from $\sim 140$ to $204 \mathrm{~m}$ CSF, where the average susceptibility is $0.6 \times 10^{-5} \mathrm{SI}$. This low interval is associated with a change in sediment color from yellowish tan to very light green, blue, and gray at $\sim 143 \mathrm{~m} \mathrm{CSF}$ and another abrupt change to reddish brown tones at $\sim 192 \mathrm{~m} \mathrm{CSF}$, which corresponds to middle early Oligocene ( $30 \mathrm{Ma})$. Just below $205 \mathrm{~m}$, magnetic susceptibility steps up to an average of $5 \times 10^{-5} \mathrm{SI}$ and then increases again across the Eocene/Oligocene boundary $(\sim 245 \mathrm{~m})$ to an average of $18 \times 10^{-5} \mathrm{SI}$. The magnetostratigraphy in Hole U1334A has been interpreted from the top of Chron $11 \mathrm{r}(29.957 \mathrm{Ma})$, which occurs $\sim 55 \mathrm{~cm}$ below the top of Section 320-U1334C-21H-4 ( 195 m CSF) through the base of Chron C3n.4n (5.235 Ma) in Core 320U1334A-1H ( 4 m CSF). The youngest sediments recovered are in the upper $\sim 2 \mathrm{~m}$ of Core $320-\mathrm{U} 1334 \mathrm{~A}-$ $1 \mathrm{H}$, which record Chrons C1n through C2r.1r.

A standard shipboard suite of geochemical analyses of pore water and organic and inorganic sediment properties was undertaken on samples from Site U1334. We also conducted a high-resolution (one per section) Rhizon pore water investigation across the interval's middle Oligocene cores (320-U1334C$16 \mathrm{H}$ through $21 \mathrm{H}$ ) that exhibited colored sediments. Site U1334A is marked by alkalinities between 3 and $4 \mathrm{mM}$ throughout. The most striking features in the interstitial water geochemistry are a dissolved manganese peak from $\sim 20$ to $\sim 240 \mathrm{~m}$ CSF with a maximum of $\sim 6 \mu \mathrm{M}$ at $\sim 110 \mathrm{~m}$ CSF and a dissolved iron peak as high as $>15 \mu \mathrm{M}$ centered at $165 \mathrm{~m}$ CSF. The depth range of the dissolved iron peak, indicative of iron oxide reduction, coincides with the colorful interval seen in the lithology and with the interval of low magnetic susceptibilities ( 140-205 m CSF). Sulfate results indicate limited sulfate reduction. Calcium carbonate contents are low in the uppermost $\sim 35 \mathrm{~m}$ of Site U1334, and calcium carbonate contents are generally high ( $\sim 80 \mathrm{wt} \%)$ below the uppermost clay layer.

Wireline logging was attempted in Hole U1334C with a redesigned tool string configuration after the loss of equipment at Site U1332. However, this attempt had to be abandoned after the logging winch failed when the tool was on its way down the drill pipe.

Five downhole temperature measurements were conducted in Hole U1334B with the advanced piston corer temperature tool (APCT-3) tool and reveal a thermal gradient of $33^{\circ} \mathrm{C} / \mathrm{km}$. Seafloor temperature is $\sim 1.5^{\circ} \mathrm{C}$. Temperature data combined with wholeround core temperature conductivity measurements indicate the heat flow is $31.6 \mathrm{~mW} / \mathrm{m}^{2}$ at this site. This is somewhat lower than values obtained for the nearest site (1218).

\section{Highlights}

\section{Eocene-Oligocene and Oligocene-Miocene transitions and depth transects}

Site U1334 was planned as the youngest and shallowest component of the PEAT Eocene-Oligocene depth transect component, which will allow the study of critical intervals (such as the EoceneOligocene transition; see Coxall et al., 2005) and variations of the equatorial CCD. Site U1334 is estimated to have been $\sim 3.5 \mathrm{~km}$ deep during the EoceneOligocene transition, $\sim 1.3 \mathrm{~km}$ shallower than today and $800 \mathrm{~m}$ shallower at that time than Site U1333. Unlike previously drilled sites, the dominant lithology below the Eocene-Oligocene transition is still nannofossil ooze and chalk, with significant amounts of carbonate present. These carbonate amounts will allow us to achieve the prime objective for this site. The Eocene-Oligocene transition, which was cored multiple times at Site U1334, has higher sedimentation rates than previously cored examples. The overlying Oligocene is also much more expanded than at Site 1218, with better preservation of planktonic foraminifers over a longer time interval, permitting a more detailed study of the Oligocene climate system. Site U1334 contains carbonate-bearing sediments across the Oligocene-Miocene transition. Physical property data from Site U1334 can be correlated cycle by cycle to Site 1218, allowing correlation to a previously astronomically calibrated site for the Oligocene.

\section{Geochemical front}

At Site U1334 we recovered a $\sim 50 \mathrm{~m}$ thick interval of light greenish gray carbonates that show a distinct peak in dissolved Fe concentrations, characteristic of a geochemical alteration front. A similar but much thicker alteration zone is also observed at IODP Site U1335 and provides the opportunity to study organic matter degradation while these sites migrate from south to north through the equatorial belts of high productivity. 


\section{Age transect of seafloor basalt}

At Site U1334 we recovered what appear to be fresh fragments of seafloor basalt, aged $\sim 38 \mathrm{Ma}$ as estimated from biostratigraphic results. This material will, when combined with other PEAT basalt samples, provide important sample material for the study of seawater alteration of basalt.

\section{Operations}

\section{Transit to Site U1334}

The $410 \mathrm{nmi}$ voyage from Site U1333 to Site U1334 took $40.8 \mathrm{~h}$ and was accomplished at an average speed of $10.1 \mathrm{kt}$. During the transit the ship's clocks were advanced $1 \mathrm{~h}$, resetting local ship time to more closely follow the earlier rising sun as we migrated eastward to each site. Times for Site U1334 are given in ship local time (UTC -9 h).

\section{Site U1334}

\section{Hole U1334A}

Once the vessel approached the coordinates of the new location, the captain slowed the vessel and maneuvered the vessel over the site. We were positioning over the new location by $1222 \mathrm{~h}$ on 6 April 2009 . After assembling the drill string and lowering it to the seafloor, we attempted to spud the new site with the bit positioned $10 \mathrm{~m}$ shallower than the corrected depth of $4798.4 \mathrm{~m}$ drilling depth below rig floor (DRF) $(4787.0 \mathrm{mbsl})$ from the precision depth recorder (PDR). We recovered only water, so the bit was lowered to $4798 \mathrm{~m}$ DRF for a second attempt. This was successful, and Hole U1334A was spudded with the APC at $0030 \mathrm{~h}$ on 7 April. The mudline recovered in Core $1 \mathrm{H}$ was used to establish the seafloor depth as $4799.3 \mathrm{~m}$ DRF (4787.9 mbsl) (Table T1). This depth was within $1 \mathrm{~m}$ of the corrected PDR depth.

APC Cores $1 \mathrm{H}$ through $22 \mathrm{H}$ were taken from 0 to $206.9 \mathrm{~m}$ DSF, and we recovered $212.39 \mathrm{~m}$ (103\%) (Table T1). APC coring was terminated when Core $22 \mathrm{H}$ did not stroke fully and required $80,000 \mathrm{lb}$ to release it from the formation. Nonmagnetic core barrels were used on Cores $1 \mathrm{H}$ through $16 \mathrm{H}$; standard steel core barrels were used on Cores $17 \mathrm{H}$ through $22 \mathrm{H}$.

XCB Cores 23X through 32X were taken from 206.9 to $285.5 \mathrm{~m}$ DSF, and we recovered $77.99 \mathrm{~m}$ (99\%). Coring was terminated when we recovered basalt in Core $32 \mathrm{X}$. The total cored interval for Hole U1334A was $285.5 \mathrm{~m}$, and we recovered $288.83 \mathrm{~m}(102 \%)$. The drill string was pulled out of the hole and cleared the seafloor at $2150 \mathrm{~h}$ on 8 April.

\section{Hole U1334B}

The ship was offset $25 \mathrm{~m}$ west of Hole U1334A, and we spudded Hole U1334B at 2330 h on 8 April 2009 with the bit $5 \mathrm{~m}$ deeper than at the first hole. APC Cores $1 \mathrm{H}$ through $22 \mathrm{H}$ were taken from 3.7 to $210.7 \mathrm{~m}$ DSF, and we recovered $218.43 \mathrm{~m}$ (105\%). Nonmagnetic core barrels were used on Cores $1 \mathrm{H}$ through $15 \mathrm{H}$, and standard steel barrels were used on Cores $16 \mathrm{H}$ through $22 \mathrm{H}$. Downhole temperature measurements were obtained at 32.2, 49.2, 68.2, 87.2, and $106.2 \mathrm{~m}$ DSF (Cores 3H, 5H, 7H, 9H, and $11 \mathrm{H}$, respectively). Core $5 \mathrm{H}$ was advanced $7.5 \mathrm{~m}$ to maintain an $\sim 5$ m vertical offset with Hole U1334A.

XCB Cores 23X through 31X were taken from 207.0 to $281.7 \mathrm{~m}$ DSF, and we recovered $76.84 \mathrm{~m} \mathrm{(103 \% ).}$ We stopped coring when we recovered basalt in Core $31 \mathrm{X}$. We pulled the drill string out of the hole and the bit cleared the seafloor at $1840 \mathrm{~h}$ on 10 April.

\section{Hole U1334C}

After the ship was offset $25 \mathrm{~m}$ west of Hole U1334B, Hole U1334C was spudded at $2020 \mathrm{~h}$ on 10 April 2009 with the bit $3 \mathrm{~m}$ deeper than Hole U1334A. APC Cores $1 \mathrm{H}$ through $22 \mathrm{H}$ penetrated from 0 to $209.0 \mathrm{~m}$ DSF, and we recovered $213.0 \mathrm{~m} \mathrm{(102 \% ).}$ Nonmagnetic core barrels were used on Cores $1 \mathrm{H}$ through $15 \mathrm{H}$; Cores $16 \mathrm{H}$ through $22 \mathrm{H}$ used standard steel barrels. We had to drillover Cores $19 \mathrm{H}, 21 \mathrm{H}$, and $22 \mathrm{H}$ to release them from the formation. We then switched to $\mathrm{XCB}$ coring. Cores $23 \mathrm{X}$ through $33 \mathrm{X}$ were taken from 209.0 to $280.7 \mathrm{~m}$ DSF, and we recovered $72.9 \mathrm{~m}(102 \%)$. Core 26X was advanced by $6 \mathrm{~m}$ to maintain stratigraphic overlap with the first two holes. Coring finished when limestone including basalt clasts was recovered in the last core. Cores from Hole U1334C successfully covered the stratigraphic gaps in the first two holes.

Our final operations planned for Hole U1334C were to conduct two downhole logging runs. We circulated the hole with $50 \mathrm{bbl}$ of attapulgite mud and then displaced the hole with $100 \mathrm{bbl}$ of attapulgite mud. We raised the bit up to $95 \mathrm{~m}$ DSF and rigged up for logging. The first tool string was assembled and deployed into the pipe at $1930 \mathrm{~h}$ on 12 April. While lowering the logging tool string into the hole, the transmission on the logging winch failed when the tool was $\sim 1700 \mathrm{~m}$ below the rig floor. We started to manually retrieve the tool string using T-bar clamps, air tuggers, and the starboard crane. After recovering $\sim 550 \mathrm{~m}$ of wireline and spooling it back onto the logging winch drum, we decided to retrieve the remaining logging wireline by spooling the logging wireline onto the core winch drum. The logging tool was back on the rig floor at $\sim 1200 \mathrm{~h}$ on 13 April. No 
more logging could be conducted during Expedition 320.

We started pulling the drill string out of the hole and the bit cleared the seafloor at $1225 \mathrm{~h}$ on 13 April. After the drill string was recovered and the thrusters retracted, we began the transit for Site U1335 at $2200 \mathrm{~h}$ on 13 April.

\section{Lithostratigraphy}

Drilling at Site U1334 recovered an $\sim 285 \mathrm{~m}$ thick section of pelagic sediments overlying seafloor basalt (Fig. F5). The sedimentary sequence at Site U1334 is divided into four major lithologic units (Fig. F5; Table T2). The top of the section (0-47 m CSF) is an early to middle Miocene clay intercalated with nannofossil and radiolarian oozes (Unit I). The topmost $15 \mathrm{~m}$ interval of Unit I consists predominantly of radiolarian clay with varying amounts $(<15 \%)$ of micronodules and zeolite. These sediments overlie alternations of radiolarian clay and nannofossil ooze. Unit II consists of $\sim 200 \mathrm{~m}$ of early Miocene to Oligocene nannofossil ooze and chalk overlying a $\sim 35 \mathrm{~m}$ thick alternating sequence of late Eocene nannofossil chalk, radiolarite, and claystone (Unit III). A thin layer ( $1 \mathrm{~m}$ thick) of middle Eocene micritic chalk and limestone was recovered at the base of the sedimentary sequence (Unit IV) above basement basalt.

Lithologic units and boundaries are defined by differences in lithology, physical property data series, and calcium carbonate $\left(\mathrm{CaCO}_{3}\right)$ content as measured by coulometry. Lithologic differences, based on both visual core description and smear slide analysis, are primarily attributable to varying distributions of biogenic components such as nannofossils, radiolarians, and diatoms and clay-sized lithogenic material (Fig. F5; see "Site U1334 smear slides" in "Core descriptions"). Lithologic descriptions are based primarily on sediments recovered in Hole U1334A, supplemented with observations from Holes U1334B and U1334C.

\section{Unit I}

Intervals: $320-\mathrm{U} 1334 \mathrm{~A}-1 \mathrm{H}-1,0 \mathrm{~cm}$, through $5 \mathrm{H}-$ CC, $25 \mathrm{~cm}$; 320-U1334B-1H-1, $0 \mathrm{~cm}$, through $5 \mathrm{H}-3,55 \mathrm{~cm}$; 320-U1334C-1H-1, $0 \mathrm{~cm}$, through $5 \mathrm{H}-1,65 \mathrm{~cm}$

Depths: Hole U1334A $=0.0-46.76$ m CSF; Hole $\mathrm{U} 1334 \mathrm{~B}=0.0-45.25 \mathrm{~m}$ CSF ; Hole U1334C $=0.0$ $38.7 \mathrm{~m} \mathrm{CSF}$

Age: early to middle Miocene

Lithology: clay, radiolarian clay, clayey radiolarian ooze, and nannofossil ooze
The major lithologies in Unit I are light yellowish brown (10YR 6/4) to very dark brown (10YR 3/2) to very dark gray (10YR 3/1) clay, dark grayish brown (10YR 4/2) to very dark grayish brown (10YR 3/2) radiolarian clay, brown (10YR 4/3) radiolarian ooze, and very pale brown to brown (10YR $8 / 2$ to $10 \mathrm{YR}$ $5 / 3$ ) nannofossil ooze. Clay occurs with minor amounts of zeolites and micronodules, as well as radiolarians and nannofossils. Radiolarian ooze occurs with minor amounts of clay or nannofossils. Nannofossil ooze sometimes occurs with radiolarians or clay. The uppermost 2 to $5 \mathrm{~m}$ of the unit is composed of clay with significant amounts of zeolites and micronodules (up to 15\%). Radiolarian clay dominates to $15 \mathrm{~m}$ CSF, below which radiolarian clay and clayey radiolarian ooze alternate with nannofossil ooze. The transition from the topmost interval of clayey sediments to the underlying clay/ nannofossil ooze alternations is characterized by an increase in the amplitude of variations and absolute values in magnetic susceptibility, gamma ray attenuation (GRA) bulk density and color reflectance $\left(b^{*}\right.$ and L* shown) (Fig. F5; see "Physical properties" for discussion of reflectance, including $\left.\mathrm{a}^{*}\right) . \mathrm{CaCO}_{3}$ contents are near zero at the top of Unit I and highly variable where clays and nannofossil oozes alternate. The transition to Unit II is indicated by the increased importance of biogenic oozes relative to clay and a marked shift in physical properties, including a decrease in magnetic susceptibility, an increase in GRA bulk density, and an increase in $\mathrm{L}^{*}$ (Fig. F5).

\section{Unit II}

Intervals: 320-U1334A-6H-1, $0 \mathrm{~cm}$, through $27 \mathrm{X}-2$, $26 \mathrm{~cm}$; 320-U1334B-5H-3, $55 \mathrm{~cm}$, through 26X$4,124 \mathrm{~cm} ; 320-\mathrm{U} 1334 \mathrm{C}-5 \mathrm{H}-1,65 \mathrm{~cm}$, through 27X-6, $96 \mathrm{~cm}$

Depths: Hole U1334A = 46.76-244.96 m CSF; Hole $\mathrm{U} 1334 \mathrm{~B}=45.25-243.94 \mathrm{~m}$ CSF; Hole U1334C = 38.7-247.66 m CSF

Age: early Miocene to late Eocene

Lithology: nannofossil ooze, nannofossil ooze with radiolarians, and nannofossil chalk

The dominant lithology in Unit II is white (10YR 8/1) to very pale brown (10YR 8/2, 10YR 8/3, 10YR 7/3, and 10YR 7/4) nannofossil ooze with an exceptional $65 \mathrm{~m}$ thick interval of greenish and yellowish nannofossil ooze (Figs. F5, F7). Between 141 and 206 m CSF (Hole U1334A) sediment color undergoes a downhole transition from pale yellow $(5 \mathrm{Y} 8 / 2)$ to several shades of light greenish gray (10Y 8/1, 10G 8/1, and 5 BG 8/1), light gray (N7), and back again through pale yellow $(2.5 \mathrm{Y} 8 / 2)$ before returning to very pale brown (10YR 8/3). Bioturbation is generally minor throughout the unit. Nannofossil ooze some- 
times includes radiolarians and clay as minor lithologic components. The alteration of relatively pure nannofossil oozes and nannofossil ooze with radiolarians or with clay creates subtle color banding on scales 20 to $80 \mathrm{~cm}$ thick (Fig. F8). Unit II sediments have $\mathrm{CaCO}_{3}$ contents that are typically near $90 \mathrm{wt} \%$ (Fig. F5; see "Geochemistry"). L* and GRA bulk densities are elevated throughout Unit II ( 90 and $<1.6 \mathrm{~g} / \mathrm{cm}^{3}$, respectively), whereas magnetic susceptibility remains low (typically $<15 \times 10^{-6} \mathrm{SI}$ ). The interval of light greenish gray nannofossil ooze between 143 and 191 m CSF (Hole U1334A) is associated with a pronounced decrease in $\mathrm{b}^{*}$ but little change in $\mathrm{L}^{*}$ (Figs. F5, F7). Magnetic susceptibility is exceptionally low, approaching zero and sometimes below zero, throughout the greenish and yellowish intervals between 141 and 206 m CSF (Figs. F5, F7; see "Physical properties" and "Geochemistry").

\section{Unit III}

Intervals: 320-U1334A-27X-2, $26 \mathrm{~cm}$, through $31 \mathrm{X}-2,25 \mathrm{~cm}$; 320-U1334B-26X-4, $124 \mathrm{~cm}$, through 31X-5, $30 \mathrm{~cm}$; 320-U1334C-27X-6, $96 \mathrm{~cm}$, through $31 \mathrm{X}-2,40 \mathrm{~cm}$

Depths: Hole U1334A = 244.96-283.55 m CSF; Hole U1334B = 243.94-282.90 m CSF; Hole $\mathrm{U} 1334 \mathrm{C}=247.66-279.41 \mathrm{~m}$

Age: middle to late Eocene

Lithology: nannofossil chalk, clayey nannofossil chalk, and clayey radiolarite

The dominant lithologies in Unit III are very pale brown (10YR 8/1 and 10YR 7/3) to light gray (10YR $7 / 2$ ) to light yellowish brown (10YR 6/4) nannofossil chalk with lesser amounts of very dark brown (10YR $2 / 2$ ) and very dark grayish brown (10YR 3/2) clayey nannofossil chalk and brown (10YR 5/3 and 10YR 4/3) nannofossil chalk with clay and very dark grayish brown (10YR 3/2) clayey radiolarite. Within the major lithologies, nannofossil chalk occurs with radiolarians and clay as minor lithologic components. The Unit II-III transition is identified by an increase in clay and radiolarian contents relative to nannofossils, an increase in magnetic susceptibility, and a decrease in GRA bulk density, $\mathrm{L}^{*}$ and $\mathrm{b}^{*}$ reflectance, and $\mathrm{CaCO}_{3}$ contents (Fig. F5).

\section{Unit IV}

Intervals: $320-\mathrm{U} 1334 \mathrm{~A}-31 \mathrm{X}-2,25 \mathrm{~cm}$, through at least 32X-CC, $40 \mathrm{~cm} ; 320-\mathrm{U} 1334 \mathrm{~B}-31 \mathrm{X}-5,30 \mathrm{~cm}$, through at least $31 \mathrm{X}-\mathrm{CC}, 9 \mathrm{~cm} ; 320-\mathrm{U} 1334 \mathrm{C}-$ $31 \mathrm{X}-2,40 \mathrm{~cm}$, through at least 32X-CC, $43 \mathrm{~cm}$

Depths: Hole U1334A = 283.55-285.40 m CSF; Hole U1334B = 282.90-283.99 m CSF; Hole $\mathrm{U} 1334 \mathrm{C}=279.41-280.13 \mathrm{~m} \mathrm{CSF}$

Age: middle Eocene
Lithology: micritic nannofossil chalk and limestone The major lithologies in Unit IV are very pale brown (10YR 8/2) micritic nannofossil chalk and very pale brown (10YR 7/4) to brown (10YR 5/4) nannofossil chalk and white limestone. Unit IV is distinguished from Unit III by the presence of micrite as a major component in nannofossil chalk and of limestone.

\section{Unit V}

Intervals: $320-\mathrm{U} 1334 \mathrm{~A}-32 \mathrm{X}-\mathrm{CC}, 40 \mathrm{~cm}$, to at least $32 \mathrm{X}-\mathrm{CC}, 43 \mathrm{~cm}$; 320-U1334B-31X-CC, $9 \mathrm{~cm}$, to at least 31X-CC, $11 \mathrm{~cm} ; 320-\mathrm{U} 1334 \mathrm{C}-32 \mathrm{X}-\mathrm{CC}$, $43 \mathrm{~cm}$, to at least 32X-CC, $49 \mathrm{~cm}$

Depths: Hole U1334A $=285.40$ to at least $285.43 \mathrm{~m}$ CSF; Hole U1334B $=283.99$ to at least $284.01 \mathrm{~m}$ CSF; Hole U1334C $=280.13$ to at least $280.19 \mathrm{~m}$ $\mathrm{CSF}$

Several broken pieces of basalt up to $10 \mathrm{~cm}$ in length were recovered at the base of each hole at Site U1334. Basalt is either intercalated with or overlain by the micritic chalks and limestone of Unit IV.

\section{Redox related color changes}

The relatively homogeneous lithology of Unit II is marked by vivid color changes that are made obvious against the backdrop of relatively white nannofossil oozes. Sediment color shifts downhole from white (10YR 8/1) to very pale brown (10YR 8/2) to pale yellow (2.5Y 8/1) to light greenish gray (10GY $8 / 1$ ) over a $65 \mathrm{~m}$ thick interval and persists as light greenish gray for $\sim 40 \mathrm{~m}$ before returning back through pale yellow to very pale brown and white (Fig. F7). Reflectance parameters $a^{*}$ and $b^{*}$, which measure green-red and blue-yellow portions of the spectrum, respectively, shift in a steplike manner to lower values or toward green $\left(a^{*}\right)$ and blue $\left(b^{*}\right)$ with these observed color changes (Fig. F7). Magnetic susceptibility drops to near zero throughout the light greenish gray interval. Dissolved Fe and Mn concentrations in pore fluids increase 5 to $6 \mu \mathrm{M} / \mathrm{L}$ within these sediments from background concentration of close to zero (see "Geochemistry"). Together with the loss of magnetic signal (see "Paleomagnetism"), the increase in dissolved $\mathrm{Fe}$ concentrations and changes in sediment color indicate intensified microbial Fe reduction, perhaps fueled by higher organic carbon accumulation rates across this interval relative to the under- and overlying nannofossil ooze at Site U1334.

\section{Light-dark color cycles within Oligocene nannofossil oozes}

Readily observable but subtle color variations are common within the very pale brown nannofossil 
oozes of Unit II. These meter-scale light-dark cycles are associated with minor variations in the relative amounts of minor lithologic components, including clay, radiolarians, and diatoms (Fig. F8), and also in physical properties including $\mathrm{L}^{*}, \mathrm{~b}^{*}$, magnetic susceptibility, and GRA bulk density (Fig. F5; see "Physical properties"). Nannofossils dominate the sediments, making up $>95 \%$ of the fine fraction observed in smear slides. The remaining 5\% is dominated by clay, radiolarians, and diatoms. The lithology name remains nannofossil ooze across these slight but apparent variations. The seemingly small shifts in nannofossil contributions, however, often between 95\% and 99\%, are necessarily associated with an approximately two-fold increase in clay or radiolarian content.

\section{Sediments across the Oligocene-Miocene transition}

The Oligocene/Miocene boundary was recovered in all three holes drilled at Site U1334 (Fig. F9). The Oligocene/Miocene boundary is defined by the appearance of the planktonic foraminifer $P$. kugleri $(23.0 \mathrm{Ma})$ and approximated well by the short-lived ( 100 k.y.) calcareous nannofossil Sphenolithus delphix (23.1-23.2 Ma), just below C6Cn.2n. P. kugleri is present in Sample 320-U1334A-10H-2, 38-40 cm, but not in Sample $10 \mathrm{H}-5,38-40 \mathrm{~cm}$, placing the midpoint of this datum in Core 320-U1334A-10H-3 (Fig. F9; see "Biostratigraphy"). The base of Chron C6Cn.2n, the magnetostratigraphic Oligocene/ Miocene marker, however, locates the boundary 2 to $6 \mathrm{~m}$ lower, around interval 320-U1334A-10H-6, $100 \mathrm{~cm}$. S. delphix is identified between intervals $320-\mathrm{U} 1334 \mathrm{~A}-10 \mathrm{H}-7,30 \mathrm{~cm}$, and $11 \mathrm{H}-2,20 \mathrm{~cm}$, consistent with the magnetostratigraphic data.

The Oligocene-Miocene transition in Hole U1334A occurs in very pale brown nannofossil ooze with subtle light (10YR 8/2) and dark (10YR 7/4) color alternations. Four darker (10YR 7/4) layers alternating with lighter ones are evident upsection of the Oligocene/Miocene boundary in Hole U1334A (Fig. F9). The same alternating sequence is also observed above the Oligocene-Miocene transition in Cores 320-U1334B-9H and 320-U1334C-9H (Fig. F9). Smear slide observations do not show significant differences in constituents between dark and light layers, but compositional variations are indicated by variations of GRA bulk density, $\mathrm{L}^{*}$, and magnetic susceptibility that accompany the color changes (Fig. F9). A similar pattern in magnetic susceptibility is identified in Holes U1334B and U1334C (Fig. F9) and at Site 1218 (Shipboard Scientific Party, 2002b; Pälike et al., 2005).

\section{Sediments across the Eocene-Oligocene transition}

An Eocene-Oligocene transition section was recovered in all three holes drilled at Site U1334 (Holes U1334A-U1334C) (Figs. F5, F10). The Eocene/ Oligocene boundary marker, Hantkenina species, has not been found at Site U1334 (see "Biostratigraphy"). However, radiolarian and nannofossil biostratigraphy provide excellent age control, indicating that the Eocene/Oligocene boundary falls near the middle of Biozone NP21 and just above the Zone RP20/RP19 boundary (near the base of Core 320-U1334A-27X, in the upper part of Core 320U1334B-26X, and toward the lower part of Core 320-U1334C-27X) (Fig. F10).

The lithostratigraphy of the Eocene-Oligocene transition is well captured in all three holes drilled at Site U1334. In Hole U1334B, starting in Core 320U1334B-26X, a downhole transition takes place from light gray (10YR 7/2) nannofossil ooze to dark brown (10YR 3/3) clayey nannofossil chalk (Figs. F10, F11), and these sediments overlie an alternating sequence of grayish brown (10YR 5/2) nannofossil chalk and very dark grayish brown (10YR 3/2) clayey nannofossil chalk with an underlying prominent $(\sim 60 \mathrm{~cm}$ thick) bed of very dark brown (10YR 2/2) radiolarian clay in Section 320-U1334B-27X-5 (Figs. F10, F11). Similar downhole lithologic transitions are seen in Holes U1334A and U1334C (Fig. F10). Thus, the Eocene-Oligocene transition at Site U1334 is marked by a distinct stepwise downhole color change from pale nannofossil ooze through dark clayey nannofossil chalk to alternations of dark nannofossil chalk and even darker clayey nannofossil chalk. Magnetic susceptibility, $\mathrm{a}^{*}$, and $\mathrm{b}^{*}$ display pronounced downhole stepwise increases with pronounced downhole deceases in GRA bulk density, $\mathrm{L}^{*}$, and $\mathrm{CaCO}_{3}$ content (Figs. F5, F10; see "Physical properties").

The lithostratigraphic results for the EoceneOligocene transition at Site U1334 are broadly consistent with those at Sites U1331-U1333 and multiple sites drilled during ODP Leg 199, in particular, Site 1218 (see the "Site U1331," "Site U1332," and "Site U1333" chapters) (Shipboard Scientific Party, 2002a). The most obvious lithostratigraphic difference between the Eocene-Oligocene transition at Sites U1334 and U1333 is that the transition at Site U1334 takes place within sediments that are significantly darker in color ( $L^{*}$ values up to $60 \%$ at Site U1334 and up to $80 \%$ at Site U1333) (Fig. F12). The darker sediments at Site U1334 correspond to a more calcareous lithologic sequence and higher $\mathrm{CaCO}_{3}$ contents than the darker Eocene sediments at Site U1333 (compare Fig. F5 in this chapter with Fig. F4 
in the "Site U1333" chapter) (Fig. F12). The darker Eocene-Oligocene transition at Site U1334 is therefore attributed to higher clay content than at Site U1333, as indicated by magnetic susceptibility records for the two sites (Site U1334 = up to $60 \times 10^{-5}$ SI units; Site U1333 = up to $40 \times 10^{-5}$ units) (Fig. F12).

\section{Summary}

At Site U1334, Eocene seafloor basalt is overlain by about $285 \mathrm{~m}$ of pelagic sediments that are divided into four major lithologic units. Sediments are dominated by nannofossil oozes and nannofossil chalks. The early Miocene sedimentary sequence contains more clay and radiolarians relative to the Oligocene and Eocene sediments. The near-white Oligocene nannofossil oozes are characterized by both subtle meter-scale dark-light color cycles and vivid color variations that take place over $60 \mathrm{~m}$. The subtle color cycles are the manifestation of small changes in the relative proportions of lithologic components, namely radiolarians, clay, and diatoms. The more vivid color cycles are related to changes in the oxidation state of $\mathrm{Fe}$ in the sediments and sedimentary pore waters. The oxidation-reduction reactions responsible for the observed color and pore water chemistry changes are likely fueled by enhanced availability of organic carbon relative to overlying and underlying sediments. The Oligocene-Miocene transition at Site U1334 is characterized by four subtle light-dark color alternations in very pale brown nannofossil ooze. The Eocene-Oligocene transition at Site U1334 is marked by a distinct stepwise color change from pale nannofossil ooze to dark clayey nannofossil chalk to alternations of dark nannofossil chalk and even darker clayey nannofossil chalk. Compared to Site U1333, the Eocene-Oligocene transition at Site U1334 takes place in significantly darker sediments. This observation is attributed to higher clay content, indicated by the higher values in the magnetic susceptibility record for Site U1334.

\section{Biostratigraphy}

At Site U1334, we recovered a $285 \mathrm{~m}$ thick succession of middle Miocene to uppermost middle Eocene nannofossil ooze and radiolarian clays with nannofossils. The uppermost $12 \mathrm{~m}$ of brown clay is barren of calcareous microfossils but contains radiolarians of middle Miocene age. Nannofossil ooze and radiolarian clays occur in the Miocene and Eocene parts of the section, with nannofossil ooze dominant in the thick Oligocene sequence. Radiolarians are present through most of the section, apart from the lowermost cores, and are well preserved in the Eocene.
They provide a coherent high-resolution biochronology, and there appears to be a complete sequence of radiolarian zones from Zones RN7 (middle Miocene) to RP17 (uppermost middle Eocene). Calcareous nannofossils are present and moderately to well preserved through most of the succession, and there appears to be a complete sequence of nannofossil zones from Zone NN6 (middle Miocene) to upper Zone NP17 (uppermost middle Eocene). Nannofossil zonal determinations agree well with the radiolarian biostratigraphy; an integrated calcareous and siliceous microfossil biozonation is shown in Figure F13. A detailed age-depth plot including biostratigraphic and paleomagnetic datums is shown in Figure F14. Planktonic foraminifers are present through most of the succession and are relatively abundant and well preserved from the lower Miocene to the lower Oligocene. The preservation and abundance of planktonic foraminifers is more variable in the middle Miocene and upper Eocene to lowermost Oligocene. Benthic foraminifers are present through most of the section and indicate lower bathyal to abyssal paleodepths.

\section{Calcareous nannofossils}

Calcareous nannofossil biostratigraphy is based on analysis of core catcher samples from all three holes and from samples from most core sections of Hole U1334A. Depth positions and age estimates of biostratigraphic marker events are shown in Table T3. Nannofossils are generally abundant and moderately to well preserved throughout. Distinct intervals of poor nannofossil preservation are associated with dark lithologies within light-dark cycles around the early/middle Miocene boundary (Cores 320-U1334A$4 \mathrm{H}$ through $6 \mathrm{H}$ ) and the Oligocene/Miocene boundary (Cores 320-U1334A-9H through 12H). Nannofossils are also less abundant and less well preserved in the low carbonate interval immediately below the Eocene/Oligocene boundary (Cores 320-U1334A-27H and $28 \mathrm{H}$ ).

The uppermost interval of the succession, from Samples $320-\mathrm{U} 1334 \mathrm{~A}-1 \mathrm{H}-1,100 \mathrm{~cm}$, to $2 \mathrm{H}-3,70 \mathrm{~cm}$, is barren of nannofossils. The first moderately well preserved nannofossil assemblages, between Samples $320-\mathrm{U} 1334 \mathrm{~A}-2 \mathrm{H}-6,120 \mathrm{~cm}$, and $3 \mathrm{H}-4,50 \mathrm{~cm}$, are assigned to the mid to lower part of Neogene Zone NN6 (middle Miocene) based on the presence of Coronocyclus nitescens and Calcidiscus premacintyrei and the absence of Sphenolithus heteromorphus. The top common occurrence of Cyclicargolithus floridanus (lowermost Zone NN6) is recognized in Sample 320-U1334A-3H-3, $50 \mathrm{~cm}$, followed by the top of $S$. heteromorphus (top of Zone NN5) in Sample 320U1334A-3H-5, $50 \mathrm{~cm}$, which suggests continuous 
deposition through this interval. Nannofossil Zones NN4 and NN5 cannot be differentiated in this succession because of the absence of the zonal marker Helicosphaera ampliaperta; however, the presence of Discoaster petaliformis between Samples 320-U1334A$3 \mathrm{H}-5,50 \mathrm{~cm}$, and $3 \mathrm{H}-\mathrm{CC}$ indicates an age of upper Zone NN4 to NN5 (Young, 1999; Raffi et al., 2006). The base of $D$. petaliformis has been calibrated at 15.70 Ma at ODP Sites 925 and 926 (Discoaster signus in Raffi et al., 2006) and at this site occurs in Sample $320-U 1334 \mathrm{~A}-3 \mathrm{H}-\mathrm{CC}$. This is followed by the intraZone NN4 datum top common Discoaster deflandrei in Sample 320-U1334A-4H-2, 70 cm.

Calcareous nannofossils are generally poor to moderately well preserved within Cores 320-U1334A-4H and $5 \mathrm{H}$, and because of the absence of Sphenolithus belemnos, probably due to poor preservation, the base of Zone NN4 cannot be distinguished. Nannofossil preservation improves and abundance increases just below the top of Triquetrorhabdulus carinatus in Sample 320-U1334A-5H-4, $120 \mathrm{~cm}$, which marks the base of Zone NN3. The base of Discoaster druggii occurs in Sample 320-U1334A-9H-CC, marking the base of Zone NN2, but this species is only sporadically distributed in Cores 320-U1334A-5H through 9H. Supplementary biostratigraphic events in this Zone NN1-NN2 interval are the top of the T. carinatus acme event (Raffi et al., 2006) in Sample 320U1334A-9H-CC, the base of Sphenolithus disbelemnos in Sample 320-U1334A-8H-CC, and the top and base of $S$. delphix, which are present in Samples 320U1334A-10H-CC and $11 \mathrm{H}-1,20 \mathrm{~cm}$, respectively. The top of $S$. delphix occurs just prior to the Oligocene/ Miocene boundary.

The Oligocene succession is dominated by white nannofossil oozes with abundant nannofossils that are moderately to well preserved. Initial nannofossil biostratigraphy indicates that this is a complete Oligocene sequence with consistently high sedimentation rates ( $15 \mathrm{~m} / \mathrm{m}$.y.). The top of Zone NP25 is recognized by the top of Sphenolithus ciperoensis in Sample 320-U1334A-12H-CC. The intra-Zone NP24 abundance crossover from Triquetrorhabdulus longus to T. carinatus occurs between Samples 320-U1334A$12 \mathrm{H}-\mathrm{CC}$ and $12 \mathrm{H}-7,30 \mathrm{~cm}$, and the top of Cyclicargolithus abisectus in Sample 320-U1334A-13H-1, $45 \mathrm{~cm}$. The presence of all three sphenolith species, $S$. ciperoensis, Sphenolithus distentus, and Sphenolithus predistentus, in Sample 320-U1334A-16H-CC indicates Zone NP24 age and is also the base of consistent and common $S$. ciperoensis and the top of $S$. distentus and $S$. predistentus. Zones NP24-NP21 are recognized using the base of $S$. ciperoensis in Sample 320-U1334A-18HCC; the top of Reticulofenestra umbilicus in Sample $320-\mathrm{U} 1334 \mathrm{~A}-25 \mathrm{X}-1,80 \mathrm{~cm}$; and the top of Coccoli- thus formosus in Sample 320-U1334A-26X-3, $100 \mathrm{~cm}$. The base of $S$. distentus is an intra-Zone NP23 datum and occurs in Sample 320-U1334A-21H-CC.

The age-depth plot for Site U1334 (Fig. F14) suggests that there is a calibration problem with the $S$. ciperoensis datums. The base of $S$. ciperoensis is difficult to locate because of rare and sporadic occurrences through its lower range followed by a distinct but short abundance peak near the tops of $S$. distentus and $S$. predistentus. The calibration of $27.1 \mathrm{Ma}$ (Blaj et al., 2009) appears to be coincident with the base of the abundance peak and not its full range, which appears to be $\sim 1 \mathrm{~m}$.y. older and closer to the calibration used during Leg 199 (28.1 Ma) (Lyle, Wilson, Janecek, et al., 2002; see discussion in Wei and Wise, 1989).

The Eocene/Oligocene boundary interval lies between the top of $C$. formosus and the top of Discoaster saipanensis, which occurs in Sample 320-U1334A27X-CC. The boundary interval yields nannofossils throughout and is apparently complete at the resolution provided by the nannofossil biostratigraphy. Eocene nannofossil Zones NP19-NP20 through NP17 are recognized using the base of Isthmolithus recurvus in Sample 320-U1334A-29X-CC, base of C. oamaruensis in Sample 320-U1334A-30X-1, $66 \mathrm{~cm}$, and top of C. grandis in Sample 320-U1334A-30X-2, $74 \mathrm{~cm}$. Both $I$. recurvus and C. oamaruensis are mid- to highlatitude taxa (Wei and Wise, 1989) and are present only rarely and sporadically at Site U1334. The presence of Dictyococcites bisectus to the base of the section indicates that the oldest sediment is between 37.1 and 38.0 Ma (upper Zone NP17).

\section{Radiolarians}

The radiolarian stratigraphy at Site U1334 (Fig. F14; Table T4) spans the interval from Zone RN7 (upper Miocene) in the base of Core 320-U1334-1H to the uppermost part of Zone RP17 (middle Eocene) in Sample 320-U1334-30X-2, 120-122 cm (Tables T5, T6, T7). The upper part of the first core (Samples 320-U1334A-1H-2, 105-107 cm, and 1H-4, 105$107 \mathrm{~cm}$ ) recovered poorly preserved, reworked older radiolarians of Oligocene through early Miocene age. No reliable age determination could be made for these samples; however, the youngest species identified was Calocycletta costata (last occurrence at 14.23 $\mathrm{Ma}$ ). In the Miocene through Oligocene interval, the radiolarian assemblage contains traces of reworked older microfossils, particularly in the upper Oligocene sediments (Zone RP21; Cores 320-U1334-10H, $11 \mathrm{H}$, and $16 \mathrm{H}$ through $21 \mathrm{H}$ ). Reworked older radiolarians are also found in the uppermost Eocene interval (Zone RP19; Cores 320-U1334A-27X and 28X). Radiolarians are usually moderately well preserved, 
but intervals of poor preservation are found in the uppermost part of the section (Zones RP5-RP7; Cores $320-\mathrm{U} 1334 \mathrm{~A}-1 \mathrm{H}$ through $3 \mathrm{H}$ ), as well as in parts of the upper Oligocene (Zone RP21; Cores 320-U1334A$17 \mathrm{H}$ through $20 \mathrm{H}$ ). As in all other sites, the lowermost Oligocene (lower part of Zone RP20; Cores $320-U 1334 \mathrm{~A}-23 \mathrm{X}$ through $26 \mathrm{X}$ ) contain common to abundant diatom frustules in the $>63 \mu \mathrm{m}$, acidtreated fraction.

The Eocene section is indurated and the contained radiolarians are encrusted with clay and reprecipitated silica. Cleaning with a strong base solution $(45 \% \mathrm{KOH})$ removed most of the encrustation and allowed the reliable identification of species, even for samples in which the microfossils were fragmented and poorly preserved (Samples 320-U1334A-27XCC, 28X-2, 126-127 cm, 28X-CC, 29X-2, 50-52 cm, and 30X-2, 120-122 cm). Below Sample 320U1334A-30X-2, 120-122 cm, sediments are barren of radiolarians.

\section{Diatoms}

Diatoms were examined in core catcher samples, as well as other samples obtained from Holes U1334A and U1334B. The interval examined represents the Craspedodiscus coscinodiscus Zone and the Rossiella fennerae through Coscinodiscus excavatus Zones of Barron $(1985,2006)$ and Barron et al. (2004). Diatoms range in abundance from rare to abundant depending on the specific sample. Diatom preservation is variable but generally moderate. Diatoms are typically absent or are rare in the core catcher samples from the upper eight cores. The exceptions are Samples 320-U1334A-1H-CC and 320-U1334B-1H-CC, which contain a middle Miocene diatom assemblage consisting of Cavitatus jouseanus, Rossiella paleacea, Thalassiosira yabei, C. coscinodiscus, and Denticulopsis simonsenii. Several of these species are suggestive of placement in the lower portion of the C. coscinodiscus Zone. Note that reworking of older specimens, such as Rocella vigilans, is recognized in this sample. No zonal assignment is possible for Samples 320U1334A-2H-CC through 8H-CC.

The interval from Samples 320-U1334A-9H-2, 110$111 \mathrm{~cm}$, through $10 \mathrm{H}-4,110-111 \mathrm{~cm}$, is assigned to the $R$. fennerae Zone based on the occurrence of Bogorovia veniamini and Craspedodiscus barronii without Rocella gelida or $R$. vigilans. Also characteristic of this interval are C. jouseanus, Azpeitia oligocenica, R. paleacea, and Cestodiscus pulchellus.

The interval from Samples 320-U1334A-10H-CC through $13 \mathrm{H}-2,115-116 \mathrm{~cm}$, is assigned to the $R$. gelida Zone based on the occurrence of $R$. gelida and C. baronii in this interval. This zonal assignment is supported by the occurrence of Rocella schraderi in Sample 320-U1334A-12H-2, 115-116 cm.

Diatoms are rare and typically have poor preservation in the interval from Samples 320-U1334A-13H-CC through $16 \mathrm{H}-2,110-111 \mathrm{~cm}$. The zonal assignment for this interval is tentative. Rozellea vigilans occurs in most samples examined in this interval. The occurrence of B. veniamini in Section 320-U1334A$15 \mathrm{H}-2$ and Sample 320-U1334A-15H-4, 110-111 cm, suggests placement of these samples in the $B$. veniamini Zone. Such a zonal placement is supported by the occurrence of Cestodiscus kugleri in Sample 320U1334A-14H-2, 110-111 cm.

The interval from Samples 320-U1334A-16H-4, 110$111 \mathrm{~cm}$, through $20 \mathrm{H}-2,115-116 \mathrm{~cm}$, is assigned to the $R$. vigilans Zone based on the occurrence of $R$. vigilans without $B$. veniamini. The occurrence of Kozloviella minor in Sample 320-U1334A-17H-2, 110$111 \mathrm{~cm}$, suggests placement of this sample in Subzone $\mathrm{C}$ of the $R$. vigilans Zone. The occurrence of Rossiella symmetrica in Sample 320-U1334A-17H-4, $110-111 \mathrm{~cm}$, suggests placement of this sample in Subzone B of the R. vigilans Zone. Samples examined immediately below this interval (Samples 320U1334A-20H-4, 115-116 cm, through 22H-CC) contain rare diatoms or poor preservation and are not zoned.

Section 320-U1334A-23X-2 is assigned to the Cestodiscus trochus Zone based on the occurrence of $C$. trochus without $R$. vigilans or $C$. excavatus. The interval from Samples 320-U1334A-23X-4, 90-91 cm, through $26 \mathrm{X}-4,111-112 \mathrm{~cm}$, is assigned to the C. excavatus Zone based on the occurrence of $C$. excavatus. Samples examined in Cores 320-U1334A-27X and below are unzoned because of the paucity of diatoms and/or the state of diatom preservation. One sample of note in this interval is Sample 320-U1334A-29X-1, 129-130 cm, which contains common diatom fragments including Hemiaulus.

\section{Planktonic foraminifers}

Core catchers were sampled from all three holes at Site U1334, and additional samples were taken in Hole U1334A (two per core) to develop a high-resolution biostratigraphy. Preservation and abundance is variable in the middle Miocene but improves downcore with good preservation recorded in the early Miocene and for much of the Oligocene. As found at previous Sites U1331-U1333, both preservation and abundance decreases across the Eocene/Oligocene boundary. Planktonic foraminifer biostratigraphy at this site indicates a middle Eocene through middle Miocene from Zone E13 or higher to Zone M9b/N12, which agrees well with calcareous nannofossil and 
radiolarian zonal determinations (Fig. F13). Depth positions and age estimates of biostratigraphic marker events identified are shown in Table T8. Taxon abundance and planktonic foraminifer preservation are shown in Table T9.

The topmost planktonic foraminifer zone recognized is Zone M9b/N12 in the middle Miocene defined by the base of Globorotalia (Fohsella) fohsi robusta in Sample 320-U1334A-2H-CC (18.11 m CSF). This sample is well preserved and contains a diverse fauna including Globorotalia (Fohsella) fohsi lobata, Sphaeroidinellopsis disjuncta, Dentoglobigerina altispira, and Paragloborotalia mayeri. Zones M5-M9a/N8-N12 are undifferentiated between Samples 320-U1334A-2HCC and 4H-2, 38-40 cm (29.08 m CSF). Praeorbulina sicana was identified in Sample 320-U1334A-4H-2, $38-40 \mathrm{~cm}$, but the base of Zone M5 was undefined because underlying Samples 320-U1334A-4H-CC, $320-\mathrm{U} 1334 \mathrm{~B}-4 \mathrm{H}-\mathrm{CC}$, and $320-\mathrm{U} 1334 \mathrm{C}-4 \mathrm{H}-\mathrm{CC}$ are barren or contain only very rare planktonic foraminifers. Zones M2-M4 were determined between the last occurrences of P. kugleri and P. pseudokugleri and the barren interval above which Zone M5 is identified. $P$. sicana was not found, indicating sediments younger than Zone M5. The absence of Globigerinatella insueta prevented further subdivision of Zones M2-M3, and Zones M3 and M4 were not differentiated because the last occurrence of Catapsydrax dissimilis was not reliable. The overlapping ranges of Globoquadrina dehiscens, P. kugleri, and P. pseudokugleri defines Zone M1b between Samples 320-U1334A-5H6 , 39-41 cm (44.59 $\mathrm{m} \mathrm{CSF})$, and 8H-CC $(75.06 \mathrm{~m}$ CSF). Zone M1a occurs between the base of G. dehiscens in Sample 320-U1334A-8H-CC (75.06 m CSF) and the base of $P$. kugleri in Sample 320-U1334A$10 \mathrm{H}-2,38-40 \mathrm{~cm}$ (86.08 m CSF).

The Oligocene/Miocene boundary is constrained at Site U1334 between Samples 320-U1334A-10H-2, $38-40 \mathrm{~cm}$ (86.08 $\mathrm{m} \mathrm{CSF})$, and $10 \mathrm{H}-5,38-40 \mathrm{~cm}$ (90.58 m CSF), by the base of P. kugleri, which is present throughout its stratigraphic range in low abundance. Zone $\mathrm{O} 6$ is determined between the base of $P$. kugleri and the top of Paragloborotalia opima. The top and base of $P$. opima between Samples 320-U1334A$17 \mathrm{X}-2,10-12 \mathrm{~cm}$ (152.58 $\mathrm{m} \mathrm{CSF})$, and $22 \mathrm{X}-4,38-$ $40 \mathrm{~cm}$ (203.80 m CSF), respectively, indicates Zones O2-O5. The lowest occurrence or base of Globigerina angulisuturalis falls within the range of $P$. opima in Sample 320-U1334A-19X-2, 38-40 cm (172.18 m CSF), and enables the distinction of Zones $\mathrm{O} 4$ and O5. The paucity of Chiloguembelina cubensis prevents Zones $\mathrm{O} 4$ and $\mathrm{O} 5$ from being differentiated. The top of Turborotalia ampliapertura is defined in both Holes U1334B and U1334C between Samples 320-U1334B22H-CC and 23X-CC and Samples 320-U1334C-22H-
CC and 23X-CC, respectively (Table T8). At Site U1334A, T. ampliapertura occurs sporadically and the datum is found at a lower stratigraphic level. It is not possible to divide planktonic foraminifer Zones $\mathrm{O} 1$ and $\mathrm{O} 2$ because of the absence of Pseudohastigerina naguewichensis from the assemblage.

As noted at previous sites, definition of the Eocene/ Oligocene boundary is hindered by the absence of Hantkenina, which may at least in part be attributed to enhanced dissolution during this time interval and, thus, reduced foraminifer abundances and preservation but also related to the paleoecological preferences of the late Eocene hantkeninids (Coxall et al., 2003). In the absence of Hantkenina sp., the Eocene/Oligocene boundary is approximated at Site U1334 using the first occurrence of Globoquadrina venezuelana in Sample 320-U1334C-25X-CC (233.32 $\mathrm{m} \mathrm{CSF}$ ) and the first consistent presence of Catapsydrax unicavus in Sample 320-U1334C-26X-CC (240.51 m CSF). This approximation agrees well with the placement of the Eocene/Oligocene boundary in Tanzania (Wade and Pearson, 2008) and the radiolarian and nannofossil biostratigraphy.

Middle-late Eocene sediments contain a moderately preserved assemblage indicative of Zones E13-E16. The assemblage is dominated by small parasubbotinids, paragloborotaliids, and subbotinids. Taxa identified include Dentoglobigerina tripartita, Paragloborotalia griffinoides, Parasubbotina griffinae, Paragloborotalia nana, Subbotina angiporoides, Subbotina eocaena, Turborotalia increbescens, and Turborotalia pomeroli. The lack of Globigerinatheka, Acarinina, and Morozovelloides prevents differentiation of individual zones within the middle-late Eocene. The presence of Subbotina linaperta in Sample 320-U1334A-30X-6, $48-50 \mathrm{~cm}$ (280.08 m CSF), indicates a basement age older than $37.7 \mathrm{Ma}$ (Berggren et al., 1995). This is consistent with the age of basement estimated using calcareous nannofossils between 37.1 and 38.0 Ma.

\section{Benthic foraminifers}

Benthic foraminifers were examined semiquantitatively from the three holes of Site U1334. Benthic foraminifers are almost continuously present in samples from Site U1334. The distribution of benthic foraminifers at this site is shown in Table T10.

The uppermost sample in Hole U1334A (Sample 320U1331A-1H-CC; $8.22 \mathrm{~m} \mathrm{CSF)} \mathrm{contains} \mathrm{only} \mathrm{rare} \mathrm{ben-}$ thic foraminifers and preservation varies from poor to moderate. In Samples 320-U1334A-2H-CC and 3H-CC (18.14 and $27.68 \mathrm{~m}$ CSF, respectively), Oridorsalis umbonatus, Nuttallides umbonifer, Cibicidoides mundulus, and Globocassidulina subglobosa are common and Pullenia bulloides, Spheroidina bulloides, Melonis pomplioides, and Melonis barleeanum are 
subordinate. A similar fauna is found in Samples 320-U1334B-1H-CC through 3H-CC (13.71-32.65 m CSF) and 320-U1334C-1H-CC through 3H-CC (9.84$28.10 \mathrm{~m} \mathrm{CSF}$ ). Middle Miocene taxa identified here indicate lower bathyal and abyssal paleodepths (van Morkhoven et al., 1986).

In Samples 320-U1334A-4H-CC through 25X-CC (37.21-233.98 m CSF), O. umbonatus, N. umbonifer, C. mundulus, G. subglobosa, and Gyroidinoides spp. are common and P. bulloides, Astrononion echolsi, and Cibicidoides grimsdalei are subordinate. Samples 320U1334A-4H-CC and 9H-CC (37.21 and $84.77 \mathrm{~m} \mathrm{CSF}$, respectively) contain rare benthic foraminifers, but agglutinated forms are common. Preservation of foraminifer tests is good to moderate, except in Samples 320-U1334A-4H-CC and 9H-CC. Similar benthic foraminifer taxa are also recognized in Holes U1334B (Samples 320-U1334B-4H-CC through 26X-CC; 41.95-247.89 m CSF) and U1334C (Samples 320U1334C-4H-CC through 26X-CC; 38.30-240.73 m CSF). There is no marked difference in faunal composition or preservation of benthic foraminifers between the green-colored sediments (e.g., Samples U1334A$16 \mathrm{H}-\mathrm{CC}$ through 20H-CC) and other white-colored sediments in the Oligocene. Faunal compositions recorded here indicate lower bathyal and abyssal paleodepths during the Oligocene and the early Miocene, similar to those of Sites U1332 and U1333 and previous studies in the eastern equatorial Pacific (ODP Site 573, Thomas, 1985; ODP Sites 1218 and 1219, Takata and Nomura, 2005). N. umbonifer and C. mundulus occur in high abundances in the Oligocene of Site U1334, but they show a more sporadic stratigraphic distribution than at Sites U1332 and U1333 (Fig. F15). Other minor species-C. grimsdalei, P. bulloides, S. bulloides, A. echolsi, and Gyroidinoides spp.--have more variable abundances than observed at Sites U1332 and U1333. These subtle differences in Oligocene benthic foraminifer fauna may arise from variations in water mass properties with depth. For example, the discontinuous abundance of N. umbonifer, a species tolerant to carbonate undersaturation and/or low food supply (e.g., Mackensen et al., 1990; Schmiedl et al., 1997), at Site U1334 in the Oligocene could be interpreted as a reduced influence of Southern Component Water and/or carbonate undersaturation of deep water compared to other sites.

Benthic foraminifers are present in Samples 320U1334A-26X-CC through 31X-CC (243.39-283.92 m CSF), including common O. umbonatus, Nuttallides truempyi, C. grimsdalei, and G. subglobosa. Similar occurrences are also recognized in Samples 320U1334B-27X-CC through 29X-CC (257.73-276.92 m CSF) and 320-U1334C-27X-CC through 30X-CC (248.17-277.95 m CSF). In addition, various taxa, such as Abyssamina quadrata, Abyssamina poagi, Alabamina dissonata, Anomalinoides sp. A, and Gyroidinoides spp., are subordinate in Sample 320-U1334C-30XCC. Preservation of these calcareous foraminifers is generally poor. These faunal assemblages suggest lower bathyal to abyssal paleodepths in the middle to late Eocene. Faunal associations of these calcareous taxa in the middle to late Eocene are basically similar to those of Sites U1331-U1333 and previous preliminary studies in the eastern equatorial Pacific (Site 1218, Wilson, Lyle, and Firth, 2006).

\section{Paleomagnetism}

We studied the paleomagnetism of sediments from Site U1334 with a primary focus on determining a preliminary magnetostratigraphy, which can be used to assist in dating the stratigraphic section. To accomplish this, we measured the natural remanent magnetization (NRM) of archive-half sections from 66 APC cores recovered from Holes U1334A-U1334C. Measurements were made along each section at $5 \mathrm{~cm}$ intervals before and after alternating-field (AF) demagnetization of $20 \mathrm{mT}$. When time permitted, some sections were measured at 1 or $2.5 \mathrm{~cm}$ intervals. We found the higher resolution data to be more useful than measuring the 5,10 , or $15 \mathrm{mT}$ demagnetization steps as had been done at the previous sites. We also did not measure archive-half sections of any $\mathrm{XCB}$ cores at this site because the shallow paleomagnetic inclination of the sediments along with the relative azimuthal rotation that occurs between adjacent pieces of XCB core (referred to as "drilling biscuits") results in neither useful intensity nor direction data.

We processed the paleomagnetic data by removing measurements made within $5 \mathrm{~cm}$ of section ends and data from disturbed intervals (Table T11). Cleaned data are presented in Tables T12, T13, T14, T15, T16, and T17 and Figures F16, F17, and F18.

Azimuthal core orientation was determined solely by correlating distinct reversal patterns as recorded by paleomagnetic declinations in each hole with the geomagnetic polarity timescale (GPTS) (See "Paleomagnetism" in the "Methods" chapter and "Paleomagnetism" in the "Site U1331" chapter). This process is aided by rather detailed age constraints, which significantly limit the range of possible correlations with the GPTS (see "Biostratigraphy"). Once we had confidently identified a unique, unambiguous reversal pattern, the mean paleomagnetic directions for each core were calculated using Fisher statistics (Table T18). Subsequently, data were reoriented so that normal and reversed polarity magnetozones had declinations of $\sim 0^{\circ}$ and $\sim 180^{\circ}$, respectively (see 
"Paleomagnetism" in the "Site U1331" chapter). Reoriented declinations are provided for Holes U1334A-U1334C in Tables T13, T15, and T17, respectively, for data collected after AF demagnetization at $20 \mathrm{mT}$.

We measured magnetic properties of 188 discrete paleomagnetic samples, with one sample collected from nearly every section in Hole U1334A. Of these, 87 samples were subjected to progressive AF demagnetization up to $60 \mathrm{mT}$. Remanence measurements and characteristic remanent magnetization (ChRM) directions computed using principal component analysis (PCA) are given in Tables T19 and T20, respectively. Magnetic susceptibilities and masses, along with volumes estimated using MAD data (see "Physical properties"), are given in Table T21. This table also includes magnetic susceptibilities from whole-core data for the intervals corresponding to where the discrete samples were taken, which is useful for checking the scale factor, $0.68 \times 10^{-5}$ (see "Paleomagnetism" in the "Methods" chapter), for converting the whole-core raw susceptibility meter measurements into true volume-normalized susceptibility values.

\section{Results}

Downhole variations in paleomagnetic data from split-core and discrete samples and susceptibility data from whole-core and discrete samples are shown in Figures F16, F17, and F18. The most prominent features of the records are

1. The clear $180^{\circ}$ alternations in declination for the upper $140-150 \mathrm{~m}$ CSF of the section, reflecting the magnetic polarity zones (magnetozones);

2. The remanent magnetic intensity and magnetic susceptibility low that occurs between 135 and $210 \mathrm{~m}$ CSF, referred to as the magnetic-low zone; and

3. The general degradation of the paleomagnetic direction within the magnetic-low zone with further degradation at the depth where coring switched from using nonmagnetic to steel core barrels (compare the results above and below the dashed line in Figs. F16, F17, and F18).

The magnetic-low zone can be attributed to reduction diagenesis, whereby oxygen from fine-grained iron oxides (titanomagnetite and magnetite) is used by bacteria to break down organic matter. This mobilizes iron and converts some of the iron oxides into various iron sulfides, most of which have very low magnetic susceptibilities and retain little or no remanent magnetization.

Unlike Sites U1331 and U1332, where the drilling overprint was present regardless of which type of core barrel was used, the drilling overprint was generally weak for Site U1334 cores when nonmagnetic core barrels were used (Cores 320-U1334A-1H through $16 \mathrm{H}, 320-\mathrm{U} 1334 \mathrm{~B}-1 \mathrm{H}$ through $15 \mathrm{H}$, and $320-\mathrm{U} 1334 \mathrm{C}-1 \mathrm{H}$ through $15 \mathrm{H}$ ). In contrast, those cores collected with steel core barrels are highly overprinted, similar to what was observed at Site U1333 (Fig. F19). At Site U1334, the overprint appears more severe than at any of the other sites, which might be related to mineralogy (replacement of the primary iron oxides with iron sulfides). Whatever the cause, even demagnetization at $20 \mathrm{mT}$ fails to remove the overprint fully. As a result, paleomagnetic declination data have notably higher variability, which makes polarity determination much more difficult in the intervals collected with steel core barrels.

Discrete sample demagnetization data from cores collected above $\sim 130 \mathrm{~m}$ CSF (those collected with nonmagnetic core barrels and that are above the magnetic-low zone) indicate that the ChRM of the sediments can be resolved by AF demagnetization above $10 \mathrm{mT}$ (Fig. F20). We interpret this ChRM to be the primary depositional remanent magnetization. Unlike most of the samples from Sites U1331U1333, most Site U1334 samples have more poorly resolved ChRM directions (more scattered directions along a linear demagnetization path in the orthogonal demagnetization plot). We attribute this mainly to the weaker magnetization of Site U1334 sediments. For example, within the magnetic-low zone, magnetizations are very close to the noise level of the magnetometer. Even more strongly magnetized intervals are only about an order of magnitude above the noise level. Generally, those samples that are sufficiently strongly magnetized yield linear demagnetization paths that decay toward but do not terminate at the origin of the orthogonal demagnetization diagrams (Fig. F20). This offset from the origin most likely reflects measurement artifacts (a small anhysteretic magnetization imparted to samples as they are demagnetized). Even with this artifact, ChRM directions for the more strongly magnetized samples are well constrained. These ChRMs, estimated from the linear demagnetization paths using PCA, agree well with those of coeval intervals of the archive-half measurements (Fig. F16), indicating that magnetic directions from the split cores after $20 \mathrm{mT}$ demagnetization step provide a reliable indicator of the ChRM of the sediments.

\section{Magnetostratigraphy}

Cleaned paleomagnetic data provide a series of distinct $\sim 180^{\circ}$ alternations in declination and subtle changes in inclination, which, when combined with biostratigraphic age constraints, allow a continuous 
magnetostratigraphy to be constructed that correlates well with the GPTS. The magnetostratigraphic record extends from the top of Chron C1n (0 Ma) at the mudline of Hole U1334A ( $0 \mathrm{~m} \mathrm{CSF}$ ) to the top of Chron C11r (29.957 Ma) at $195.06 \mathrm{~m}$ CSF in Hole U1334C (Figs. F19, F21, F22; Table T22). The interpretation is complicated in only two intervals. The first complication occurs for the thin Pliocene and Pleistocene section, which was cored only once (in the upper $5 \mathrm{~m} \mathrm{CSF}$ of Hole U1334A) (Fig. F21A). Either coring deformation or hiatuses make it difficult to connect what appear to be Chrons C1n through $\mathrm{C} 2 \mathrm{n}$ in the upper $2 \mathrm{~m}$ of Core $320-\mathrm{U} 1334 \mathrm{~A}-1 \mathrm{H}$ to a clear continuous sequence of magnetozones that correlate well from the base of Chron C3r at 5.3 and $1.8 \mathrm{~m}$ CSF in Holes U1334A and U1334C, respectively, to the top of Chron C9n (26.508 Ma) at 139.5, 136.2, and $131.9 \mathrm{~m}$ CSF in Holes U1334A-U1334C, respectively. Below this, correlation of the magnetozones to Chrons $\mathrm{C} 9 \mathrm{r}-\mathrm{C} 12 \mathrm{n}$ is more speculative as a result of the more variable declinations in the magnetic-low zone and the larger drilling overprint, as discussed above. We consider it too speculative to correlate the highly variable declinations from Cores 320-U1334A-22H, 320-U1334B-22H, or 320U1334C-22H with the GPTS. Below these cores, only $\mathrm{XCB}$ cores were collected, from which polarity determination is improbable.

Some highlights of the magnetostratigraphy at Site U1334 include resolving a clear sequence of magnetozones corresponding to Chrons C3r-C9n, which yield a total of 250 dated reversals from the three holes and provide detailed chronostratigraphic and sedimentation rate constraints (see "Stratigraphic correlation and composite section"), the identification of a previously observed cryptochron (C5Dr- $1 \mathrm{n})$ in all three holes, and the identification of eight possible excursions, seven of which are recorded in at least two of the holes (Table T22; Figs. F19, F21, F22).

\section{Geochemistry}

\section{Sediment gases sampling and analysis}

Headspace gas samples were taken at a frequency of one sample per core in Hole U1334A as part of the routine environmental protection and safety monitoring program. All headspace sample analyses resulted in nondetectable levels of methane $\left(\mathrm{C}_{1} ;<1 \mathrm{ppmv}\right)$, with no higher hydrocarbons, consistent with the low organic carbon content of these sediments.

\section{Interstitial water sampling and chemistry}

Thirty-four interstitial water samples were collected using the whole-round squeezing approach (Table
T23; Fig. F23). In addition, 61 samples were taken using Rhizon samplers from Sections 320-U1334B$13 \mathrm{H}-5$ and $13 \mathrm{H}-6$ and $320-\mathrm{U} 1334 \mathrm{C}-13 \mathrm{H}-5$ through 23X-3 with a sampling frequency of one sample per section, resulting in a stratigraphic resolution of $\sim 1.5 \mathrm{~m}$ (Table T24; Fig. F24). This depth interval was selected for Rhizon sampling to study the profiles of dissolved $\mathrm{Mn}$ and Fe of the interstitial water geochemistry revealed by the whole-round samples (Fig. F23) in more detail. Chemical constituents were determined according to the procedures outlined in "Geochemistry" in the "Methods" chapter. In this section, we first describe the overall site geochemistry based on the whole-round samples and then present a more detailed comparison of elements analyzed by squeezed and Rhizon samples in the depth interval of their overlap.

Chlorinity shows relatively little variability with depth, with values ranging mainly from 553 to 566 mM (Fig. F23; Table T23). However, chlorinity values reveal a distinct increase from 553 to $565 \mathrm{mM}$ in the uppermost $30 \mathrm{~m} \mathrm{CSF}$, potentially reflecting the change from the more saline ocean at the Last Glacial Maximum to the present (Adkins and Schrag, 2003). Alkalinity shows little variability with values ranging from 2.7 to $4.0 \mathrm{mM}$. Sulfate concentrations vary between 24 and $29 \mathrm{mM}$, with decreasing values in the upper $60 \mathrm{~m} \mathrm{CSF}$ and higher values below $250 \mathrm{~m}$ CSF. Dissolved phosphate concentrations are $\sim 2 \mu \mathrm{M}$ in the shallowest sample, decreasing to $\sim 0.5 \mu \mathrm{M}$ in the uppermost $\sim 15 \mathrm{~m}$ CSF. Dissolved manganese peaks with concentrations of up to $6 \mu \mathrm{M}$ between $\sim 50$ and $150 \mathrm{~m} \mathrm{CSF}$, with peak manganese values (at $\sim 110 \mathrm{~m} \mathrm{CSF}$ ) shallower than the peak dissolved iron value of $6 \mu \mathrm{M}$ between 150 and $180 \mathrm{~m}$ CSF. Because of the relatively high sulfate concentrations, dissolved Ba concentrations are low and relatively homogeneous, with values between 0.8 and $1.5 \mu \mathrm{M}$. Concentrations of dissolved silicate increase with depth from $\sim 400$ to $\sim 850 \mu \mathrm{M}$.

Calcium and magnesium concentrations are relatively uniform, with values ranging from 10.2 to 11.5 and from 50 to $53 \mathrm{mM}$, respectively (Fig. F23).

Lithium concentrations decrease from $\sim 26 \mu \mathrm{M}$ at the surface to $15 \mu \mathrm{M}$ at $\sim 100 \mathrm{~m} \mathrm{CSF}$, with the strongest decrease apparent between 10 and $20 \mathrm{~m}$ CSF. Lithium strongly increases below $220 \mathrm{~m}$ CSF toward basement. Strontium concentrations range between 78 and $107 \mu \mathrm{M}$. Values show an increase from the top toward $110 \mathrm{~m} \mathrm{CSF}$, followed by a decrease toward basement. Boron concentrations range between 400 and $500 \mu \mathrm{M}$, showing a relatively constant decrease from top to basement.

Interstitial water samples derived from Rhizon and whole-round squeezing show good agreement for 
some elements (Fig. F25). Because these two data sets were collected in different holes, data are plotted in CCSF-A depths to facilitate comparison. In the depth range of overlap, the more frequently sampled Rhizon profiles and the squeezed profiles give comparable absolute values and profile shapes for some elements (Fig. F25), especially when considering the analytical reproducibility of shipboard techniques (see the "Methods" chapter). This includes elements with relatively constant depth profiles (e.g., sulfate and silicate) and those with relatively large concentration changes (e.g., manganese).

The deepest three Rhizon samples were taken in the first three sections of the first core at this hole to be cored with the XCB. The more fragmented nature of the recovered sediments led to Rhizon samples that very rapidly filled with water and to results that appear more contaminated with seawater drilling fluid. Rhizon profiles are noisier, partially because of the greater depth resolution of sampling and the limits of analytical reproducibility. However, some of this variability appears related to actual sampling variability between Rhizons in a single depth profile and between holes regardless of sampling technique. For example, one Rhizon sample shows clear signs of drill fluid contamination as excursions toward seawater values are observed for several elements (alkalinity, silicate, lithium, and strontium in Sample 320-U1334C-15H-1, 75 cm; 161.98 m CCSF-A) (Fig. F25), but this sample was taken in an area of clear drilling disturbance.

We were particularly interested in the iron and manganese profiles, indicative of suboxic oxidation of organic carbon by manganese oxide and iron oxide reduction. The depth zone with high dissolved iron concentrations corresponds to the depth zone of low magnetic susceptibility (Fig. F25) and the tail of the dissolved manganese peak (Figs. F23, F25). We reran the squeezed samples with the Rhizon samples for dissolved manganese and iron, finding generally excellent analytical reproducibility on the replicate runs. The Rhizon and squeezed profiles agree well for dissolved manganese, with some occasional excursions in the Rhizon samples to higher manganese concentrations. The iron profiles also generally agree well. The exceptions are two substantially higher iron values in the squeezed samples in the 160$180 \mathrm{~m}$ CCSF-A range, the depth interval of the color change from yellowish gray to greenish gray. This may represent true interhole variability or a sampling artifact.

\section{Bulk sediment geochemistry: major and minor elements}

At Site U1334, bulk sediment samples for minor and major element analyses were distributed over the core depth to characterize the major lithologic units (0-280 m CSF; Hole U1334A). We analyzed concentrations of silicon, aluminum, iron, manganese, magnesium, calcium, sodium, potassium, titanium, phosphorus, barium, copper, chromium, scandium, strontium, vanadium, yttrium, and zirconium in the sediments by inductively coupled plasma-atomic emission spectroscopy (ICP-AES) (Table T25).

$\mathrm{SiO}_{2}$ ranges between 7 and $54 \mathrm{wt} \%$, with values decreasing from $50 \mathrm{wt} \%$ at the surface to values $<10 \mathrm{wt} \%$ between 50 and $220 \mathrm{~m}$ CSF. Below $220 \mathrm{~m}$ $\mathrm{CSF}, \mathrm{SiO}_{2}$ concentrations vary between 7 and $54 \mathrm{wt} \%$, with concentrations below $10 \mathrm{wt} \%$ near the basement. Concentrations of $\mathrm{Al}_{2} \mathrm{O}_{3}$ range from 0.2 to $12 \mathrm{wt} \%$, with values decreasing in the upper $50 \mathrm{~m}$ CSF from 12 to $<1 \mathrm{wt} \%$. Between 50 and $250 \mathrm{~m} \mathrm{CSF}$, $\mathrm{Al}_{2} \mathrm{O}_{3}$ concentrations are mainly below $1 \mathrm{wt} \%$. Around 250-260 m CSF, $\mathrm{Al}_{2} \mathrm{O}_{3}$ concentrations slightly increase to $2 \mathrm{wt} \%$. A distribution with depth similar to that of $\mathrm{Al}$ is shown by $\mathrm{TiO}_{2}(0.006-$ $0.6 \mathrm{wt} \%), \mathrm{K}_{2} \mathrm{O}(0.1-2.2 \mathrm{wt} \%), \mathrm{Zr}(18-240 \mathrm{ppm})$, and Sc (0.5-40 ppm).

Concentrations of $\mathrm{Fe}_{2} \mathrm{O}_{3}$ vary between 0.5 and $10 \mathrm{wt} \%$, following the general pattern of $\mathrm{SiO}_{2}$. Similar trends are also shown by $\mathrm{MnO}(0.07$ to $>0.2 \mathrm{wt} \%)$, $\mathrm{MgO}$ (0.4-4 wt $\%)$, copper (45 to $>140 \mathrm{ppm})$, and vanadium (up to $115 \mathrm{ppm}$ ). The peak concentrations of $\mathrm{Mn}$ and $\mathrm{Cu}$ could not be quantified because they exceeded the calibrated range (Table T24).

Calcium $(\mathrm{CaO})$ ranges from 1 to $42 \mathrm{wt} \%$, with high values corresponding to minima in $\mathrm{SiO}_{2}$ and $\mathrm{Al}_{2} \mathrm{O}_{3}$. Strontium concentrations range from 345 to $>700 \mathrm{ppm}$, showing a similar pattern to $\mathrm{CaO}$. Barium and $\mathrm{P}_{2} \mathrm{O}_{5}$ values range from below detection limit to $>566 \mathrm{ppm}$ and $1 \mathrm{wt} \%$, respectively, showing minima at high $\mathrm{CaO}$ concentrations.

\section{Bulk sediment geochemistry: sedimentary inorganic and organic carbon}

$\mathrm{CaCO}_{3}$, inorganic carbon (IC), and total carbon (TC) concentrations were determined on sediment samples from Hole U1334A (Table T26; Fig. F6). $\mathrm{CaCO}_{3}$ concentrations ranged between $<1$ and $95 \mathrm{wt} \%$. In the uppermost $\sim 16 \mathrm{~m} \mathrm{CSF}, \mathrm{CaCO}_{3}$ concentrations are very low $(<1 \mathrm{wt} \%)$ and then, from 16 to $46 \mathrm{~m} \mathrm{CSF}$, vary greatly between $<1$ and $74 \mathrm{wt} \%$. Carbonate concentrations are consistently high (74-95 wt\%), from 46 to $247 \mathrm{~m} \mathrm{CSF}$, with a few relatively low concentrations at 57.9, 87.9, 103, and $116.9 \mathrm{~m}$ CSF. From 247 to $260 \mathrm{~m} \mathrm{CSF}, \mathrm{CaCO}_{3}$ concentrations are low $(<1-$ $56 \mathrm{wt} \%$ ). Below $260 \mathrm{~m} \mathrm{CSF}, \mathrm{CaCO}_{3}$ concentrations are variable, ranging between 37 and $86 \mathrm{wt} \%$. Variations in $\mathrm{CaCO}_{3}$ concentrations correspond to lithostratigraphic changes (see "Lithostratigraphy"). 
Total organic carbon (TOC) concentrations were determined by acidification (see "Geochemistry" in the "Methods" chapter) (Table T26; Fig. F6) and are very low throughout the sediment column, with a range from below the detection limit to $0.15 \mathrm{wt} \%$ (Fig. F24).

\section{Physical properties}

Physical properties at Site U1334 were measured on whole cores, split cores, and discrete samples. WRMSL (GRA bulk density, magnetic susceptibility, and $P$-wave velocity), thermal conductivity, and NGR measurements comprised the whole-core measurements. Compressional wave velocity measurements on split cores and MAD analyses on discrete core samples were made at a frequency of one per undisturbed section in Cores 320-U1334A-1H through $31 \mathrm{X}$ (Table T27). Compressional wave velocities were measured toward the bottom of sections. MAD analyses were located $10 \mathrm{~cm}$ downsection from carbonate analyses (see "Geochemistry"). Lastly, the Section Half Multisensor Logger (SHMSL) was used to measure spectral reflectance on archivehalf sections.

\section{Density and porosity}

Two methods were used to evaluate wet bulk density at Site U1334. GRA provided an estimate from whole cores (Fig. F26). MAD samples gave a second, independent measure of wet bulk density, along with providing dry bulk density, grain density, water content, and porosity from discrete samples (Table T28). MAD and GRA bulk density measurements display the same trends and are also similar in absolute values through the entire section (Fig. F27B). Crossplots of wet and dry bulk density versus interpolated GRA density (Fig. F28) show good correlation between MAD and GRA data.

Generally, wet bulk density corresponds with changes in lithology. Bulk density is very uniform for the first $15 \mathrm{~m}$ within Unit I, corresponding to a clay-rich interval at the top of the section (see "Lithostratigraphy"). An increase toward higher and less uniform bulk density values occurs in the lower part of Unit I. In Unit II, bulk density increases to values of $\sim 1.6 \mathrm{~g} / \mathrm{cm}^{3}$, reflecting the major lithology of this lithostratigraphic unit, nannofossil ooze. In Hole U1334A, bulk density decreases from 1.7 to $1.5 \mathrm{~g} / \mathrm{cm}^{3}$ at $205 \mathrm{~m} \mathrm{CSF}$. A similar decrease occurs at $210 \mathrm{~m} \mathrm{CSF}$ in Hole U1334B. A very slight trend toward higher bulk density begins at the ooze-chalk transition between Unit II and Subunit IIIa. Subunit IIIb is marked by a prominent decrease in bulk density.
Within Subunit IIIb, bulk density begins to increase toward the base of the section.

Variation in grain density in Hole U1334A generally matches changes in lithology (Fig. F27C). Grain density is highly variable with values between 2.1 and $2.9 \mathrm{~g} / \mathrm{cm}^{3}$ in Unit I and the top of Unit II. Within Unit II, below $90 \mathrm{~m} \mathrm{CSF}$, grain densities are more uniform $\left(2.7 \mathrm{~g} / \mathrm{cm}^{3}\right)$, reflecting the character of the major lithology, nannofossil ooze. Grain density is slightly less uniform in Subunits IIIa and IIIb, with lower values $\left(2.2 \mathrm{~g} / \mathrm{cm}^{3}\right)$.

Porosity averages $85 \%$ in the top of Unit I and decreases to $75 \%$ in the lower section of Unit I (Fig. F27). Porosity becomes uniform in the upper $80 \mathrm{~m}$ of Unit II, with values of $\sim 65 \%$ to $75 \%$. Below $130 \mathrm{~m}$ CSF, porosity becomes more uniform and shows a slight downhole decrease to between $60 \%$ and $70 \%$. Porosity increases slightly in Subunit IIIa and shows little change in Subunit IIIb.

\section{Magnetic susceptibility}

Whole-core magnetic susceptibility measurements correlate well with major differences in lithology and changes in bulk physical properties (Fig. F26). Magnetic susceptibility values are high and variable $\left(10 \times 10^{-5}\right.$ to $\left.40 \times 10^{-5} \mathrm{SI}\right)$ in Unit I. A sharp drop in magnetic susceptibility occurs at the top of Unit II, owing to decreased concentration of ferromagnetic minerals in the nannofossil ooze-dominated lithology. The low values of this lithologic unit $\left(\sim 5 \times 10^{-5}\right.$ to $\left.10 \times 10^{-5} \mathrm{SI}\right)$ are punctuated in several places with small jumps in magnetic susceptibility to values as high as $30 \times 10^{-5} \mathrm{SI}$ (e.g., $55 \mathrm{~m} \mathrm{CSF}$ ). These jumps can generally be correlated from hole to hole. At $140 \mathrm{~m}$ CSF the magnetic susceptibility signal is lost because of iron reduction in the sediments (see "Geochemistry"). The magnetic susceptibility signal returns at $205 \mathrm{~m}$ CSF in Hole U1334A and at $210 \mathrm{~m}$ CSF in Hole U1334B. Magnetic susceptibility values are $10 \times 10^{-5} \mathrm{SI}$ and relatively uniform for the remainder of Unit II and Subunit IIIa. A sharp increase in magnetic susceptibility occurs at the base of Subunit IIIb.

\section{Compressional wave velocity}

\section{Shipboard results}

Whole-core $P$-wave logger (PWL) and discrete velocity measurements made on split cores follow similar trends. The velocity record of Site U1334 is unremarkable in Units I and II, with very uniform velocity values of $1500 \mathrm{~m} / \mathrm{s}$ (Fig. F26). A small increase in velocity to $\sim 1540 \mathrm{~m} / \mathrm{s}$ occurs in the middle of Unit II at $\sim 150 \mathrm{~m} \mathrm{CSF}$; this may be linked to the color change toward green sediments observed here (See "Lithostratigraphy"). A key transition in velocity 
occurs at the ooze/chalk boundary between Unit II and Subunit IIIa. Below this lithologic unit boundary, velocity values increase steadily to $1600 \mathrm{~m} / \mathrm{s}$ at the base of the section. Discrete velocity measurements along the $x_{-}, y_{-}$, and $z$-axis are in excellent agreement with the PWL for most of the section (Fig. F29). However, below the sonic discontinuity at $150 \mathrm{~m}$ CSF, velocity measurements in the $y$-axis become higher by $\sim 50 \mathrm{~m} / \mathrm{s}$ compared to PWL velocity measurements. Measuring discrete velocity became impossible below the ooze-chalk transition between Unit II and Subunit IIIa; large cracks formed during insertion of the transducers because of poor cohesion of the radiolarian-dominated sediments. Discrete $x$-axis velocity measurements closely track the PWL measurements throughout the section.

\section{Postcruise correction}

During the analysis of Site U1334 cores, it was decided that the consistently high $x$-direction values are the result of using an incorrect liner thickness. Based on a limited number of liner thickness measurements, it was decided that the liner correction should use $3.2 \mathrm{~mm}$ for the liner thickness. However, during the analysis of Hole U1337A cores, it was determined that high $x$-direction velocities do not result from thicker than expected core liner but instead are the result of using an incorrect value for the system delay associated with the contact probe (see "Physical properties" in the "Site U1337" chapter). Critical parameters used in this correction are system delay $=19.811 \mu \mathrm{s}$, liner thickness $=2.7 \mathrm{~mm}$, and liner delay $=1.26 \mu \mathrm{s}$. During the analysis of Hole U1337A cores, it was also determined that consistently low PWL velocities required the addition of a constant value that would produce a reasonable velocity of water $(\sim 1495 \mathrm{~m} / \mathrm{s})$ for the quality assurance/ quality control (QA/QC) liner (see "Physical properties" in the "Site U1337" chapter). These corrections have not been applied to the velocity data presented in this chapter.

\section{Natural gamma radiation}

Natural gamma radiation was measured on all whole cores at Site U1334 (Fig. F26). The highest NGR values are present at the seafloor ( 15 cps). NGR values decrease to the base of Unit I. NGR is uniform throughout Unit II and Subunit IIIa. A slight increase by $\sim 3$ cps accompanies the lithologic boundary between Subunits IIIa and IIIb.

\section{Thermal conductivity}

Thermal conductivity was measured on the third section of each core from Hole U1334A (Table T29). Thermal conductivity shows a strong dependence on porosity and lithology downhole through the succession (Figs. F30, F31). Decreased conductivity occurs with increasing porosity as increased interstitial spacing attenuates the applied current from the probe. Thermal conductivity is $0.8 \mathrm{~W} /(\mathrm{m} \cdot \mathrm{K})$ in Unit I and increases to a maximum value of $1.2-1.3 \mathrm{~W} /(\mathrm{m} \cdot \mathrm{K})$ in Unit II. Values decrease to $0.9 \mathrm{~W} /(\mathrm{m} \cdot \mathrm{K})$ in Subunits IIIa and IIIb.

\section{Reflectance spectroscopy}

Spectral reflectance was measured on split archive section halves from all three holes using the SHMSL (Fig. F32). The parameters $L^{*}$ (black-white), $a^{*}$ (green-red), and $\mathrm{b}^{*}$ (blue-yellow) follow changes in lithology, with variations in $\mathrm{L}^{*}, \mathrm{a}^{*}$, and $\mathrm{b}^{*}$ correlating very well to carbonate content, density, and magnetic susceptibility measurements (Figs. F5, F32). L* has relatively low amplitude variations around 80 in the carbonate section of Unit II, whereas in more radiolarian-dominated intervals, $L^{*}$ has lower values, with higher amplitude variation, ranging from 25 to 75. Except for the light greenish gray interval discussed later, $a^{*}$ and $b^{*}$ generally show high values $(\sim 5$ and 13 , respectively) with high-amplitude and high-frequency variation in the more carbonate dominated Unit II. The light greenish gray carbonate interval, between 144 and $190 \mathrm{~m} \mathrm{CSF}$, is clearly seen in the $a^{*}$ data as values shift to around -3 ; negative $a^{*}$ values are indicative of green colors. The $b^{*}$ values decrease sharply to $\sim 4$ in this interval before rapidly increasing back to 13 at its base. $\mathrm{L}^{*}, \mathrm{a}^{*}$, and $\mathrm{b}^{*}$ values all decrease at the boundary between Subunits IIIa and IIIb, correlating with the sudden increase in radiolarian content, which subsequently decreases toward the bottom of Subunit IIIb (whereas luminance values increase). The limestone present in Unit IV is represented by high values of $\mathrm{L}^{*}, \mathrm{a}^{*}$, and $\mathrm{b}^{*}$ (around 60,6 , and 15 , respectively) corresponding to its extremely light, almost white color.

\section{Stratigraphic correlation and composite section}

STMSL data were collected at $5 \mathrm{~cm}$ intervals from Holes U1334B and U1334C and compared to the WRMSL data obtained at $2.5 \mathrm{~cm}$ resolution from Hole U1334A. In this way we monitored drilling in Holes U1334B and U1334C in real time to recover and construct a stratigraphically complete composite section. Several intervals between Holes U1334A and U1334B did not overlap sufficiently to cover gaps between cores. Thus, coring of Hole U1334C was designed to recover the missing intervals, as well as to provide additional material for high-resolution studies. The coring effort in Hole U1334C was successful 
at covering gaps between cores in Holes U1334A and U1334B to $222 \mathrm{~m}$ CCSF-A (Figs. F33, F34) and from 250 to 336 m CCSF-A, almost to the bottom of the section. Stratigraphic correlation between the three holes at Site U1334 was challenging in the light greenish gray interval (Cores 320-U1334A-15H through $22 \mathrm{H}, 320-\mathrm{U} 1334 \mathrm{~B}-14 \mathrm{H}$ through $22 \mathrm{H}$, and $320-\mathrm{U} 1334 \mathrm{C}-14 \mathrm{H}$ through $22 \mathrm{H}$ ), which is characterized by very low magnetic susceptibilities, and in the bottom $\sim 80 \mathrm{~m}$, where coring with the XCB compromised core quality. The correlation between the three holes for the chosen parameters was adequate to good and, in some depth intervals, excellent. The gaps between successive cores in any of the holes are on the order of 1 to $2 \mathrm{~m}$, with a maximum of $\sim 4 \mathrm{~m}$ between Cores $320-\mathrm{U} 1334 \mathrm{C}-3 \mathrm{H}$ and $4 \mathrm{H}$ and $\sim 14 \mathrm{~m}$ between Cores 320-U1334A-21H and 22H (see discussion below).

The correlation was refined once magnetic susceptibility and GRA density data were available at $2.5 \mathrm{~cm}$ resolution from the WRMSL, and NGR and color reflectance data were available from the NGR track and the SHMSL (see "Physical properties"). Visual inspection, comparison with core imagery, and biostratigraphic datums were used to establish and verify hole to hole correlation where track data lacked clearly identifiable features. Magnetic susceptibility and GRA density proved most useful for correlating between holes at Site U1334 (Figs. F33, F34). Features in the magnetic susceptibility and GRA density are well aligned between Holes U1334A-U1334C to $\sim 155 \mathrm{~m}$ CCSF-A. From $\sim 155$ to $222 \mathrm{~m}$ CCSF-A, GRA density data allow confident alignment of cores despite very low magnetic susceptibility values. In the interval from $\sim 222$ to $\sim 250 \mathrm{~m}$ CCSF-A (Cores 320U1334A-21H through 22H, 320-U1334B-20H through $22 \mathrm{H}$, and $320-\mathrm{U} 1334 \mathrm{C}-20 \mathrm{H}$ through $22 \mathrm{H}$ ), no features in any of the measurements available could be correlated. Several attempts to match the records did not provide convincing results. We suggest that this interval has to undergo detailed shorebased investigation to attempt the construction of a complete stratigraphic sequence. It cannot be ruled out that the apparent intensive geochemical alteration (see "Geochemistry" for discussion) in this interval has canceled out any signal detectable with the shipboard instrumentation. It is interesting to note that Cores 320-U1334A-22H, 320-U1334B-22H, and $320-\mathrm{U} 1334 \mathrm{C}-22 \mathrm{H}$ are the last APC cores in each hole and had to be recovered by overdrilling. The following cores (320-U1334A-23X, 320-U1334B-23X, and $320-\mathrm{U} 1334 \mathrm{C}-23 \mathrm{X})$ are the first $\mathrm{XCB}$ cores and are therefore very likely to be affected by severe coring disturbance. In addition to switching to the $\mathrm{XCB}$, a geochemical transition occurs in Cores 320-
U1334A-23X and 320-U1334B-23X and between Cores 320-U1334C-22H and 23X (see "Geochemistry" for discussion). It is characterized by a color change and the reappearance of a good-quality magnetic susceptibility signal. This color transition occurs at substantially different CSF depths in the three holes cored at Site U1334 (onset at $204.7 \mathrm{~m}$ CSF in Hole U1334A, $211.8 \mathrm{~m}$ CSF in Hole U1334B, and between 208 and 209 m CSF in Hole U1334C). Aligning the color transition leads to a $\sim 14 \mathrm{~m}$ core gap in Hole U1334A from 229 to 243 m CCSF-A (Figs. F33E, F34E). The top of Core 320-U1334A-22H exhibits unusually strong coring disturbance in the first two sections, suggesting that drilling conditions might have contributed to the coring gap. Biostratigraphic datum levels imply that the bottom of Core 320U1334A-22H aligns with the middle of Cores 320U1334B-22H and 320-U1334C-22H (compare Figs. F33E, F34E), suggesting that the geochemical transition does not occur at the same depth in the Site U1334 holes. A tentative comparison to the Site 1218 GRA record (Shipboard Scientific Party, 2002b) reveals no apparent correlation to Cores 320$\mathrm{U} 1334 \mathrm{~B}-22 \mathrm{H}$ and $320-\mathrm{U} 1334 \mathrm{C}-22 \mathrm{H}$ and thus suggests disturbance or interruption of the stratigraphic sequence by undetected or unidentifiable causes. Low-amplitude variations of all track data, caused presumably by geochemical alteration, hinders construction of a complete stratigraphic section throughout this interval with the shipboard data available. We decided to append the splice in the interval between $\sim 222$ and $\sim 250$ m CCSF-A. Below this depth, magnetic susceptibility and GRA data correlate well and have been used to construct a robust composite section (cf. Figs. F33, F34).

Offsets and composite depths are listed in Table T30. Following construction of the composite depth section for Site U1334, a single spliced record was assembled for the aligned cores to Section 320U1334B-30X-2 at $336.45 \mathrm{~m}$ CCSF-A (Fig. F33). The sections of core used for the splice are identified in Table T31 and displayed in Figures F33 and F34. The spliced composite section consists of almost equal proportions from all three holes.

We avoided intervals with significant disturbance or distortion and intervals where whole-round samples for interstitial water chemistry were taken (see "Paleomagnetism;" Table T11). The Site U1334 splice can be used as a sampling guide to recover a single sedimentary sequence from 0 to $336 \mathrm{~m}$ CCSFA with gaps between 222 and 250 m CCSF-A, although it is advisable to overlap a few decimeters from different holes when sampling to accommodate anticipated ongoing development of the depth scale. Stretching and compression of sedimentary 
features in aligned cores indicates distortion of the cored sequence. Because much of the distortion occurs within individual cores on depth scales of $<9 \mathrm{~m}$, it was not possible to align every single feature in the magnetic susceptibility, GRA, NGR, and color reflectance records. However, at crossover points along the splice (Table T31), care was taken to align highly identifiable features from cores in each hole.

A growth factor of 1.16 is calculated by linear regression for all holes at Site U1334, indicating a 16\% increase in CCSF-A relative to CSF depth (Fig. F35). We used this value to calculate the CCSF-B depth (see "Corrected core composite depth scale" in the "Methods" chapter) presented in Table T30 to calculate sedimentation rates and aid in the calculation of mass accumulation rates.

\section{Sedimentation rates}

All the principal biostratigraphic datums and a set of 61 paleomagnetic reversals (restricted to the APCcored section of the site) are defined in Holes U1334A-U1334C (Table T32; see "Biostratigraphy" and "Paleomagnetism") and were used in establishing age control (Fig. F14). Only the paleomagnetic reversals were used to calculate the average linear sedimentation rates (LSRs) for the APC section of Site U1334 from the CCSF-B depth scale, as depicted in Figure F14. In XCB cores, all available biostratigraphic datums were used to calculate the average LSRs.

The LSR at Site U1334 in the nannofossil oozes and chalks of lithologic Units II and III between the basement and the lower Oligocene section are $\sim 8 \mathrm{~m} / \mathrm{m}$.y., increase in the lower Oligocene to $24 \mathrm{~m} / \mathrm{m} . \mathrm{y}$., and then decrease throughout the Oligocene and Miocene to $4 \mathrm{~m} / \mathrm{m} . \mathrm{y}$. (Fig. F14).

\section{Downhole measurements}

\section{Heat flow}

Five APCT-3 downhole temperature measurements in Hole U1334B ranged from $2.82^{\circ} \mathrm{C}$ at $32.2 \mathrm{~m}$ to $5.09^{\circ} \mathrm{C}$ at $106.2 \mathrm{~m}$ (Table T33), giving a geothermal gradient of $33.0^{\circ} \mathrm{C} / \mathrm{km}$ (Fig. F36). The bottom water temperature was $1.457^{\circ} \mathrm{C}$, based on the average of the minimum temperature in the five APCT- 3 temperature profiles. Thermal conductivity under in situ conditions was estimated from laboratory-determined thermal conductivity using the method of Hyndman et al. (1974) (see "Physical properties" in the "Methods" chapter). The calculated in situ values are up to $2.2 \%$ below the measured laboratory values. Thermal resistance was then calculated by cumulatively adding the inverse of the in situ thermal con- ductivity values over depth intervals downhole (Fig. F36). A heat flow of $31.6 \mathrm{~mW} / \mathrm{m}^{2}$ was obtained from the linear fit between temperature and thermal resistance (Fig. F36) (Pribnow et al., 2000), which is an intermediate value compared to nearby sites in the global heatflow database.

\section{References}

Adkins, J.F., and Schrag, D.P., 2003. Reconstructing Last Glacial Maximum bottom water salinities from deep-sea sediment pore fluid profiles. Earth Planet Sci. Lett., 216:109-123. doi:10.1016/S0012-821X(03)00502-8

Amante, C., and Eakins, B.W., 2008. ETOPO1 1 Arc-Minute Global Relief Model: Procedures, Data Sources and Analysis: Washington, DC (DOC/NOAA/NESDIS/NGDC).

Barron, J.A., 1985. Late Eocene to Holocene diatom biostratigraphy of the equatorial Pacific Ocean, Deep Sea Drilling Project Leg 85. In Mayer, L., Theyer, F., Thomas, E., et al., Init. Repts. DSDP, 85: Washington, DC (U.S. Govt. Printing Office), 413-456. doi:10.2973/ dsdp.proc.85.108.1985

Barron, J.A. 2006. Diatom biochronology for the early Miocene of the equatorial Pacific. Stratigraphy, 2(4):281-30.

Barron, J.A., Fourtanier, E., and Bohaty, S.M., 2004. Oligocene and earliest Miocene diatom biostratigraphy of ODP Leg 199 Site 1220, equatorial Pacific. In Wilson, P.A., Lyle, M., Janecek, T.R., and Firth, J.V. (Eds.), Proc. ODP, Sci. Results, 199: College Station (Ocean Drilling Program), 1-25. doi:10.2973/

odp.proc.sr.199.204.2004

Berggren, W.A., Kent, D.V., Swisher, C.C., III, and Aubry, M.-P., 1995. A revised Cenozoic geochronology and chronostratigraphy. In Berggren, W.A., Kent, D.V., Aubry, M.-P., and Hardenbol, J. (Eds.), Geochronology, Time Scales and Global Stratigraphic Correlation. Spec. Publ._SEPM (Soc. Sediment. Geol.), 54:129-212.

Blaj, T., Backman, J., and Raffi, I., 2009. Late Eocene to Oligocene preservation history and biochronology of calcareous nannofossils from paleo-equatorial Pacific Ocean sediments. Rivista Italiana Paleontologia e Stratigrafia, 115(1):67-84.

Bohaty, S.M., Pälike, H., Ridgwell, A., Zachos, J.C., and Lear, C.H., 2008. Timing and significance of a global deep-sea dissolution event during the Eocene-Oligocene transition. Eos Trans. AGU, Fall Meet. Suppl., Abstract PP41D-1487. http://adsabs.harvard.edu/abs/ 2008AGUFMPP41D1487B

Busch, W.H., Vanden Berg, M.D., and Masau, P.E., 2006. Velocity and density of Paleogene equatorial sediments: variation with sediment composition. In Wilson, P.A., Lyle, M., and Firth, J.V. (Eds.), Proc. ODP, Sci. Results, 199: College Station, TX (Ocean Drilling Program), 131. doi:10.2973/odp.proc.sr.199.226.2006

Coxall, H.K., Huber, B.T., and Pearson, P.N., 2003. Origin and morphology of the Eocene planktonic foraminifer Hantkenina. Journal of Foraminiferal Research, 33(3):237-261. doi:10.2113/33.3.237 
Coxall, H.K., Wilson, P.A., Pälike, H., Lear, C.H., and Backman, J., 2005. Rapid stepwise onset of Antarctic glaciation and deeper calcite compensation in the Pacific Ocean. Nature (London, U. K.), 433(7021):53-57. doi:10.1038/nature03135

DeConto, R.M., Pollard, D., Wilson, P.A., Palike, H., Lear, C.H., and Pagani, M., 2008. Thresholds for Cenozoic bipolar glaciation. Nature (London, U. K.), 455(7213):652-656. doi:10.1038/nature07337

Engebretson, D.C., Cox, A., and Gordon, R.G., 1985. Relative Motions between Oceanic and Continental Plates in the Pacific Basin. Spec. Pap.-Geol. Soc. Am., 206.

Hays, J.D., et al., 1972. Init. Repts. DSDP, 9: Washington, DC (U.S. Govt. Printing Office). doi:10.2973/ dsdp.proc.9.1972

Hyndman, R.D., Erickson, A.J., and Von Herzen, R.P., 1974. Geothermal measurements on DSDP Leg 26. In Davies, T.A., Luyendyk, B.P., et al., Init. Repts. DSDP, 26: Washington, DC (U.S. Govt. Printing Office), 451-463. doi:10.2973/dsdp.proc.26.113.1974

Kennett, J.P., and Shackleton, N.J., 1976. Oxygen isotopic evidence for the development of the psychrosphere 38 Myr ago. Nature (London, U. K.), 260(5551):513-515. doi:10.1038/260513a0

Knappenberger, M., 2000. Sedimentation rates and Pacific plate motion calculated using seismic cross sections of the Neogene equatorial sediment bulge [M.Sc. thesis]. Boise State Univ., Idaho.

Koppers, A.A.P., Phipps Morgan, J., Morgan, J.W., and Staudigel, H., 2001. Testing the fixed hotspot hypothesis using ${ }^{40} \mathrm{Ar} /{ }^{39} \mathrm{Ar}$ age progressions along seamount trails. Earth Planet. Sci. Lett., 185(3-4):237-252. doi:10.1016/ S0012-821X(00)00387-3

Lear, C.H., Bailey, T.R., Pearson, P.N., Coxall, H.K., and Rosenthal, Y., 2008. Cooling and ice growth across the Eocene-Oligocene transition. Geology, 36(3):251-254. doi:10.1130/G24584A.1

Liu, Z., Pagani, M., Zinniker, D., DeConto, R., Huber, M., Brinkhuis, H., Shah, S.R., Leckie, R.M., and Pearson, A., 2009. Global cooling during the Eocene-Oligocene climate transition. Science, 323(5918):1187-1190. doi:10.1126/science.1166368

Lyle, M., Liberty, L., Moore, T.C., Jr., and Rea, D.K., 2002. Development of a seismic stratigraphy for the Paleogene sedimentary section, central tropical Pacific Ocean. In Lyle, M., Wilson, P.A., Janecek, T.R., et al., Proc. ODP, Init. Repts., 199: College Station, TX (Ocean Drilling Program), 1-21. doi:10.2973/ odp.proc.ir.199.104.2002

Lyle, M.W., Pälike, H., Moore, T.C., Mitchell, N., and Backman, J., 2006. Summary Report of $R / V$ Roger Revelle Site Survey AMAT03 to the IODP Environmental Protection and Safety Panel (EPSP) in Support for Proposal IODP626: Southampton, U.K. (Univ. Southampton). http:// eprints.soton.ac.uk/45921/

Lyle, M., Wilson, P.A., Janecek, T.R., et al., 2002. Proc. ODP, Init. Repts., 199: College Station, TX (Ocean Drilling Program). doi:10.2973/odp.proc.ir.199.2002

Mackensen, A., Grobe, H., Kuhn, G., and Fütterer, D.K., 1990. Benthic foraminiferal assemblages from the east- ern Weddell Sea between $68^{\circ}$ and $73^{\circ} \mathrm{S}$ : distribution, ecology and fossilization potential. Mar. Micropaleontol., 16(3-4):241-283. doi:10.1016/0377-8398(90)90006-8

Mayer, L.A., Shipley, T.H., Theyer, F., Wilkens, R.H., and Winterer, E.L., 1985. Seismic modeling and paleoceanography at Deep Sea Drilling Project Site 574. In Mayer, L., Theyer, F., Thomas, E., et al., Init. Repts. DSDP, 85: Washington, DC (U.S. Govt. Printing Office), 947-970. doi:10.2973/dsdp.proc.85.132.1985

Miller, K.G., Wright, J.D., and Fairbanks, R.G., 1991. Unlocking the ice house: Oligocene-Miocene oxygen isotopes, eustasy, and margin erosion. J. Geophys. Res., 96(B4):6829-6848. doi:10.1029/90JB02015

Müller, R.D., Roest, W.R., Royer, J.-Y., Gahagan, L.M., and Sclater, J.G., 1997. Digital isochrons of the world's ocean floor. J. Geophys. Res., 102(B2):3211-3214. doi:10.1029/96JB01781

Pälike, H., Moore, T., Backman, J., Raffi, I., Lanci, L., Parés, J.M., and Janecek, T., 2005. Integrated stratigraphic correlation and improved composite depth scales for ODP Sites 1218 and 1219. In Wilson, P.A., Lyle, M., and Firth, J.V. (Eds.), Proc. ODP, Sci. Results, 199: College Station, TX (Ocean Drilling Program), 1-41. doi:10.2973/ odp.proc.sr.199.213.2005

Pälike, H., Lyle, M.W., Ahagon, N., Raffi, I., Gamage, K., and Zarikian, C.A., 2008. Pacific equatorial age transect. IODP Sci. Prosp., 320/321. doi:10.2204/ iodp.sp.320321.2008

Pälike, H., Frazier, J., and Zachos, J.C., 2006a. Extended orbitally forced palaeoclimatic records from the equatorial Atlantic Ceara Rise. Quat. Sci. Rev., 25(23-24):31383149. doi:10.1016/j.quascirev.2006.02.011

Pälike, H., Norris, R.D., Herrle, J.O., Wilson, P.A., Coxall, H.K., Lear, C.H., Shackleton, N.J., Tripati, A.K., and Wade, B.S., 2006b. The heartbeat of the Oligocene climate system. Science, 314(5807):1894-1898. doi:10.1126/science.1133822

Pearson, P.N., McMillan, I.K., Wade, B.S., Dunkley Jones, T., Coxall, H.K., Bown, P.R., and Lear, C.H., 2008. Extinction and environmental change across the Eocene-Oligocene boundary in Tanzania. Geology, 36(2):179-182. doi:10.1130/G24308A.1

Petronotis, K.E., 1991. Paleomagnetic studies of the skewness of Pacific plate marine magnetic anomalies 2532R: implications for anomalous skewness and the motion of the Pacific plate and hotspots [Ph.D. thesis]. Northwestern Univ., Evanston, IL.

Petronotis, K.E., Gordon, R.G., and Acton, G.D., 1994. A 57 Ma Pacific plate paleomagnetic pole determined from a skewness analysis of crossings of marine magnetic anomaly 25r. Geophys. J. Int., 118(3):529-554. doi:10.1111/j.1365-246X.1994.tb03983.x

Pribnow, D.F.C., Kinoshita, M., and Stein, C.A., 2000. Thermal Data Collection and Heat Flow Recalculations for ODP Legs 101-180: Hanover, Germany (Inst. Joint Geosci. Res., Inst. Geowiss. Gemeinschaftsauf. [GGA]). http:// www-odp.tamu.edu/publications/heatflow/ ODPReprt.pdf

Raffi, I., Backman, J., Fornaciari, E., Pälike, H., Rio, D., Lourens, L., and Hilgen, F., 2006. A review of calcareous 
nannofossil astrobiochronology encompassing the past 25 million years. Quat. Sci. Rev., 25(23-24):3113-3137. doi:10.1016/j.quascirev.2006.07.007

Sager, W.W., and Pringle, M.S., 1988. Mid-Cretaceous to early Tertiary apparent polar wander path of the Pacific plate. J. Geophys. Res., [Solid Earth], 93(B10):1175311771. doi:10.1029/JB093iB10p11753

Schmiedl, G., Mackensen, A., and Müller, P.J., 1997. Recent benthic foraminifera from the eastern South Atlantic Ocean: dependence on food supply and water masses. Mar. Micropaleontol., 32(3-4):249-287. doi:10.1016/ S0377-8398(97)00023-6

Shackleton, N.J., Hall, M.A., Raffi, I., Tauxe, L., and Zachos, J., 2000. Astronomical calibration age for the Oligocene-Miocene boundary. Geology, 28(5):447-450. doi:10.1130/00917613(2000)28<447:ACAFTO>2.0.CO;2

Shipboard Scientific Party, 2002a. Leg 199 summary. In Lyle, M., Wilson, P.A., Janecek, T.R., et al., Proc. ODP, Init. Repts., 199: College Station, TX (Ocean Drilling Program), 1-87. doi:10.2973/odp.proc.ir.199.101.2002

Shipboard Scientific Party, 2002b. Site 1218. In Lyle, M., Wilson, P.A., Janecek, T.R., et al., Proc. ODP, Init. Repts., 199: College Station, TX (Ocean Drilling Program), 1125. doi:10.2973/odp.proc.ir.199.111.2002

Takata, H., and Nomura, R., 2005. Data report: Oligocene benthic foraminifers from the eastern equatorial Pacific, Sites 1218 and 1219, ODP Leg 199. In Wilson, P.A., Lyle, M., and Firth, J.V. (Eds.), Proc. ODP, Sci. Results, 199: College Station, TX (Ocean Drilling Program), 1-26. doi:10.2973/odp.proc.sr.199.224.2005

Thomas, E., 1985. Late Eocene to recent deep-sea benthic foraminifers from the central equatorial Pacific Ocean. In Mayer, L., Theyer, F., et al., Init. Repts. DSDP, 85: Washington (U.S. Govt. Printing Office). doi:10.2973/ dsdp.proc.85.117.1985 van Andel, T.H., 1975. Mesozoic/Cenozoic calcite compensation depth and the global distribution of calcareous sediments. Earth Planet. Sci. Lett., 26(2):187-194. doi:10.1016/0012-821X(75)90086-2

van Morkhoven, F.P.C.M., Berggren, W.A., and Edwards, A.S., 1986. Cenozoic Cosmopolitan Deep-Water Benthic Foraminifera. Bull. Cent. Rech. Explor--Prod. Elf-Aquitaine, Mem. 11.

Wade, B.S., and Pälike, H., 2004. Oligocene climate dynamics. Paleoceanography, 19(4)PA4019. doi:10.1029/ 2004PA001042

Wade, B.S., and Pearson, P.N., 2008. Planktonic foraminiferal turnover, diversity fluctuations and geochemical signals across the Eocene/Oligocene boundary in Tanzania. Mar. Micropaleontol., 68(3-4):244-255. doi:10.1016/ j.marmicro.2008.04.002

Wei, W., and Wise, S.W., Jr., 1989. Paleogene calcareous nannofossil magnetobiochronology: results from South Atlantic DSDP Site 516. Mar. Micropaleontol., 14(13):119-152. doi:10.1016/0377-8398(89)90034-0

Wilson, P.A., Lyle, M., and Firth, J.V. (Eds.), 2006. Proc. ODP, Sci. Results, 199: College Station, TX (Ocean Drilling Program). doi:10.2973/odp.proc.sr.199.2006

Young, J.R., 1999. Neogene. In Bown, P.R. (Ed.), Calcareous Nannofossil Biostratigraphy: Dordrecht, The Netherlands (Kluwer Academic Publ.), 225-265.

Zachos, J.C., Quinn, T.M., and Salamy, K.A., 1996. Highresolution $\left(10^{4}\right.$ years $)$ deep-sea foraminiferal stable isotope records of the Eocene-Oligocene climate transition. Paleoceanography, 11(3):251-266. doi:10.1029/ 96PA00571

Zachos, J.C., Shackleton, N.J., Revenaugh, J.S., Pälike, H., and Flower, B.P., 2001. Climate response to orbital forcing across the Oligocene-Miocene boundary. Science, 292(5515):274-278. doi:10.1126/science.1058288

Publication: 30 October 2010 MS 320321-106 
Figure F1. A. ETOPO1 (Amante and Eakins, 2008) bathymetric overview map of Site U1334 and PEAT drilling locations, with previous ODP and DSDP sites. B. Swath map bathymetry for Site U1334 region from the AMAT03 site survey. Black labels $=$ seismic shotpoints, white labels $=$ bathymetric contours. White line $=$ survey Line 1, purple line = survey Line 6. F.Z. = fracture zone.
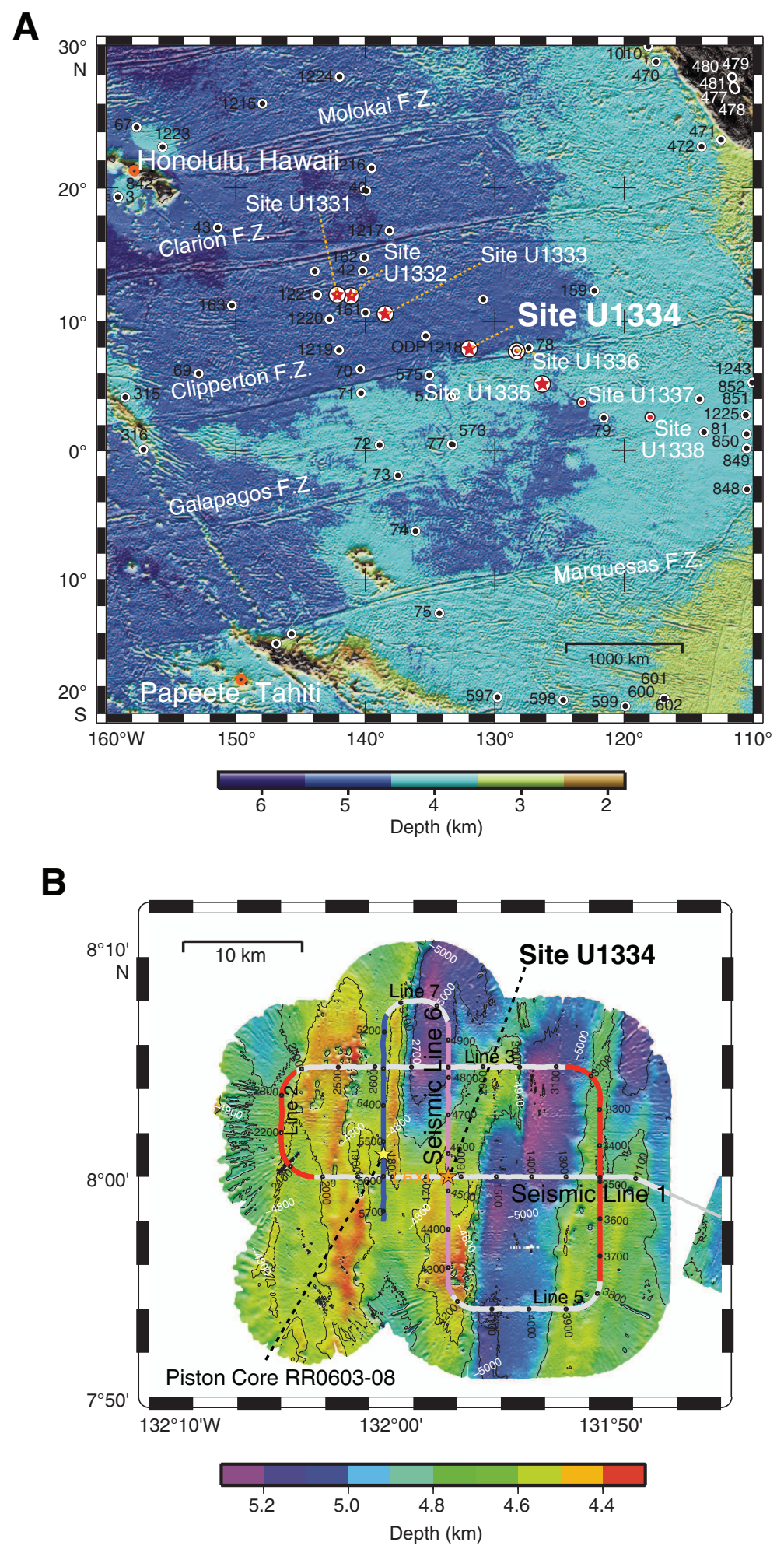
Figure F2. Seismic reflection profile PEAT-4C (Site U1334) Line 1 from the 48-channel seismic reflection survey, annotated in shotpoints (Lyle et al., 2006). Data are filtered, stacked, and migrated. Site was located where basal reflections appeared less strong to minimize possible cherts. Tentative conversion from two-way traveltime to depth uses velocity model of Busch et al. (2006). All times are Universal Time Coordinated (UTC). $\mathrm{TD}=$ total depth

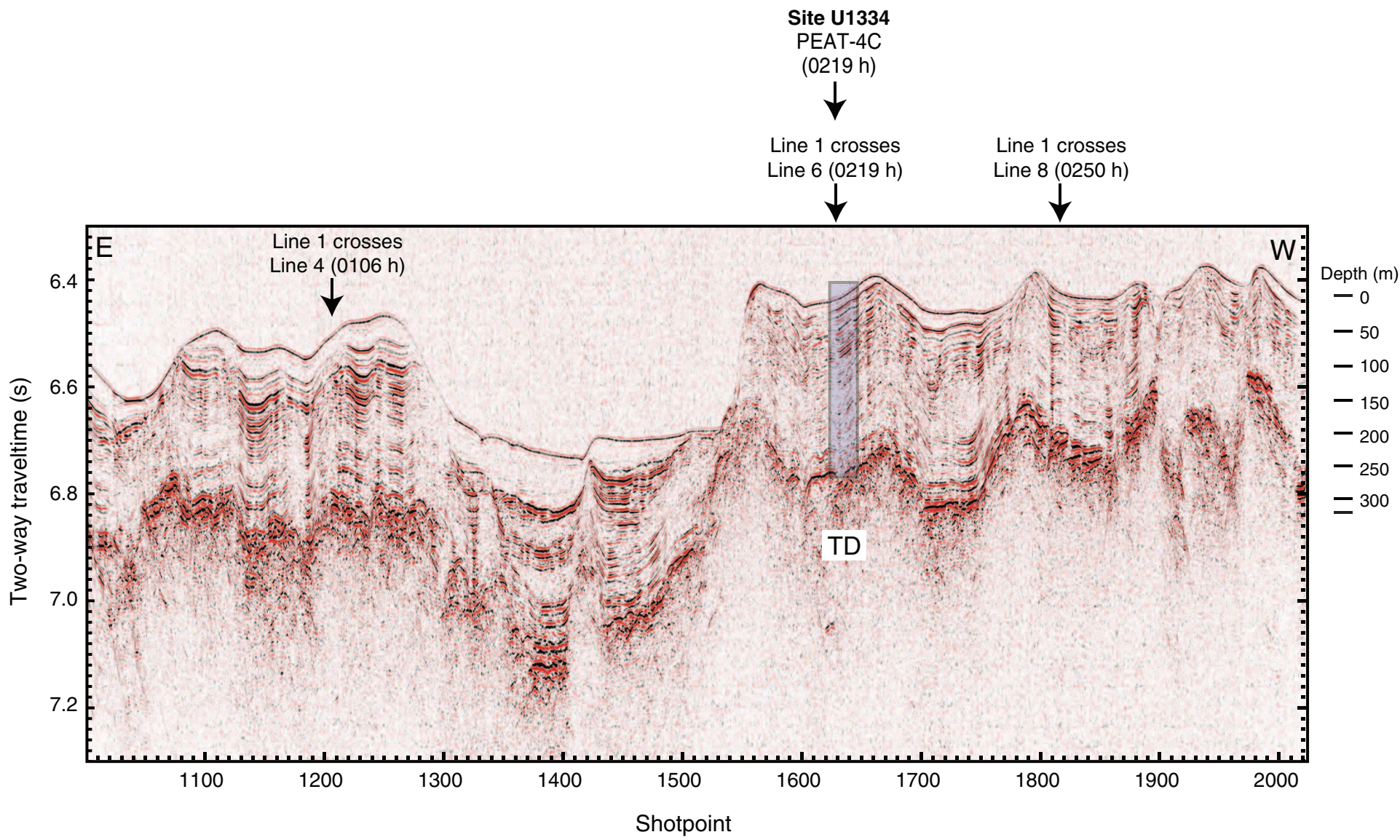


Figure F3. Correlation of Eocene/Oligocene (E/O) boundary from Pearson et al. (2008) with Site 1218 data (Coxall et al., 2005; Pälike et al., 2006b) and astronomical parameters. Amplitude min = 1.2 m.y. orbital amplitude minimum and 400 k.y. eccentricity minimum (green bar). MAR = mass accumulation rate, ETP = Eccentricity-Tilt-Precession mix.

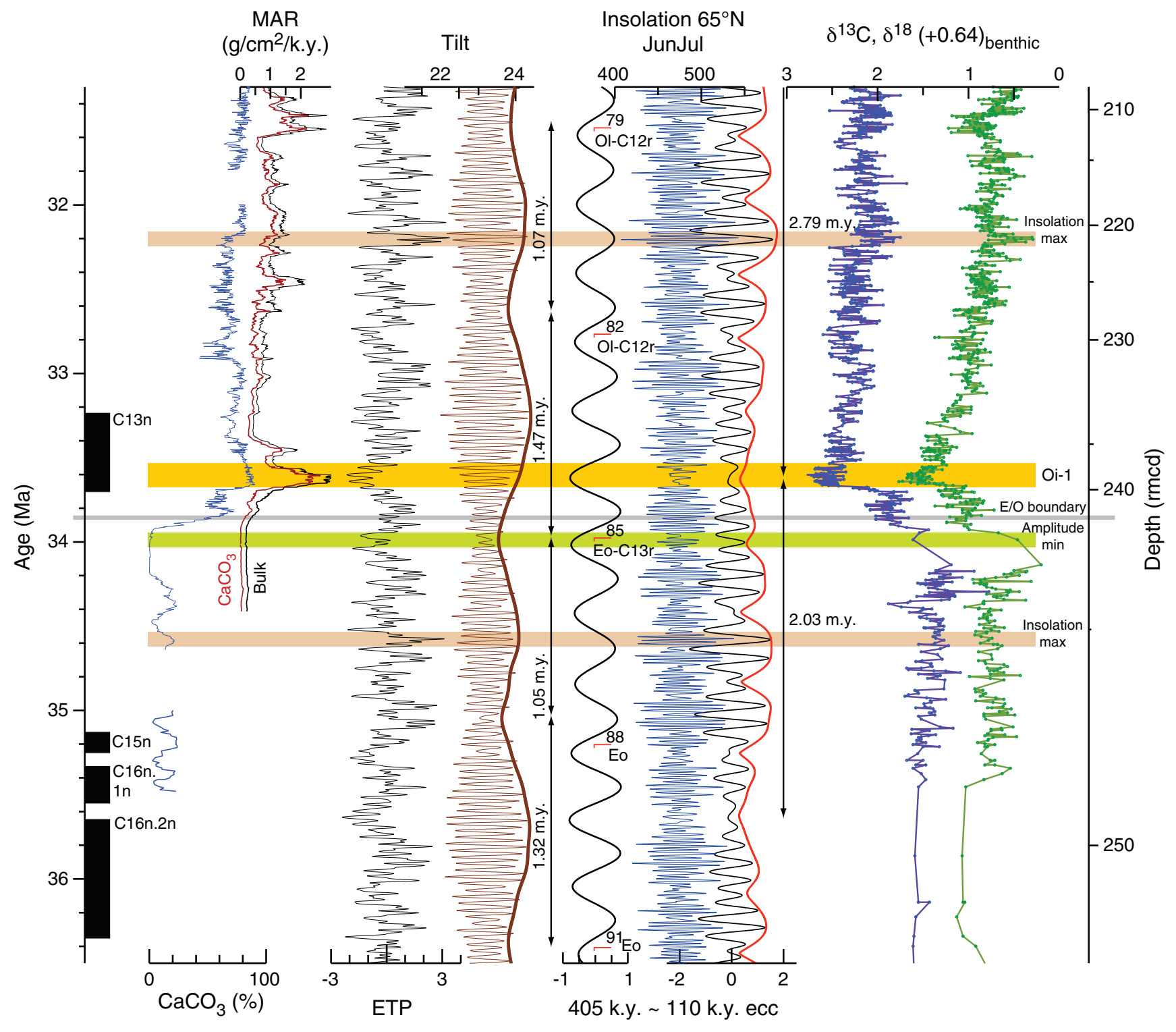


Figure F4. Site U1334 summary. At Site U1334, planktonic foraminifer Zones O2, O3, and O6 are informally divided into an upper and lower part using the base of Paragloborotalia opima and top of Subbotina angiporoides and the base of Paragloborotalia pseudokugleri, respectively.

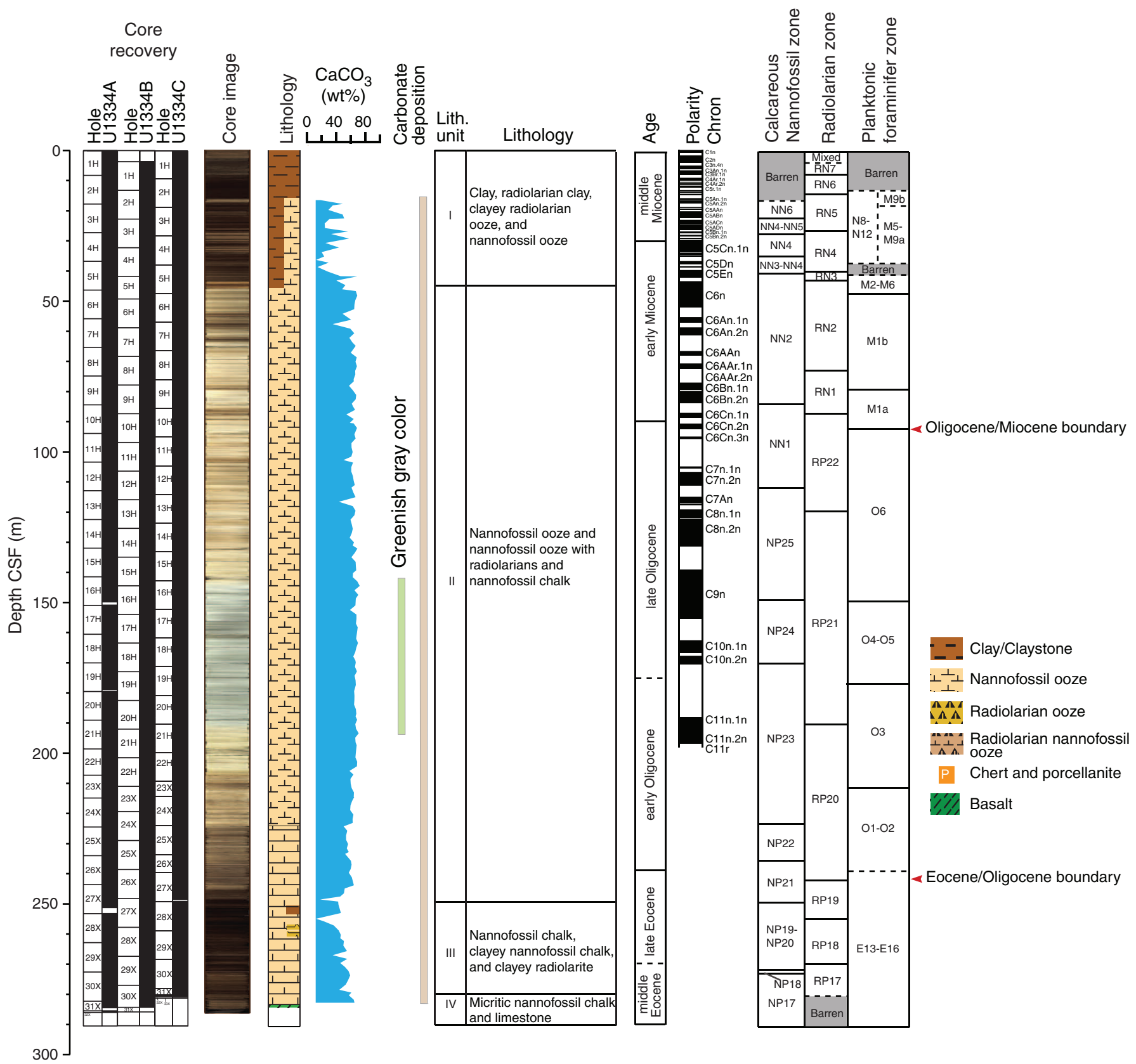


Figure F5. Lithologic summary, Site U1334. $\mathrm{L}^{*}, \mathrm{~b}^{*}=$ reflectance value of sediment as defined in the LAB color model.

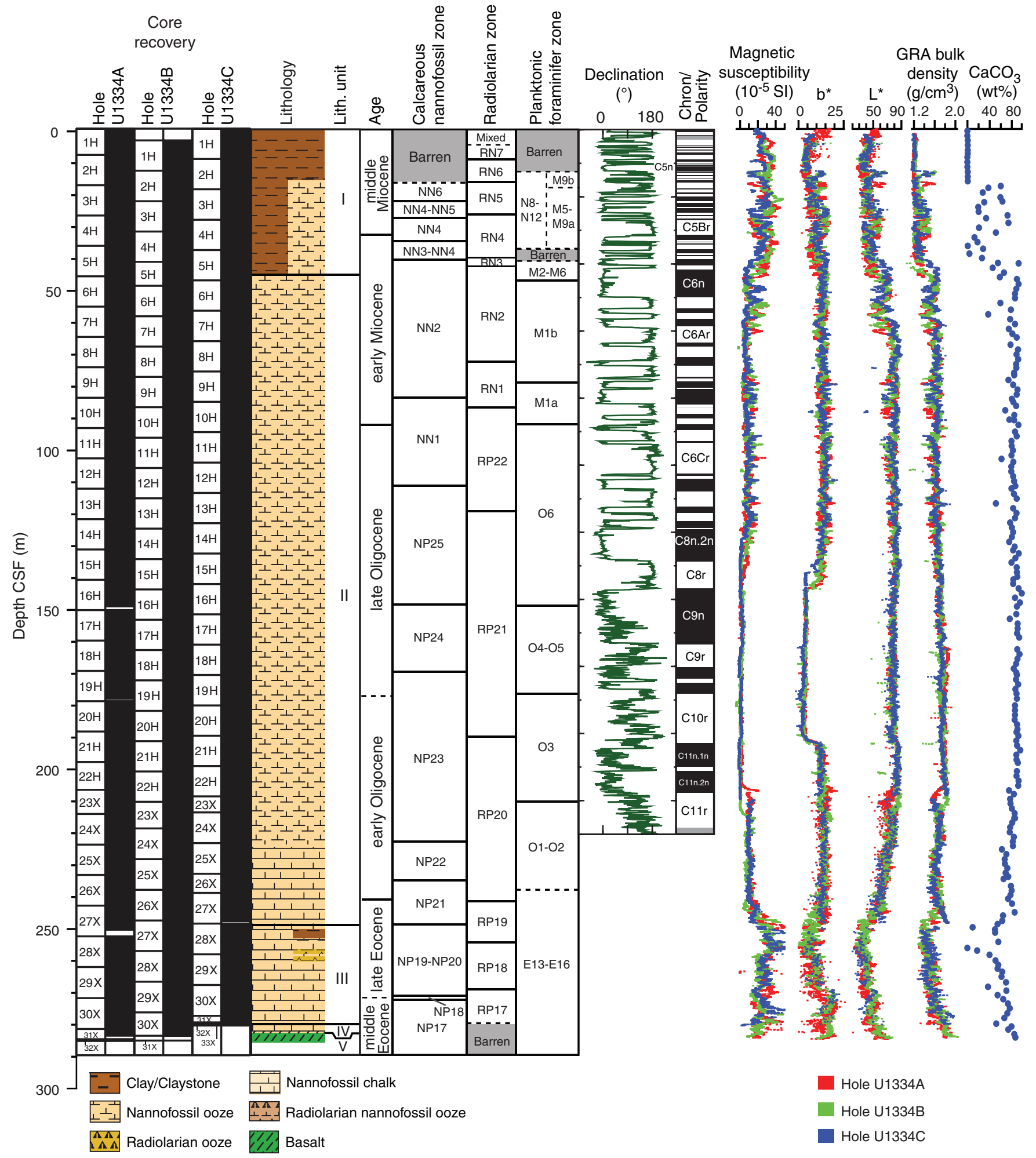


Figure F6. Calcium carbonate $\left(\mathrm{CaCO}_{3}\right)$, total carbon (TC), inorganic carbon (IC), and total organic carbon (TOC) determined by normal and acidification methods in sediments from Hole U1334A. (See "Lithostratigraphy" for information on unit boundaries.)

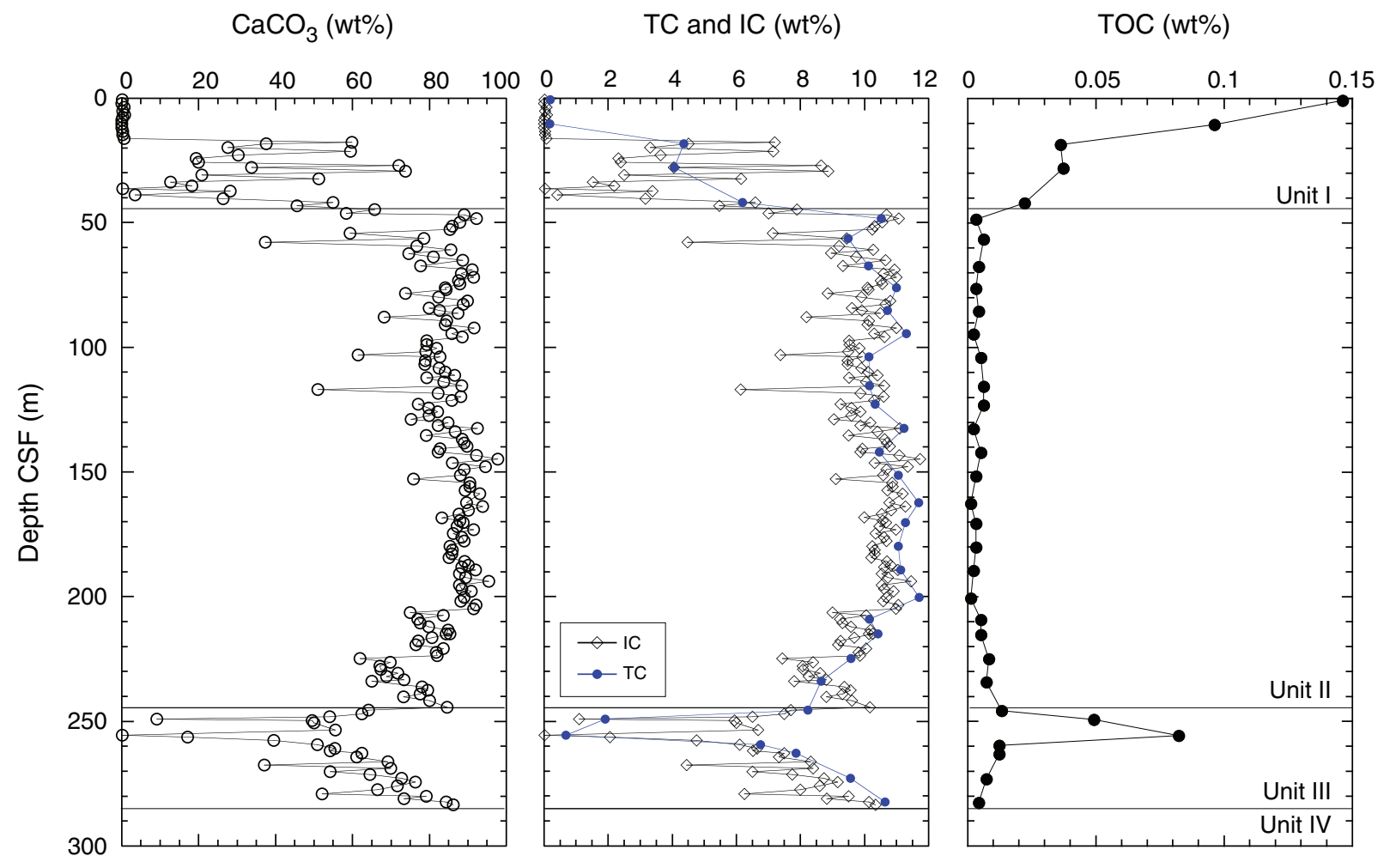


Figure F7. Color reflectance and magnetic susceptibility, Hole U1334A. Line scan images from Cores 320U1334A-15H through $16 \mathrm{H}$ and $21 \mathrm{H}$ through $23 \mathrm{X}$ highlight observed color changes. $\mathrm{L}^{*}, \mathrm{a}^{*}, \mathrm{~b}^{*}=$ reflectance value of sediment as defined in the LAB color model.

Hole U1334A

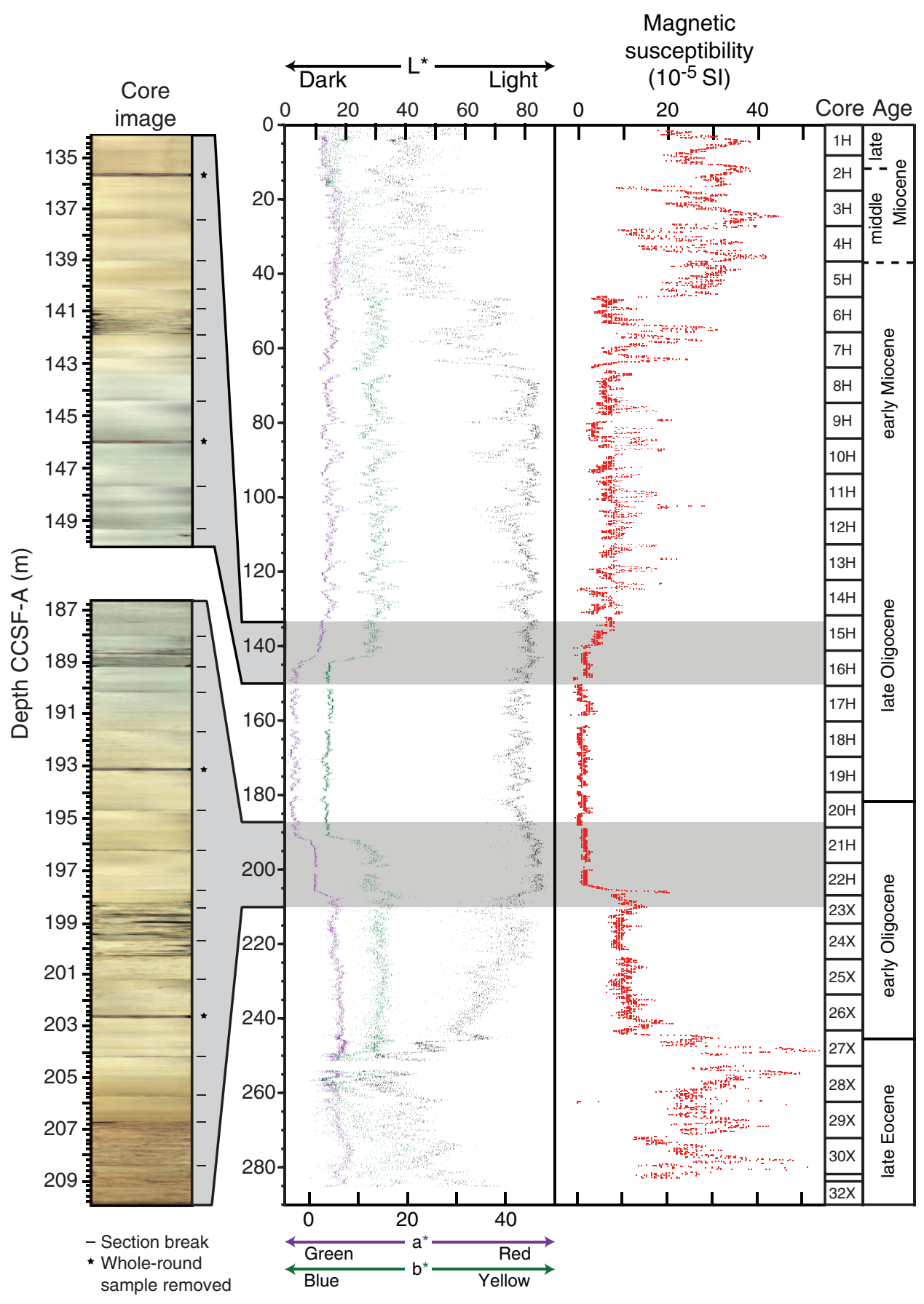


Figure F8. Subtle color variations in Sections 320-U1334B-8H-3 through 8H-5 and $11 \mathrm{H}-2$ and $11 \mathrm{H}-3$. Pie charts show the compositions of sediments based on smear slide descriptions.
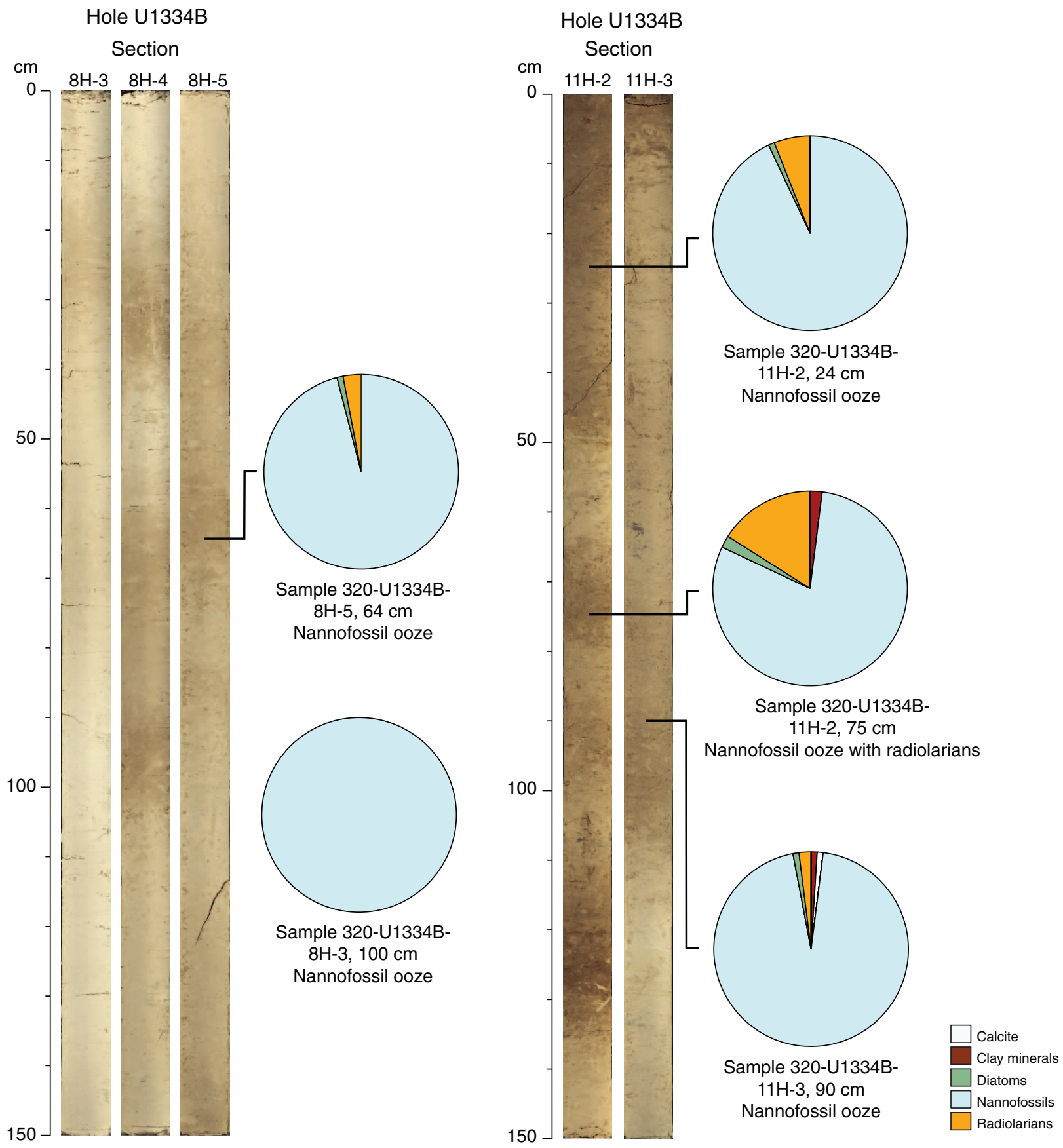
Figure F9. Line scan images of Oligocene-Miocene transition. A. Hole U1334A. B. Hole U1334B. C. Hole U1334C. $\mathrm{L}^{*}=$ reflectance value of sediment as defined in the $\mathrm{LAB}$ color model. $\mathrm{FO}=$ first occurrence, $\mathrm{LO}=$ last occurrence.

A

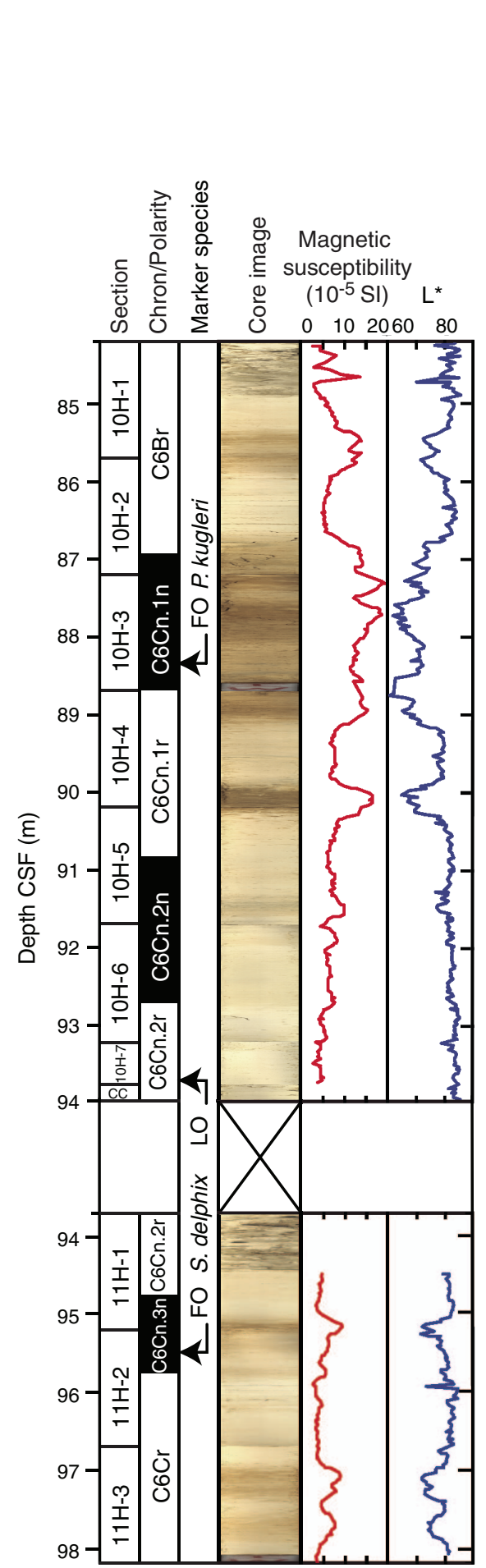

B

Hole U1334A
Hole U1334B

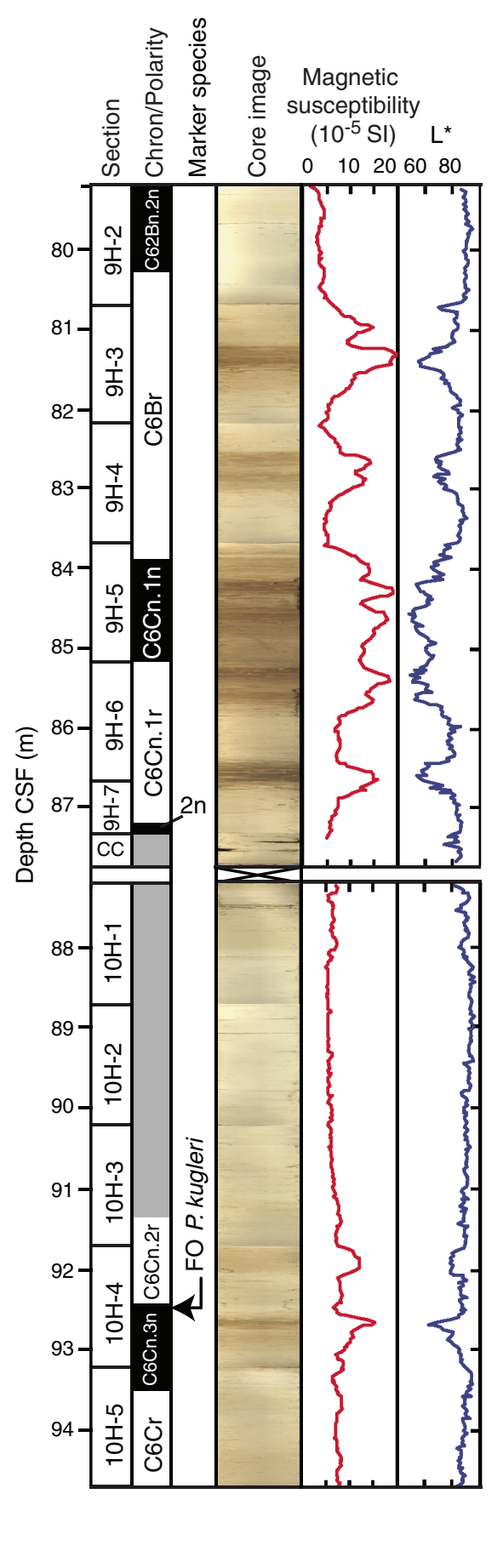

C Hole U1334C

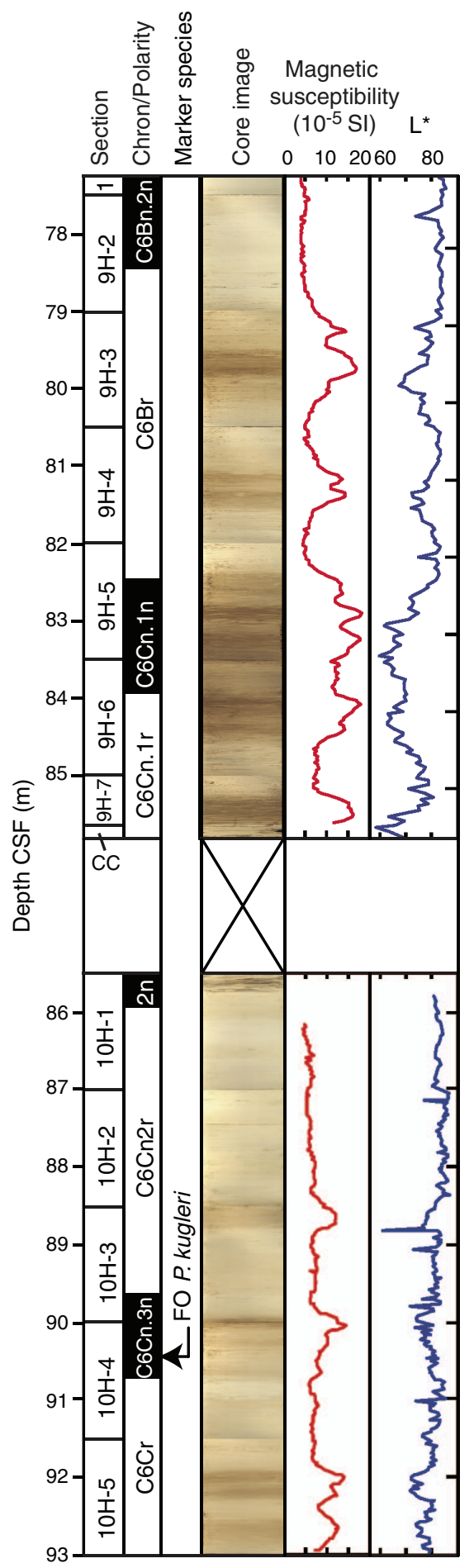


Figure F10. Line scan images of Eocene-Oligocene transition. A. Hole U1334A. B. Hole U1334B. C. Hole U1334C. Images were manipulated by applying a shadow-highlight adjustment to the whole image for better visual inspection of the darker strata. Nonmanipulated images are shown in Figure F12. $\mathrm{L}^{*}=$ reflectance value of sediment as defined in the LAB color model.

A

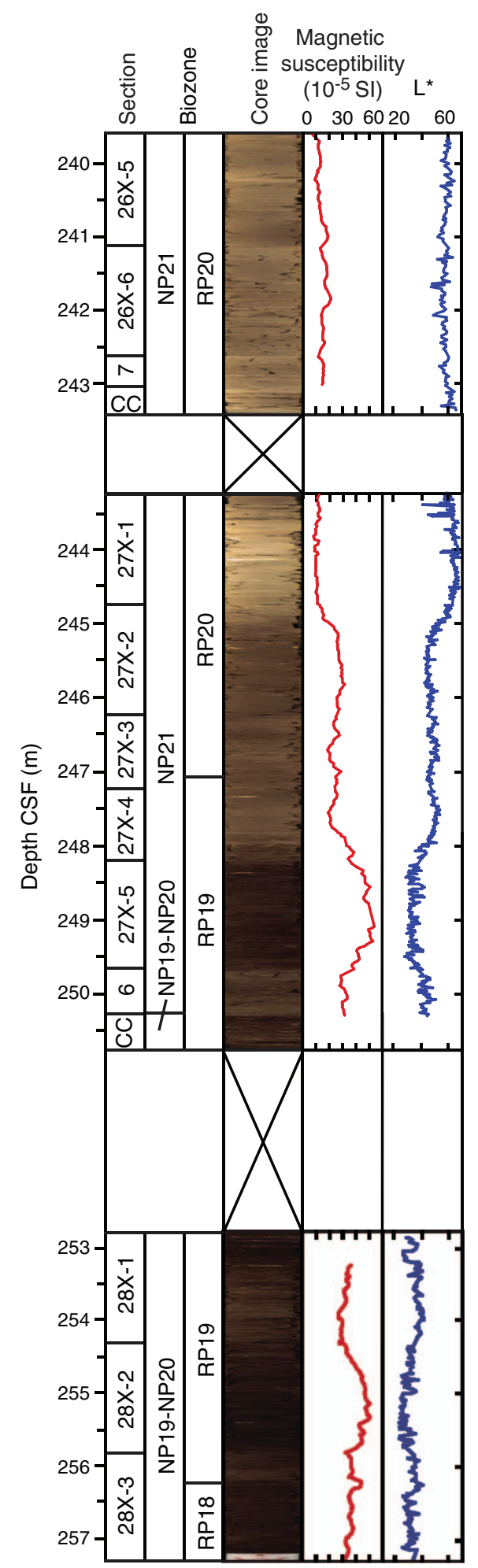

B

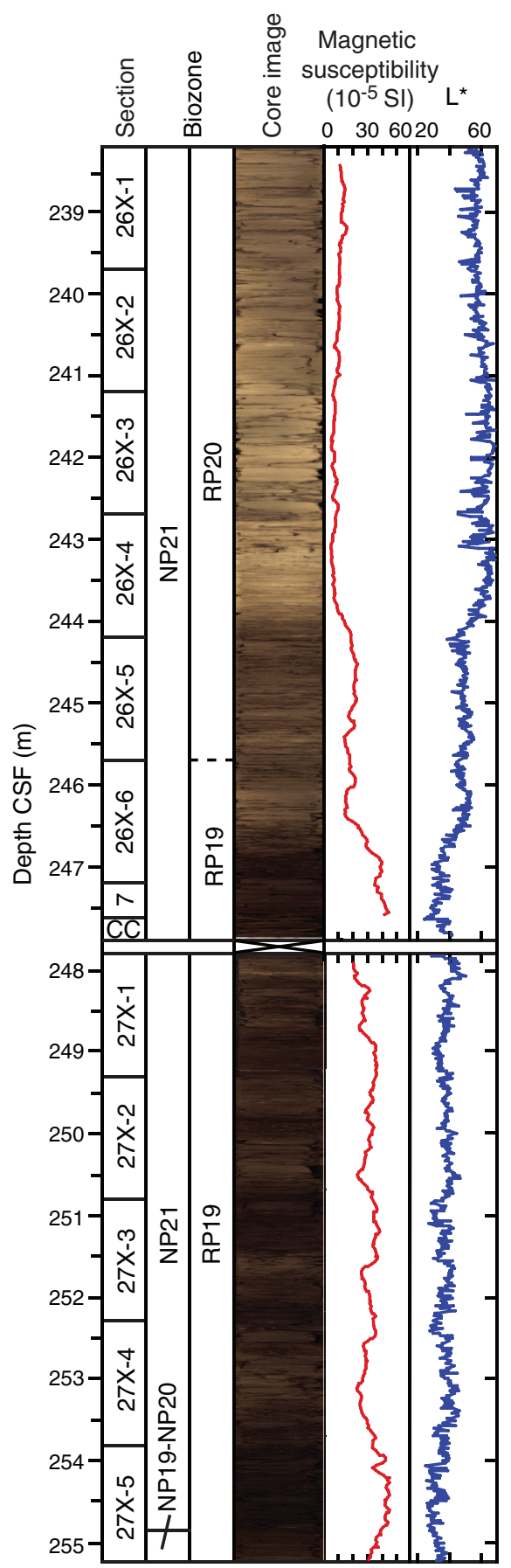

C

Hole U1334C

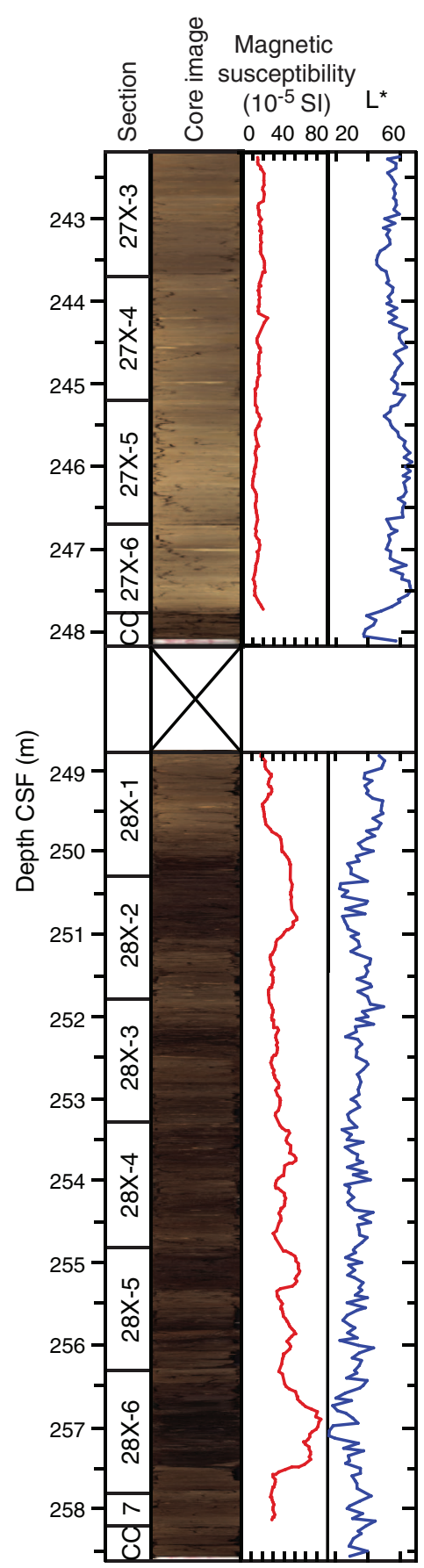


Figure F11. Photomicrographs of smear slides taken across the Eocene-Oligocene transition, Site U1334. Panels are arranged in stratigraphic order (increasing age top to bottom). See "Site U1334 smear slides" in "Core descriptions" for full descriptions. Left image $=$ plane-polarized light, right image $=$ cross-polarized light. A. Nannofossil ooze (Sample 320-U1334B-26X-5, $41 \mathrm{~cm}$ ). B. Clayey nannofossil ooze with radiolarians (Sample 320-U1334B-26X-6, $141 \mathrm{~cm}$ ). C. Nannofossil ooze with clay (Sample 320-U1334B-27X-4, $26 \mathrm{~cm}$ ). D. Radiolarian claystone (Sample 320-U1334B-27X-5, $77 \mathrm{~cm}$ ).
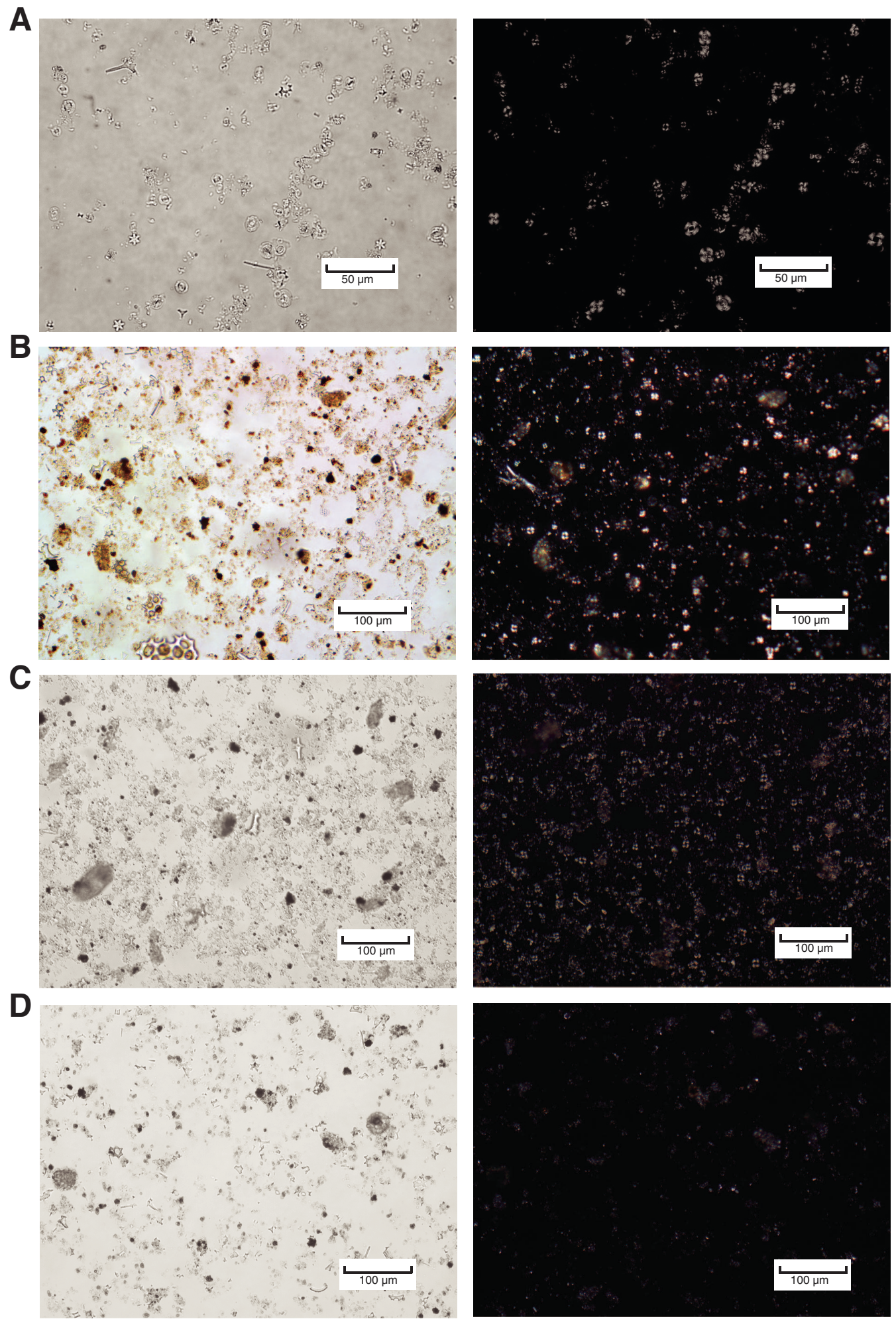
Figure F12. Line scan images of Eocene-Oligocene transition. Images are not adjusted to allow for direct comparison between the two sites. A. Hole U1334A. B. Hole U1334B. $\mathrm{L}^{*}=$ reflectance value of sediment as defined in the LAB color model.

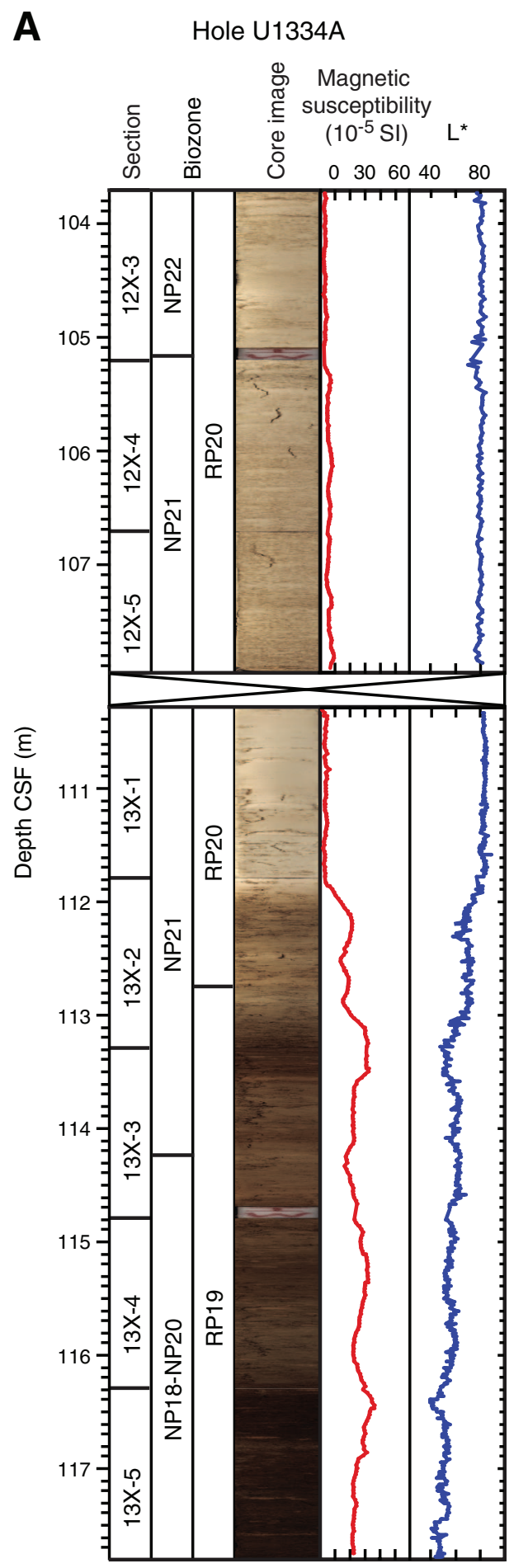

B

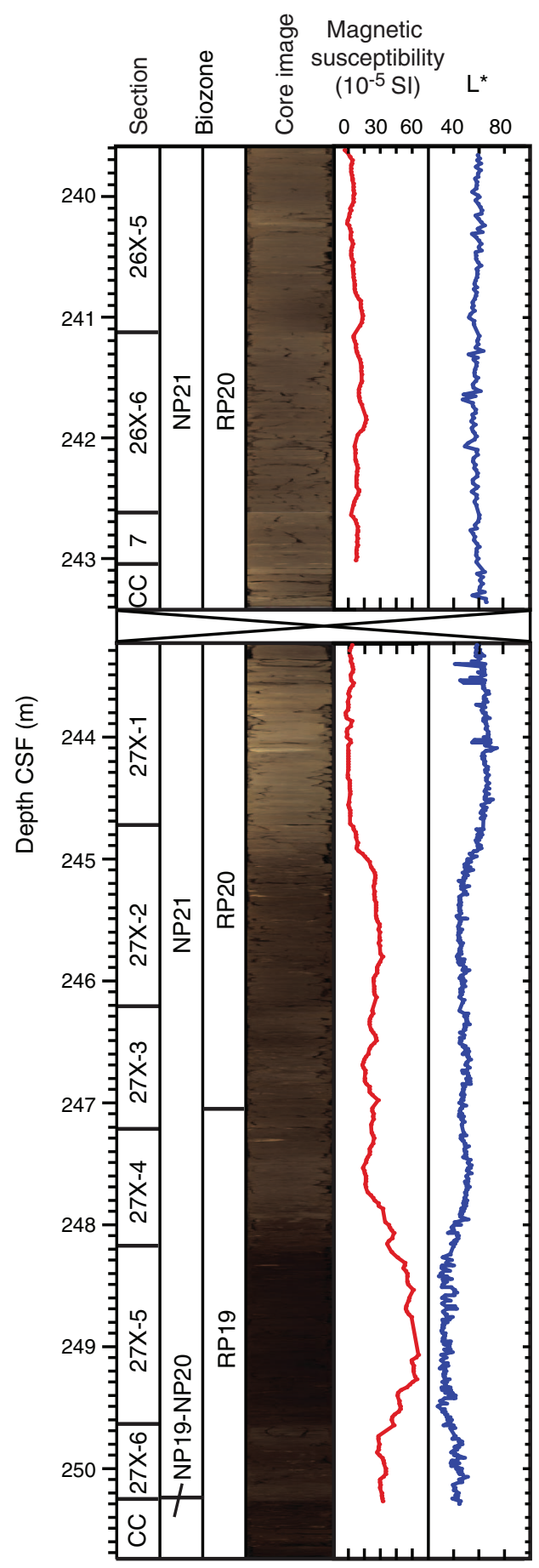


Figure F13. Integrated calcareous and siliceous microfossil biozonation, Site U1334. Calcareous microfossil zonation was limited by the presence of extensive barren intervals; dashed zonal boundaries indicate stratigraphic extent of calcareous microfossil assemblages consistent with a particular zonal assignment.

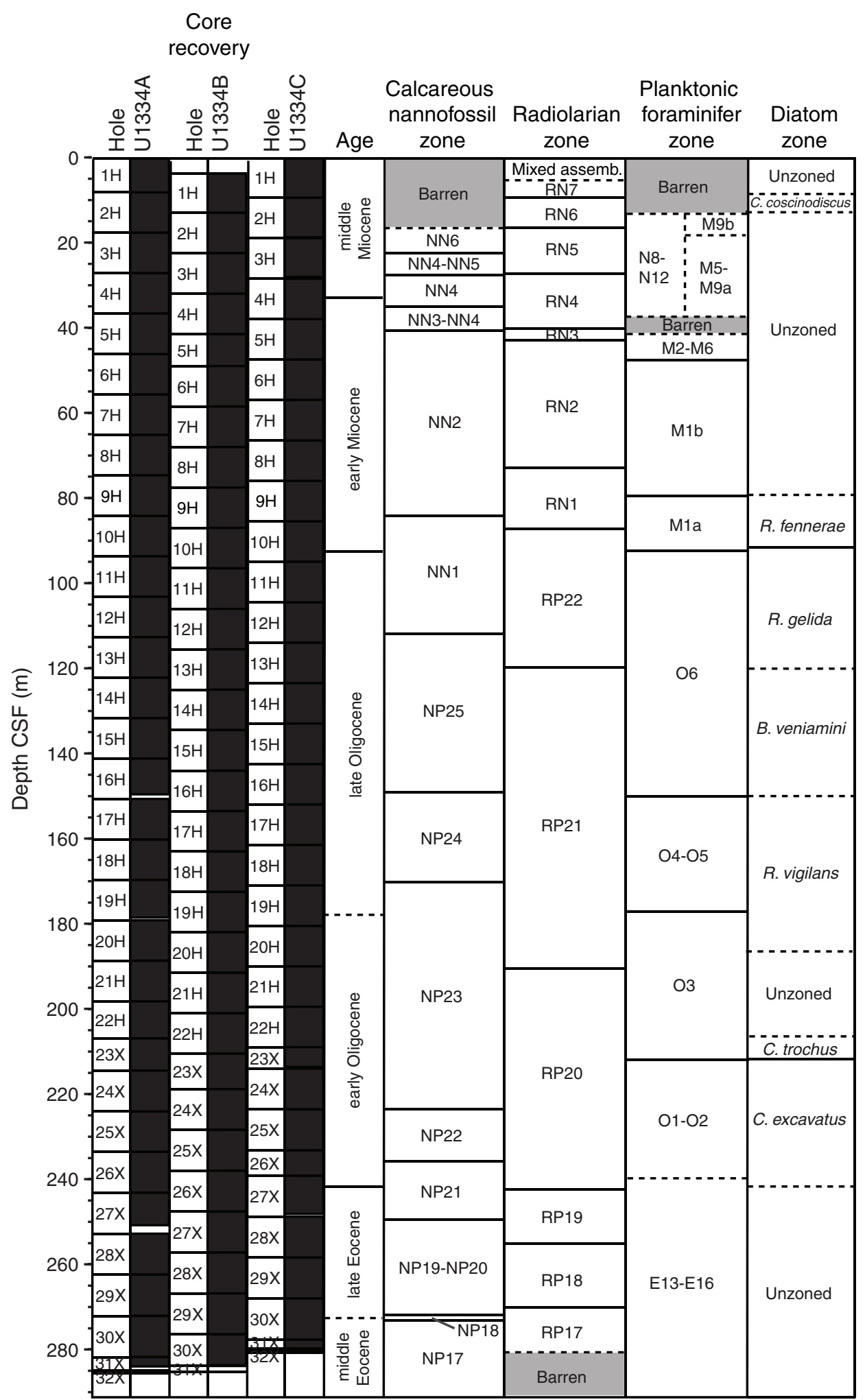


Figure F14. Linear sedimentation rates and chronostratigraphic markers, Site U1334.

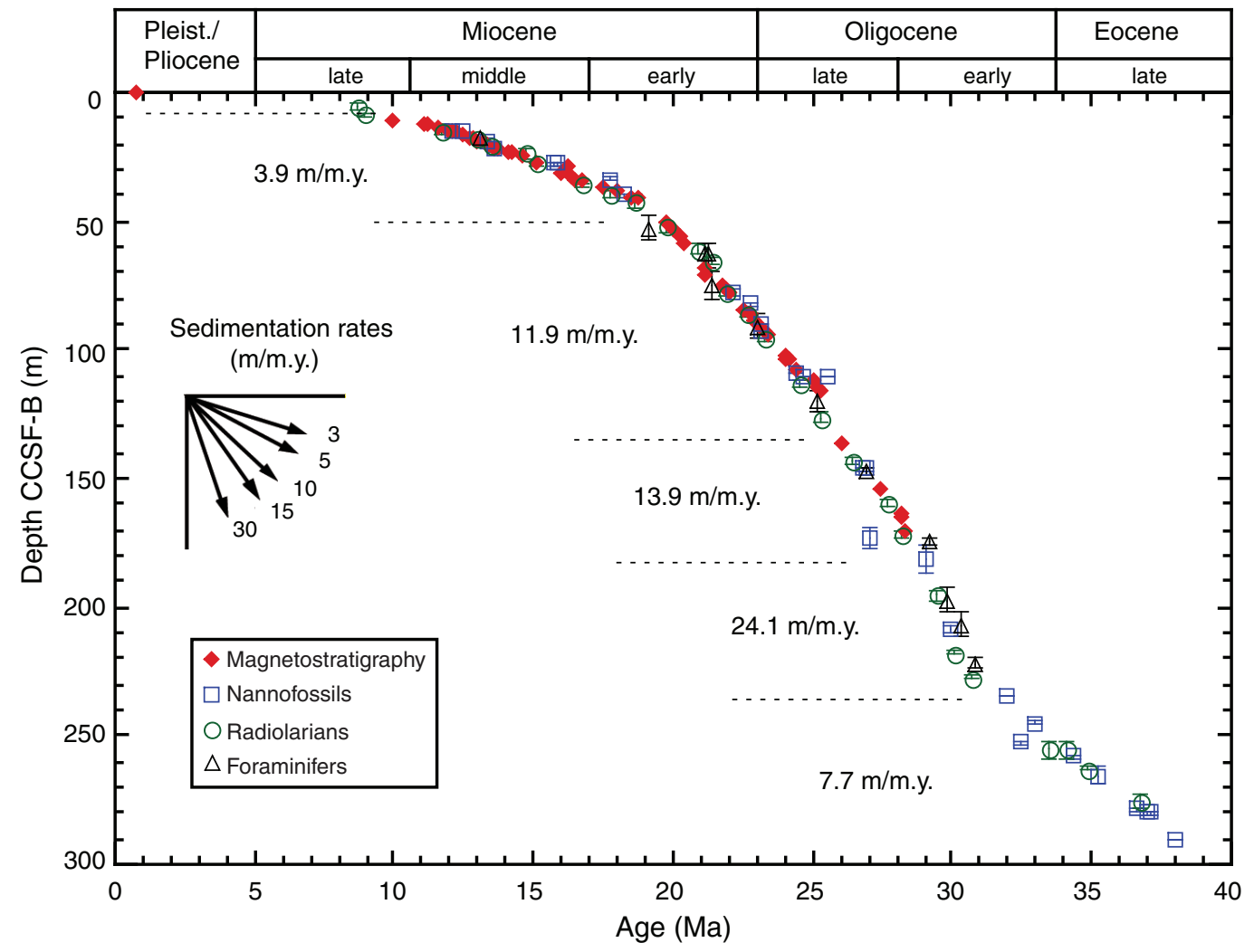


Figure F15. Stratigraphic distributions of abundance of Nuttallides umbonifer and Cibicidoides mundulus during the Oligocene. A. Site U1334. B. Site U1333. C. Site U1332.

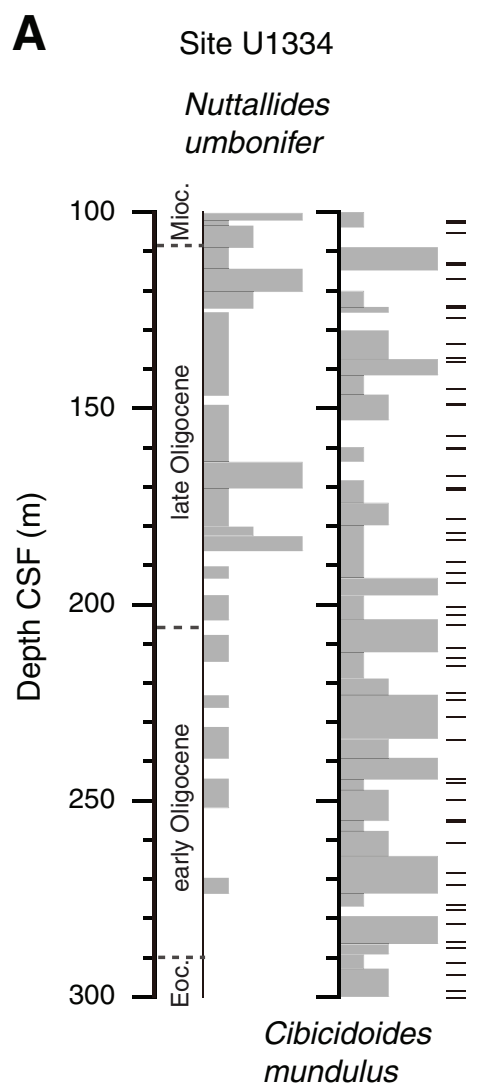

mundulus
B Site U1333

Nuttallides
umbonifer

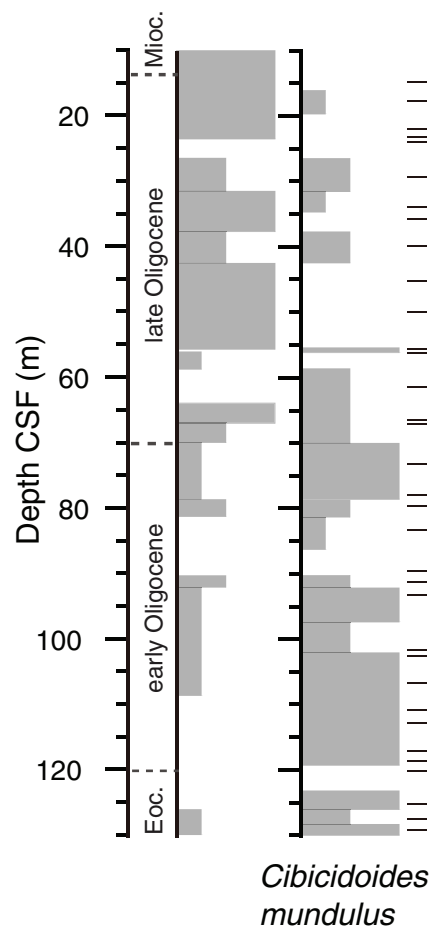

C Site U1332

Nuttallides umbonifer

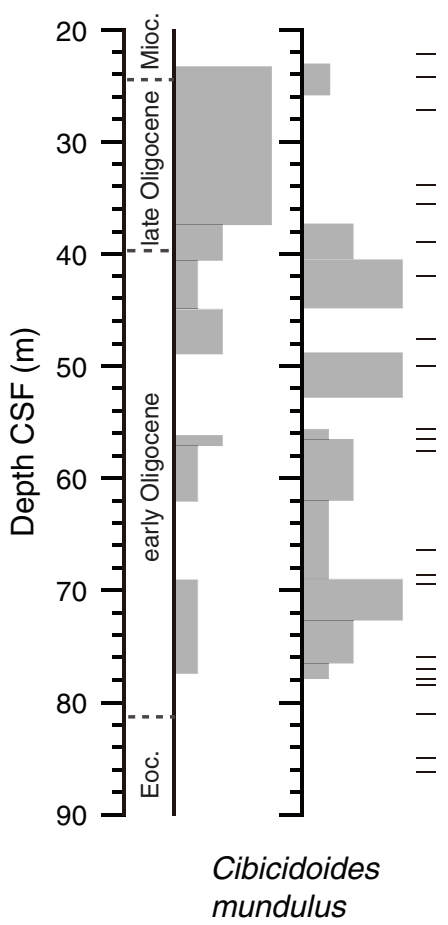

Abundant (>10\%) Few $(5 \%-10 \%)$

Rare (1\%-5\%)

Sample
horizon 
Figure F16. Summary of magnetic susceptibility and paleomagnetic results, Hole U1334A. Susceptibility measurements were on whole cores. ChRM directions for discrete samples were estimated using principal component analysis (PCA).

Hole U1334A

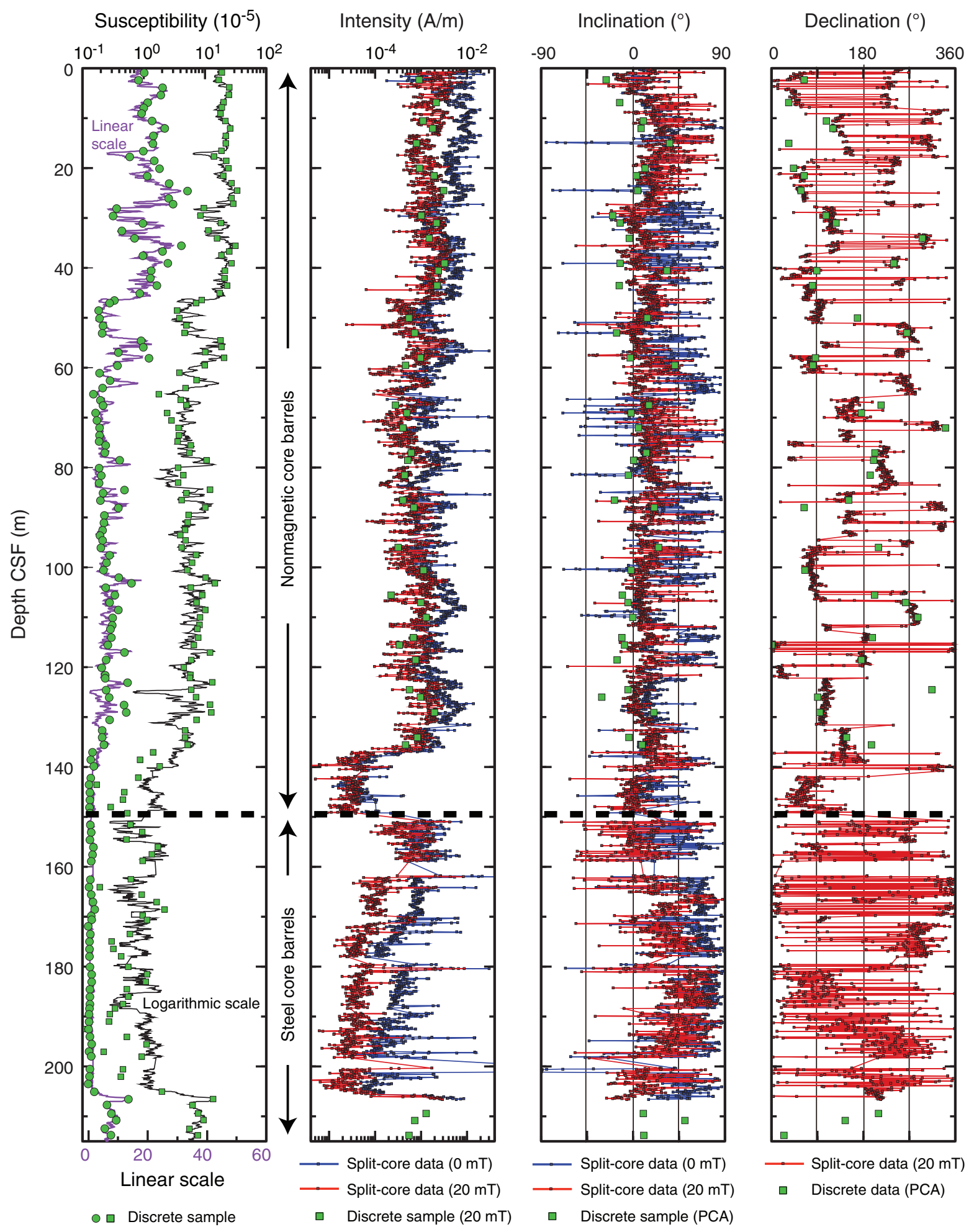


Figure F17. Summary of magnetic susceptibility and paleomagnetic results, Hole U1334B. Susceptibility measurements were on whole cores. ChRM directions for discrete samples were estimated using principal component analysis.

Hole U1334B

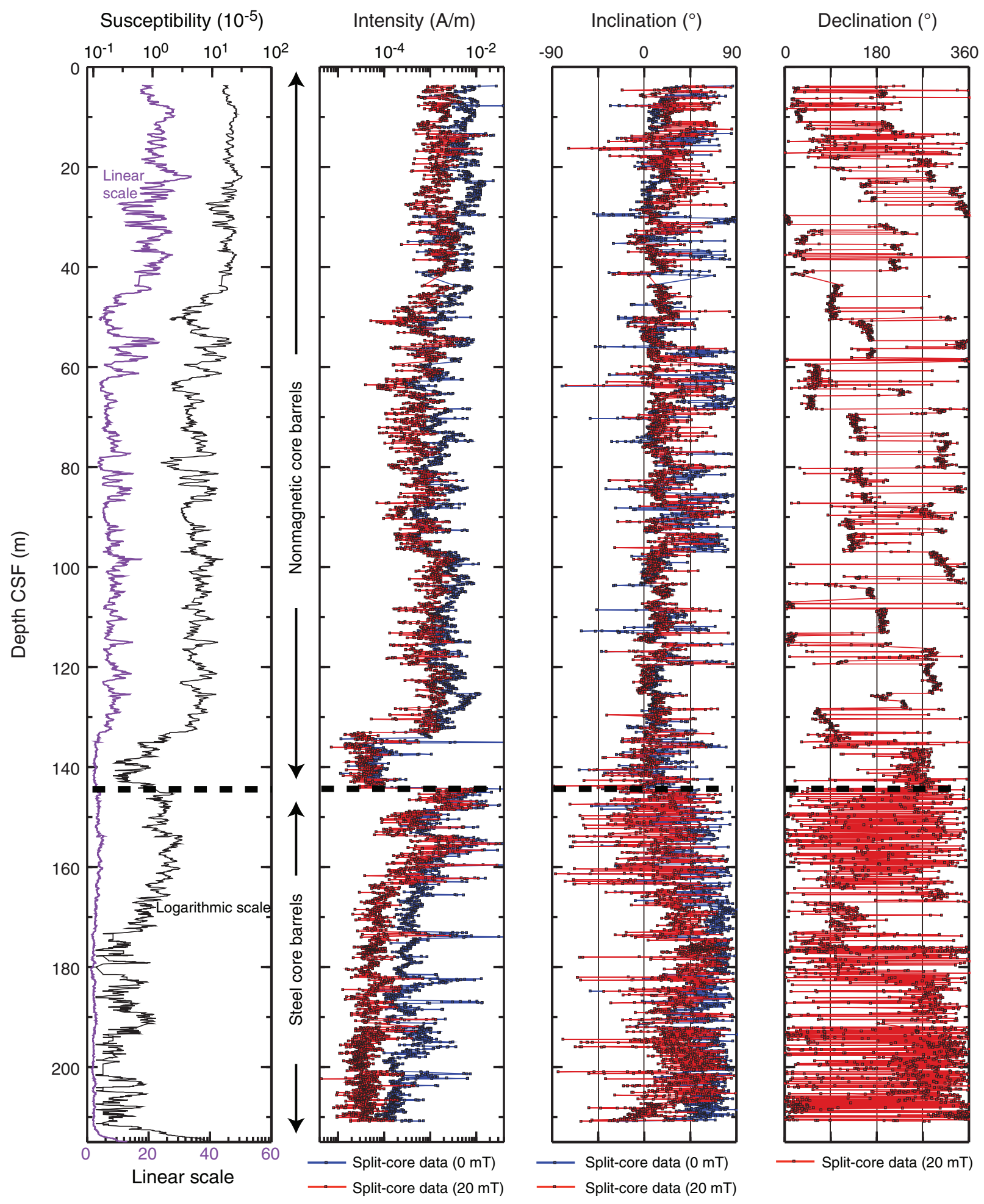


Figure F18. Summary of magnetic susceptibility and paleomagnetic results, Hole U1334C. Susceptibility measurements were on whole cores. ChRM directions for discrete samples were estimated using principal component analysis.

Hole U1334C

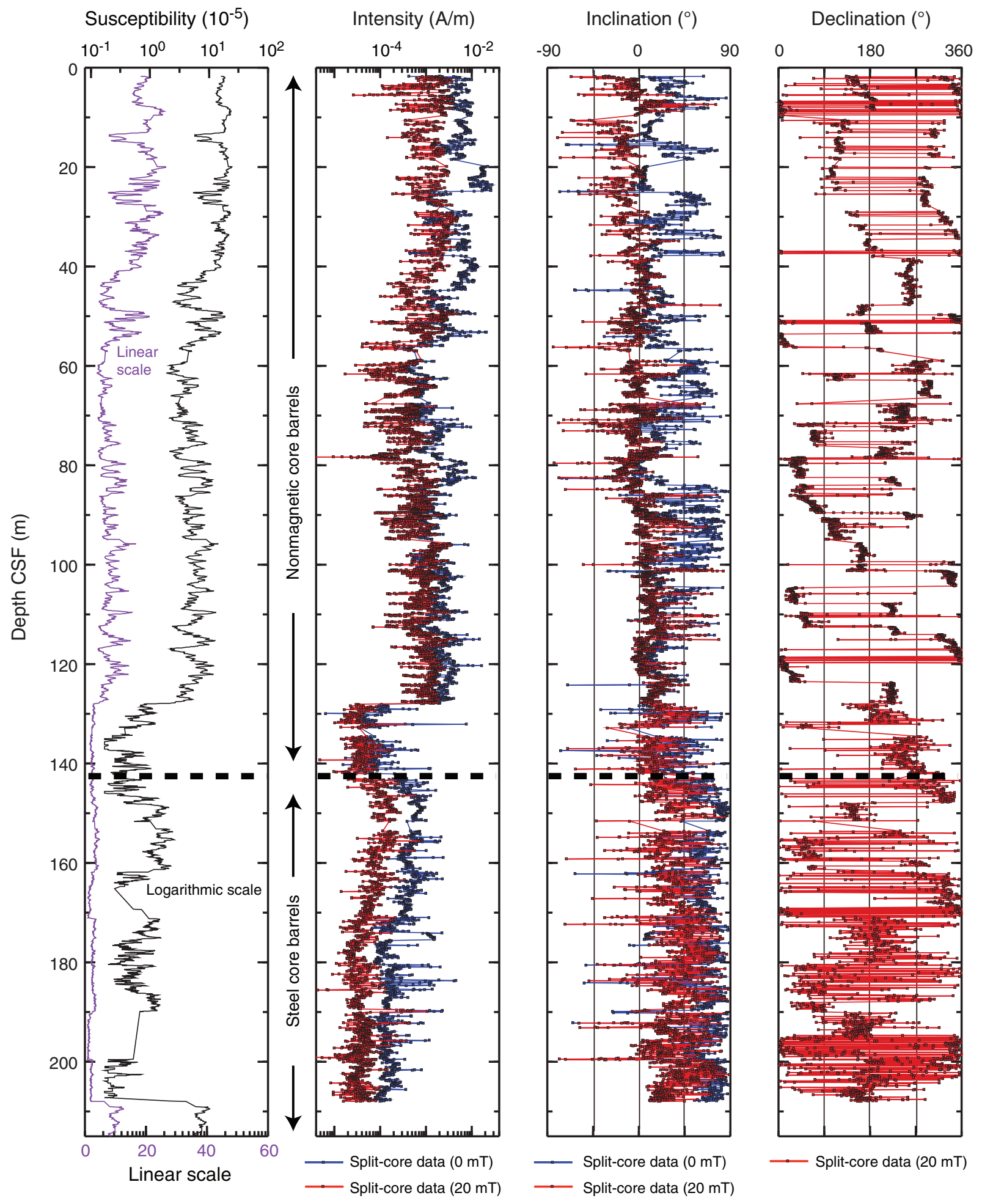


Figure F19. Latitude of the virtual geomagnetic pole (VGP), as determined from paleomagnetic directions, Hole U1334B. ${ }^{*}=$ locations of possible geomagnetic excursions. North latitudes = normal polarity, south latitudes = reversed polarity. Those intervals of indeterminate polarity are shaded gray. A. 0-30 m CSF. (Continued on next two pages.)

A

Hole U1334B

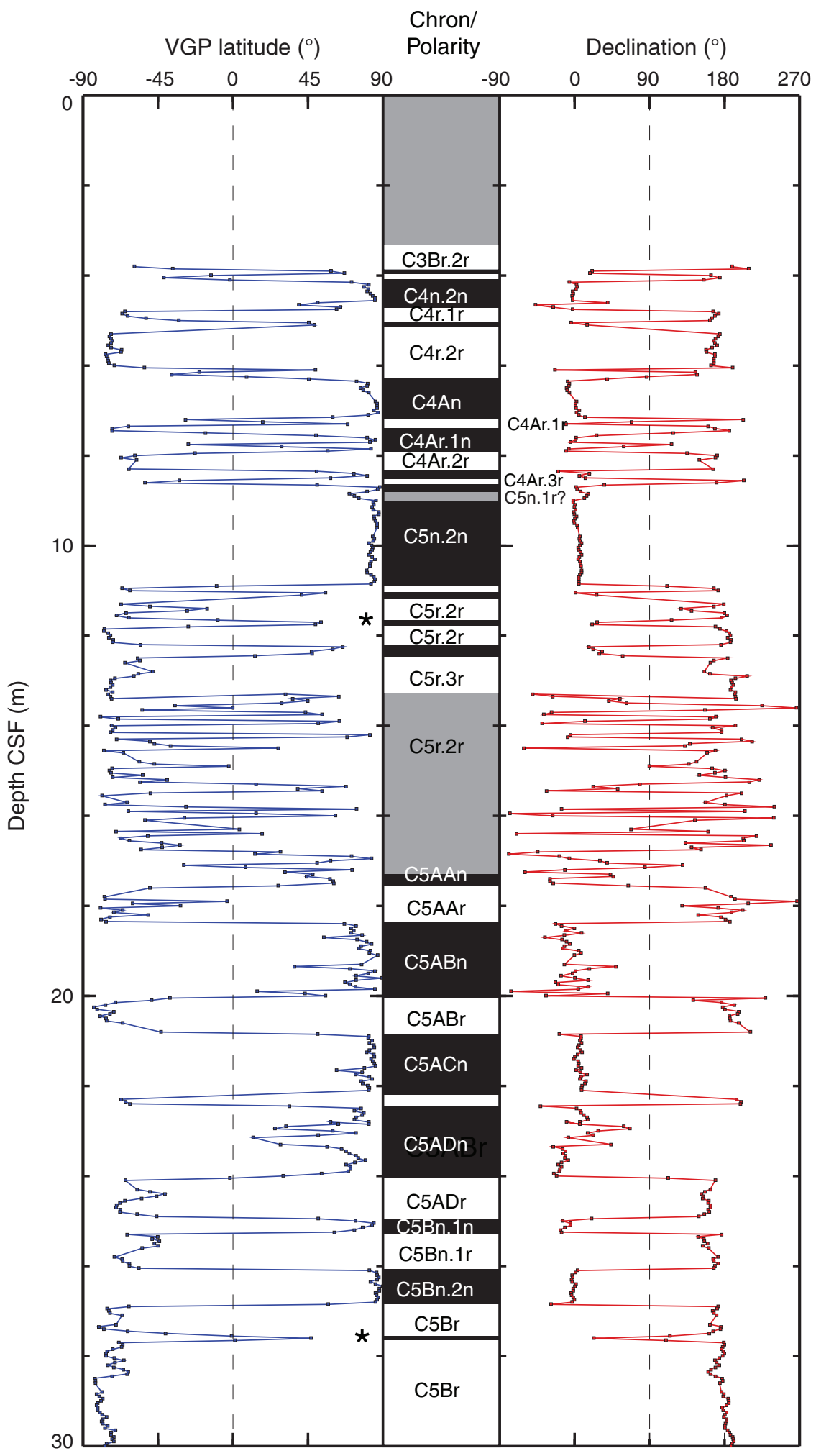


Figure F19 (continued). B. 25-105 m CSF. (Continued on next page.)

B

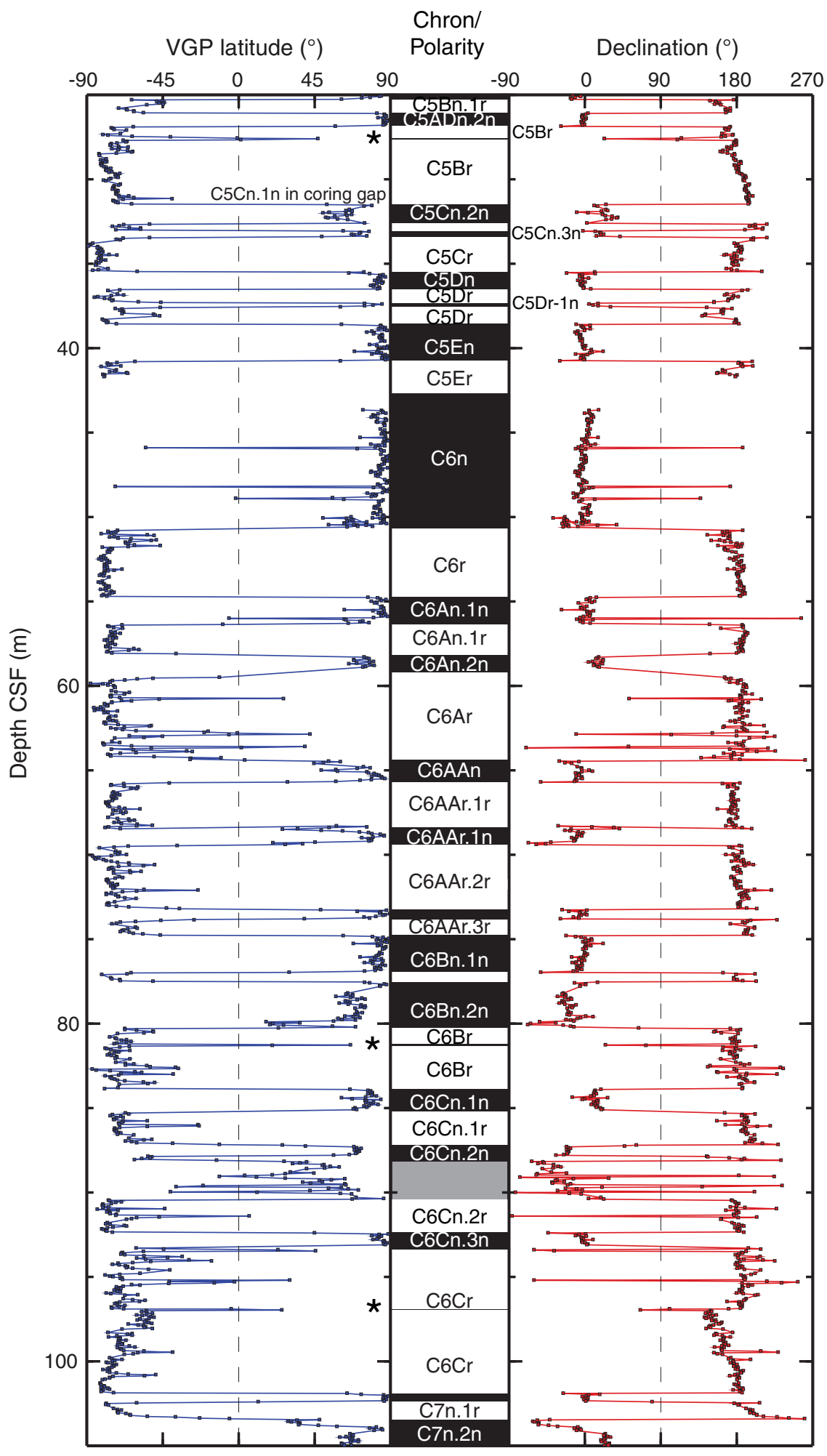


Figure F19 (continued). C. 100-215 m CSF.

C

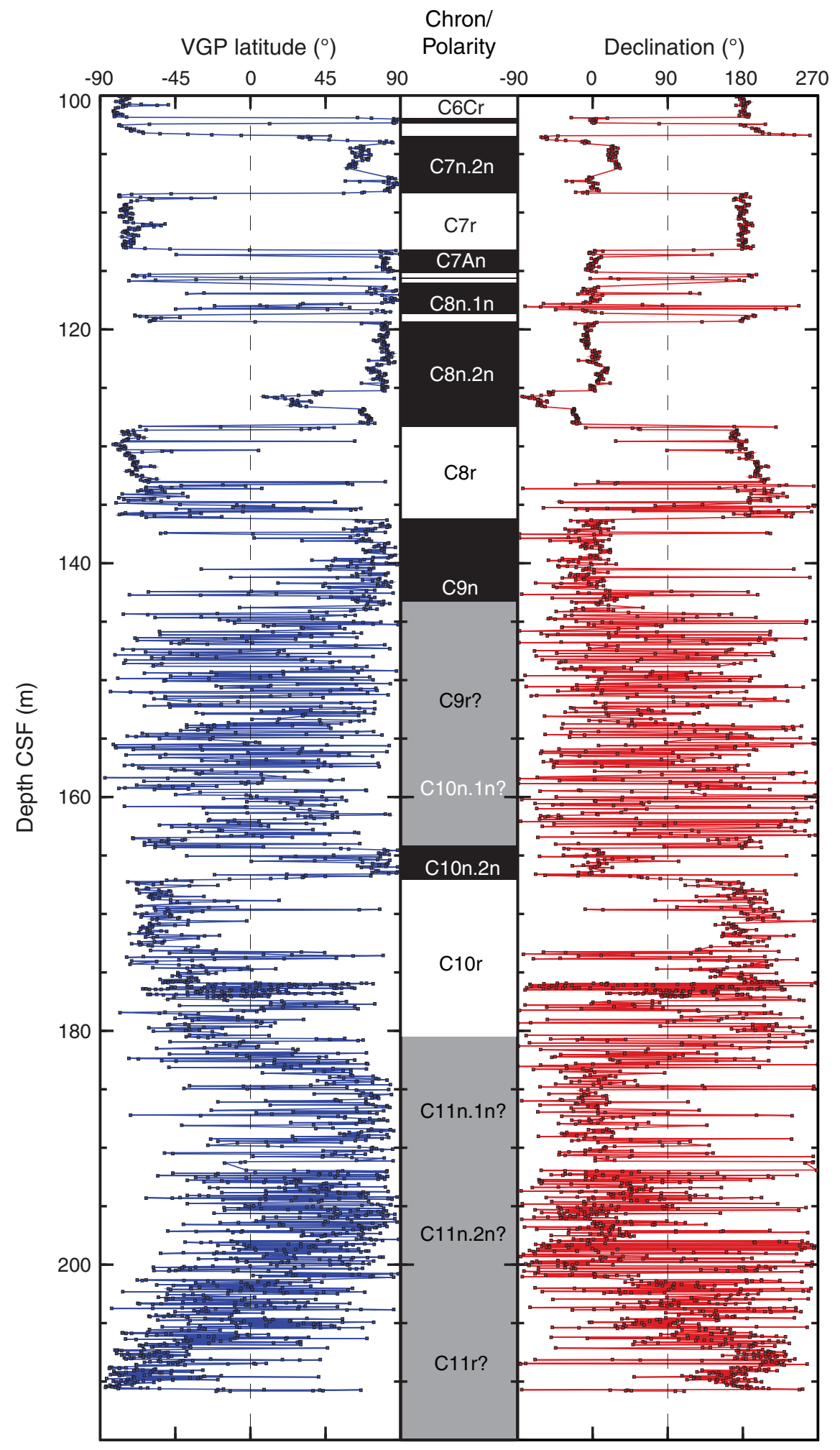


Figure F20. Alternating-field demagnetization (demag) results representative of some of the best samples from Site U1334. Top plot shows vector endpoints of paleomagnetic directions on vector demagnetization diagrams or modified Zijderveld plots (squares = inclinations, circles $=$ declinations), middle plot = intensity variation with progressive demagnetization, bottom plot = directions plotted on an equal-angle stereonet (Wulff projection). Data illustrate the removal of a steep drilling overprint by $\sim 10 \mathrm{mT}$, with the remaining magnetization providing a relatively well resolved characteristic remanent magnetization. A. Sample 320-U1334A-4H-5, 85 cm (34.05 m CSF). B. Sample 320-U1334A-5H-2, 85 cm (39.05 m CSF). NRM = natural remanent magnetization.

A Sample $320-\mathrm{U} 1334 \mathrm{~A}-4 \mathrm{H}-5,85 \mathrm{~cm}$ Depth: 34.05 m CSF

Maximum intensity $=3.99 \times 10^{-3} \mathrm{~A} / \mathrm{m}$
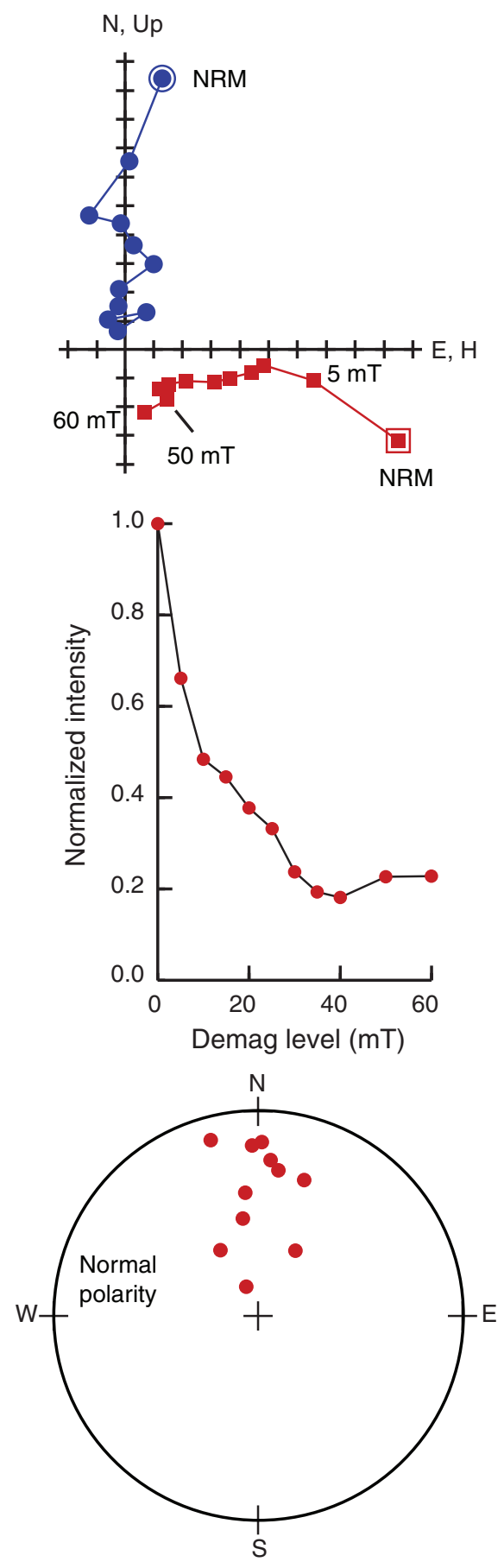

B Sample 320-U1334A-5H-2, $85 \mathrm{~cm}$ Depth: 39.05 m CSF

Maximum intensity $=3.743 \times 10^{-3} \mathrm{~A} / \mathrm{m}$

$\mathrm{N}$, Up
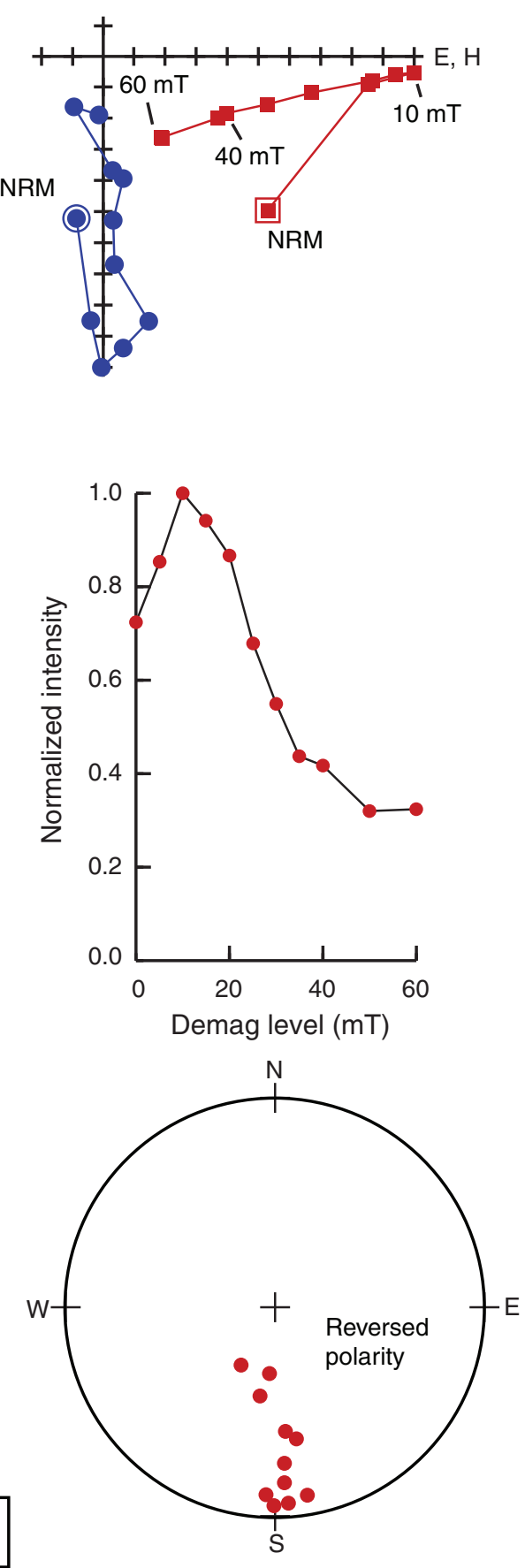
Figure F21. Latitude of the virtual geomagnetic pole (VGP), Hole U1334A. * = locations of possible geomagnetic excursions. North latitudes $=$ normal polarity, south latitudes $=$ reversed polarity. Those intervals of indeterminate polarity are shaded gray. A. 0-30 m CSF. (Continued on next two pages.)

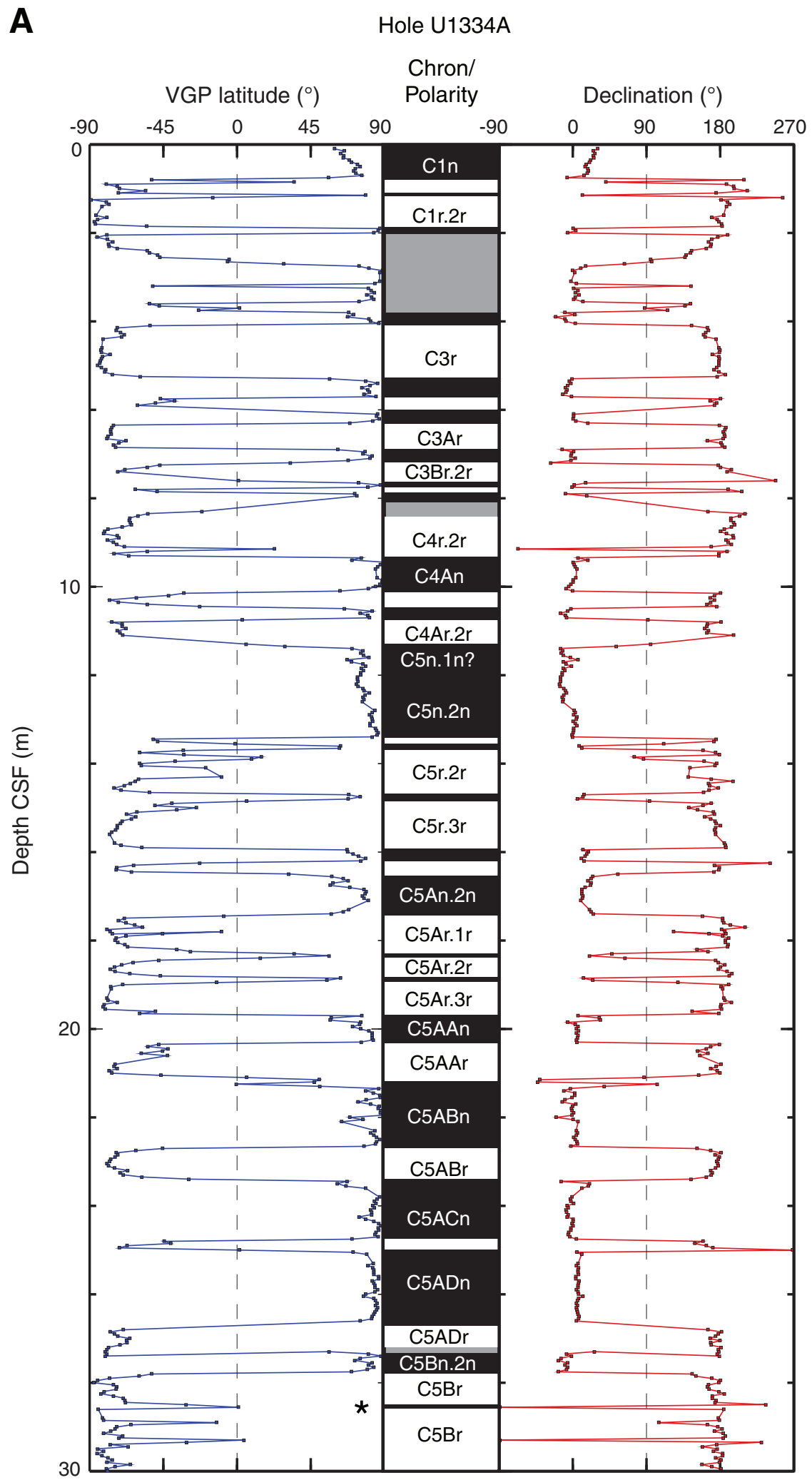


Figure F21 (continued). B. 25-105 m CSF. (Continued on next page.)

B

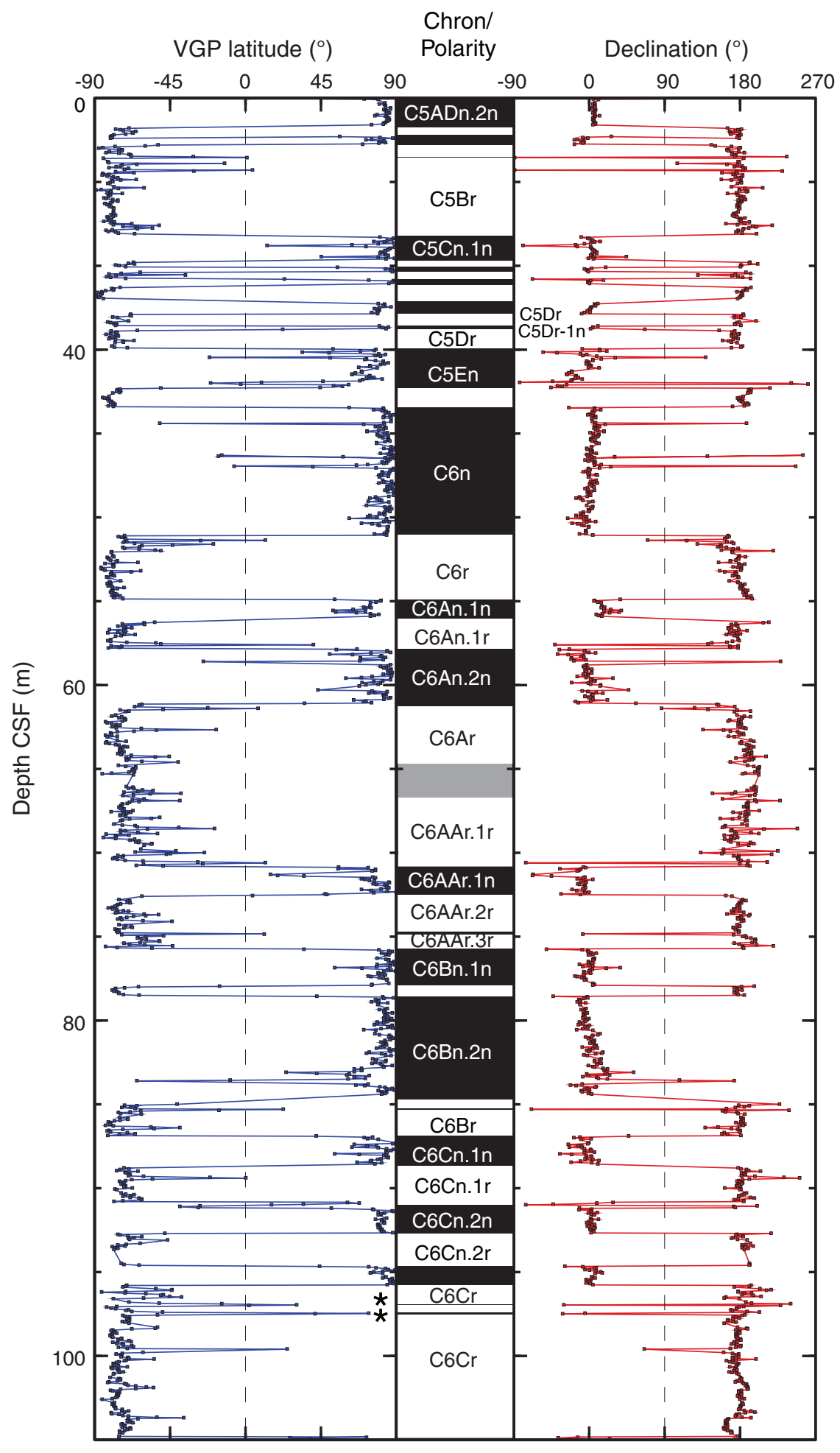


Figure F21 (continued). C. 100-215 m CSF.

C

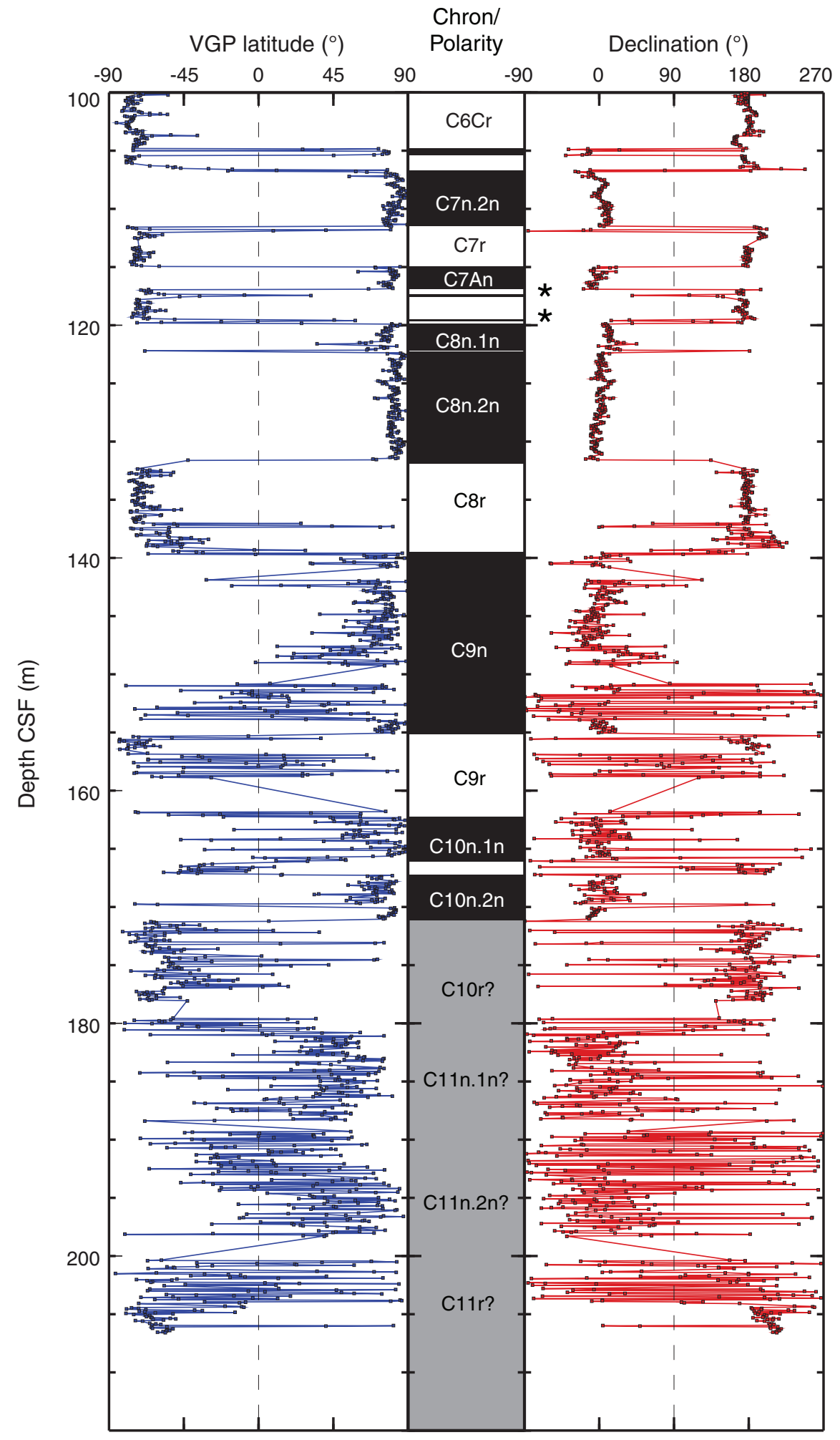


Figure F22. Latitude of the virtual geomagnetic pole (VGP), as determined from paleomagnetic directions, Hole U1334C. ${ }^{*}=$ locations of possible geomagnetic excursions. North latitudes = normal polarity, south latitudes = reversed polarity. Those intervals of indeterminate polarity are shaded gray. A. 0-30 m CSF. (Continued on next two pages.)

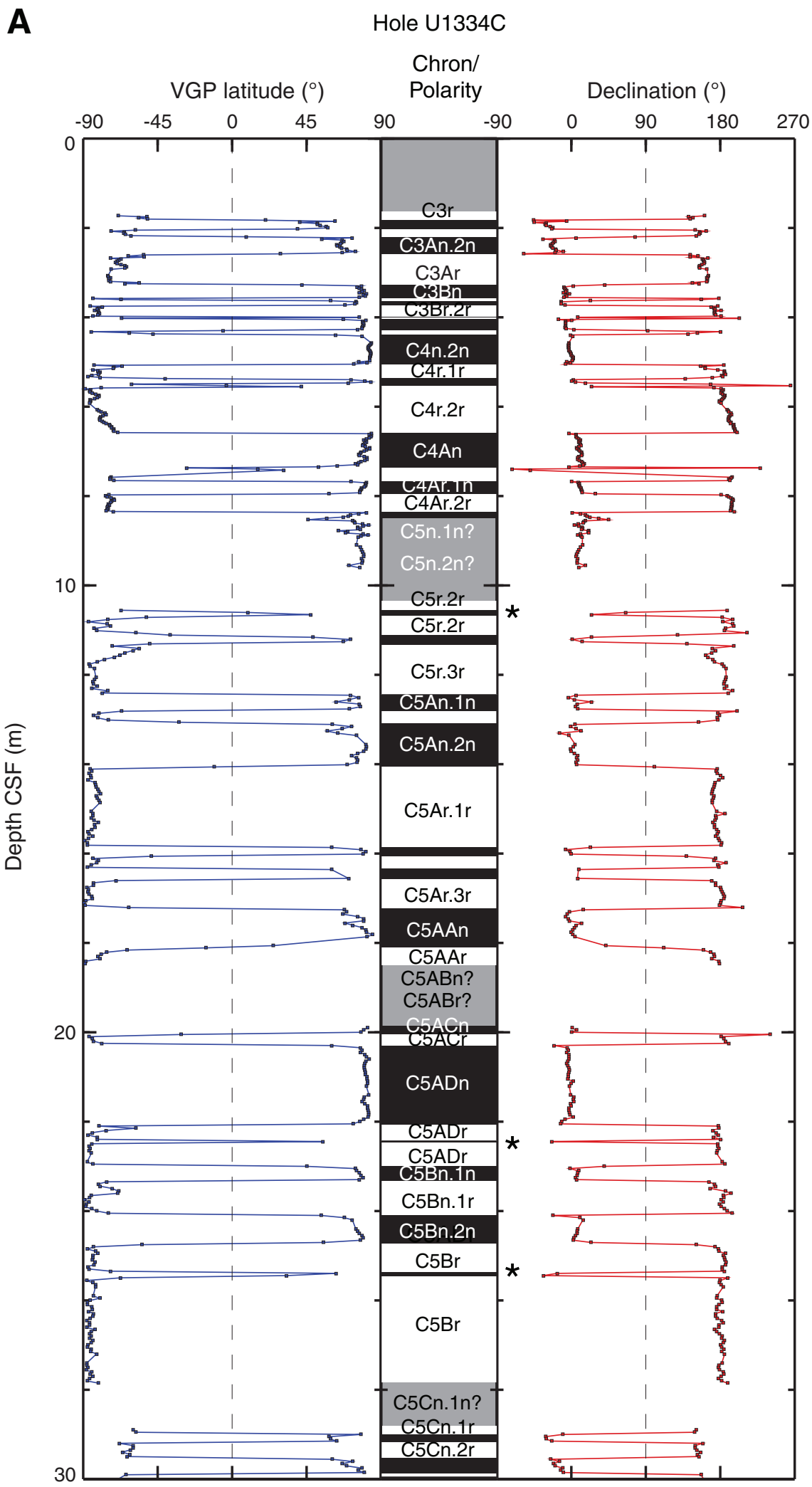


Figure F22 (continued). B. 25-105 m CSF. (Continued on next page.)

B

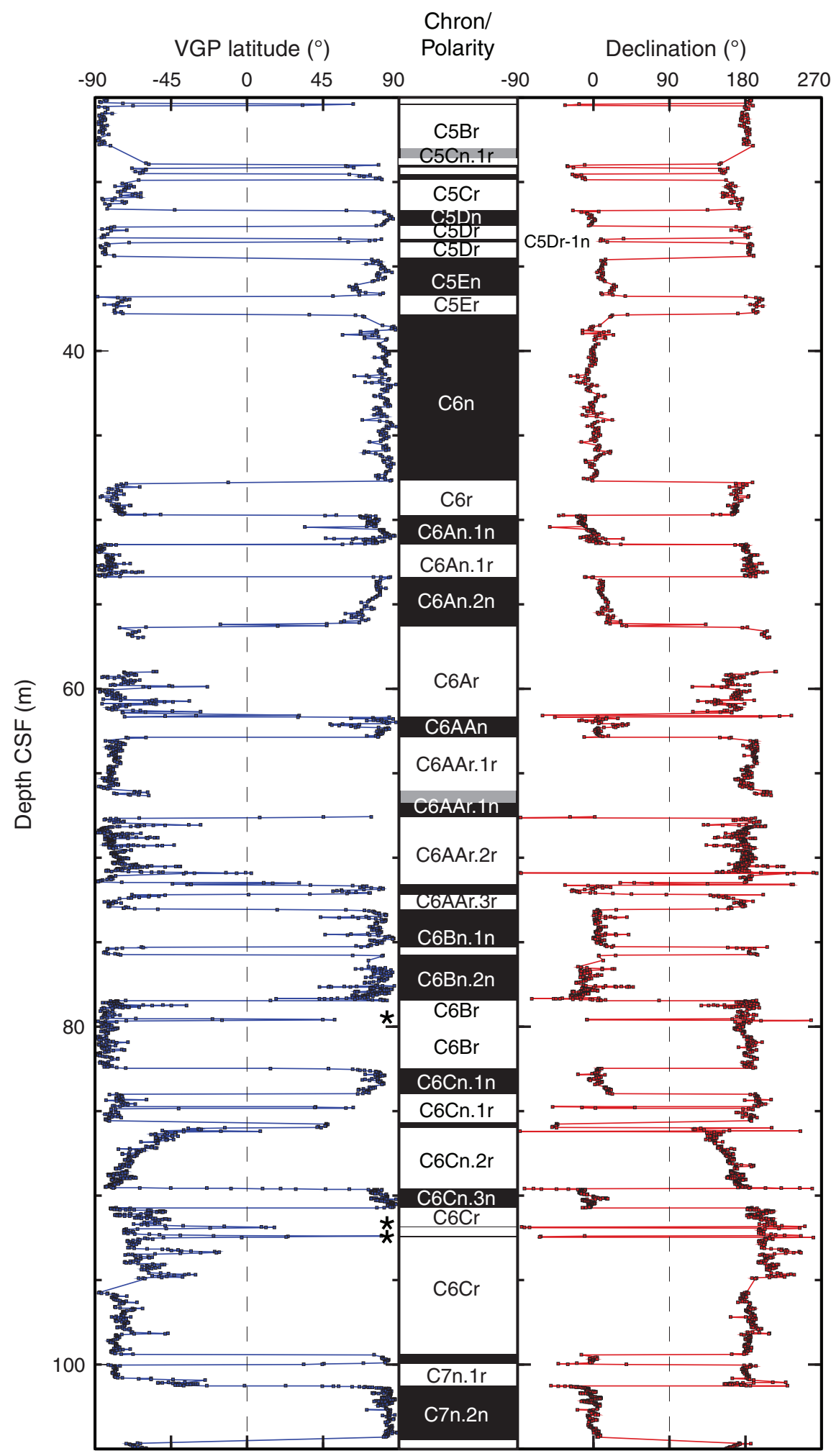


Figure F22 (continued). C. 100-215 m CSF.

C

Hole U1334C

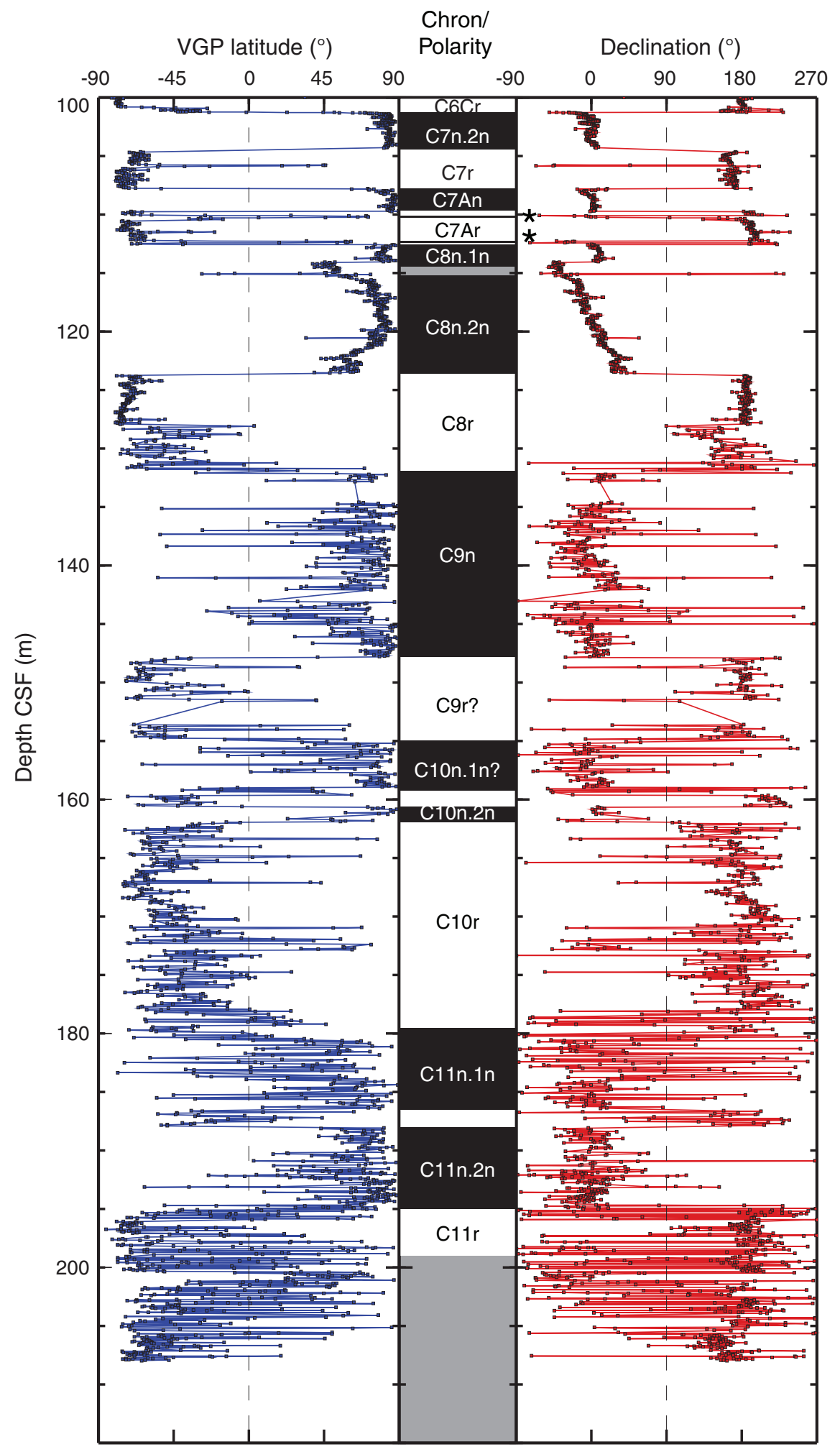


Figure F23. Interstitial water chemistry, Hole U1334A. Values below the detection limit (see Table T23) are plotted as zero. (See "Lithostratigraphy" for information on unit boundaries.)
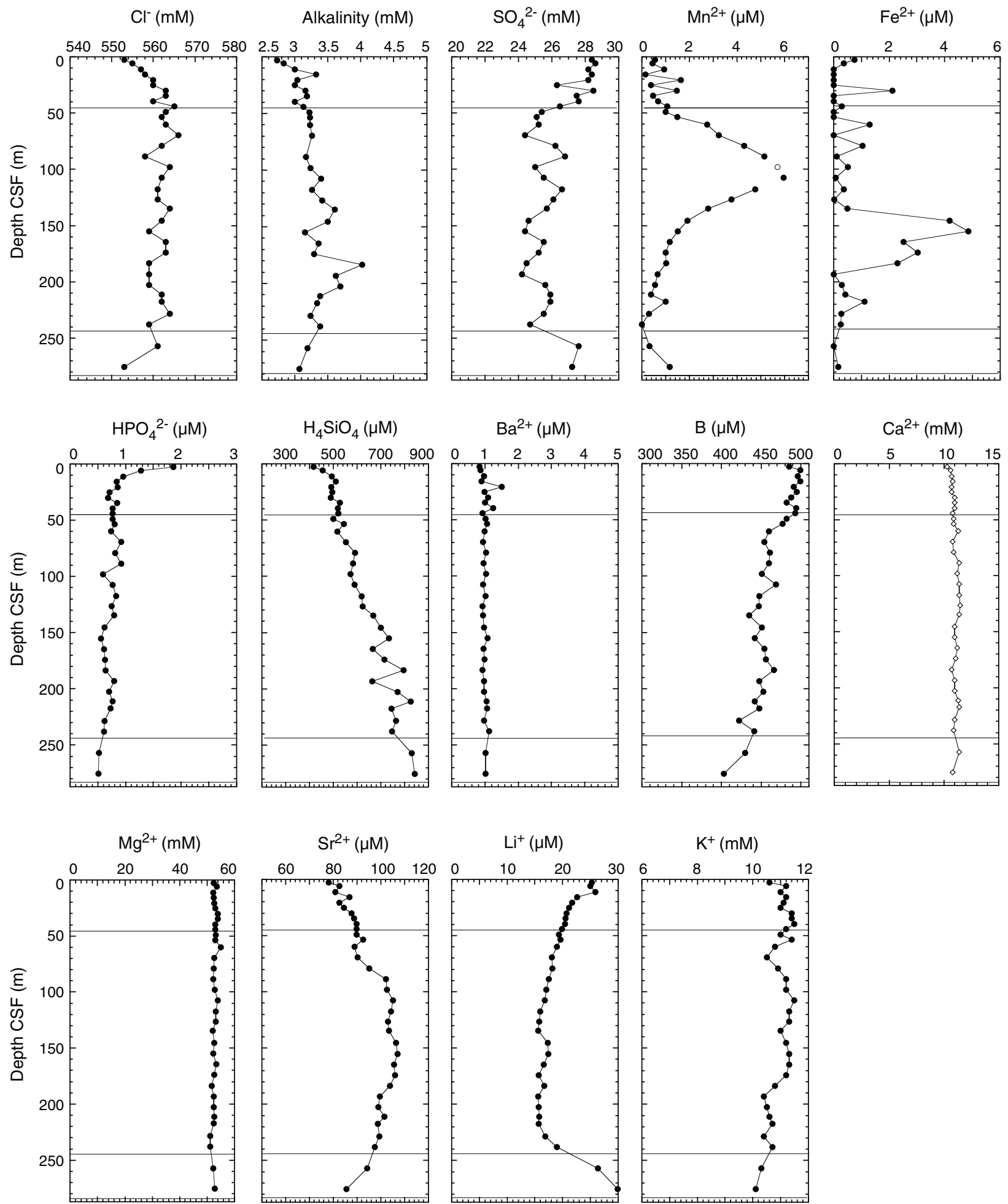
Figure F24. Interstitial water chemistry from Rhizon samples, Holes U1334B and U1334C. Values below the detection limit (see Table T24) are plotted as zero.

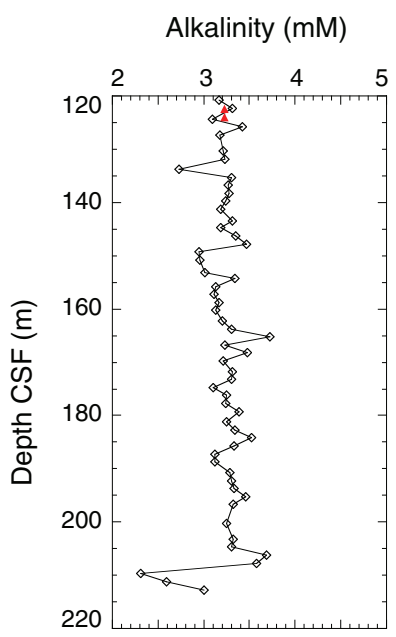

Sulfate (mM)

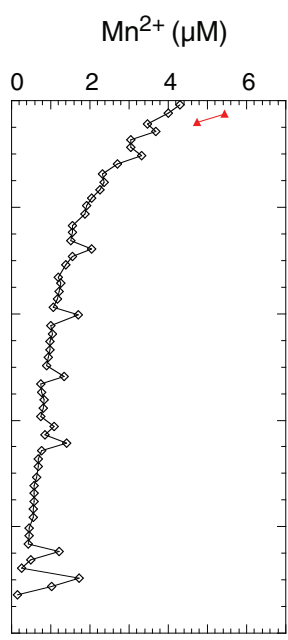

$\mathrm{Fe}^{2+}(\mu \mathrm{M})$
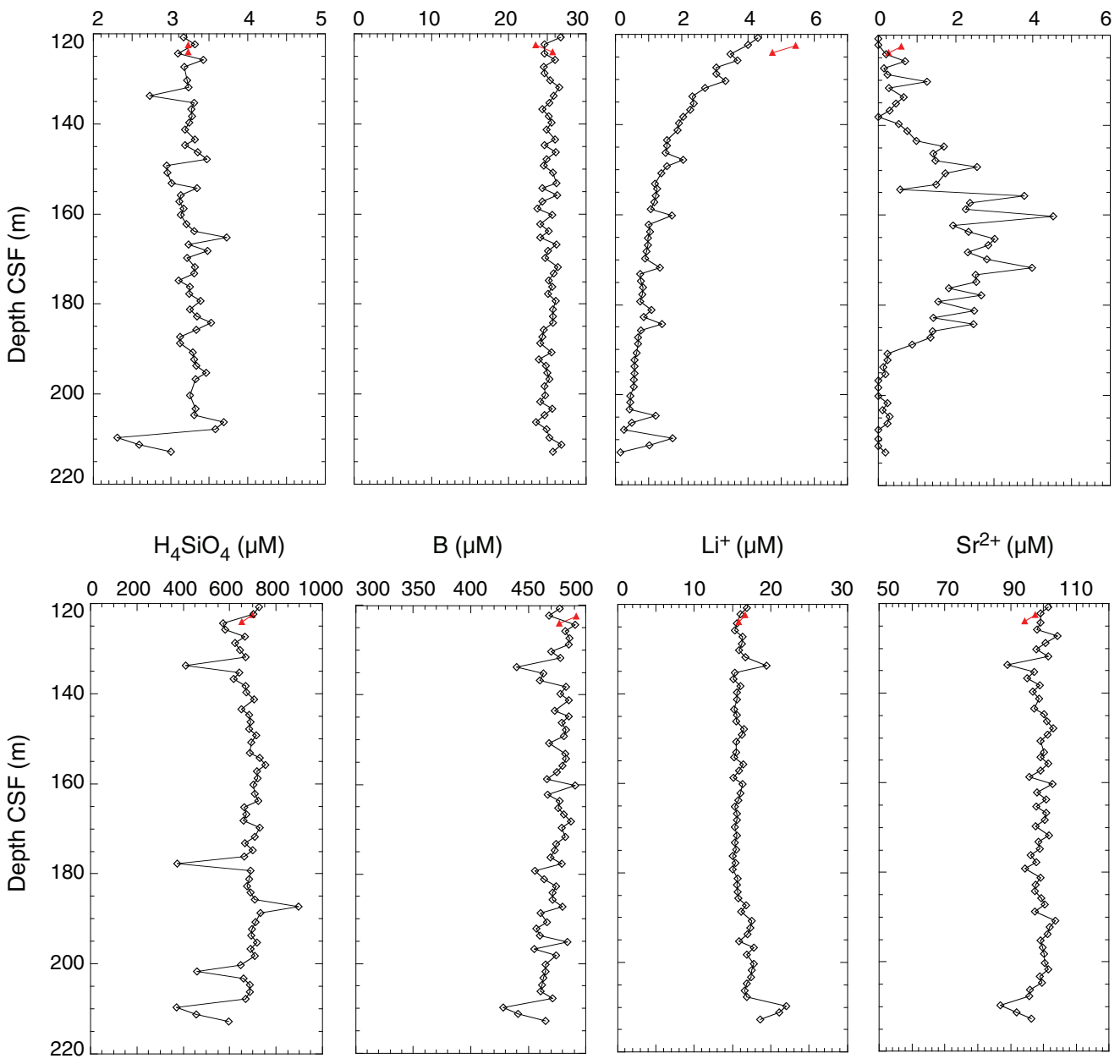

$\mathrm{Li}^{+}(\mu \mathrm{M})$

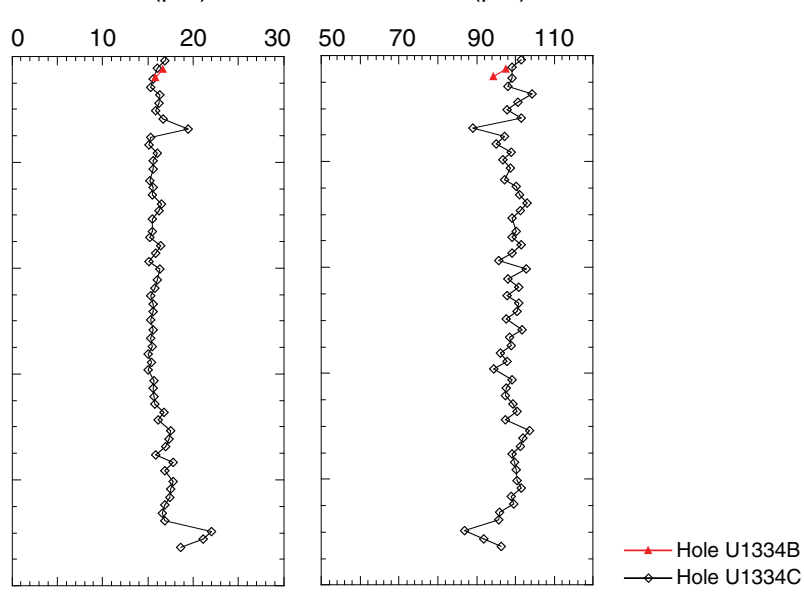

— Hole U1334B 
Figure F25. Interstitial water chemistry, Site U1334, comparing Rhizon and squeezed samples. Values below the detection limit (Tables T23, T24) are plotted as zero. Hole U1334C samples are Rhizon samples; other samples are whole-round samples. $\mathrm{DD}=$ drilling disturbance, $\mathrm{XCB}=$ extended core barrel.

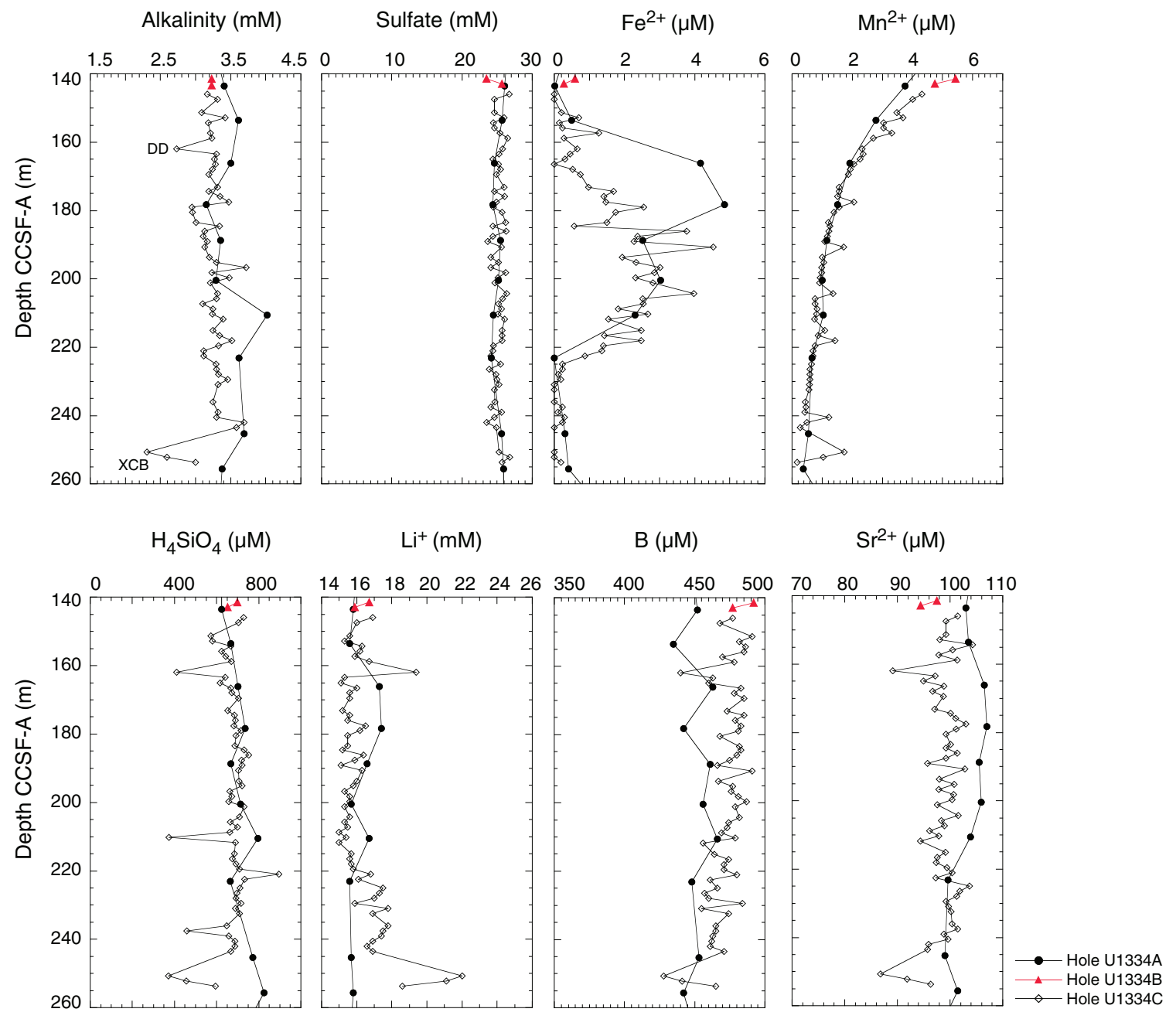


Figure F26. Whole-Round Multisensor Logger (WRMSL) and natural gamma radiation (NGR) data, Holes U1334A-U1334C. Hole U1334B and U1334C data are plotted using offsets $\left(0.5\right.$ and $1.0 \mathrm{~g} / \mathrm{cm}^{3}$ for gamma ray attenuation [GRA] bulk density; $10 \times 10^{-5}$ and $20 \times 10^{-5}$ SI for magnetic susceptibility; 100 and $200 \mathrm{~m} / \mathrm{s}$ for $P$ wave velocity; 10 and 20 cps for NGR).

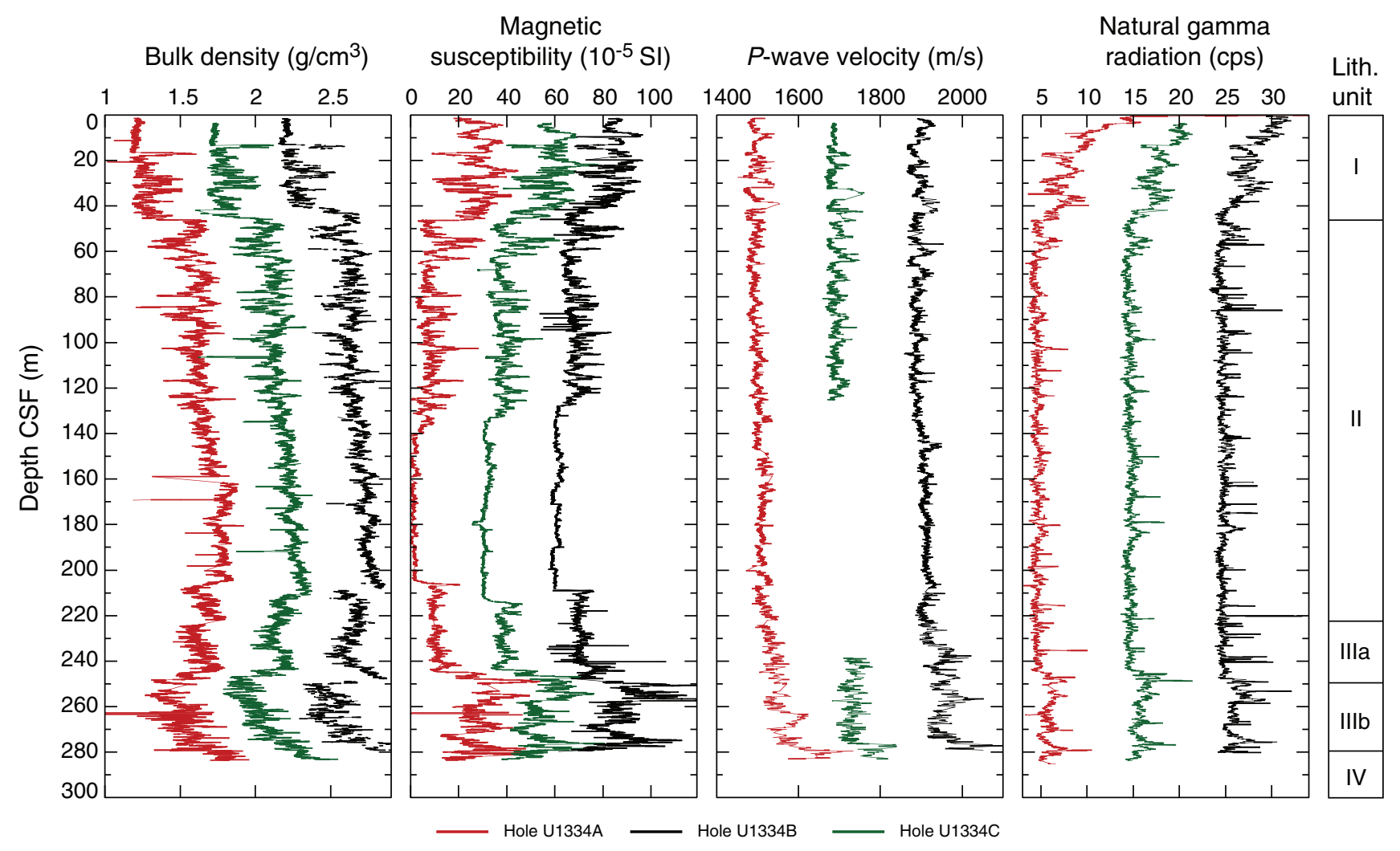


Figure F27. Moisture and density measurements, Hole U1334A. A. Porosity and water content. B. MAD and GRA bulk density. C. Grain density.

A

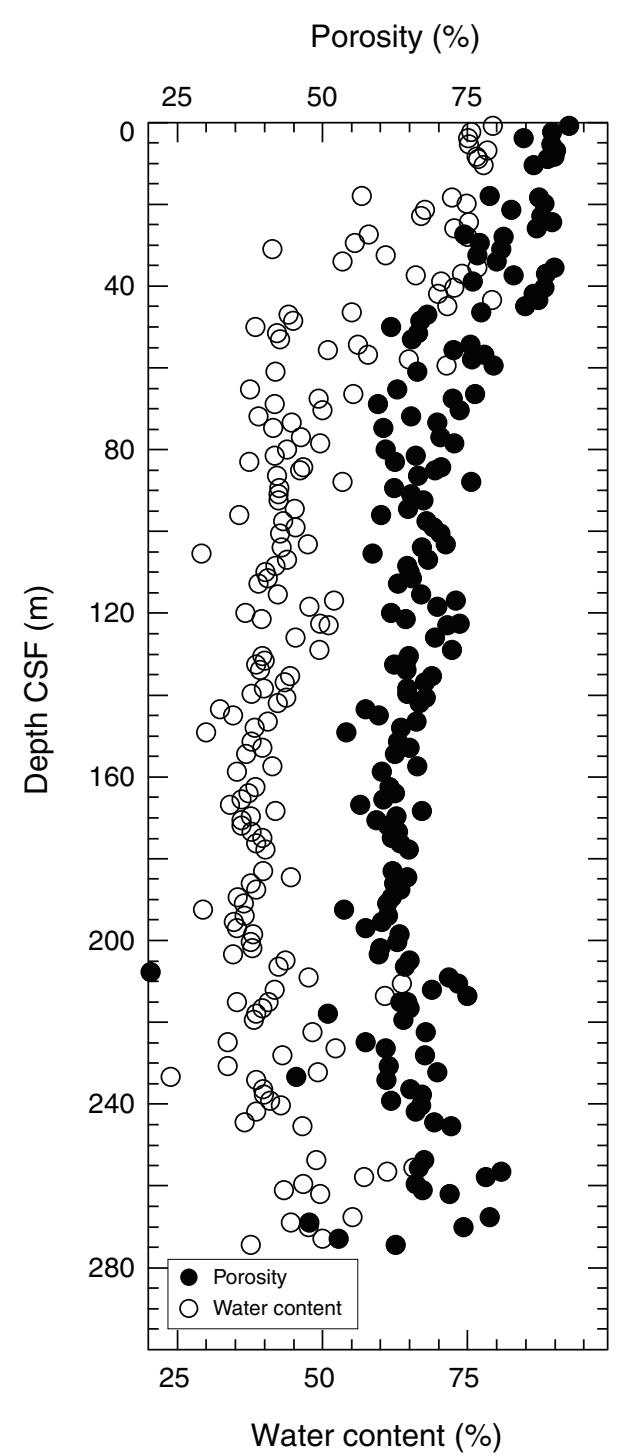

B

Bulk density $\left(\mathrm{g} / \mathrm{cm}^{3}\right)$

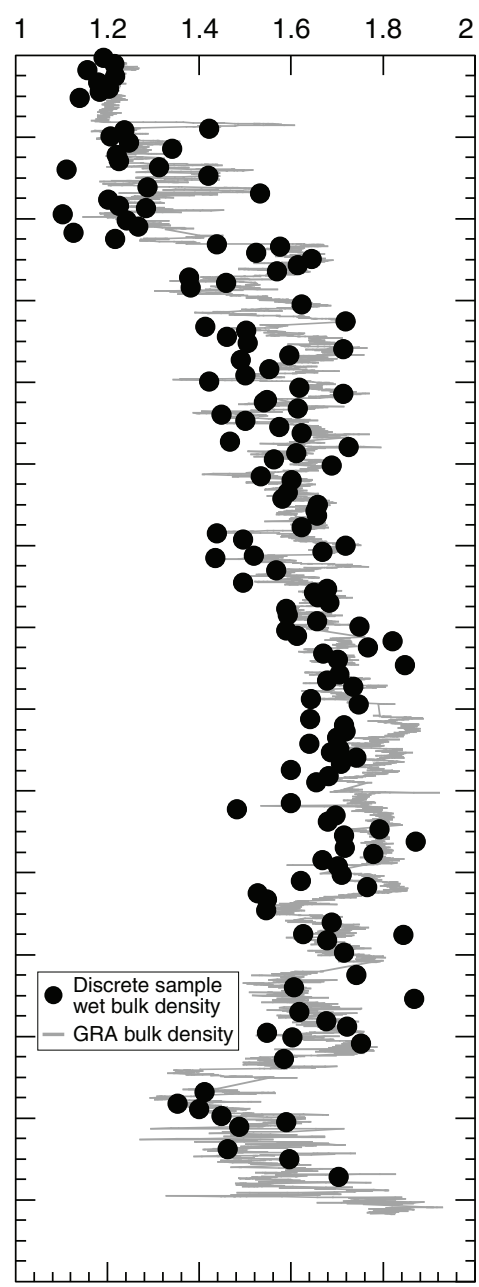

C

Grain density $\left(\mathrm{g} / \mathrm{cm}^{3}\right)$

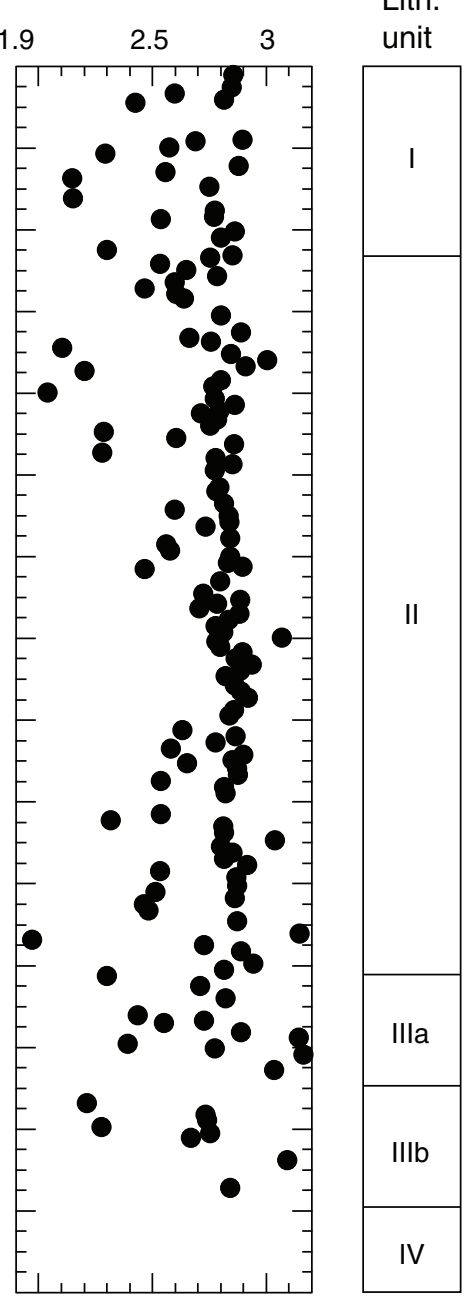

Lith. 
Figure F28. Moisture and density (MAD) analysis of discrete samples, Hole U1334A. Gamma ray attenuation (GRA) density interpolated with a $20 \mathrm{~cm}$ wide Gaussian window.
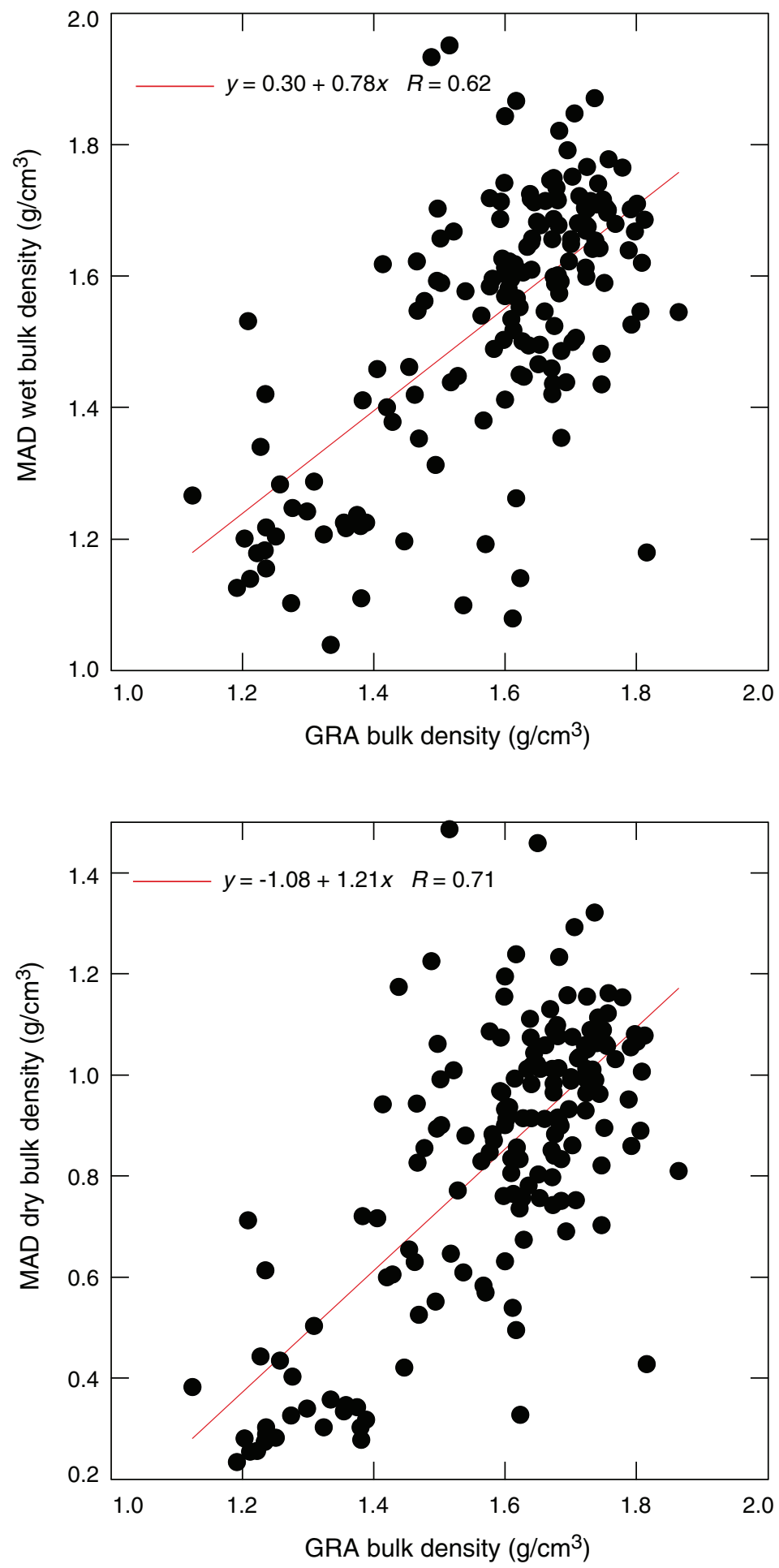
Figure F29. Compressional wave velocity from the $P$-wave logger (PWL) and discrete velocity measurements on split core from Hole U1334A, using the contact probe for $x$-axis measurements and insertion probes for $y$ and $z$-axis measurements. (see "Compressional wave velocity" for note on postcruise velocity correction.)

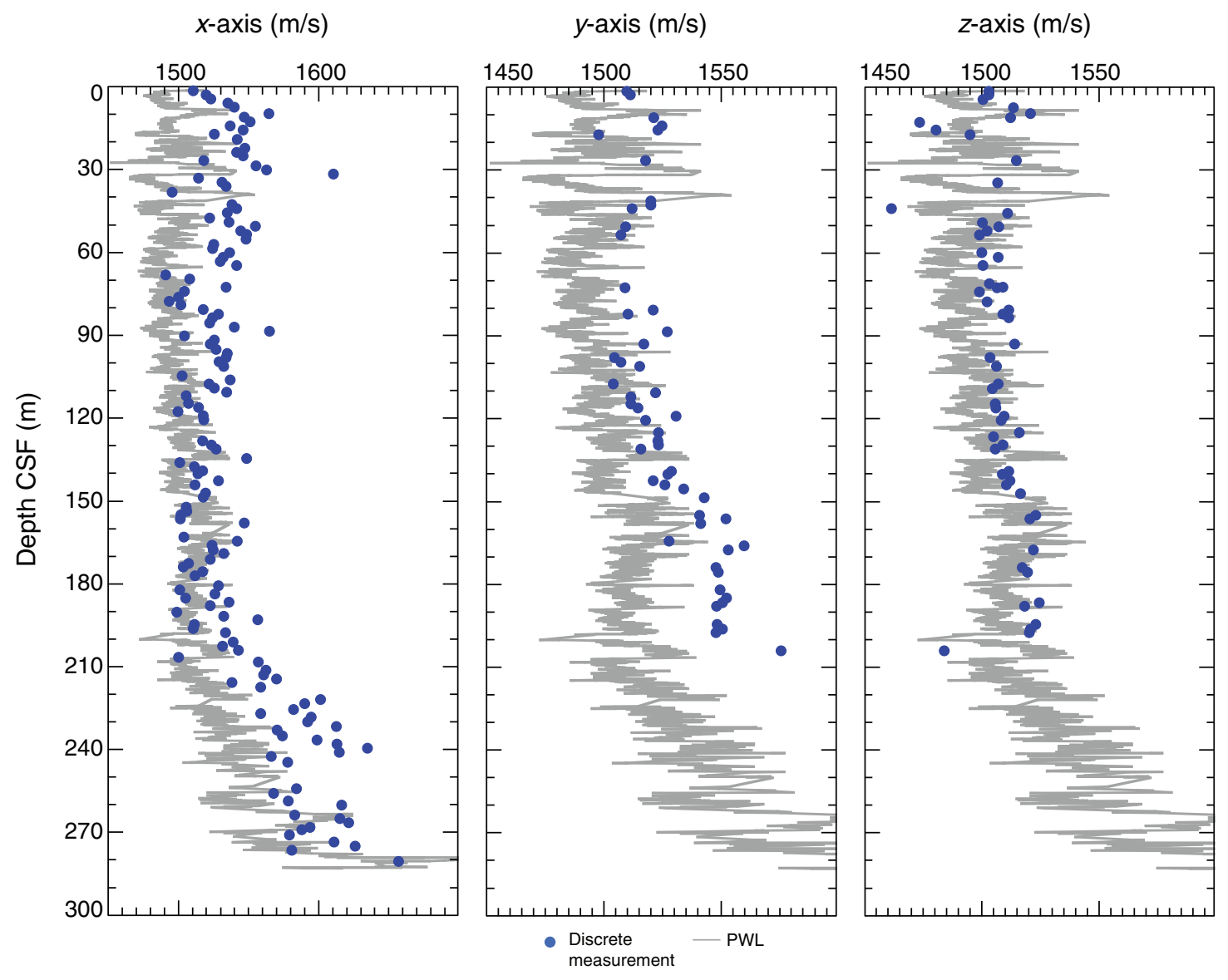


Figure F30. Porosity and thermal conductivity measurements, Hole U1334A.

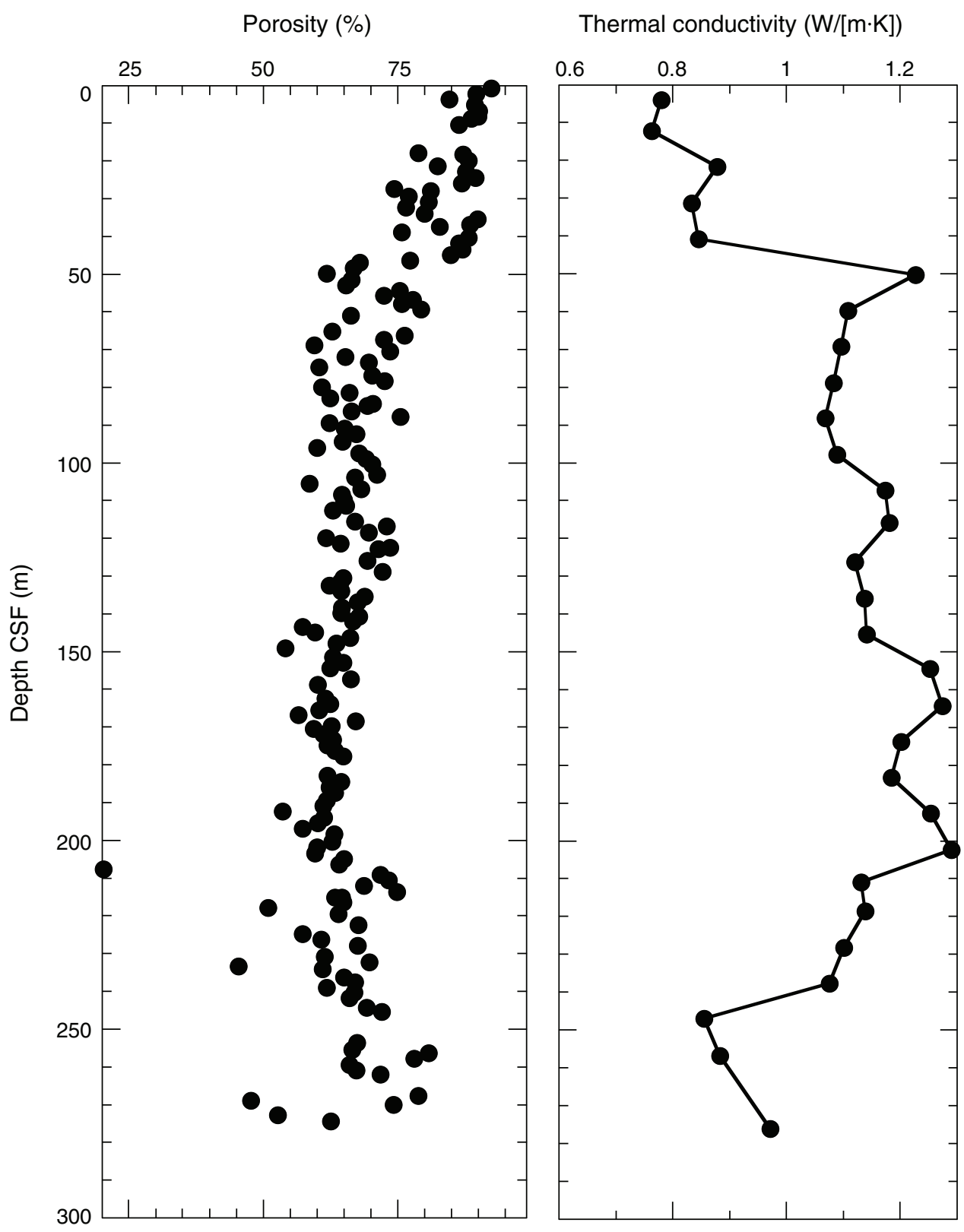


Figure F31. Thermal conductivity vs. porosity, from moisture and density analysis of discrete samples.

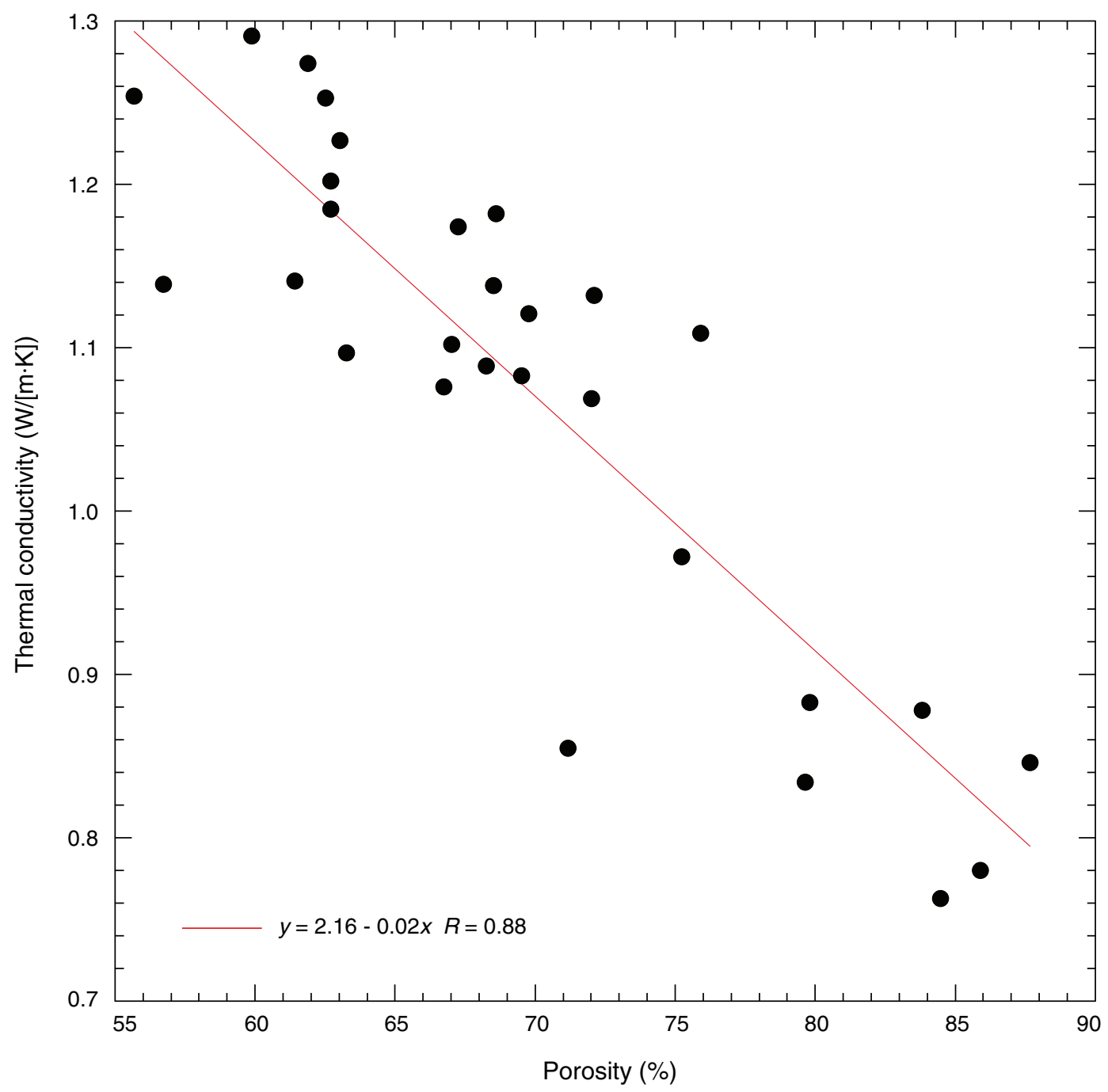


Figure F32. Reflectance spectrophotometer (RSC) data, Holes U1334A-U1334C. RSC for Holes U1334B and U1334C have been offset ( 20 and 40 for $\mathrm{L}^{*} ; 4$ and 5 for $\mathrm{a}^{*} ; 8$ and 10 for $\mathrm{b}^{*}$ ) for core to core comparison. $\mathrm{L}^{*}, \mathrm{a}^{*}$, $\mathrm{b}^{*}=$ reflectance value of sediment as defined in the LAB color model.

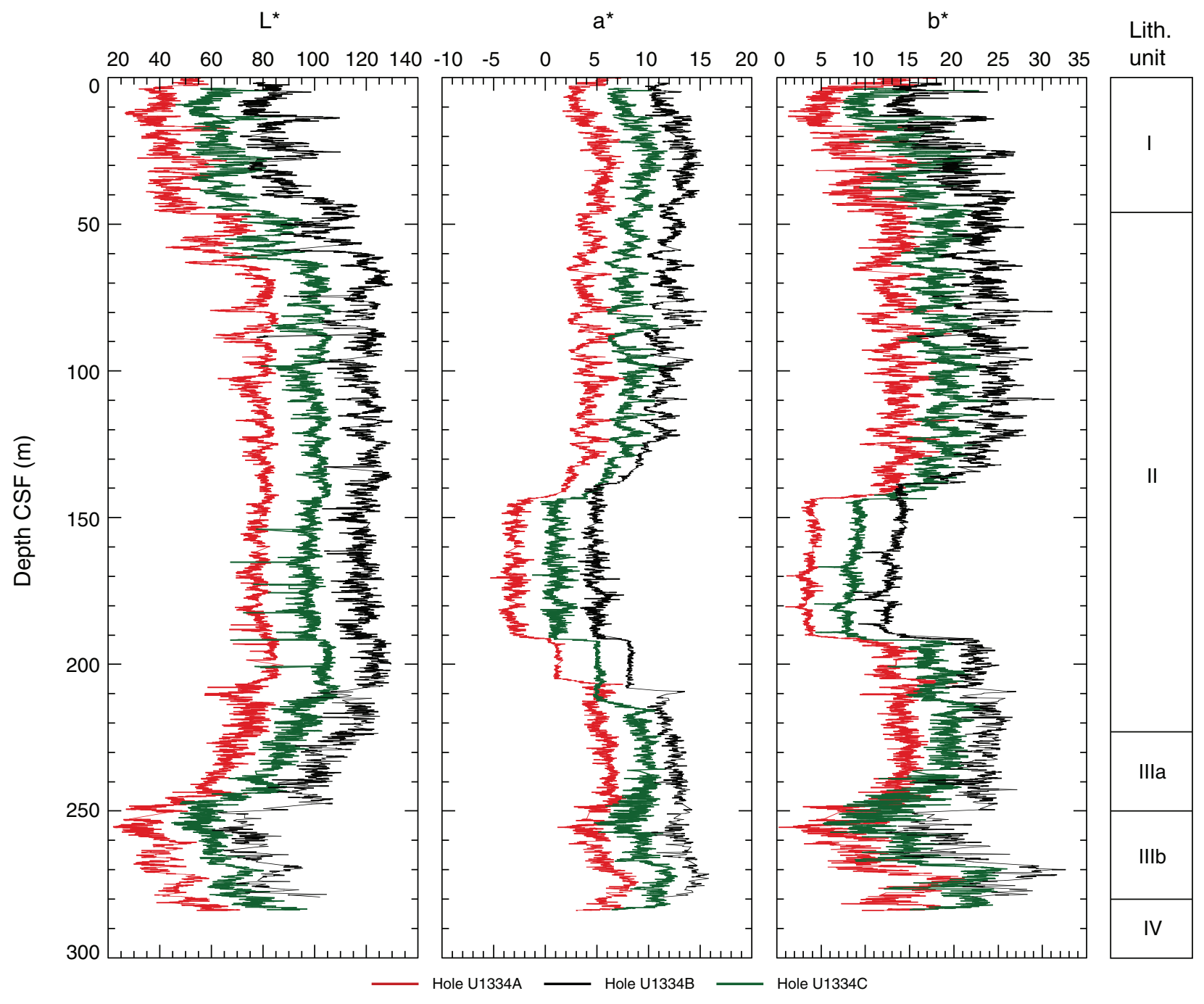


Figure F33. Magnetic susceptibility data, Site U1334. Top panel = spliced section with core breaks (triangles) and hole designations, bottom panel = Holes U1334A (red), U1334B (blue), and U1334C (green), offset from each other by a constant $\left(200 \times 10^{-6} \mathrm{SI}\right)$. A. 0-50 m CCSF-A. (Continued on next six pages.)

A
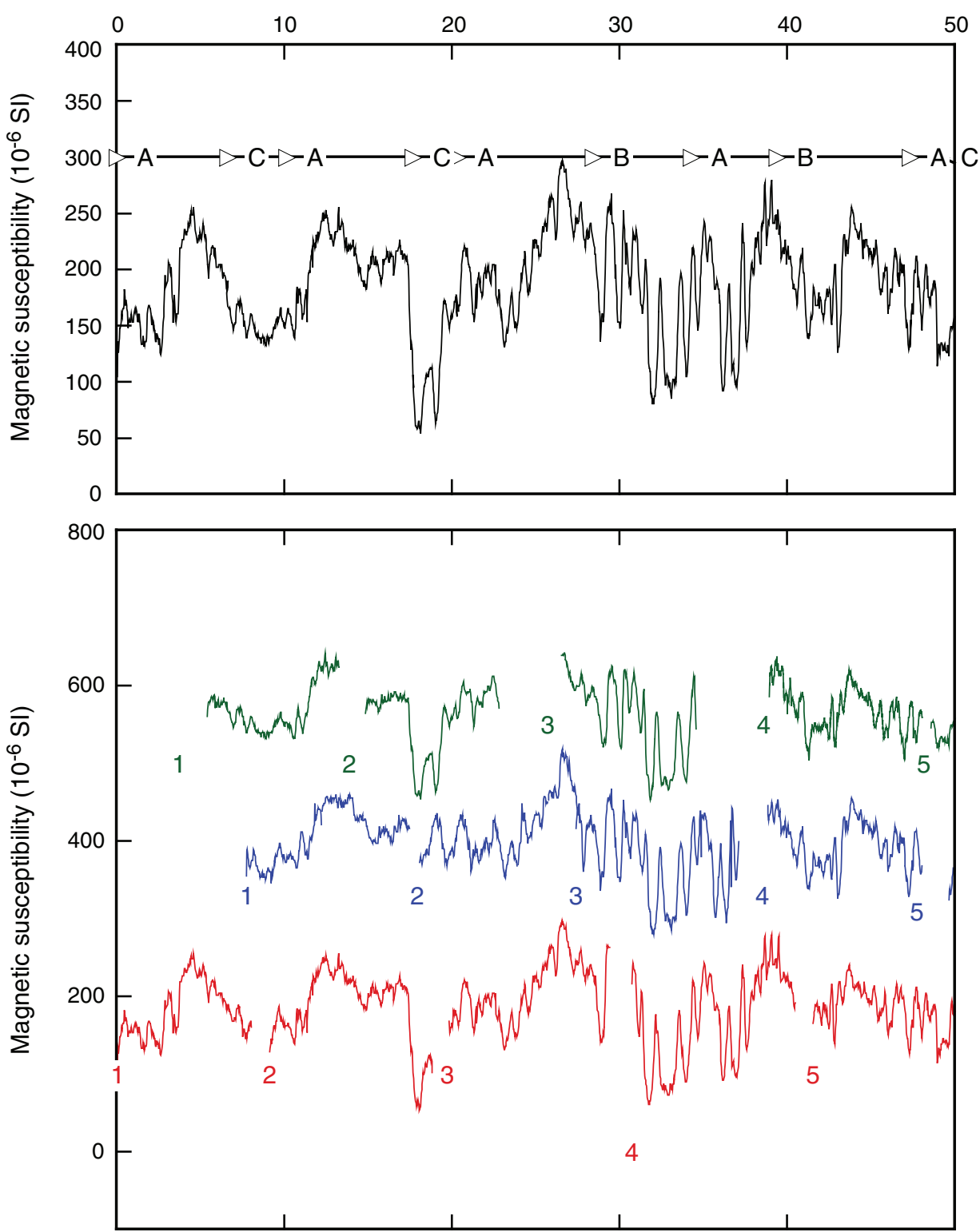
Figure F33 (continued). B. 50-100 m CCSF-A. (Continued on next page.)
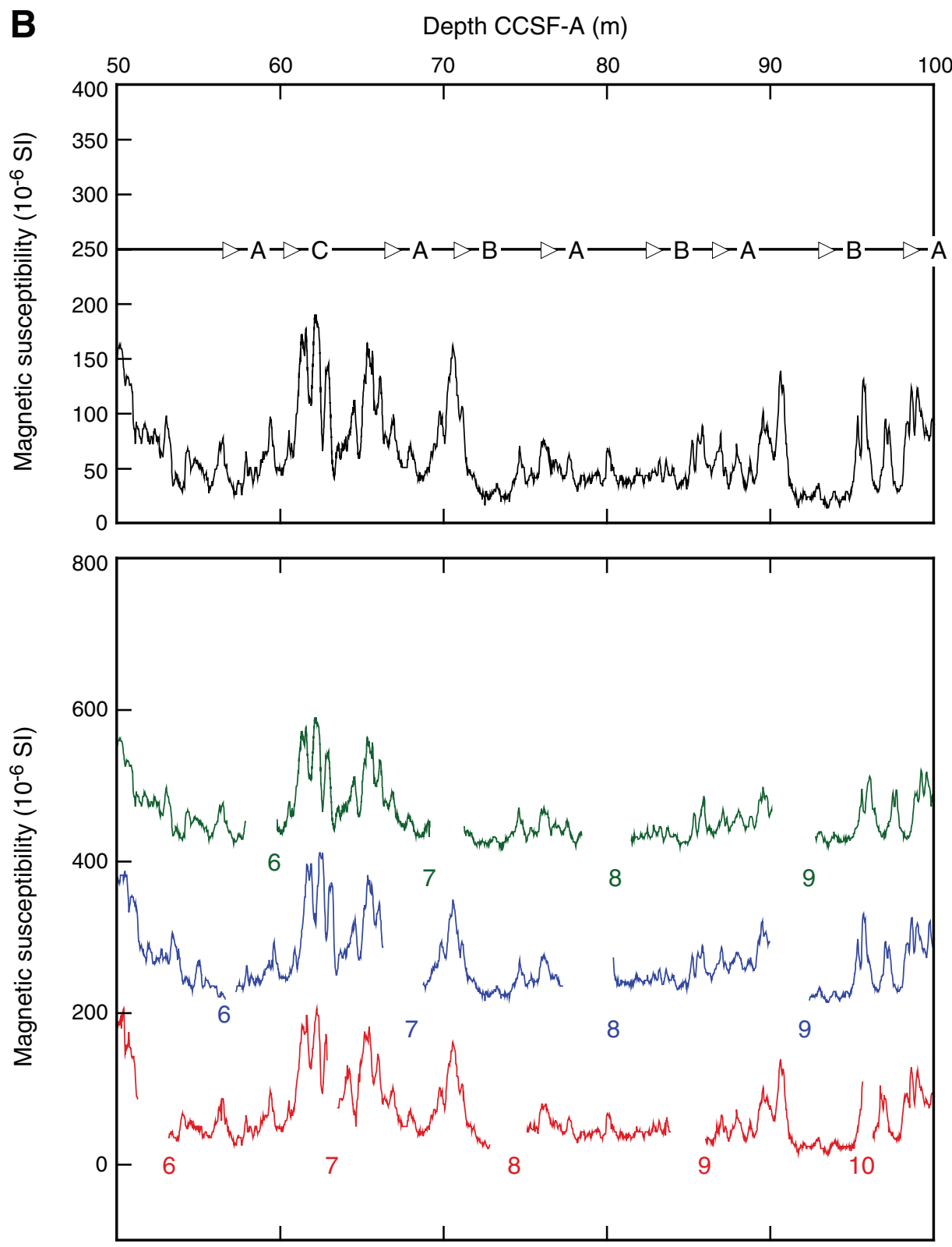
Figure F33 (continued). C. 100-150 m CCSF-A. (Continued on next page.)
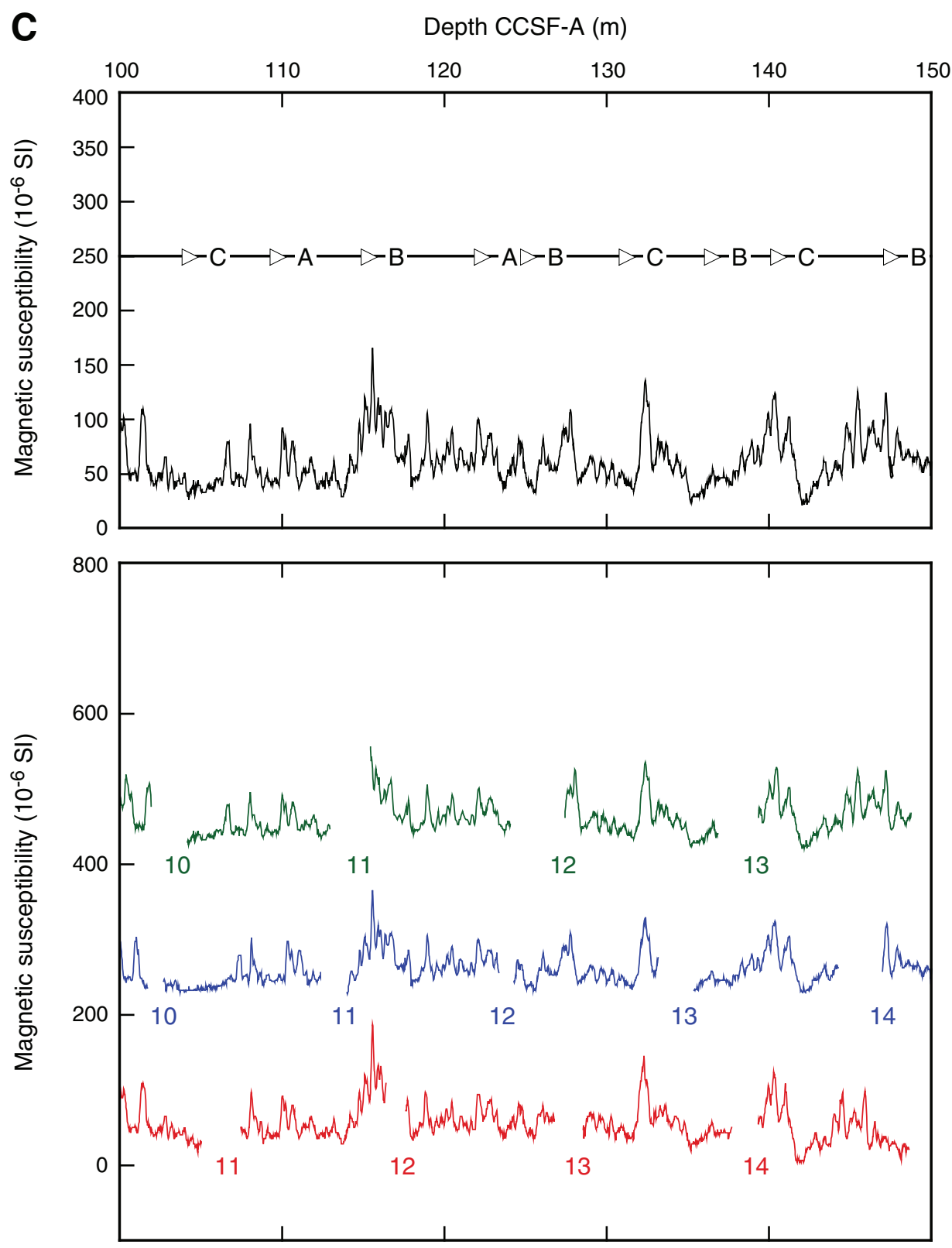
Figure F33 (continued). D. 150-200 m CCSF-A. (Continued on next page.)

D
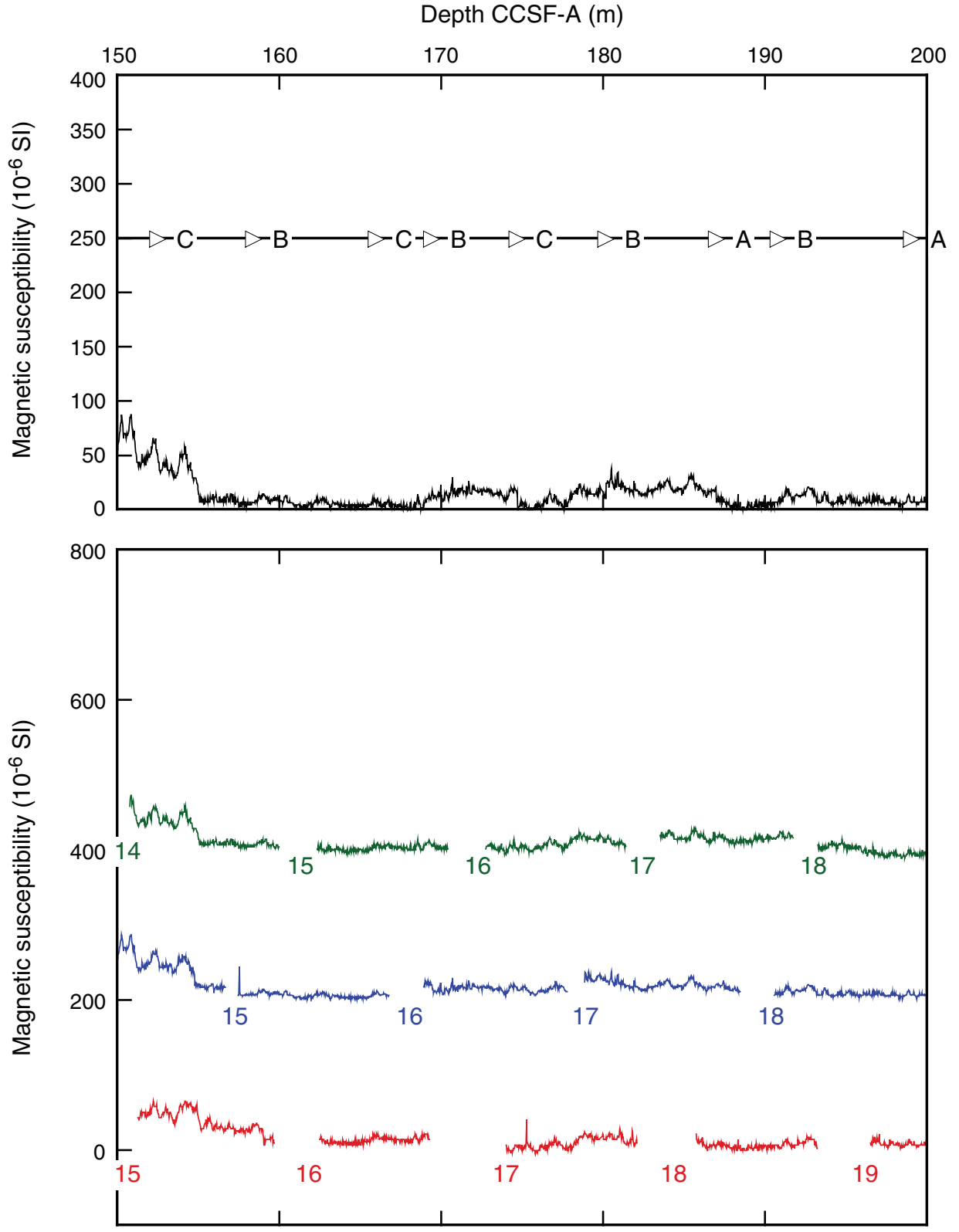
Figure F33 (continued). E. 200-250 m CCSF-A. (Continued on next page.)
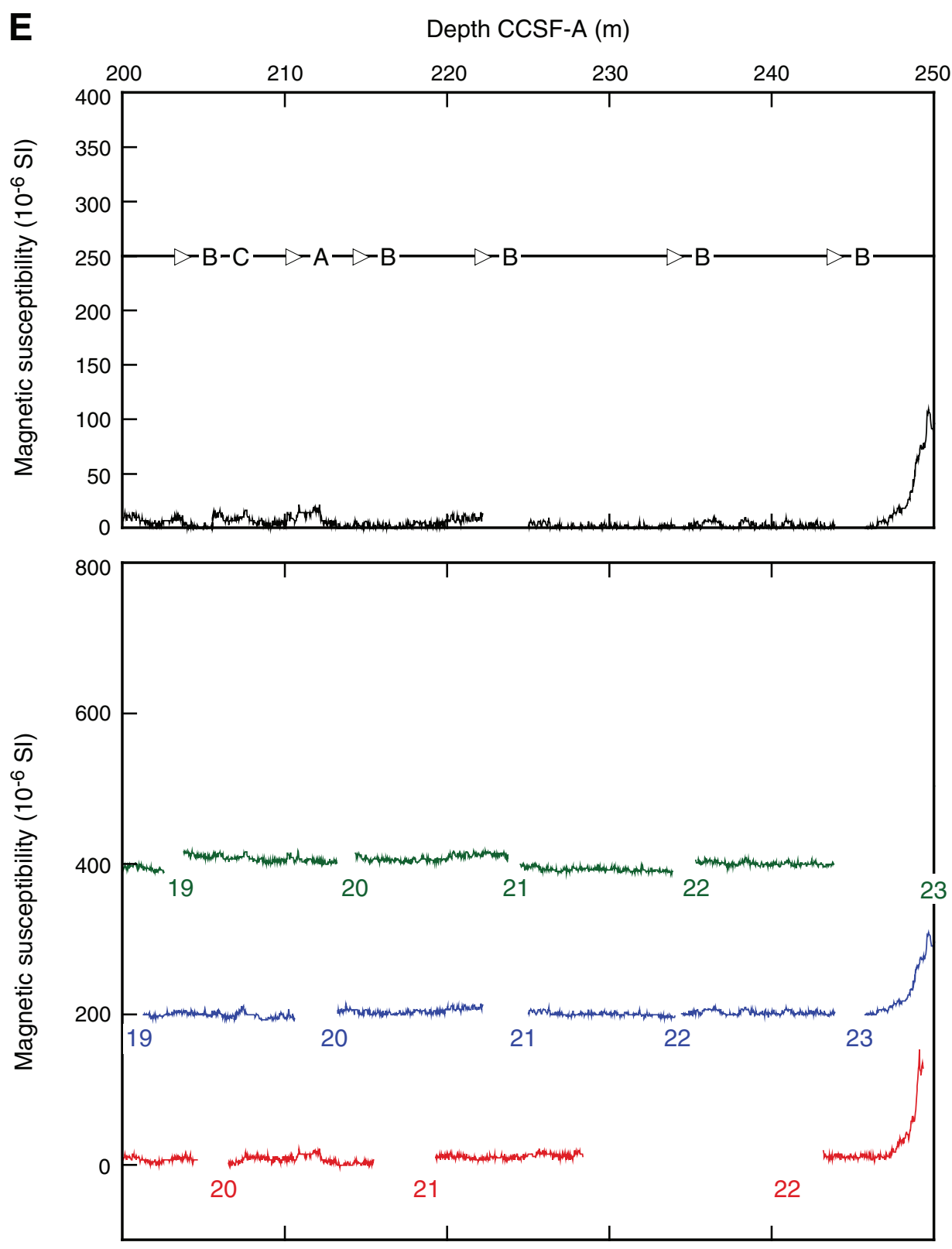
Figure F33 (continued). F. 250-300 m CCSF-A. (Continued on next page.)
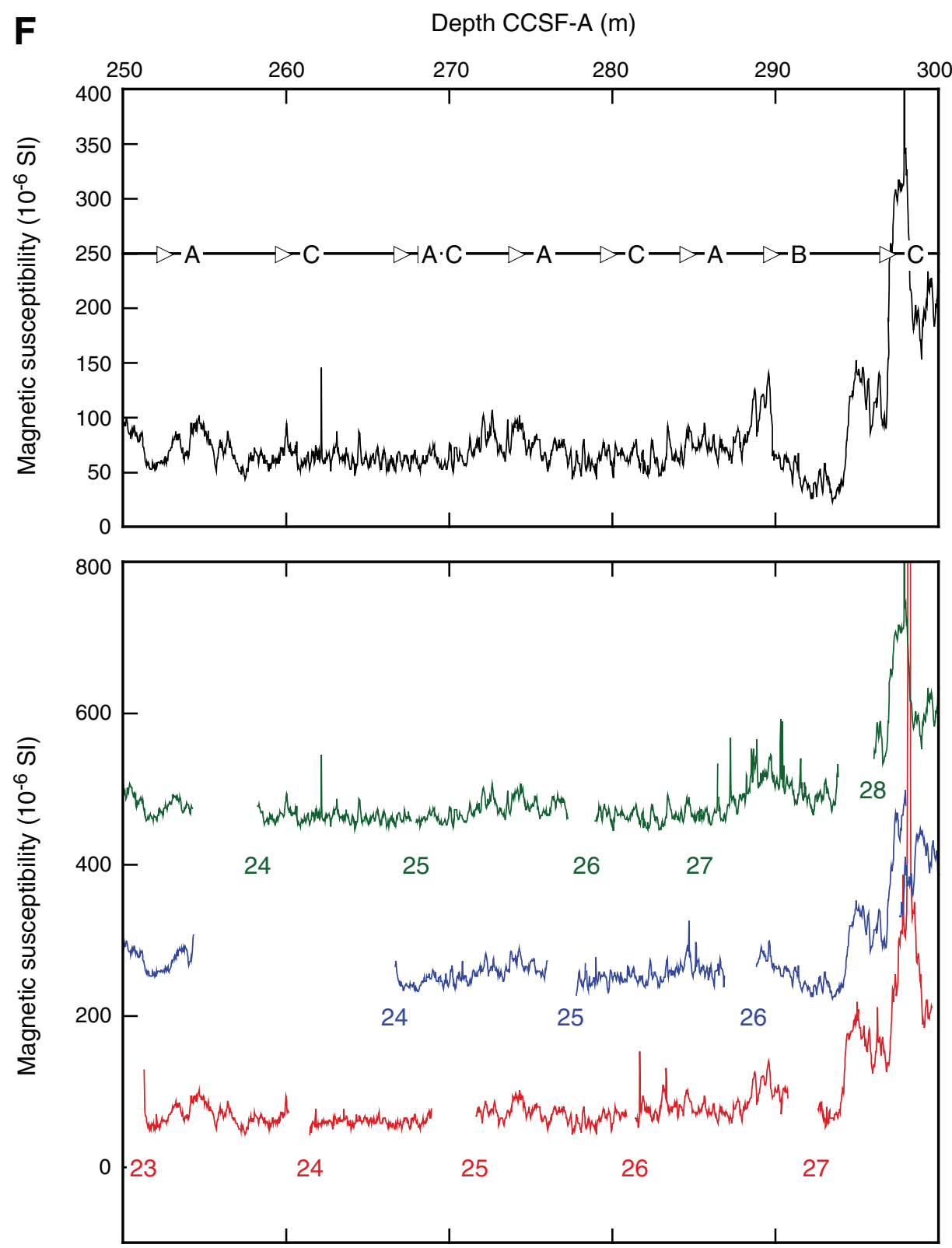
Figure F33 (continued). G. 300-350 m CCSF-A.
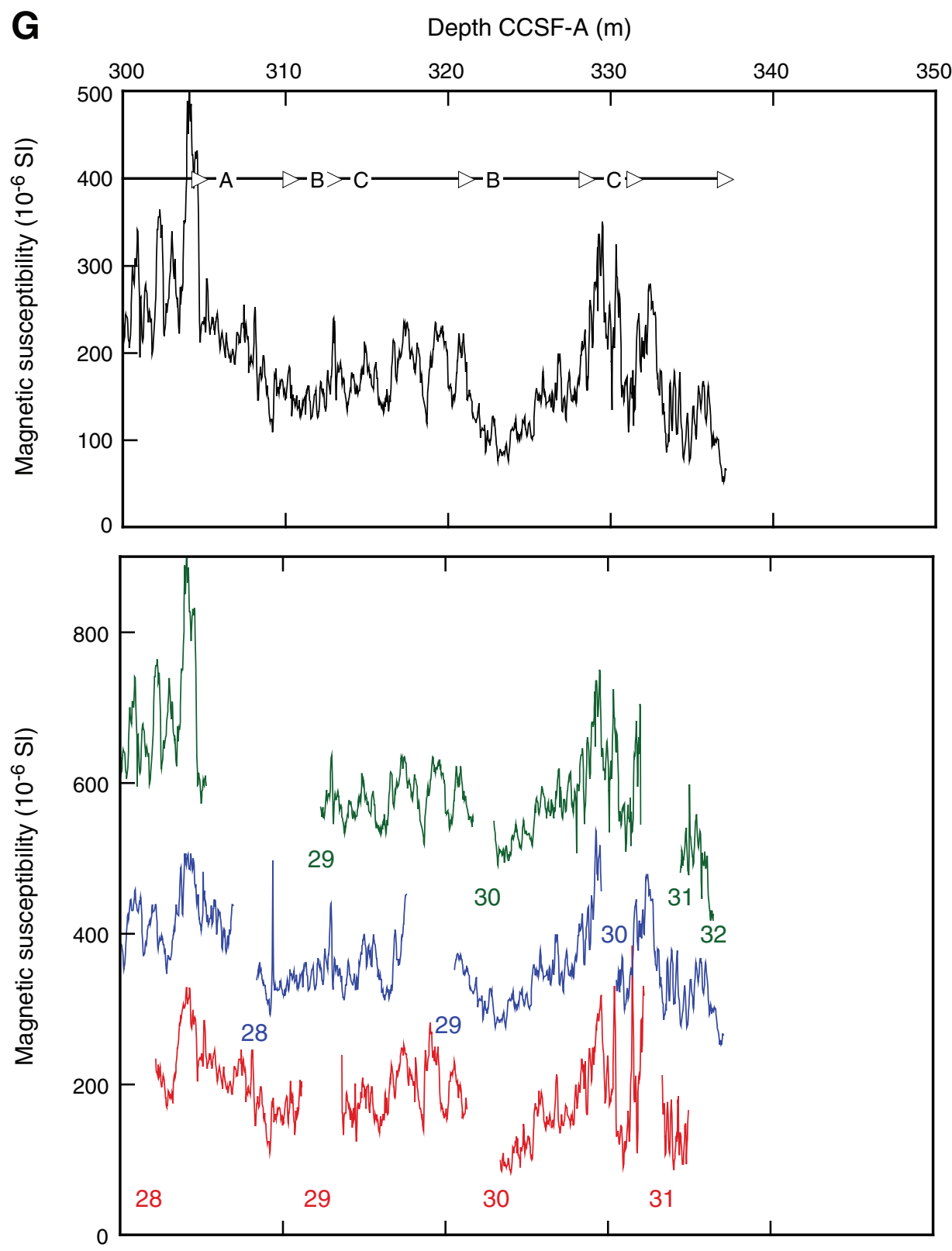
Figure F34. Gamma ray attenuation (GRA) density data, Site U1334. Top panel = spliced section with core breaks (triangles) and hole designations, bottom panel = Holes U1334A (red), U1334B (blue), and U1334C (green), offset from each other by a constant $\left(0.5 \mathrm{~g} / \mathrm{cm}^{3}\right)$. A. $0-50 \mathrm{~m}$ CCSF-A. (Continued on next six pages.)
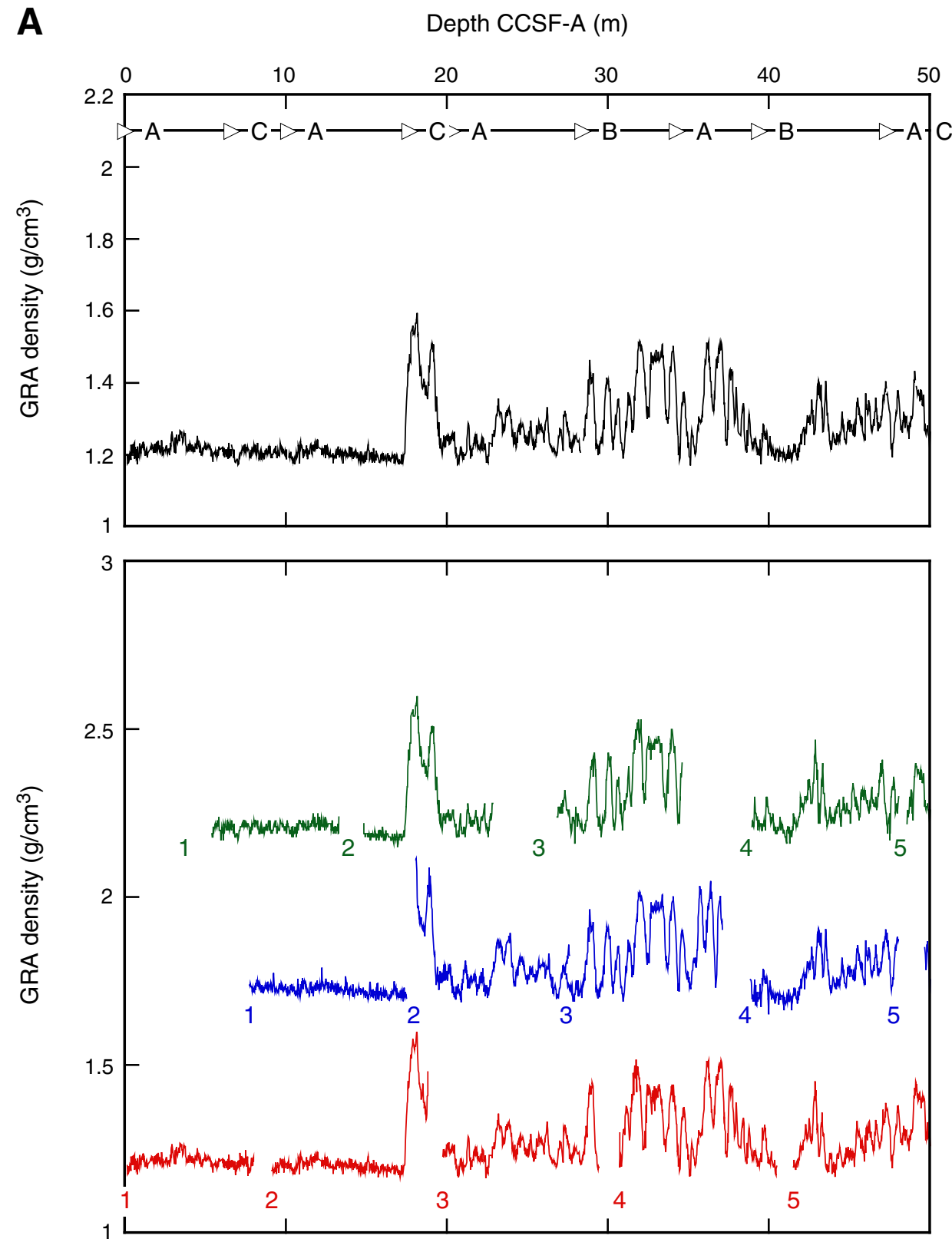
Figure F34 (continued). B. 50-100 m CCSF-A. (Continued on next page.)
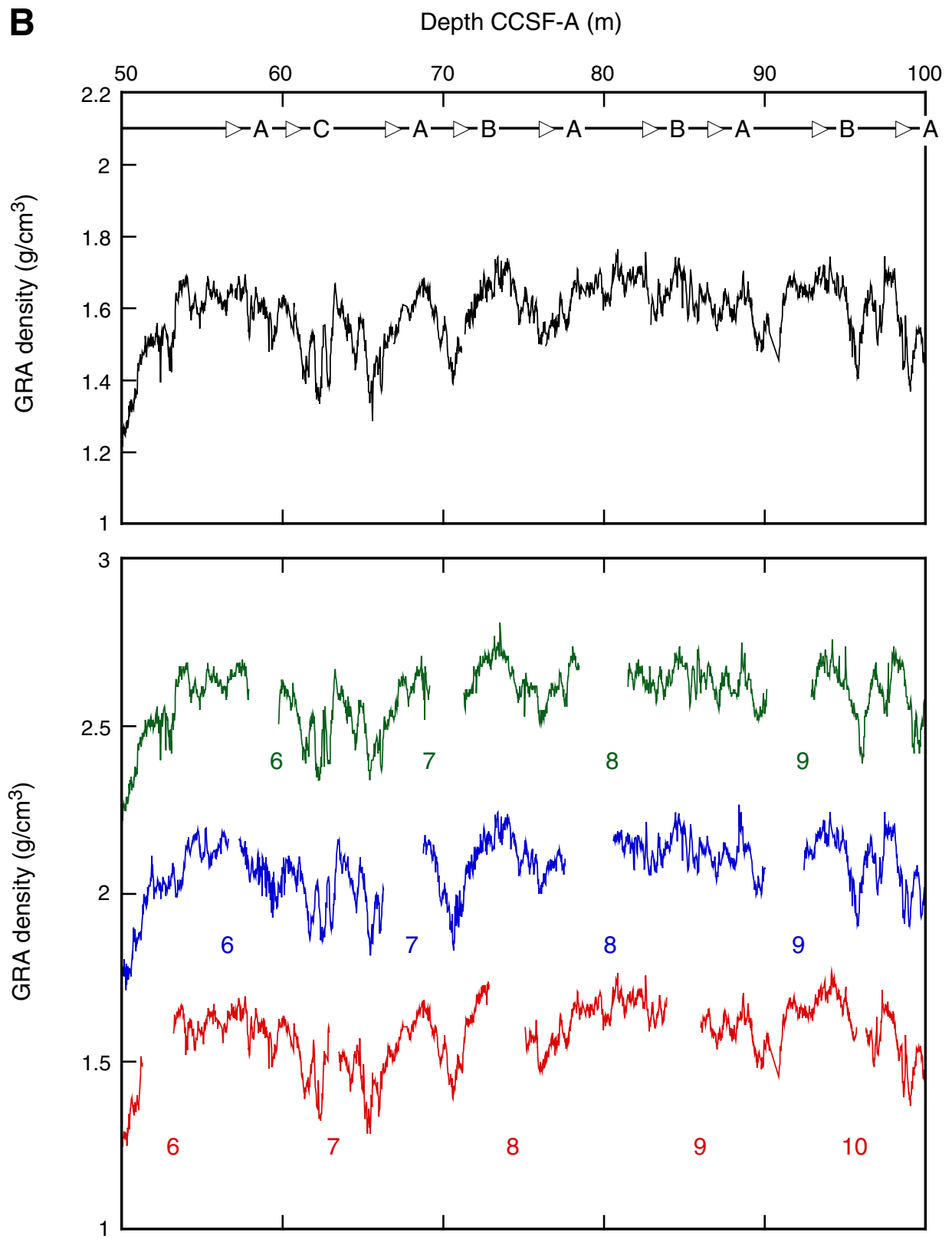
Figure F34 (continued). C. 100-150 m CCSF-A. (Continued on next page.)

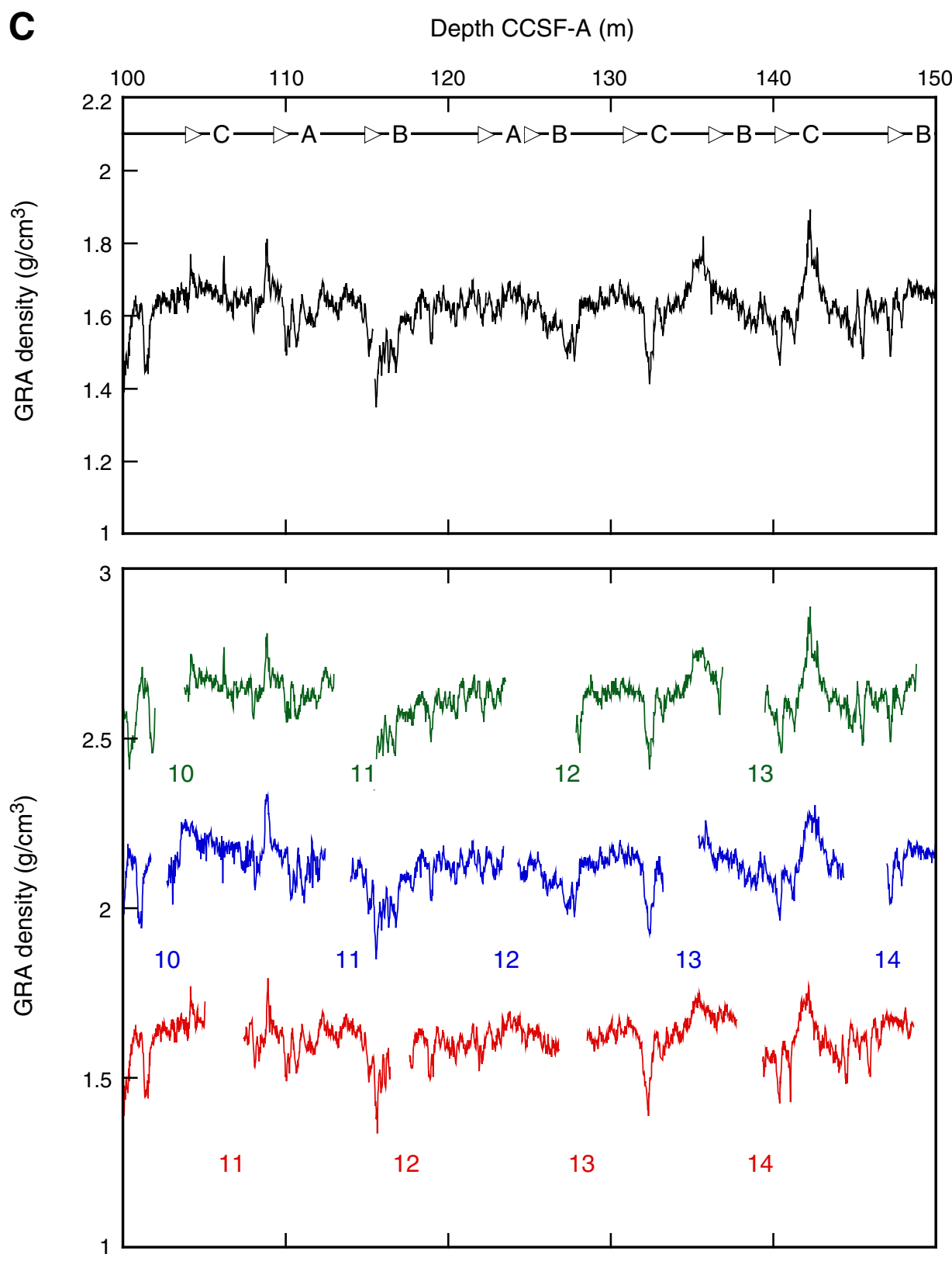


Figure F34 (continued). D. 150-200 m CCSF-A. (Continued on next page.)
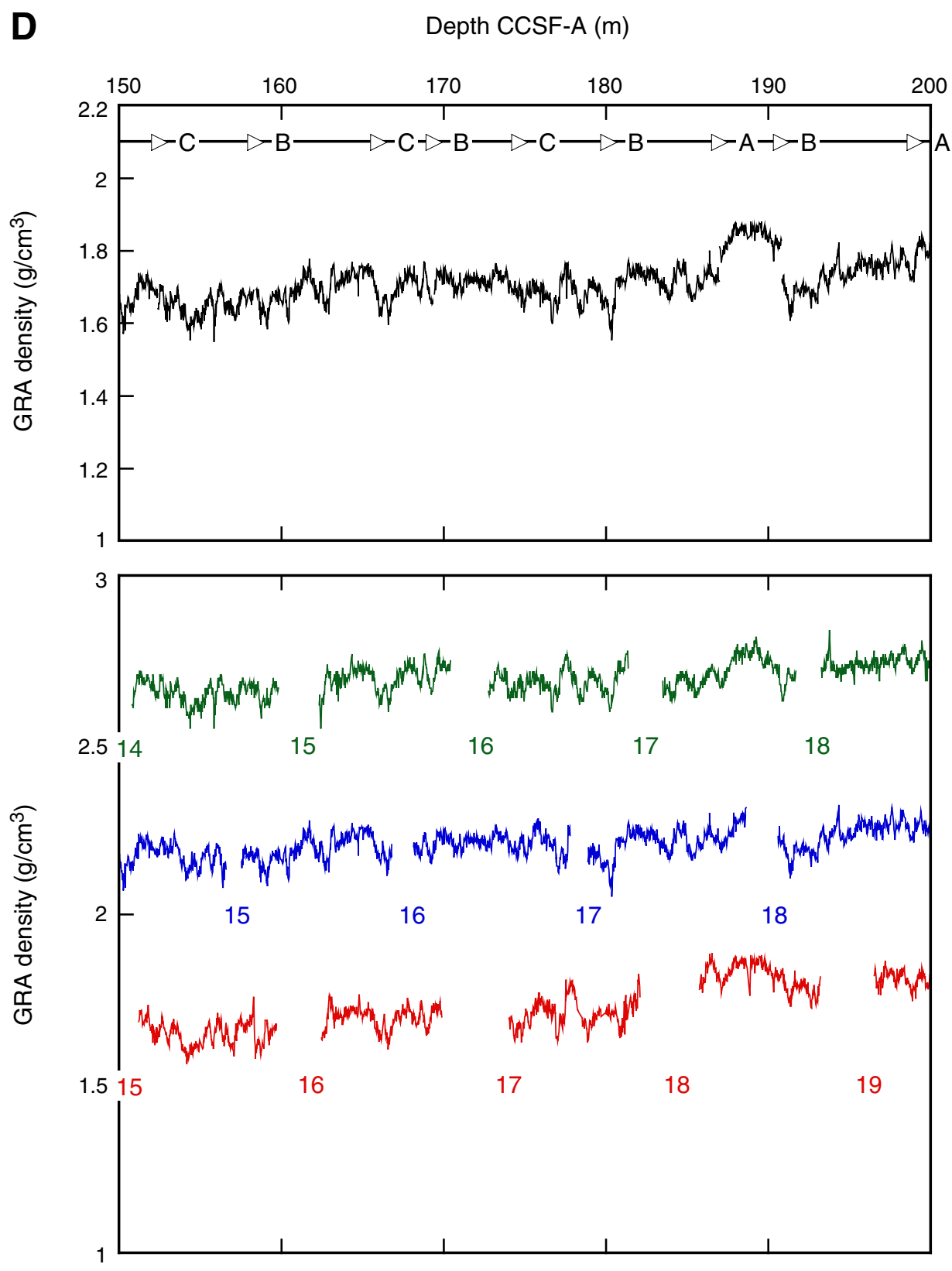
Figure F34 (continued). E. 200-250 m CCSF-A. (Continued on next page.)

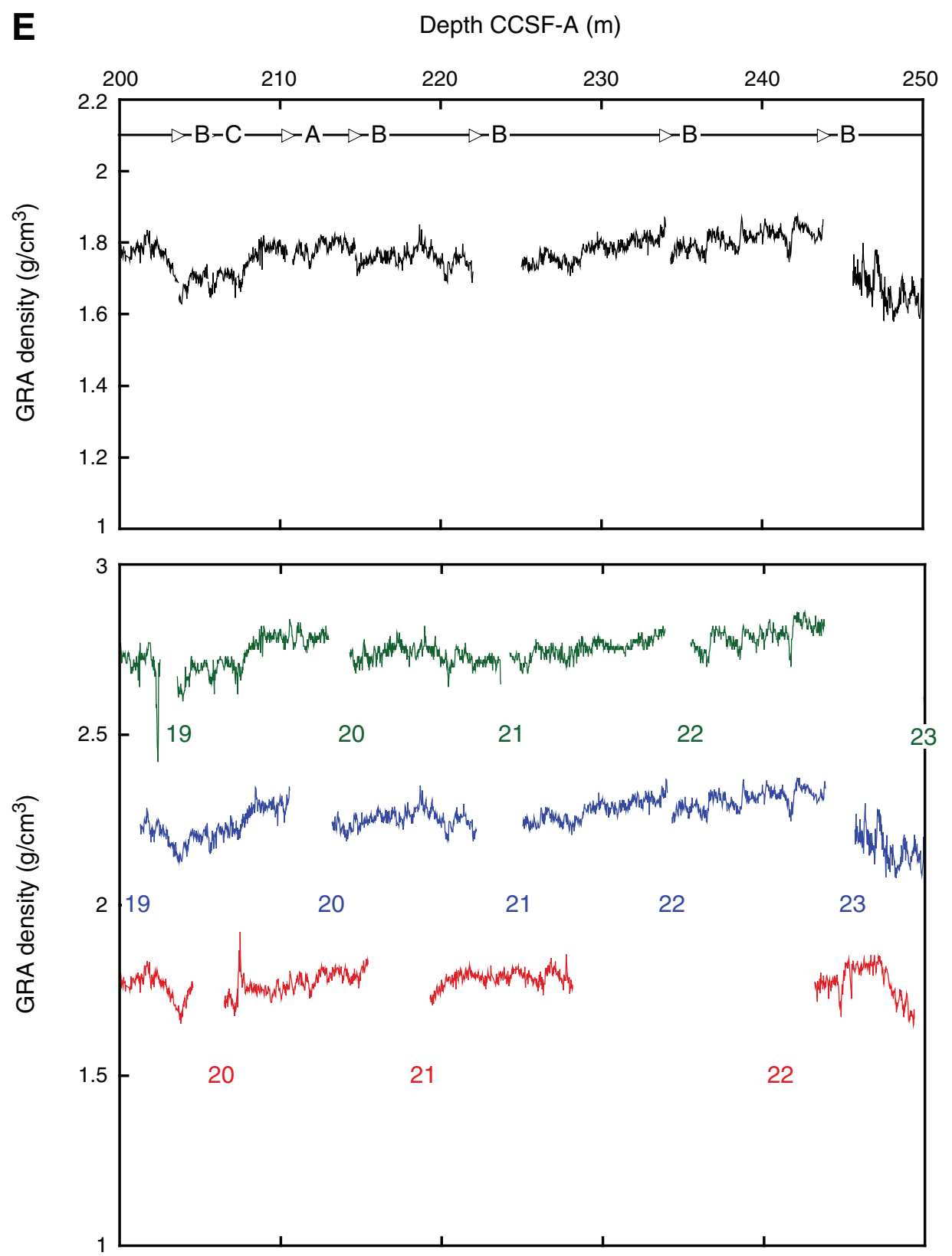


Figure F34 (continued). F. 250-300 m CCSF-A. (Continued on next page.)

$\mathbf{F}$

Depth CCSF-A (m)
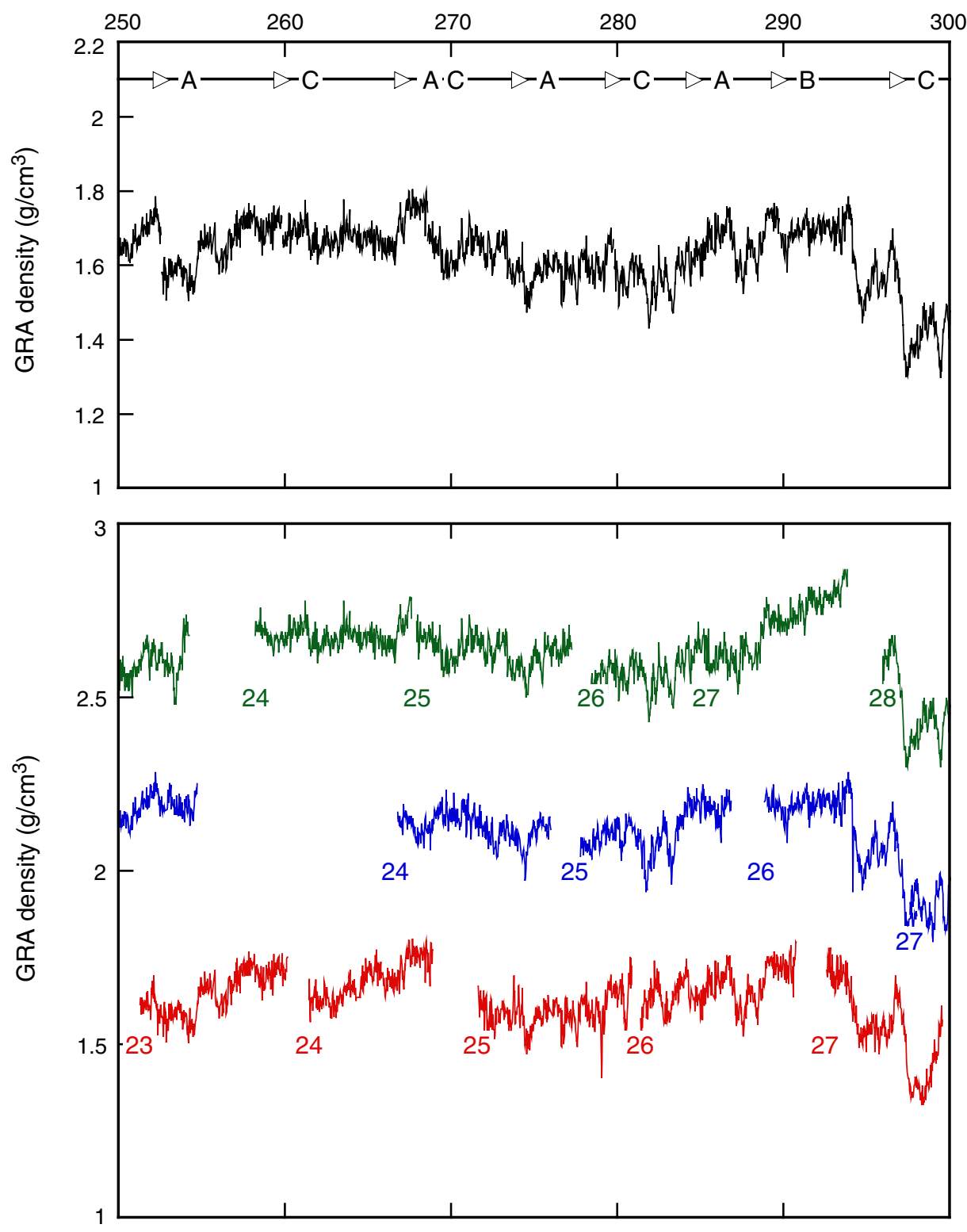
Figure F34 (continued). G. 300-350 m CCSF-A.

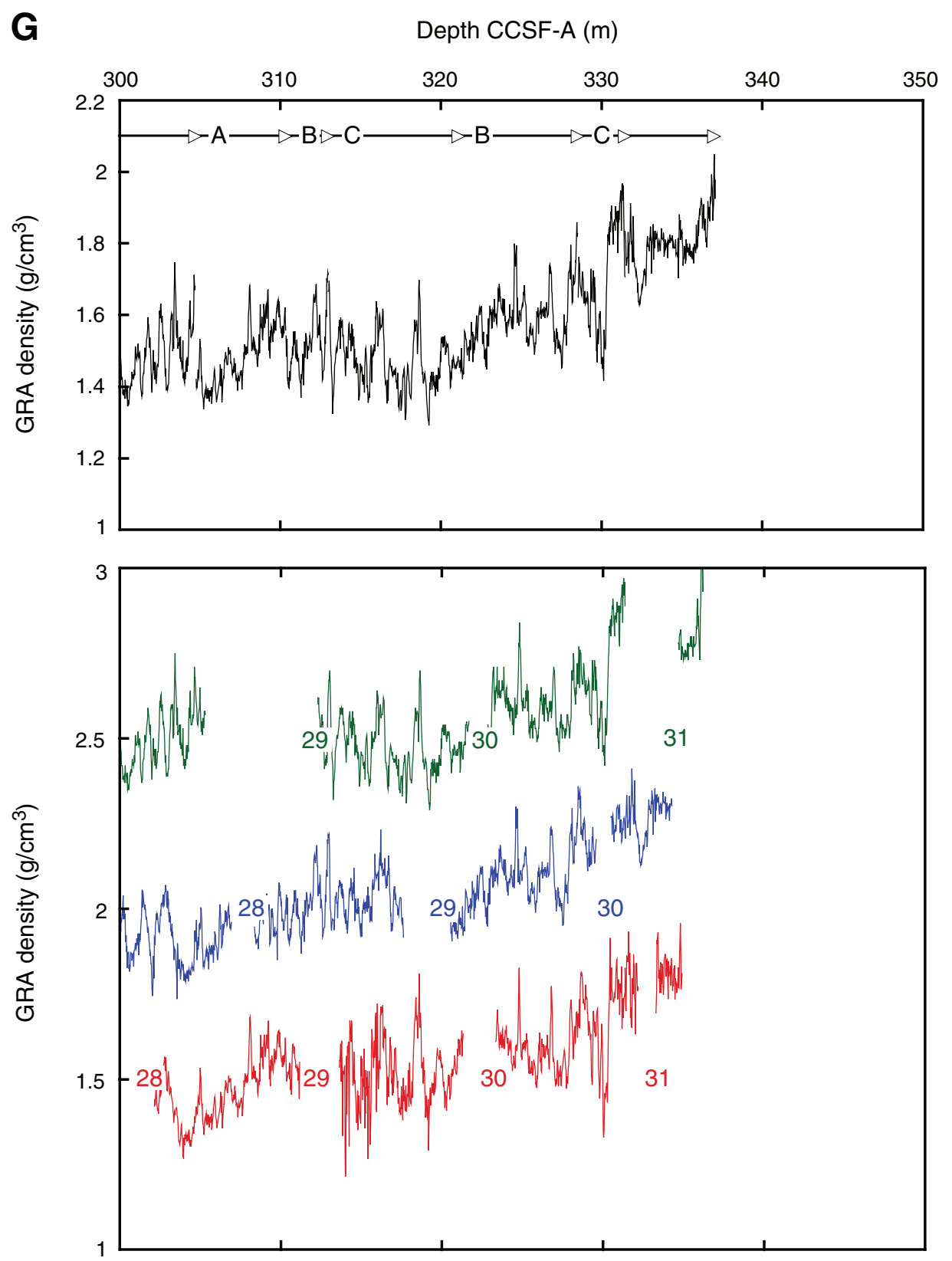


Figure F35. CSF depth vs. CCSF-A depth for tops of cores, Site U1334. Growth factor = slope of the regression line. On average, CCSF-A depth of spliced section is $16 \%$ greater than CSF depth.

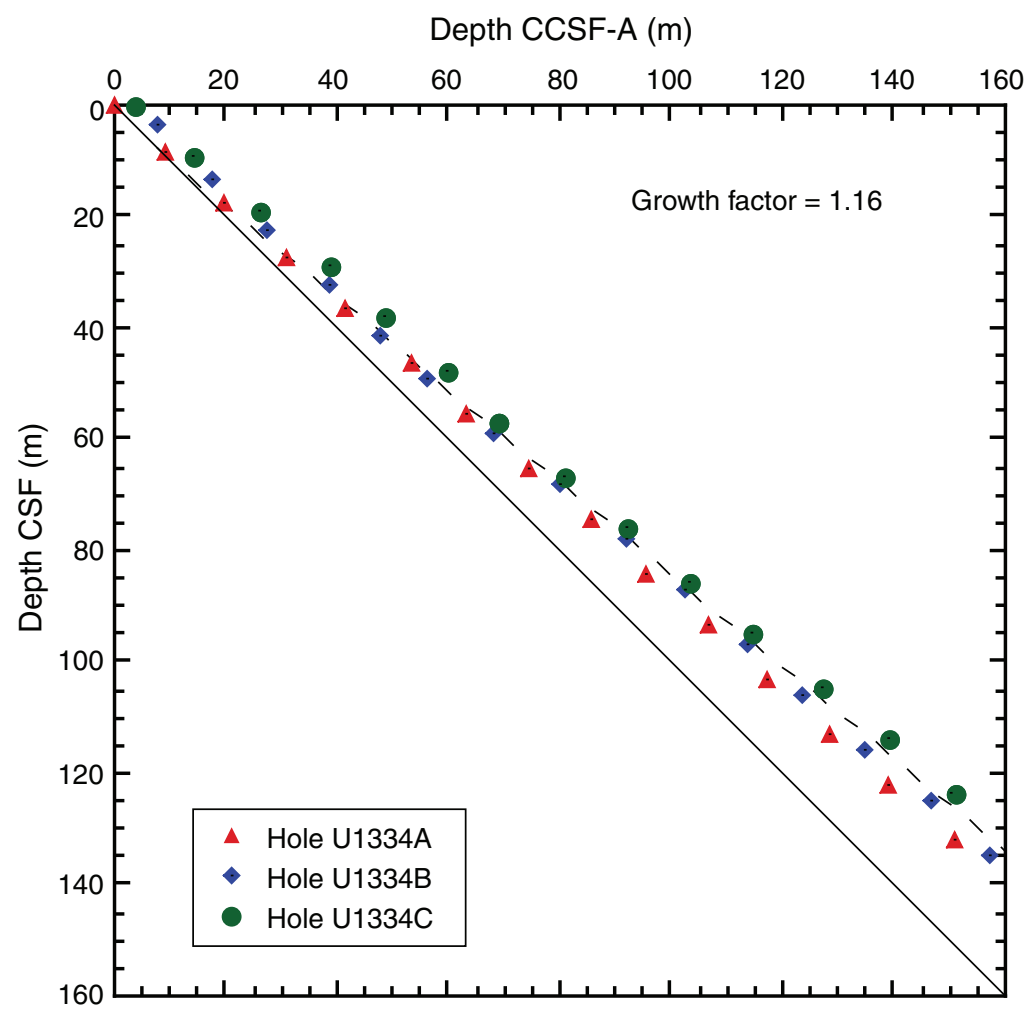


Figure F36. Heat flow calculation, Site U1334. A. Sediment temperatures, Hole U1334B. B. Thermal resistance based on laboratory thermal conductivity data, Hole U1334A. C. Bullard plot where heat flow is calculated from a linear fit of the temperature data. APCT-3 = advanced piston corer temperature tool.

A APCT-3 temperature $\left({ }^{\circ} \mathrm{C}\right)$

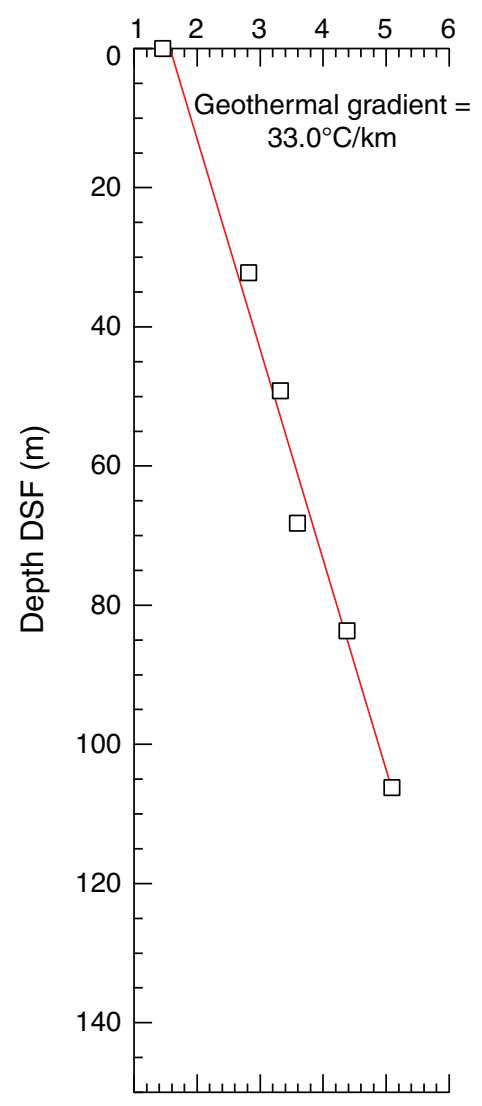

B

Thermal resistance $\left(\mathrm{m}^{2} \mathrm{~K} / \mathrm{W}\right)$

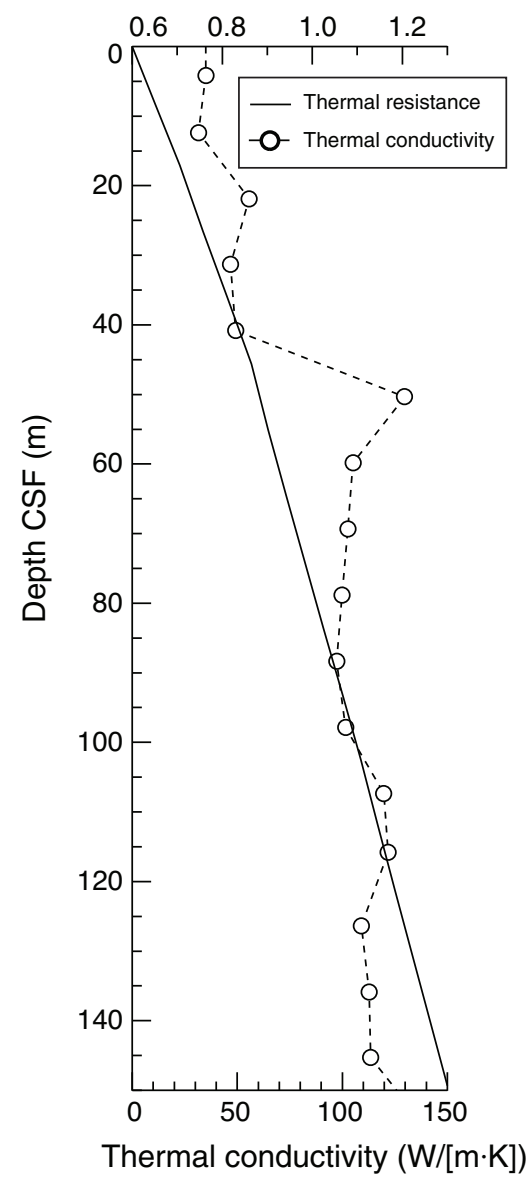

C APCT-3 temperature $\left({ }^{\circ} \mathrm{C}\right)$

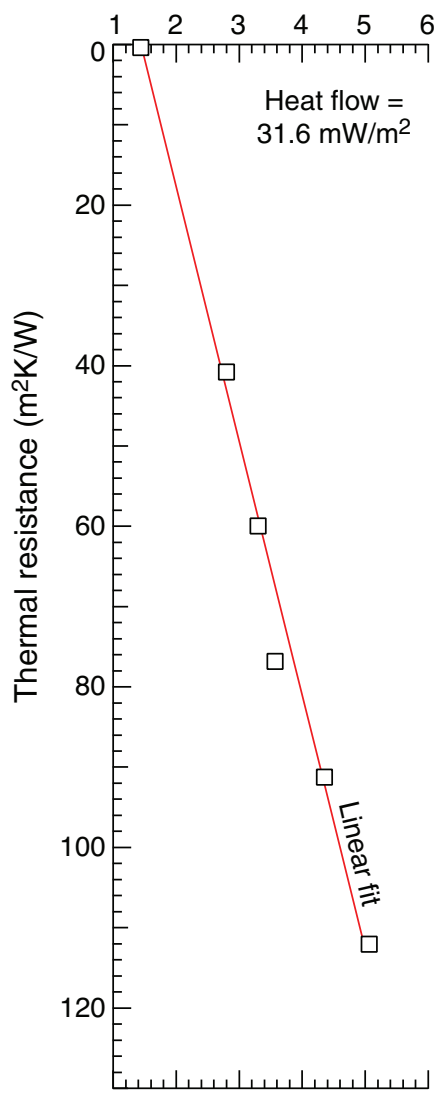


Table T1. Coring summary, Site U1334. (See table notes.) (Continued on next two pages.)

Site U1334

Time on site (h): 177.6 (1222 h, 6 April-2200 h, 13 April 2009)

Hole U1334A

Latitude: $7^{\circ} 59.998^{\prime} \mathrm{N}$

Longitude: $131^{\circ} 58.394^{\prime} \mathrm{W}$

Time on hole (h): 57.6 (1222 h, 6 April-2150 h, 8 April 2009)

Seafloor (drill pipe measurement below rig floor, $\mathrm{m}$ DRF): 4799.3

Distance between rig floor and sea level $(\mathrm{m}): 11.4$

Water depth (drill pipe measurement from sea level, mbsl): 4789.9

Total depth (drill pipe measurement from rig floor, $\mathrm{m}$ DRF): 5084.8

Total penetration (drilling depth below seafloor, m DSF): 285.5

Total length of cored section (m): 285.5

Total core recovered $(\mathrm{m}): 288.8$

Core recovery (\%): 102

Total number of cores: 32

Hole U1334B

Latitude: $7^{\circ} 59.998^{\prime} \mathrm{N}$

Longitude: $131^{\circ} 58.407^{\prime} \mathrm{W}$

Time on hole (h): 44.8 (2150 h, 8 April -1840 h, 10 April 2009)

Seafloor (drill pipe measurement below rig floor, $\mathrm{m} \mathrm{DRF):} 4799.3$

Distance between rig floor and sea level: $11.4 \mathrm{~m}$

Water depth (drill pipe measurement from sea level, mbsl): 4787.9

Total depth (drill pipe measurement from rig floor, m DRF): 5084.7

Total penetration (drilling depth below seafloor, $\mathrm{m} \mathrm{DSF}$ ): 285.4

Total length of cored section $(\mathrm{m}): 281.7$

Total core recovered $(\mathrm{m}): 294.6$

Core recovery (\%): 105

Total number of cores: 31

\section{Hole U1334C}

Latitude: $7^{\circ} 59.998^{\prime} \mathrm{N}$

Longitude: $131^{\circ} 58.422^{\prime} \mathrm{W}$

Time on hole (h): 75.3 (1840 h, 10 April-2200 h, 13 April 2009)

Seafloor (drill pipe measurement below rig floor, $\mathrm{m}$ DRF): 4801.0

Distance between rig floor and sea level: $11.4 \mathrm{~m}$

Water depth (drill pipe measurement from sea level, mbsl): 4789.6

Total depth (drill pipe measurement from rig floor, $\mathrm{m}$ DRF): 5081.7

Total penetration (drilling depth below seafloor, m DSF): 280.7

Total length of cored section (m): 280.7

Total core recovered $(\mathrm{m}): 285.8$

Core recovery (\%): 102

Total number of cores: 32

\begin{tabular}{|c|c|c|c|c|c|c|c|c|c|}
\hline \multirow[b]{2}{*}{ Core } & \multirow[b]{2}{*}{$\begin{array}{c}\text { Date } \\
(2009)\end{array}$} & \multirow[b]{2}{*}{$\begin{array}{l}\text { Local time } \\
\text { (h) }\end{array}$} & \multicolumn{2}{|c|}{ Depth DSF $(m)$} & \multirow[b]{2}{*}{$\begin{array}{l}\text { Interval } \\
\text { advanced } \\
(\mathrm{m})\end{array}$} & \multicolumn{2}{|c|}{ Depth CSF (m) } & \multirow[b]{2}{*}{$\begin{array}{l}\text { Length of core } \\
\text { recovered } \\
\text { (m) }\end{array}$} & \multirow[b]{2}{*}{$\begin{array}{l}\text { Recovery } \\
(\%)\end{array}$} \\
\hline & & & $\begin{array}{l}\text { Top of } \\
\text { cored } \\
\text { interval }\end{array}$ & $\begin{array}{l}\text { Bottom of } \\
\text { cored } \\
\text { interval }\end{array}$ & & $\begin{array}{l}\text { Top of } \\
\text { cored } \\
\text { interval }\end{array}$ & $\begin{array}{l}\text { Bottom of } \\
\text { cored } \\
\text { interval }\end{array}$ & & \\
\hline \multicolumn{10}{|c|}{ 320-U1334A- } \\
\hline $1 \mathrm{H}$ & $7 \mathrm{Apr}$ & 0110 & 0.0 & 8.2 & 8.2 & 0.00 & 8.24 & 8.24 & 100 \\
\hline $2 \mathrm{H}$ & $7 \mathrm{Apr}$ & 0215 & 8.2 & 17.7 & 9.5 & 8.20 & 18.16 & 9.96 & 105 \\
\hline $3 \mathrm{H}$ & $7 \mathrm{Apr}$ & 0345 & 17.7 & 27.2 & 9.5 & 17.70 & 27.70 & 10.00 & 105 \\
\hline $4 \mathrm{H}$ & $7 \mathrm{Apr}$ & 0450 & 27.2 & 36.7 & 9.5 & 27.20 & 37.23 & 10.03 & 106 \\
\hline $5 \mathrm{H}$ & $7 \mathrm{Apr}$ & 0550 & 36.7 & 46.2 & 9.5 & 36.70 & 46.83 & 10.13 & 107 \\
\hline $6 \mathrm{H}$ & $7 \mathrm{Apr}$ & 0740 & 46.2 & 55.7 & 9.5 & 46.20 & 56.25 & 10.05 & 106 \\
\hline $7 \mathrm{H}$ & $7 \mathrm{Apr}$ & 0845 & 55.7 & 65.2 & 9.5 & 55.70 & 65.71 & 10.01 & 105 \\
\hline $8 \mathrm{H}$ & $7 \mathrm{Apr}$ & 0945 & 65.2 & 74.7 & 9.5 & 65.20 & 75.11 & 9.91 & 104 \\
\hline $9 \mathrm{H}$ & $7 \mathrm{Apr}$ & 1050 & 74.7 & 84.2 & 9.5 & 74.70 & 84.79 & 10.09 & 106 \\
\hline $10 \mathrm{H}$ & $7 \mathrm{Apr}$ & 1155 & 84.2 & 93.7 & 9.5 & 84.20 & 94.00 & 9.80 & 103 \\
\hline $11 \mathrm{H}$ & $7 \mathrm{Apr}$ & 1300 & 93.7 & 103.2 & 9.5 & 93.70 & 103.80 & 10.10 & 106 \\
\hline $12 \mathrm{H}$ & $7 \mathrm{Apr}$ & 1410 & 103.2 & 112.7 & 9.5 & 103.20 & 112.66 & 9.65 & 100 \\
\hline $13 \mathrm{H}$ & $7 \mathrm{Apr}$ & 1530 & 112.7 & 122.2 & 9.5 & 112.70 & 122.60 & 9.90 & 104 \\
\hline $14 \mathrm{H}$ & $7 \mathrm{Apr}$ & 1620 & 122.2 & 131.7 & 9.5 & 122.20 & 132.01 & 9.81 & 103 \\
\hline $15 \mathrm{H}$ & $7 \mathrm{Apr}$ & 1720 & 131.7 & 141.2 & 9.5 & 131.70 & 141.25 & 9.55 & 101 \\
\hline $16 \mathrm{H}$ & $7 \mathrm{Apr}$ & 1830 & 141.2 & 150.7 & 9.5 & 141.20 & 149.62 & 8.42 & 89 \\
\hline $17 \mathrm{H}$ & $7 \mathrm{Apr}$ & 1945 & 150.7 & 160.2 & 9.5 & 150.70 & 160.75 & 8.31 & 106 \\
\hline $18 \mathrm{H}$ & $7 \mathrm{Apr}$ & 2200 & 160.2 & 169.7 & 9.5 & 160.20 & 170.22 & 10.02 & 105 \\
\hline $19 \mathrm{H}$ & $7 \mathrm{Apr}$ & 2310 & 169.7 & 179.2 & 9.5 & 169.70 & 178.54 & 8.84 & 93 \\
\hline $20 \mathrm{H}$ & $8 \mathrm{Apr}$ & 0050 & 179.2 & 188.7 & 9.5 & 179.20 & 188.68 & 9.48 & 100 \\
\hline $21 \mathrm{H}$ & $8 \mathrm{Apr}$ & 0245 & 188.7 & 198.2 & 9.5 & 188.70 & 198.53 & 9.83 & 103 \\
\hline $22 \mathrm{H}$ & $8 \mathrm{Apr}$ & 0445 & 198.2 & 206.9 & 8.7 & 198.20 & 206.91 & 8.71 & 100 \\
\hline
\end{tabular}


Table T1 (continued). (Continued on next page.)

\begin{tabular}{|c|c|c|c|c|c|c|c|c|c|}
\hline \multirow[b]{2}{*}{ Core } & \multirow[b]{2}{*}{$\begin{array}{c}\text { Date } \\
\text { (2009) }\end{array}$} & \multirow[b]{2}{*}{$\begin{array}{l}\text { Local time } \\
\text { (h) }\end{array}$} & \multicolumn{2}{|c|}{ Depth DSF (m) } & \multirow[b]{2}{*}{$\begin{array}{l}\text { Interval } \\
\text { advanced } \\
(\mathrm{m})\end{array}$} & \multicolumn{2}{|c|}{ Depth CSF (m) } & \multirow[b]{2}{*}{$\begin{array}{l}\text { Length of core } \\
\text { recovered } \\
(\mathrm{m})\end{array}$} & \multirow[b]{2}{*}{$\begin{array}{c}\text { Recovery } \\
(\%)\end{array}$} \\
\hline & & & $\begin{array}{l}\text { Top of } \\
\text { cored } \\
\text { interval }\end{array}$ & $\begin{array}{l}\text { Bottom of } \\
\text { cored } \\
\text { interval }\end{array}$ & & $\begin{array}{l}\text { Top of } \\
\text { cored } \\
\text { interval }\end{array}$ & $\begin{array}{l}\text { Bottom of } \\
\text { cored } \\
\text { interval }\end{array}$ & & \\
\hline $23 x$ & $8 \mathrm{Apr}$ & 0630 & 206.9 & 214.5 & 7.6 & 206.90 & 216.22 & 9.32 & 123 \\
\hline $24 X$ & $8 \mathrm{Apr}$ & 0745 & 214.5 & 224.1 & 9.6 & 214.50 & 224.27 & 9.77 & 102 \\
\hline $25 x$ & $8 \mathrm{Apr}$ & 0905 & 224.1 & 233.6 & 9.5 & 224.10 & 233.84 & 9.74 & 103 \\
\hline $26 x$ & $8 \mathrm{Apr}$ & 1030 & 233.6 & 243.2 & 9.6 & 233.60 & 243.41 & 9.81 & 102 \\
\hline $27 x$ & $8 \mathrm{Apr}$ & 1200 & 243.2 & 252.8 & 9.6 & 243.20 & 250.79 & 7.59 & 79 \\
\hline $28 \mathrm{X}$ & $8 \mathrm{Apr}$ & 1330 & 252.8 & 262.4 & 9.6 & 252.80 & 262.76 & 9.96 & 104 \\
\hline $29 X$ & $8 \mathrm{Apr}$ & 1455 & 262.4 & 272.1 & 9.7 & 262.40 & 272.05 & 9.65 & 99 \\
\hline $30 x$ & $8 \mathrm{Apr}$ & 1615 & 272.1 & 281.8 & 9.7 & 272.10 & 281.75 & 9.65 & 99 \\
\hline $31 x$ & $8 \mathrm{Apr}$ & 1800 & 281.8 & 285.0 & 3.2 & 281.80 & 283.94 & 2.14 & 67 \\
\hline \multirow[t]{3}{*}{$32 x$} & $8 \mathrm{Apr}$ & 2005 & 285.0 & 285.5 & 0.5 & 285.00 & 285.36 & 0.36 & 72 \\
\hline & \multirow{2}{*}{\multicolumn{4}{|c|}{$\begin{array}{l}\text { Advanced total: } \\
\text { Total interval cored: }\end{array}$}} & 285.5 & & & 288.83 & 101 \\
\hline & & & & & 285.5 & & & & \\
\hline
\end{tabular}

320-U1334B-

\begin{tabular}{|c|c|c|c|c|c|c|c|c|c|}
\hline $1 \mathrm{H}$ & $8 \mathrm{Apr}$ & 2350 & 3.7 & 13.2 & 9.5 & 3.70 & 13.72 & 10.02 & 105 \\
\hline $2 \mathrm{H}$ & $9 \mathrm{Apr}$ & 0100 & 13.2 & 22.7 & 9.5 & 13.20 & 23.08 & 9.88 & 104 \\
\hline $3 \mathrm{H}$ & $9 \mathrm{Apr}$ & 0225 & 22.7 & 32.2 & 9.5 & 22.70 & 32.87 & 10.17 & 107 \\
\hline $4 \mathrm{H}$ & $9 \mathrm{Apr}$ & 0330 & 32.2 & 41.7 & 9.5 & 32.20 & 41.96 & 9.76 & 103 \\
\hline $5 \mathrm{H}$ & $9 \mathrm{Apr}$ & 0450 & 41.7 & 49.2 & 7.5 & 41.70 & 50.96 & 9.26 & 123 \\
\hline $6 \mathrm{H}$ & 9 Apr & 0600 & 49.2 & 58.7 & 9.5 & 49.20 & 59.23 & 10.03 & 106 \\
\hline $7 \mathrm{H}$ & $9 \mathrm{Apr}$ & 0715 & 58.7 & 68.2 & 9.5 & 58.70 & 68.91 & 10.21 & 107 \\
\hline $8 \mathrm{H}$ & $9 \mathrm{Apr}$ & 0820 & 68.2 & 77.7 & 9.5 & 68.20 & 78.07 & 9.87 & 104 \\
\hline $9 \mathrm{H}$ & $9 \mathrm{Apr}$ & 0935 & 77.7 & 87.2 & 9.5 & 77.70 & 87.73 & 10.03 & 106 \\
\hline $10 \mathrm{H}$ & $9 \mathrm{Apr}$ & 1040 & 87.2 & 96.7 & 9.5 & 87.20 & 97.25 & 10.05 & 106 \\
\hline $11 \mathrm{H}$ & $9 \mathrm{Apr}$ & 1200 & 96.7 & 106.2 & 9.5 & 96.70 & 106.74 & 10.04 & 106 \\
\hline $12 \mathrm{H}$ & $9 \mathrm{Apr}$ & 1305 & 106.2 & 115.7 & 9.5 & 106.20 & 116.19 & 9.99 & 105 \\
\hline $13 \mathrm{H}$ & $9 \mathrm{Apr}$ & 1425 & 115.7 & 125.2 & 9.5 & 115.70 & 125.64 & 9.94 & 105 \\
\hline $14 \mathrm{H}$ & $9 \mathrm{Apr}$ & 1530 & 125.2 & 134.7 & 9.5 & 125.20 & 135.35 & 10.15 & 107 \\
\hline $15 \mathrm{H}$ & $9 \mathrm{Apr}$ & 1645 & 134.7 & 144.2 & 9.5 & 134.70 & 144.64 & 9.94 & 105 \\
\hline $16 \mathrm{H}$ & $9 \mathrm{Apr}$ & 1755 & 144.2 & 153.7 & 9.5 & 144.20 & 154.27 & 10.07 & 106 \\
\hline $17 \mathrm{H}$ & $9 \mathrm{Apr}$ & 1905 & 153.7 & 163.2 & 9.5 & 153.70 & 163.73 & 10.03 & 106 \\
\hline $18 \mathrm{H}$ & $9 \mathrm{Apr}$ & 2030 & 163.2 & 172.7 & 9.5 & 163.20 & 173.28 & 10.08 & 106 \\
\hline $19 \mathrm{H}$ & $9 \mathrm{Apr}$ & 2220 & 172.7 & 182.2 & 9.5 & 172.70 & 182.69 & 9.99 & 105 \\
\hline $20 \mathrm{H}$ & $10 \mathrm{Apr}$ & 0010 & 182.2 & 191.7 & 9.5 & 182.20 & 191.58 & 9.38 & 99 \\
\hline $21 \mathrm{H}$ & $10 \mathrm{Apr}$ & 0145 & 191.7 & 201.2 & 9.5 & 191.70 & 201.31 & 9.61 & 101 \\
\hline $22 \mathrm{H}$ & $10 \mathrm{Apr}$ & 0335 & 201.2 & 210.7 & 9.5 & 201.20 & 211.13 & 9.93 & 105 \\
\hline $23 x$ & $10 \mathrm{Apr}$ & 0515 & 210.7 & 219.0 & 8.3 & 210.70 & 220.48 & 9.78 & 118 \\
\hline $24 X$ & $10 \mathrm{Apr}$ & 0720 & 219.0 & 228.6 & 9.6 & 219.00 & 228.73 & 9.73 & 101 \\
\hline $25 x$ & $10 \mathrm{Apr}$ & 0825 & 228.6 & 238.2 & 9.6 & 228.60 & 239.10 & 9.82 & 102 \\
\hline $26 x$ & $10 \mathrm{Apr}$ & 0935 & 238.2 & 247.8 & 9.6 & 238.20 & 247.90 & 9.70 & 101 \\
\hline $27 X$ & $10 \mathrm{Apr}$ & 1045 & 247.8 & 257.4 & 9.6 & 247.80 & 257.61 & 9.81 & 102 \\
\hline $28 X$ & $10 \mathrm{Apr}$ & 1200 & 257.4 & 267.0 & 9.6 & 257.40 & 267.34 & 9.94 & 104 \\
\hline $29 X$ & $10 \mathrm{Apr}$ & 1325 & 267.0 & 276.6 & 9.6 & 267.00 & 277.03 & 10.03 & 104 \\
\hline $30 x$ & $10 \mathrm{Apr}$ & 1510 & 276.6 & 283.9 & 7.3 & 276.60 & 283.83 & 7.23 & 99 \\
\hline $31 x$ & $10 \mathrm{Apr}$ & 1640 & 283.9 & 285.4 & 1.5 & 283.90 & 284.02 & 0.12 & 8 \\
\hline
\end{tabular}

320-U1334C-

$\begin{array}{rrrrrrrrrr}1 \mathrm{H} & 10 \mathrm{Apr} & 2020 & 0.0 & 9.5 & 9.5 & 0.00 & 9.83 & 9.83 & 103 \\ 2 \mathrm{H} & 10 \mathrm{Apr} & 2220 & 9.5 & 19.0 & 9.5 & 9.50 & 18.72 & 9.22 & 97 \\ 3 \mathrm{H} & 10 \mathrm{Apr} & 2330 & 19.0 & 28.5 & 9.5 & 19.00 & 28.12 & 9.12 & 96 \\ 4 \mathrm{H} & 11 \mathrm{Apr} & 0035 & 28.5 & 38.0 & 9.5 & 28.50 & 38.31 & 9.81 & 103 \\ 5 \mathrm{H} & 11 \mathrm{Apr} & 0140 & 38.0 & 47.5 & 9.5 & 38.00 & 48.03 & 10.03 & 106 \\ 6 \mathrm{H} & 11 \mathrm{Apr} & 0240 & 47.5 & 57.0 & 9.5 & 47.50 & 57.28 & 9.78 & 103 \\ 7 \mathrm{H} & 11 \mathrm{Apr} & 0340 & 57.0 & 66.5 & 9.5 & 57.00 & 66.64 & 9.64 & 101 \\ 8 \mathrm{H} & 11 \mathrm{Apr} & 0440 & 66.5 & 76.0 & 9.5 & 66.50 & 76.36 & 9.86 & 104 \\ 9 \mathrm{H} & 11 \mathrm{Apr} & 0540 & 76.0 & 85.5 & 9.5 & 76.00 & 85.82 & 9.82 & 103 \\ 10 \mathrm{H} & 11 \mathrm{Apr} & 0655 & 85.5 & 95.0 & 9.5 & 85.50 & 95.17 & 9.67 & 102 \\ 11 \mathrm{H} & 11 \mathrm{Apr} & 0800 & 95.0 & 104.5 & 9.5 & 95.00 & 104.62 & 9.62 & 101 \\ 12 \mathrm{H} & 11 \mathrm{Apr} & 0910 & 104.5 & 114.0 & 9.5 & 104.50 & 114.28 & 9.78 & 103 \\ 13 \mathrm{H} & 11 \mathrm{Apr} & 1005 & 114.0 & 123.5 & 9.5 & 114.00 & 123.85 & 9.85 & 104 \\ 14 \mathrm{H} & 11 \mathrm{Apr} & 1105 & 123.5 & 133.0 & 9.5 & 123.50 & 133.03 & 9.53 & 100 \\ 15 \mathrm{H} & 11 \mathrm{Apr} & 1210 & 133.0 & 142.5 & 9.5 & 133.00 & 142.59 & 9.50 & 100 \\ 16 \mathrm{H} & 11 \mathrm{Apr} & 1315 & 142.5 & 152.0 & 9.5 & 142.50 & 151.94 & 9.44 & 99 \\ 17 \mathrm{H} & 11 \mathrm{Apr} & 1420 & 152.0 & 161.5 & 9.5 & 152.00 & 161.52 & 9.52 & 100 \\ 18 \mathrm{H} & 11 \mathrm{Apr} & 1525 & 161.5 & 171.0 & 9.5 & 161.50 & 171.19 & 9.69 & 102 \\ 19 \mathrm{H} & 11 \mathrm{Apr} & 1650 & 171.0 & 180.5 & 9.5 & 171.00 & 180.76 & 9.76 & 103\end{array}$


Table T1 (continued).

\begin{tabular}{|c|c|c|c|c|c|c|c|c|c|}
\hline \multirow[b]{2}{*}{ Core } & \multirow[b]{2}{*}{$\begin{array}{c}\text { Date } \\
(2009)\end{array}$} & \multirow[b]{2}{*}{$\begin{array}{l}\text { Local time } \\
\text { (h) }\end{array}$} & \multicolumn{2}{|c|}{ Depth DSF (m) } & \multirow[b]{2}{*}{$\begin{array}{l}\text { Interval } \\
\text { advanced } \\
\text { (m) }\end{array}$} & \multicolumn{2}{|c|}{ Depth CSF (m) } & \multirow[b]{2}{*}{$\begin{array}{l}\text { Length of core } \\
\text { recovered } \\
\text { (m) }\end{array}$} & \multirow[b]{2}{*}{$\begin{array}{c}\text { Recovery } \\
(\%)\end{array}$} \\
\hline & & & $\begin{array}{l}\text { Top of } \\
\text { cored } \\
\text { interval }\end{array}$ & $\begin{array}{c}\text { Bottom of } \\
\text { cored } \\
\text { interval }\end{array}$ & & $\begin{array}{l}\text { Top of } \\
\text { cored } \\
\text { interval }\end{array}$ & $\begin{array}{l}\text { Bottom of } \\
\text { cored } \\
\text { interval }\end{array}$ & & \\
\hline $20 \mathrm{H}$ & $11 \mathrm{Apr}$ & 1800 & 180.5 & 190.0 & 9.5 & 180.50 & 190.02 & 9.52 & 100 \\
\hline $21 \mathrm{H}$ & $11 \mathrm{Apr}$ & 2010 & 190.0 & 199.5 & 9.5 & 190.00 & 199.97 & 9.97 & 105 \\
\hline $22 \mathrm{H}$ & $11 \mathrm{Apr}$ & 2150 & 199.5 & 209.0 & 9.5 & 199.50 & 209.41 & 9.91 & 104 \\
\hline $23 x$ & $11 \mathrm{Apr}$ & 2315 & 209.0 & 214.0 & 5.0 & 209.00 & 213.61 & 4.61 & 92 \\
\hline $24 X$ & $12 \mathrm{Apr}$ & 0040 & 214.0 & 223.6 & 9.6 & 214.00 & 223.89 & 9.89 & 103 \\
\hline $25 x$ & $12 \mathrm{Apr}$ & 0200 & 223.6 & 233.2 & 9.6 & 223.60 & 233.35 & 9.75 & 102 \\
\hline $26 X$ & $12 \mathrm{Apr}$ & 0315 & 233.2 & 239.2 & 6.0 & 233.20 & 240.54 & 7.34 & 122 \\
\hline $27 X$ & $12 \mathrm{Apr}$ & 0440 & 239.2 & 248.8 & 9.6 & 239.20 & 248.16 & 8.96 & 93 \\
\hline $28 \mathrm{X}$ & $12 \mathrm{Apr}$ & 0610 & 248.8 & 258.4 & 9.6 & 248.80 & 258.62 & 9.82 & 102 \\
\hline $29 x$ & $12 \mathrm{Apr}$ & 0730 & 258.4 & 268.0 & 9.6 & 258.40 & 268.10 & 9.70 & 101 \\
\hline $30 x$ & $12 \mathrm{Apr}$ & 0855 & 268.0 & 277.7 & 9.7 & 268.00 & 277.96 & 9.96 & 103 \\
\hline $31 x$ & $12 \mathrm{Apr}$ & 1115 & 277.7 & 279.7 & 2.0 & 277.70 & 280.11 & 2.41 & 121 \\
\hline $32 X$ & $12 \mathrm{Apr}$ & 1310 & 279.7 & 280.2 & 0.5 & 279.70 & 280.17 & 0.47 & 94 \\
\hline \multirow[t]{2}{*}{$33 x$} & $12 \mathrm{Apr}$ & 1505 & 280.2 & 280.7 & 0.5 & 280.20 & 280.20 & 0.00 & 0 \\
\hline & & & \multicolumn{2}{|c|}{ Advanced total: } & $\begin{array}{l}280.7 \\
280.7\end{array}$ & & & 285.78 & 102 \\
\hline
\end{tabular}

Notes: $\mathrm{DRF}=$ drilling depth below rig floor, $\mathrm{DSF}=$ drilling depth below seafloor, $\mathrm{CSF}=$ core depth below seafloor. $\mathrm{H}=\mathrm{APC}$ core, $\mathrm{X}=\mathrm{XCB}$ core. Local time $=$ UTC $-10 \mathrm{~h}$.

Table T2. Lithologic unit boundaries, Site U1334. (See table notes.)

\begin{tabular}{|c|c|c|c|c|c|c|}
\hline Unit & $\begin{array}{l}\text { Core, section, } \\
\text { interval }(\mathrm{cm})\end{array}$ & $\begin{array}{l}\text { Depth } \\
\text { CSF (m) }\end{array}$ & $\begin{array}{l}\text { Core, section, } \\
\text { interval }(\mathrm{cm})\end{array}$ & $\begin{array}{l}\text { Depth } \\
\text { CSF (m) }\end{array}$ & $\begin{array}{l}\text { Core, section, } \\
\text { interval }(\mathrm{cm})\end{array}$ & $\begin{array}{l}\text { Depth } \\
\text { CSF (m) }\end{array}$ \\
\hline & 320-U1331A- & & 320-U1331B- & & 320-U1331C- & \\
\hline I & $5 \mathrm{H}-\mathrm{CC}, 25$ & 46.76 & $5 \mathrm{H}-3,55$ & 45.25 & $5 \mathrm{H}-1,65$ & 38.7 \\
\hline II & $27 X-2,26$ & 244.96 & $26 X-4,124$ & 243.94 & $27 X-6,96$ & 247.66 \\
\hline III & $31 \mathrm{X}-2,25^{*}$ & 283.55 & $31 X-5,30^{*}$ & 282.9 & $31 X-2,40$ & 279.41 \\
\hline IV & $32 \mathrm{X}-\mathrm{CC}, 43^{*}$ & 285.43 & $31 \mathrm{X}-\mathrm{CC}, 9^{*}$ & 283.99 & $32 \mathrm{X}-\mathrm{CC}, 43^{*}$ & 280.13 \\
\hline V & $32 \mathrm{X}-\mathrm{CC}, 40^{*}$ & 285.4 & $31 \mathrm{X}-\mathrm{CC}, 11^{*}$ & 284.01 & $32 \mathrm{X}-\mathrm{CC}, 49^{*}$ & 280.19 \\
\hline
\end{tabular}

Notes: Interval/depth are given for basal boundary of each unit. * = unit extends through at least given interval and depth, but boundary was not cored. 
Table T3. Calcareous nannofossil datums, Site U1334. (See table notes.)

\begin{tabular}{|c|c|c|c|c|c|c|c|}
\hline \multicolumn{2}{|c|}{ Core, section, interval $(\mathrm{cm})$} & \multirow[b]{2}{*}{ Marker species } & \multirow{2}{*}{$\begin{array}{l}\text { Age } \\
(\mathrm{Ma})\end{array}$} & \multicolumn{4}{|c|}{ Depth CSF $(m)$} \\
\hline Top & Bottom & & & Top & Bottom & Midpoint & \pm \\
\hline \multirow[t]{2}{*}{ 320-U1334A- } & $\begin{array}{c}320-U 1334 \mathrm{~A}- \\
2 \mathrm{H}-6,120\end{array}$ & Coronocyclus nitescens present & $>12.12$ & & $16.90^{*}$ & & \\
\hline & $2 \mathrm{H}-6,120$ & Calcidiscus premacintyrei present & $>12.45$ & & $16.90^{*}$ & & \\
\hline $3 \mathrm{H}-2,15$ & $3 \mathrm{H}-3,50$ & Tc Cyclicargolithus floridanus & 13.33 & 19.35 & 21.20 & 20.28 & 0.92 \\
\hline $3 \mathrm{H}-4,50$ & $3 \mathrm{H}-5,50$ & T Sphenolithus heteromorphus & 13.53 & 22.7 & 24.20 & 23.45 & 0.75 \\
\hline $3 \mathrm{H}-\mathrm{CC}$ & $4 \mathrm{H}-2,70$ & Tc Discoaster deflandrei & 15.66 & 27.65 & 29.40 & 28.53 & 0.88 \\
\hline $3 \mathrm{H}-\mathrm{CC}$ & $4 \mathrm{H}-2,70$ & B Discoaster petaliformis & 15.70 & 27.65 & 29.40 & 28.53 & 0.88 \\
\hline $4 \mathrm{H}-6,20$ & $4 \mathrm{H}-7,15$ & B Sphenolithus heteromorphus & 17.71 & 34.90 & 36.35 & 35.63 & 0.73 \\
\hline $5 \mathrm{H}-3,100$ & $5 \mathrm{H}-4,120$ & T Triquetrorhabdulus carinatus & 18.28 & 40.70 & 42.40 & 41.55 & 0.85 \\
\hline $9 \mathrm{H}-3,20$ & $9 \mathrm{H}-4,100$ & Tc Triquetrorhabdulus carinatus & 22.1 & 77.90 & 80.20 & 79.05 & 1.15 \\
\hline $9 \mathrm{H}-7,30$ & 9H-CC & B Sphenolithus disbelemnos & 22.8 & 84.00 & 84.74 & 84.37 & 0.37 \\
\hline $10 \mathrm{H}-7,30$ & $10 \mathrm{H}-\mathrm{CC}$ & T Sphenolithus delphix & 23.1 & 93.50 & 93.95 & 93.73 & 0.23 \\
\hline $11 \mathrm{H}-1,20$ & $11 \mathrm{H}-2,20$ & B Sphenolithus delphix & 23.2 & 94.70 & 96.20 & 95.45 & 0.75 \\
\hline $12 \mathrm{H}-7,30$ & $12 \mathrm{H}-\mathrm{CC}$ & T Sphenolithus ciperoensis & 24.4 & 112.27 & 112.58 & 112.43 & 0.16 \\
\hline $12 \mathrm{H}-\mathrm{CC}$ & $13 \mathrm{H}-1,45$ & X T. longus/T. carinatus & 24.7 & 112.58 & 113.15 & 112.87 & 0.29 \\
\hline $12 \mathrm{H}-\mathrm{CC}$ & $13 \mathrm{H}-1,45$ & Tc Cyclicargolithus abisectus & 24.7 & 112.58 & 113.15 & 112.87 & 0.29 \\
\hline $16 \mathrm{H}-6,40$ & $16 \mathrm{H}-\mathrm{CC}$ & T Sphenolithus distentus & 26.8 & 149.10 & 149.57 & 149.34 & 0.23 \\
\hline $16 \mathrm{H}-6,40$ & $16 \mathrm{H}-\mathrm{CC}$ & T Sphenolithus predistentus & 26.9 & 149.10 & 149.57 & 149.34 & 0.23 \\
\hline $18 \mathrm{H}-\mathrm{CC}$ & $19 \mathrm{H}-\mathrm{CC}$ & B Sphenolithus ciperoensis & 27.1 & 170.17 & 178.49 & 174.33 & 4.16 \\
\hline $19 \mathrm{H}-\mathrm{CC}$ & $20 \mathrm{H}-\mathrm{CC}$ & T Sphenolithus pseudoradians & 28.8 & 178.49 & 188.63 & 183.56 & 5.07 \\
\hline $21 \mathrm{H}-\mathrm{CC}$ & $22 \mathrm{H}-2,70$ & B Sphenolithus distentus & 30.0 & 198.48 & 200.40 & 199.44 & 0.96 \\
\hline $24 \mathrm{X}-\mathrm{CC}$ & $25 X-1,80$ & T Reticulofenestra umbilicus & 32.0 & 224.22 & 224.90 & 224.56 & 0.34 \\
\hline $26 \mathrm{X}-\mathrm{CC}$ & $27 X-2,11$ & T Isthmolithus recurvus & 32.5 & 243.36 & 244.81 & 244.09 & 0.72 \\
\hline $26 X-2,100$ & $26 X-3,100$ & T Coccolithus formosus & 32.9 & 236.10 & 237.60 & 236.85 & 0.75 \\
\hline $27 X-5,150$ & $27 \mathrm{X}-\mathrm{CC}$ & T Discoaster saipanensis & 34.4 & 249.70 & 250.76 & 250.23 & 0.53 \\
\hline $28 \mathrm{X}-2,123$ & $28 \mathrm{X}-\mathrm{CC}$ & T Reticulofenestra reticulata & 35.2 & 255.53 & 262.62 & 259.08 & 3.55 \\
\hline $29 \mathrm{X}-\mathrm{CC}$ & $30 X-1,66$ & B Isthmolithus recurvus & 36.6 & 272.00 & 272.76 & 272.38 & 0.38 \\
\hline $30 X-1,66$ & $30 X-2,74$ & T Chiasmolithus oamaruensis & 37.0 & 272.76 & 274.34 & 273.55 & 0.79 \\
\hline \multirow[t]{2}{*}{$30 X-1,66$} & $30 \times-2,74$ & T Chiasmolithus grandis & 37.1 & 272.76 & 274.34 & 273.55 & 0.79 \\
\hline & $32 X-C C$ & Dictyococcites bisectus present & $<38.0$ & & $285.21^{\dagger}$ & & \\
\hline
\end{tabular}

Notes: $\mathrm{TC}=$ top common, $\mathrm{T}=$ top, $\mathrm{B}=$ bottom, $\mathrm{X}=$ abundance crossover. ${ }^{*}=$ occurrence of taxa in the uppermost nannofossiliferous sample provides a maximum estimate of bioevent depth only, $\dagger=$ occurrence of taxa in the lowest sample provides a maximum estimate of the age. 
Table T4. Radiolarian datums, Site U1334. (See table note.) (Continued on next page.)

\begin{tabular}{|c|c|c|c|c|c|c|c|c|c|}
\hline \multirow[b]{2}{*}{ Geologic age } & \multirow[b]{2}{*}{ Zone } & \multirow[b]{2}{*}{ Marker species } & \multirow{2}{*}{$\begin{array}{l}\text { Age } \\
(\mathrm{Ma})\end{array}$} & \multicolumn{2}{|c|}{ Core, section, interval $(\mathrm{cm})$} & \multicolumn{4}{|c|}{ Depth CSF (m) } \\
\hline & & & & Top & Bottom & Top & Bottom & Midpoint & \pm \\
\hline \multirow{36}{*}{ lower Miocene } & RN7 & T D. petterssoni & 8.63 & $\begin{array}{l}320-U 1334 \mathrm{~A}- \\
1 \mathrm{H}-4,105-107\end{array}$ & $\begin{array}{l}\text { 320-U1334A- } \\
1 \mathrm{H}-\mathrm{CC}\end{array}$ & 5.56 & 8.19 & 6.88 & 1.32 \\
\hline & & D. petterssoni $>D$. hughesi & 8.76 & & & & & & \\
\hline & \multirow{3}{*}{ RN6 } & B S. berminghami & 8.76 & $1 \mathrm{H}-\mathrm{CC}$ & $2 \mathrm{H}-2,105-107$ & 8.19 & 10.76 & 9.48 & 1.29 \\
\hline & & B D. hughesi & 8.99 & $1 \mathrm{H}-\mathrm{CC}$ & $2 \mathrm{H}-2,105-107$ & 8.19 & 10.76 & 9.48 & 1.29 \\
\hline & & B D. petterssoni & 12.11 & $2 \mathrm{H}-4,105-107$ & $2 \mathrm{H}-\mathrm{CC}$ & 13.76 & 18.11 & 15.94 & 2.18 \\
\hline & \multirow{3}{*}{ RN5 } & B L. neotera & 12.95 & $2 \mathrm{H}-\mathrm{CC}$ & $3 \mathrm{H}-2,105-107$ & 18.11 & 20.25 & 19.18 & 1.07 \\
\hline & & T S. armata & 13.50 & $3 \mathrm{H}-2,105-107$ & $3 \mathrm{H}-4,105-107$ & 20.25 & 23.25 & 21.75 & 1.50 \\
\hline & & T A. octopylus & 13.88 & $3 \mathrm{H}-2,105-107$ & $3 \mathrm{H}-4,105-107$ & 20.25 & 23.25 & 21.75 & 1.50 \\
\hline & & D. dentata $>$ D. alata & 14.78 & $3 \mathrm{H}-4,105-107$ & $3 \mathrm{H}-\mathrm{CC}$ & 23.25 & 27.65 & 25.45 & 2.20 \\
\hline & \multirow{6}{*}{ RN4 } & B D. alata & 15.08 & $3 \mathrm{H}-\mathrm{CC}$ & $4 \mathrm{H}-2,105-107$ & 27.65 & 29.76 & 28.71 & 1.06 \\
\hline & & B L. parkerae & 15.03 & $4 \mathrm{H}-2,105-107$ & $4 \mathrm{H}-4,105-107$ & 29.76 & 32.76 & 31.26 & 1.50 \\
\hline & & T C. cingulata & 15.13 & $4 \mathrm{H}-2,105-107$ & $4 \mathrm{H}-4,105-107$ & 29.76 & 32.76 & 31.26 & 1.50 \\
\hline & & T L. elongata & 15.15 & $4 \mathrm{H}-4,105-107$ & $4 \mathrm{H}-\mathrm{CC}$ & 32.76 & 37.18 & 34.97 & 2.21 \\
\hline & & B L. renzae & 16.77 & $4 \mathrm{H}-\mathrm{CC}$ & $5 \mathrm{H}-2,104-106$ & 37.18 & 39.24 & 38.21 & 1.03 \\
\hline & & B C. costata & 17.49 & $5 \mathrm{H}-2,104-106$ & $5 \mathrm{H}-4,104-106$ & 39.24 & 42.24 & 40.74 & 1.50 \\
\hline & \multirow{3}{*}{ RN3 } & B D. dentata & 17.72 & $5 \mathrm{H}-2,104-106$ & $5 \mathrm{H}-4,104-106$ & 39.24 & 42.24 & 40.74 & 1.50 \\
\hline & & B L. stauropora & 17.72 & $5 \mathrm{H}-4,104-106$ & $5 \mathrm{H}-\mathrm{CC}$ & 42.24 & 46.78 & 44.51 & 2.27 \\
\hline & & B S. wolffii & 18.57 & $5 \mathrm{H}-4,104-106$ & $5 \mathrm{H}-\mathrm{CC}$ & 42.24 & 46.78 & 44.51 & 2.27 \\
\hline & \multirow{7}{*}{ RN2 } & B D. forcipata & 18.61 & $5 \mathrm{H}-4,104-106$ & $5 \mathrm{H}-\mathrm{CC}$ & 42.24 & 46.78 & 44.51 & 2.27 \\
\hline & & T D. simplex & 18.69 & $5 \mathrm{H}-4,104-106$ & $5 \mathrm{H}-\mathrm{CC}$ & 42.24 & 46.78 & 44.51 & 2.27 \\
\hline & & T D. praeforcipata & 19.77 & $6 \mathrm{H}-4,104-106$ & $6 \mathrm{H}-\mathrm{CC}$ & 51.74 & 56.20 & 53.97 & 2.23 \\
\hline & & B D. simplex & 20.34 & 7H-2, 105-107 & $7 \mathrm{H}-4,105-107$ & 58.25 & 61.25 & 59.75 & 1.50 \\
\hline & & B S. delmontensis & 20.68 & $7 \mathrm{H}-2,105-107$ & 7H-4, 105-107 & 58.25 & 61.25 & 59.75 & 1.50 \\
\hline & & T L. pegetrum & 20.89 & 7H-4, 105-107 & $7 \mathrm{H}-\mathrm{CC}$ & 61.25 & 65.66 & 63.46 & 2.20 \\
\hline & & T T. annosa & 21.38 & $8 \mathrm{H}-4,105-107$ & $8 \mathrm{H}-\mathrm{CC}$ & 70.75 & 75.06 & 72.91 & 2.16 \\
\hline & \multirow{6}{*}{ RN1 } & B C. virginis & 21.39 & 7H-CC & $8 \mathrm{H}-2,105-107$ & 65.66 & 67.76 & 66.71 & 1.05 \\
\hline & & B L. leptetrum & 21.42 & $7 \mathrm{H}-\mathrm{CC}$ & $8 \mathrm{H}-2,105-107$ & 65.66 & 67.76 & 66.71 & 1.05 \\
\hline & & T E. mitodes & 21.95 & $9 \mathrm{H}-2,105-107$ & $9 \mathrm{H}-4,105-107$ & 77.25 & 80.25 & 78.75 & 1.50 \\
\hline & & B C. serrata & 22.04 & $9 \mathrm{H}-2,105-107$ & $9 \mathrm{H}-4,105-107$ & 77.25 & 80.25 & 78.75 & 1.50 \\
\hline & & B C. cornuta & 22.26 & $10 \mathrm{H}-2,105-107$ & $10 \mathrm{H}-4,105-107$ & 86.75 & 89.75 & 88.25 & 1.50 \\
\hline & & B C. tetrapera & 22.35 & $10 \mathrm{H}-2,105-107$ & $10 \mathrm{H}-4,105107$ & 86.75 & 89.75 & 88.25 & 1.50 \\
\hline & \multirow{10}{*}{ RP22 } & T A. gracilis & 22.62 & $10 \mathrm{H}-2,105-107$ & $10 \mathrm{H}-4,105-107$ & 86.75 & 89.75 & 88.25 & 1.50 \\
\hline & & B D. bassanii & 22.93 & $10 \mathrm{H}-2,105-107$ & $10 \mathrm{H}-4,105-107$ & 86.75 & 89.75 & 88.25 & 1.50 \\
\hline & & B E. diaphanes & 22.95 & $10 \mathrm{H}-4,105-107$ & $10 \mathrm{H}-\mathrm{CC}$ & 89.75 & 93.95 & 91.85 & 2.10 \\
\hline & & T D. cyclacantha & 22.98 & $10 \mathrm{H}-\mathrm{CC}$ & $11 \mathrm{H}-2,105-107$ & 93.95 & 96.25 & 95.10 & 1.15 \\
\hline & & T D. riedeli & 23.01 & $10 \mathrm{H}-\mathrm{CC}$ & $11 \mathrm{H}-2,105-107$ & 93.95 & 96.25 & 95.10 & 1.15 \\
\hline \multirow{18}{*}{ upper Oligocene } & & B D. cyclacantha & 23.29 & $11 \mathrm{H}-2,105-107$ & $11 \mathrm{H}-4,105-107$ & 96.25 & 99.25 & 97.75 & 1.50 \\
\hline & & T D. papilio & 23.31 & $10 \mathrm{H}-\mathrm{CC}$ & $11 \mathrm{H}-2,105-107$ & 93.95 & 96.25 & 95.10 & 1.15 \\
\hline & & $\mathrm{T} L$ L. longicornuta & 24.12 & $11 \mathrm{H}-4,105-107$ & $11 \mathrm{H}-\mathrm{CC}$ & 99.25 & 103.75 & 101.50 & 2.25 \\
\hline & & T A. octopylus & 24.38 & $13 \mathrm{H}-2,105-107$ & $13 \mathrm{H}-4,105-107$ & 114.25 & 117.25 & 115.75 & 1.50 \\
\hline & & T L. apodora & 24.50 & $13 \mathrm{H}-2,105-107$ & $13 \mathrm{H}-4,105-107$ & 114.25 & 117.25 & 115.75 & 1.50 \\
\hline & & B L. elongata & 25.05 & $13 \mathrm{H}-4,105-107$ & $13 \mathrm{H}-\mathrm{CC}$ & 117.25 & 122.55 & 119.90 & 2.65 \\
\hline & & B A. octopylus & 25.09 & & & & & & \\
\hline & & B D. praeforcipata & 25.27 & $13 \mathrm{H}-\mathrm{CC}$ & $14 \mathrm{H}-2,105-107$ & 122.55 & 124.75 & 123.65 & 1.10 \\
\hline & & B C. robusta & 25.27 & $14 \mathrm{H}-4,105-107$ & $14 \mathrm{H}-\mathrm{CC}$ & 127.75 & 131.96 & 129.86 & 2.11 \\
\hline & & B D. tubaria & 25.27 & $13 \mathrm{H}-\mathrm{CC}$ & $14 \mathrm{H}-2,105-107$ & 122.55 & 124.75 & 123.65 & 1.10 \\
\hline & & B L. longicornuta & 25.29 & $14 \mathrm{H}-4,105-107$ & $14 \mathrm{H}-\mathrm{CC}$ & 127.25 & 131.96 & 129.61 & 2.36 \\
\hline & & B D. scambos & 25.33 & & & & & & \\
\hline & RP21 & B L. apodora & 25.55 & $15 \mathrm{H}-4,105-107$ & $15 \mathrm{H}-\mathrm{CC}$ & 137.25 & 141.20 & 139.23 & 1.97 \\
\hline & $K P \angle I$ & T D. circulus & 26.17 & $16 \mathrm{H}-2,104-106$ & $16 \mathrm{H}-4,104-106$ & 143.74 & 146.74 & 145.24 & 1.50 \\
\hline & & B D. riedeli & 26.20 & $16 \mathrm{H}-2,104-106$ & $16 \mathrm{H}-4,104-106$ & 143.74 & 146.74 & 145.24 & 1.50 \\
\hline & & T E. plesiodiaphanes & 26.40 & $16 \mathrm{H}-2,104-106$ & $16 \mathrm{H}-4,104-106$ & 143.74 & 146.74 & 145.24 & 1.50 \\
\hline & & T L. angusta & 27.68 & $17 \mathrm{H}-\mathrm{CC}$ & $18 \mathrm{H}-2,105-107$ & 159.97 & 162.70 & 161.34 & 1.36 \\
\hline & & T T. setanios & 28.21 & $19 \mathrm{H}-2,105-107$ & $19 \mathrm{H}-4,105-107$ & 171.51 & 174.51 & 173.01 & 1.50 \\
\hline & & B T. annosa & 28.33 & $20 \mathrm{H}-\mathrm{CC}$ & $21 \mathrm{H}-2,105-107$ & 188.63 & 191.25 & 189.94 & 1.31 \\
\hline lower & & B D. ateuchus & & & & & & & \\
\hline & & T. triceros $>$ D. ateuchus & 28.60 & $20 \mathrm{H}-\mathrm{CC}$ & $21 \mathrm{H}-2,105-107$ & 188.63 & 191.25 & 189.94 & 1.31 \\
\hline
\end{tabular}


Table T4 (continued).

\begin{tabular}{|c|c|c|c|c|c|c|c|c|c|}
\hline \multirow[b]{2}{*}{ Geologic age } & \multirow[b]{2}{*}{ Zone } & \multirow[b]{2}{*}{ Marker species } & \multirow{2}{*}{$\begin{array}{c}\text { Age } \\
(\mathrm{Ma})\end{array}$} & \multicolumn{2}{|c|}{ Core, section, interval $(\mathrm{cm})$} & \multicolumn{4}{|c|}{ Depth CSF (m) } \\
\hline & & & & Top & Bottom & Top & Bottom & Midpoint & \pm \\
\hline \multirow{22}{*}{ lower Oligocene } & \multirow{22}{*}{ RP20 } & B E. mitodes & 29.41 & $21 \mathrm{H}-4,105-107$ & $21 \mathrm{H}-\mathrm{CC}$ & 194.25 & 198.48 & 196.37 & 2.11 \\
\hline & & B T. setanios & 29.51 & $21 \mathrm{H}-\mathrm{CC}$ & $22 \mathrm{H}-2,105-107$ & 198.48 & 200.75 & 199.62 & 1.14 \\
\hline & & B D. circulus & 29.96 & $21 \mathrm{H}-4,105-107$ & $21 \mathrm{H}-\mathrm{CC}$ & 194.25 & 198.48 & 196.37 & 2.11 \\
\hline & & T T. tuberosa & 30.13 & $22 \mathrm{H}-\mathrm{CC}$ & $23 \mathrm{H}-2,98-100$ & 206.86 & 209.38 & 208.12 & 1.26 \\
\hline & & T L. crux & 30.13 & $23 \mathrm{H}-2,98-100$ & $23 \mathrm{H}-4,98-100$ & 209.38 & 212.38 & 210.88 & 1.50 \\
\hline & & B E. plesiodiaphanes & 30.37 & $23 \mathrm{H}-4,98-100$ & $23 \mathrm{H}-\mathrm{CC}$ & 212.38 & 216.17 & 214.28 & 1.89 \\
\hline & & T L. oberhaensliae & 30.74 & $23 \mathrm{H}-\mathrm{CC}$ & $24 \mathrm{H}-2,105-107$ & 216.17 & 217.05 & 216.61 & 0.44 \\
\hline & & B D. spinosa & 30.84 & $24 \mathrm{H}-4,105-107$ & $24 \mathrm{H}-\mathrm{CC}$ & 220.05 & 224.22 & 222.14 & 2.08 \\
\hline & & T D. pseudopaplilio & 30.84 & $24 \mathrm{H}-\mathrm{CC}$ & $25 \mathrm{H}-2,105-107$ & 224.22 & 226.65 & 225.44 & 1.22 \\
\hline & & T C. gravida & 30.89 & $25 \mathrm{H}-2,105-107$ & $25 \mathrm{H}-4,105-107$ & 226.65 & 229.65 & 228.15 & 1.50 \\
\hline & & B L. crux & 31.00 & & & & & & \\
\hline & & B T. tuberosa & 31.00 & $26 \mathrm{H}-2,104-106$ & $26 \mathrm{H}-4,104-106$ & 236.14 & 239.14 & 237.64 & 1.50 \\
\hline & & B D. pseudopaplilio & 31.00 & $26 \mathrm{H}-4,104-106$ & $26 \mathrm{H}-\mathrm{CC}$ & 239.14 & 243.36 & 241.25 & 2.11 \\
\hline & & B C. gravida & 31.01 & $26 \mathrm{H}-4,104-106$ & $26 \mathrm{H}-\mathrm{CC}$ & 239.14 & 243.36 & 241.25 & 2.11 \\
\hline & & T T. triacantha & 33.34 & & & & & & \\
\hline & & $\mathrm{T}$ L. aristotelis gr. & 33.51 & $26 \mathrm{H}-\mathrm{CC}$ & $27 \mathrm{H}-\mathrm{CC}$ & 243.36 & 250.76 & 247.06 & 3.70 \\
\hline & & T C. hispida & 33.62 & $26 \mathrm{H}-\mathrm{CC}$ & $27 \mathrm{H}-\mathrm{CC}$ & 243.36 & 250.76 & 247.06 & 3.70 \\
\hline & & T C. ornatum & 33.62 & $26 \mathrm{H}-\mathrm{CC}$ & $27 \mathrm{H}-\mathrm{CC}$ & 243.36 & 250.76 & 247.06 & 3.70 \\
\hline & & T L. hadra & 33.75 & $26 \mathrm{H}-\mathrm{CC}$ & $27 \mathrm{H}-\mathrm{CC}$ & 243.36 & 250.76 & 247.06 & 3.70 \\
\hline & & T L. amphitrite & 33.75 & $26 \mathrm{H}-\mathrm{CC}$ & $27 \mathrm{H}-\mathrm{CC}$ & 243.36 & 250.76 & 247.06 & 3.70 \\
\hline & & T L. babylonis & 33.75 & $26 \mathrm{H}-\mathrm{CC}$ & $27 \mathrm{H}-\mathrm{CC}$ & 243.36 & 250.76 & 247.06 & 3.70 \\
\hline & & L. aristotelis $>$ L. angusta & 33.82 & $26 \mathrm{H}-\mathrm{CC}$ & $27 \mathrm{H}-\mathrm{CC}$ & 243.36 & 250.76 & 247.06 & 3.70 \\
\hline \multirow{11}{*}{ upper Eocene } & \multirow{8}{*}{ RP19 } & T D. copetata & 33.84 & $26 \mathrm{H}-4,104-106$ & $26 \mathrm{H}-\mathrm{CC}$ & 239.14 & 243.36 & 241.25 & 2.11 \\
\hline & & B L. angusta & 34.13 & $26 \mathrm{H}-\mathrm{CC}$ & $27 \mathrm{H}-\mathrm{CC}$ & 243.36 & 250.76 & 247.06 & 3.70 \\
\hline & & T C. bandyca & 34.62 & $28 \mathrm{H}-2,126-127$ & $28 \mathrm{H}-3,105-107$ & 255.56 & 256.85 & 256.21 & 0.65 \\
\hline & & T C. turris & 34.83 & $28 \mathrm{H}-2,126-127$ & $28 \mathrm{H}-3,105-107$ & 255.56 & 256.85 & 256.21 & 0.65 \\
\hline & & T E. fistuligerum & 34.93 & & & & & & \\
\hline & & Т T. bromia & 33.94 & $28 \mathrm{H}-2,126-127$ & $28 \mathrm{H}-3,105-107$ & 255.56 & 256.85 & 256.21 & 0.65 \\
\hline & & T T. lochites & 34.13 & $28 \mathrm{H}-2,126-127$ & $28 \mathrm{H}-3,105-107$ & 255.56 & 256.85 & 256.21 & 0.65 \\
\hline & & T C. $a z y x$ & 35.07 & $28 \mathrm{H}-2,126-127$ & $28 \mathrm{H}-3,105-107$ & 255.56 & 256.85 & 256.21 & 0.65 \\
\hline & & T T. tetracantha & 35.30 & $28 \mathrm{H}-2,126-127$ & $28 \mathrm{H}-3,105-107$ & 255.56 & 256.85 & 256.21 & 0.65 \\
\hline & RP18 & B L. hadra & 35.34 & $28 \mathrm{H}-\mathrm{CC}$ & $29 X-2,50-52$ & 262.62 & 263.85 & 263.24 & 0.62 \\
\hline & & B C. bandyca & 36.74 & $29 X-4,104-106$ & $29 \mathrm{X}-\mathrm{CC}$ & 266.45 & 272.00 & 269.23 & 2.78 \\
\hline
\end{tabular}

Note: $\mathrm{T}=$ top, $\mathrm{B}=$ bottom.

Table T5. Preservation and relative abundance of radiolarians, Hole U1334A. This table is available in an oversized format. 


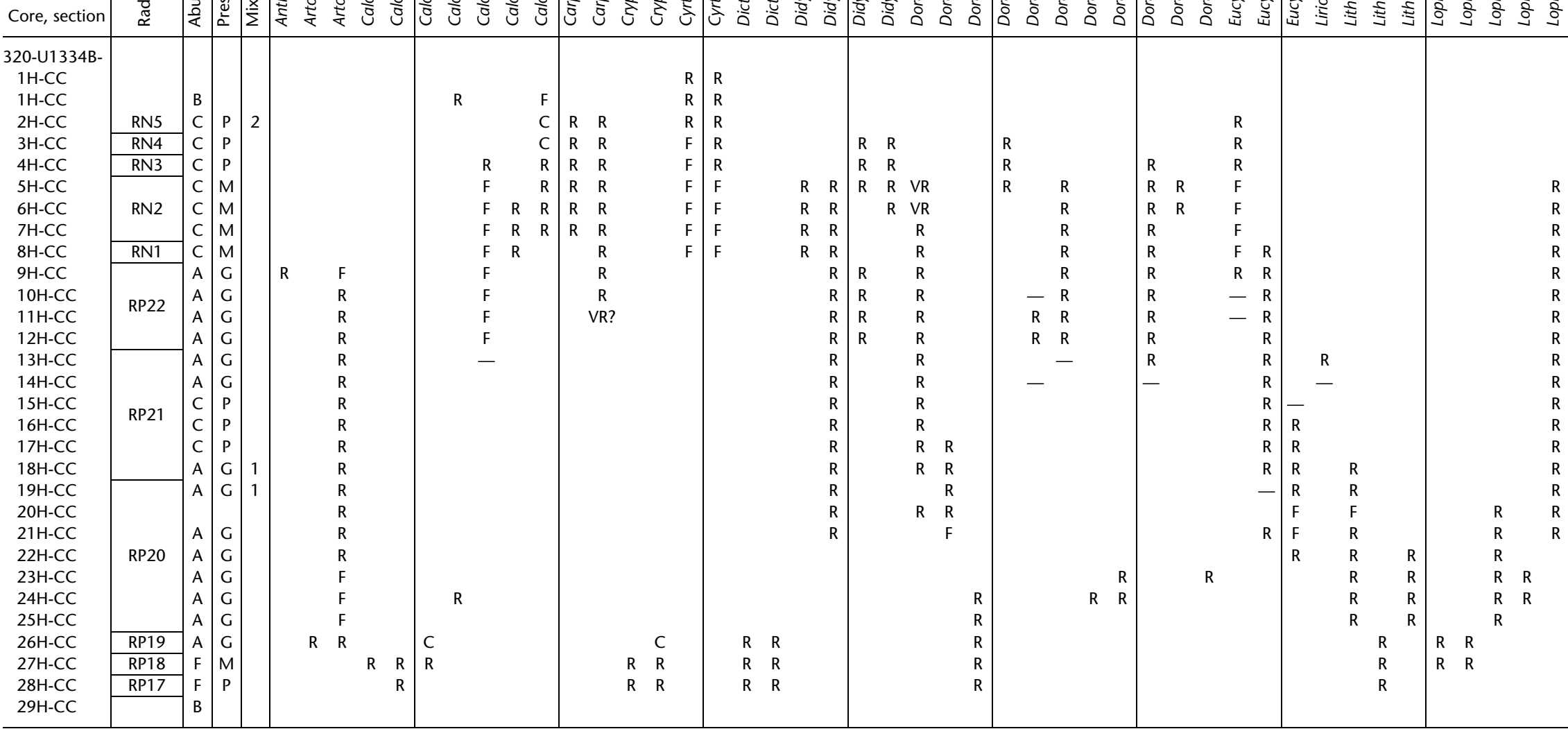

Notes: Abundance: $\mathrm{A}=$ abundant, $\mathrm{C}=$ common, $\mathrm{F}=$ frequent, $\mathrm{R}=$ rare, $\mathrm{VR}=$ very rare, $\mathrm{B}=$ barren,$-=$ undetermined. Preservation: $\mathrm{G}=$ good, $\mathrm{M}=$ moderate, $\mathrm{P}=$ poor. Mixing: blank $=$ no mixing of older specimens detected, $1=1-3$ reworked specimens detected, $2=3-10$ reworked specimens detected. 


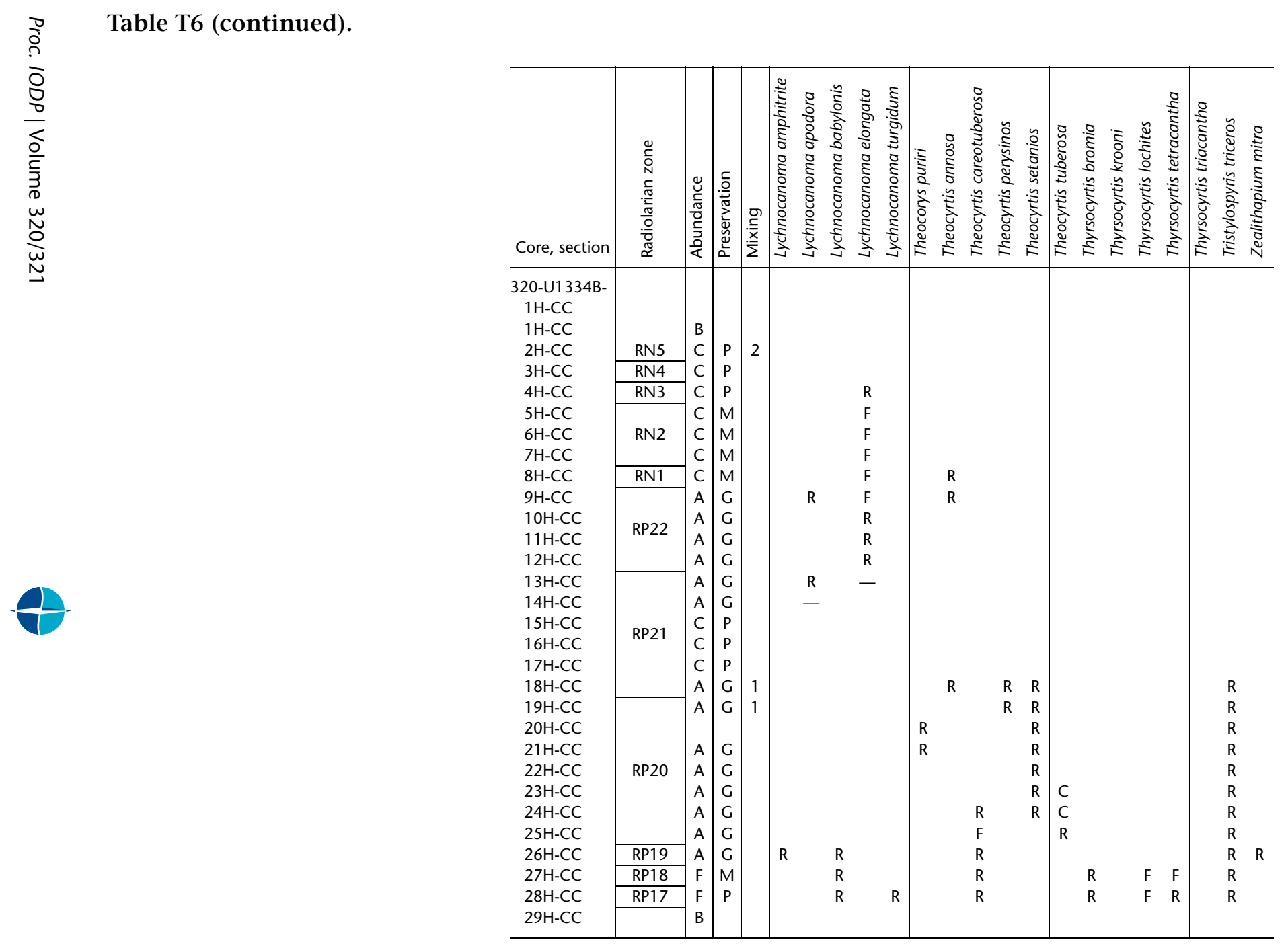




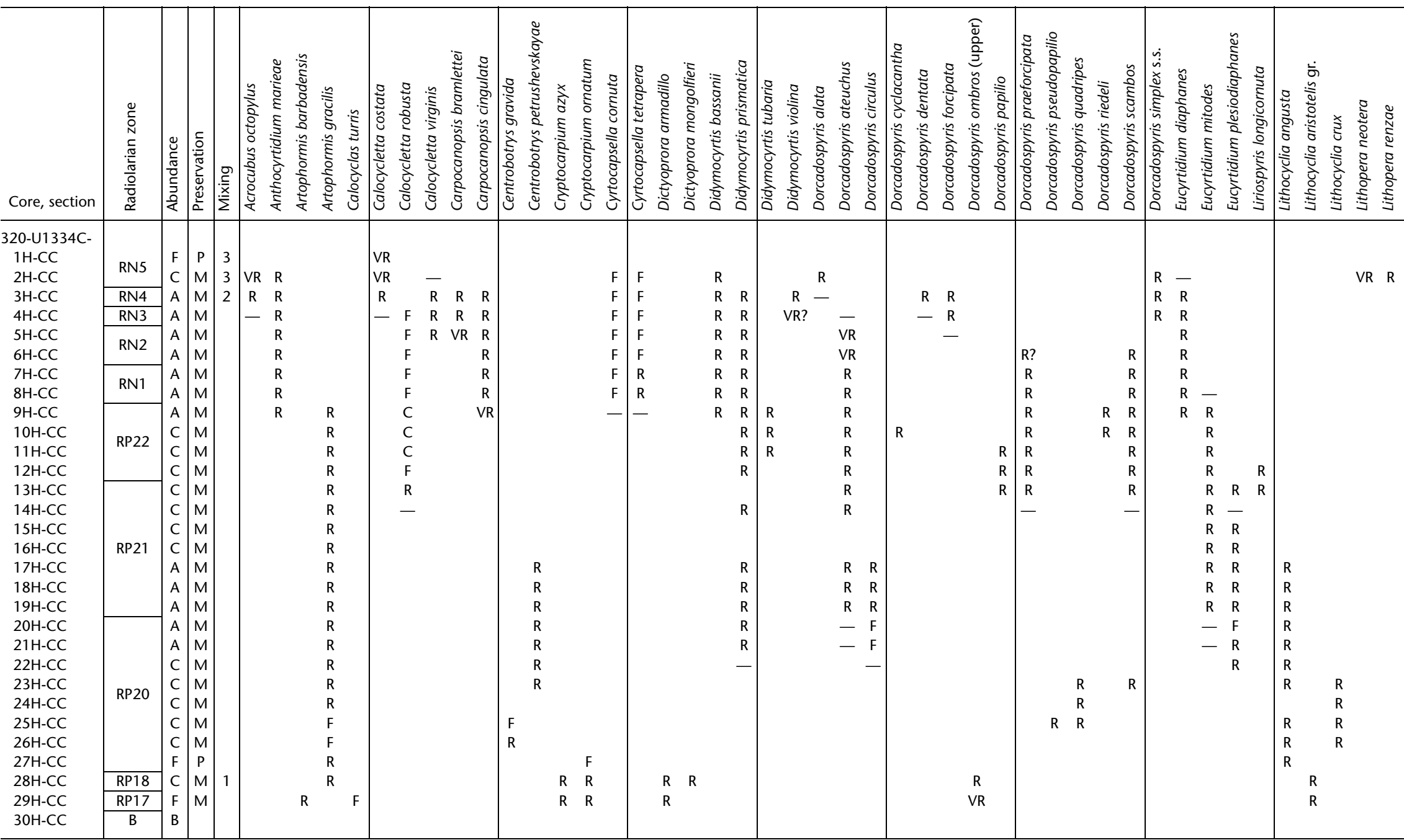

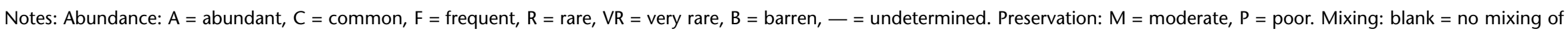
older specimens detected, $1=1-3$ reworked specimens detected, $2=3-10$ reworked specimens detected, $3=>10$ reworked specimens detected. 


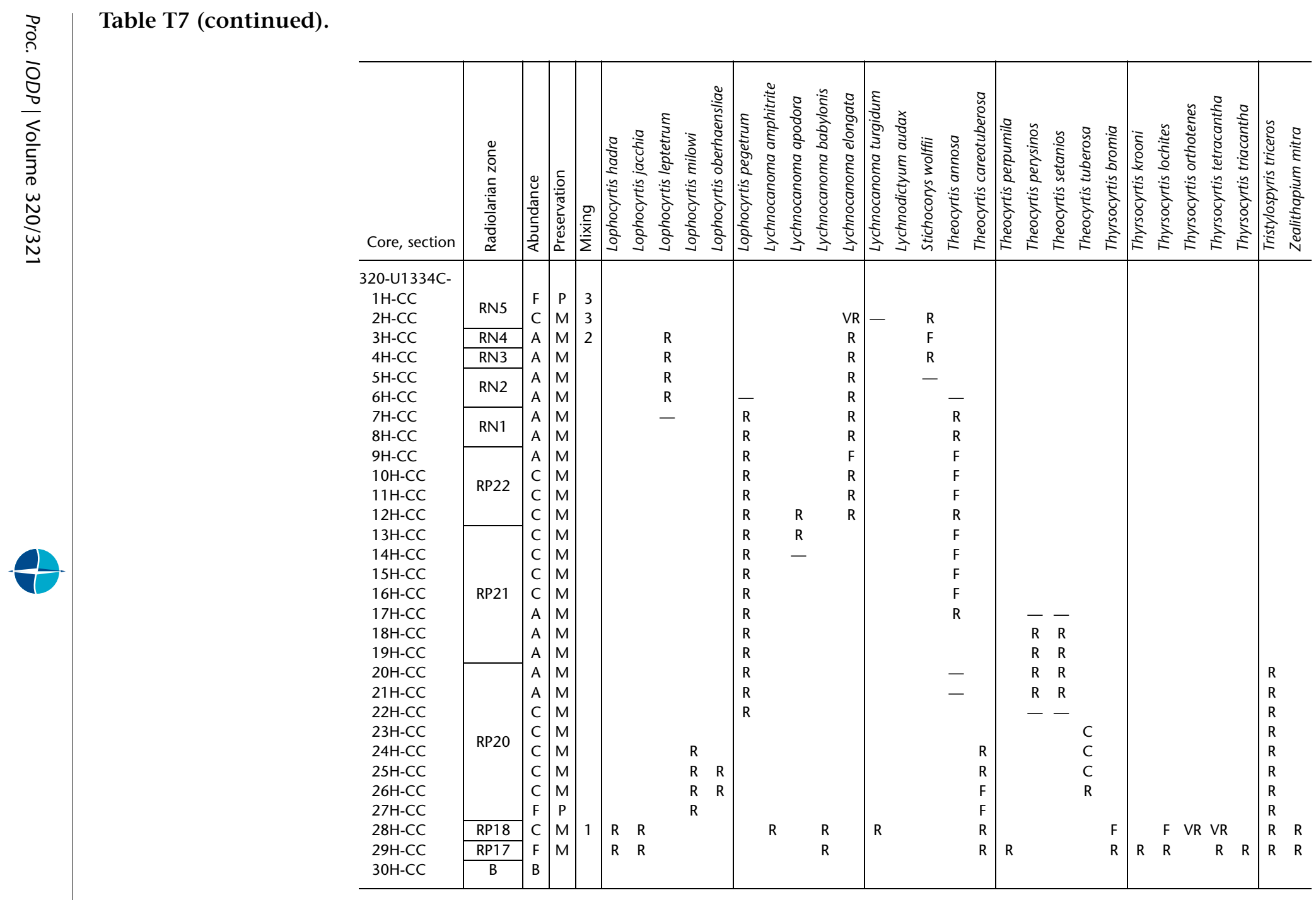


Table T8. Planktonic foraminifer datums, Site U1334. (See table note.)

\begin{tabular}{|c|c|c|c|c|c|c|c|}
\hline \multicolumn{2}{|c|}{ Core, section, interval $(\mathrm{cm})$} & \multirow[b]{2}{*}{ Marker species } & \multirow{2}{*}{$\begin{array}{l}\text { Age } \\
(\mathrm{Ma})\end{array}$} & \multicolumn{4}{|c|}{ Depth CSF $(m)$} \\
\hline Top & Bottom & & & Top & Bottom & Midpoint & \pm \\
\hline 320-U1334A- & 320-U1334A- & & & & & & \\
\hline $2 \mathrm{H}-\mathrm{CC}$ & $3 \mathrm{H}-2,38-40$ & B Globorotalia (Fonsella) fohsi robusta & 13.13 & 18.11 & 19.58 & 18.85 & 0.73 \\
\hline $4 \mathrm{H}-5,38-40$ & $5 \mathrm{H}-\mathrm{CC}$ & B Praeorbulina sicana & 16.97 & 33.58 & 46.78 & 40.18 & 6.60 \\
\hline $5 \mathrm{H}-4,39-40$ & $5 \mathrm{H}-6,39-41$ & T Paragloborotalia kugleri & 21.12 & 41.59 & 44.59 & 43.09 & 1.50 \\
\hline $5 \mathrm{H}-4,39-40$ & $5 \mathrm{H}-6,39-41$ & T Paragloborotalia pseudokugleri & 21.31 & 41.59 & 44.59 & 43.09 & 1.50 \\
\hline $8 \mathrm{H}-\mathrm{CC}$ & $9 \mathrm{H}-\mathrm{CC}$ & B Globoquadrina dehiscens & 22.44 & 75.06 & 84.74 & 79.90 & 4.84 \\
\hline $10 \mathrm{H}-2,38-40$ & $10 \mathrm{H}-5,38-40$ & B Paragloborotalia kugleri & 23.0 & 86.08 & 90.58 & 88.33 & 2.25 \\
\hline $13 \mathrm{H}-2,38-40$ & $13 \mathrm{H}-\mathrm{CC}$ & B Paragloborotalia pseudokugleri & 25.2 & 113.58 & 122.55 & 118.07 & 4.49 \\
\hline $16 \mathrm{X}-\mathrm{CC}$ & $17 X-2,10-12$ & T Paragloborotalia opima & 26.9 & 149.62 & 152.58 & 151.10 & 1.48 \\
\hline $19 \mathrm{H}-2,38-40$ & $19 \mathrm{H}-4,38-40$ & B Globigerina angulisuturalis & 29.2 & 172.18 & 175.18 & 173.68 & 1.50 \\
\hline 20X-CC & $21 X-2,38-40$ & T Subbotina angiporoides & 29.8 & 188.63 & 190.58 & 189.61 & 0.98 \\
\hline $22 X-4,38-40$ & $22 \mathrm{X}-\mathrm{CC}$ & B Paragloborotalia opima & 30.8 & 203.08 & 206.86 & 204.97 & 1.89 \\
\hline 320-U1334B- & 320-U1334B- & & & & & & \\
\hline $6 \mathrm{H}-\mathrm{CC}$ & $7 \mathrm{H}-\mathrm{CC}$ & T Paragloborotalia kugleri & 21.1 & 59.20 & 68.88 & 64.04 & 4.84 \\
\hline $6 \mathrm{H}-\mathrm{CC}$ & $7 \mathrm{H}-\mathrm{CC}$ & T Paragloborotalia pseudokugleri & 21.3 & 59.20 & 68.88 & 64.04 & 4.84 \\
\hline $9 \mathrm{H}-\mathrm{CC}$ & $10 \mathrm{H}-\mathrm{CC}$ & B Paragloborotalia kugleri & 23.0 & 87.70 & 97.22 & 92.46 & 4.76 \\
\hline $12 \mathrm{H}-\mathrm{CC}$ & $13 \mathrm{H}-\mathrm{CC}$ & B Paragloborotalia pseudokugleri & 25.2 & 116.14 & 125.68 & 120.91 & 4.77 \\
\hline $15 \mathrm{H}-\mathrm{CC}$ & $16 \mathrm{H}-\mathrm{CC}$ & T Paragloborotalia opima & 26.9 & 144.55 & 154.18 & 149.37 & 4.81 \\
\hline $18 \mathrm{H}-\mathrm{CC}$ & $19 \mathrm{H}-\mathrm{CC}$ & B Globigerina angulisuturalis & 29.2 & 173.23 & 182.52 & 177.88 & 4.65 \\
\hline $20 \mathrm{H}-\mathrm{CC}$ & $21 \mathrm{H}-\mathrm{CC}$ & T Subbotina angiporoides & 29.8 & 191.55 & 201.26 & 196.41 & 4.85 \\
\hline $21 \mathrm{H}-\mathrm{CC}$ & $22 \mathrm{H}-\mathrm{CC}$ & T Turborotalia ampliapertura & 30.3 & 201.26 & 211.10 & 206.18 & 4.92 \\
\hline $23 \mathrm{H}-\mathrm{CC}$ & $24 \mathrm{H}-\mathrm{CC}$ & B Paragloborotalia opima & 30.8 & 220.45 & 228.70 & 224.58 & 4.13 \\
\hline 320-U1334C- & 320-U1334C- & & & & & & \\
\hline $5 \mathrm{H}-\mathrm{CC}$ & $6 \mathrm{H}-\mathrm{CC}$ & T Globoquadrina binaiensis & 19.09 & 48.00 & 57.25 & 52.63 & 4.63 \\
\hline $6 \mathrm{H}-\mathrm{CC}$ & $7 \mathrm{H}-\mathrm{CC}$ & T Paragloborotalia kugleri & 21.12 & 57.25 & 65.66 & 61.46 & 4.20 \\
\hline $6 \mathrm{H}-\mathrm{CC}$ & $\mathrm{7H}-\mathrm{CC}$ & T Paragloborotalia pseudokugleri & 21.31 & 57.25 & 65.66 & 61.46 & 4.20 \\
\hline 7H-CC & $8 \mathrm{H}-\mathrm{CC}$ & B Globoquadrina dehiscens & 22.44 & 65.66 & 76.33 & 71.00 & 5.34 \\
\hline $9 \mathrm{H}-\mathrm{CC}$ & $10 \mathrm{H}-\mathrm{CC}$ & B Paragloborotalia kugleri & 23.0 & 85.79 & 95.14 & 90.47 & 4.67 \\
\hline $12 \mathrm{H}-\mathrm{CC}$ & $13 \mathrm{H}-\mathrm{CC}$ & B Paragloborotalia pseudokugleri & 25.2 & 114.25 & 123.72 & 118.99 & 4.74 \\
\hline $14 \mathrm{H}-\mathrm{CC}$ & $15 \mathrm{H}-\mathrm{CC}$ & T Paragloborotalia opima & 26.9 & 133.00 & 143.29 & 138.15 & 5.14 \\
\hline $20 \mathrm{H}-\mathrm{CC}$ & $21 \mathrm{H}-\mathrm{CC}$ & T Subbotina angiporoides & 29.8 & 189.97 & 199.92 & 194.95 & 4.97 \\
\hline $21 \mathrm{H}-\mathrm{CC}$ & $22 \mathrm{H}-\mathrm{CC}$ & T Turborotalia ampliapertura & 30.3 & 199.92 & 209.36 & 204.64 & 4.72 \\
\hline $22 \mathrm{H}-\mathrm{CC}$ & $23 \mathrm{H}-\mathrm{CC}$ & B Paragloborotalia opima & 30.8 & 209.36 & 213.56 & 211.46 & 2.10 \\
\hline
\end{tabular}

Note: $\mathrm{B}=$ bottom, $\mathrm{T}=$ top.

Table T9. Distribution of planktonic foraminifers, Site U1334. This table is available in an oversized format.

Table T10. Distribution of benthic foraminifers, Site U1334. This table is available in an oversized format. 
Table T11. Coring-disturbed intervals and gaps, Site U1334. (See table notes.)

\begin{tabular}{|c|c|c|c|}
\hline $\begin{array}{l}\text { Core, section, } \\
\text { interval }(\mathrm{cm})\end{array}$ & $\begin{array}{c}\text { Type of } \\
\text { disturbance }\end{array}$ & $\begin{array}{l}\text { Core, section, } \\
\text { interval }(\mathrm{cm})\end{array}$ & $\begin{array}{c}\text { Type of } \\
\text { disturbance }\end{array}$ \\
\hline 320-U1334A- & & $28 X-3,140-150$ & Interstitial water \\
\hline $1 \mathrm{H}-1,0-150$ & Slightly disturbed or highly bioturbated & $23 \mathrm{X}-31 \mathrm{X}$, all sections & Drilling biscuits \\
\hline $1 \mathrm{H}-5,145-150$ & Interstitial water & 320-U1334B- & \\
\hline $1 \mathrm{H}-2,145-150$ & Interstitial water & $2 \mathrm{H}-1,0-4$ & Top of core \\
\hline $1 \mathrm{H}-4,145-150$ & Interstitial water & $3 \mathrm{H}-1,0-5$ & Top of core \\
\hline $2 \mathrm{H}-2,145-150$ & Interstitial water & $3 \mathrm{H}-1,46-58$ & Soupy \\
\hline $2 \mathrm{H}-5,145-150$ & Interstitial water & $4 \mathrm{H}-1,0-35$ & Top of core \\
\hline $3 \mathrm{H}-1,0-9$ & Top of core & $5 \mathrm{H}-1,0-150$ & Top of core \\
\hline $3 \mathrm{H}-2,145-150$ & Interstitial water & $5 \mathrm{H}-2,0-43$ & Top of core \\
\hline $3 \mathrm{H}-5,145-150$ & Interstitial water & $6 \mathrm{H}-1,0-76$ & Top of core \\
\hline $4 \mathrm{H}-1,0-5$ & Top of core & $6 \mathrm{H}-3,140-150$ & Whole-round sample \\
\hline $4 \mathrm{H}-2,145-150$ & Interstitial water & $7 \mathrm{H}-1,0-74$ & Top of core \\
\hline $4 \mathrm{H}-5,145-150$ & Interstitial water & $8 \mathrm{H}-1,0-3$ & Top of core \\
\hline $5 \mathrm{H}-1,0-50$ & Top of core & $9 \mathrm{H}-1,0-32$ & Top of core \\
\hline $5 \mathrm{H}-2,145-150$ & Interstitial water & $10 \mathrm{H}-1,0-3$ & Top of core \\
\hline $5 \mathrm{H}-5,145-150$ & Interstitial water & $11 \mathrm{H}-1,0-17$ & Top of core \\
\hline $6 \mathrm{H}-2,145-150$ & Interstitial water & $12 \mathrm{H}-1,0-76$ & Top of core \\
\hline $6 \mathrm{H}-5,145-150$ & Interstitial water & $13 \mathrm{H}-1,0-63$ & Top of core \\
\hline $7 \mathrm{H}-1,0-50$ & Top of core & $15 \mathrm{H}-1,0-26$ & Top of core \\
\hline 7H-3, 140-150 & Interstitial water & $18 \mathrm{H}-1,0-24$ & Top of core \\
\hline $8 \mathrm{H}-1,0-80$ & Top of core & $19 \mathrm{H}-1,0-31$ & Top of core \\
\hline $8 \mathrm{H}-3,140-150$ & Interstitial water & $20 \mathrm{H}-1,0-14$ & Top of core \\
\hline $9 \mathrm{H}-1,0-7$ & Top of core & $21 \mathrm{H}-1,0-22$ & Top of core \\
\hline $9 \mathrm{H}-3,140-150$ & Interstitial water & $21 \mathrm{H}-1,40-44$ & Void \\
\hline $10 \mathrm{H}-1,0-75$ & Top of core & $21 \mathrm{H}-7,38-50$ & Disturbed \\
\hline $10 \mathrm{H}-3,140-150$ & Interstitial water & $22 \mathrm{H}-1,0-3$ & Top of core \\
\hline $11 \mathrm{H}-1,0-78$ & Top of core & $23 \mathrm{X}-31 \mathrm{X}$, all sections & Drilling biscuits \\
\hline $11 \mathrm{H}-3,140-150$ & $\begin{array}{l}\text { Interstitial water } \\
\text { Top of core }\end{array}$ & 320-U1334C- & \\
\hline $12 \mathrm{H}-1,0-24$ & $\begin{array}{l}\text { Top of core } \\
\text { Interstitial water }\end{array}$ & $1 \mathrm{H}-1,0-150$ & Top of core \\
\hline $12 \mathrm{H}-3,140-150$ & $\begin{array}{l}\text { Interstitial water } \\
\text { Top of core }\end{array}$ & $1 \mathrm{H}-2,0-21$ & Top of core \\
\hline $\begin{array}{l}13 \mathrm{H}-1,0-37 \\
13 \mathrm{H}-4,140-150\end{array}$ & $\begin{array}{l}\text { Top of core } \\
\text { Interstitial water }\end{array}$ & $2 \mathrm{H}-1,0-80$ & Top of core \\
\hline $14 \mathrm{H}-1,0-17$ & Top of core & $3 \mathrm{H}-1,0-81$ & Top of core \\
\hline $14 \mathrm{H}-3,140-150$ & Interstitial water & $4 \mathrm{H}-1,0-38$ & Top of core \\
\hline $15 \mathrm{H}-1,0-61$ & Top of core & $5 \mathrm{H}-1,0-45$ & Top of core \\
\hline $16 \mathrm{H}-1,0-68$ & Top of core & $6 \mathrm{H}-1,0-13$ & Top of core \\
\hline $16 \mathrm{H}-3,140-150$ & Interstitial water & 7H-1, 0-150 & Top of core \\
\hline $17 \mathrm{H}-1,0-8$ & Top of core & $7 \mathrm{H}-2,0-25$ & Top of core \\
\hline $17 \mathrm{H}-1,72-73$ & Expansion & $8 \mathrm{H}-1,0-100$ & Top of core \\
\hline $17 \mathrm{H}-3,140-150$ & Interstitial water & $8 \mathrm{H}-7,33-55$ & Top of core \\
\hline $18 \mathrm{H}-1,0-140$ & Top of core & $9 \mathrm{H}-1,0-44$ & Top of core \\
\hline $18 \mathrm{H}-3,140-150$ & Interstitial water & $10 \mathrm{H}-1,0-24$ & Top of core \\
\hline $19 \mathrm{H}-1,0-35$ & Top of core & $11 \mathrm{H}-1,0-71$ & Top of core \\
\hline $19 \mathrm{H}-3,140-150$ & Interstitial water & $12 \mathrm{H}-1,0-14$ & Top of core \\
\hline $20 \mathrm{H}-1,0-30$ & Top of core & $13 \mathrm{H}-1,0-7$ & Top of core \\
\hline $20 \mathrm{H}-3,140-150$ & Interstitial water & $14 \mathrm{H}-1,0-25$ & Top of core \\
\hline $21 \mathrm{H}-1,0-57$ & Top of core & $15 \mathrm{H}-1,0-107$ & Top of core \\
\hline $21 \mathrm{H}-3,140-150$ & Interstitial water & $16 \mathrm{H}-1,0-52$ & Top of core \\
\hline $22 \mathrm{H}-1,0-150$ & Top of core & $17 \mathrm{H}-1,0-110$ & Top of core \\
\hline $22 \mathrm{H}-2,0-62$ & Top of core & $18 \mathrm{H}-1,0-12$ & Top of core \\
\hline $22 \mathrm{H}-3,140-150$ & Interstitial water & $19 \mathrm{H}-1,0-4$ & Top of core \\
\hline $23 X-1,140-150$ & Interstitial water & $22 \mathrm{H}-1,0-3$ & Top of core \\
\hline $24 X-2,140-150$ & Interstitial water & $22 \mathrm{H}-6,100-150$ & Flow-in \\
\hline $25 X-3,140-150$ & Interstitial water & $22 \mathrm{H}-7,0-63$ & Flow-in \\
\hline $26 \mathrm{X}-3,140-150$ & Interstitial water & $23 \mathrm{X}-30 \mathrm{X}$, all sections & Drilling biscuits \\
\hline
\end{tabular}

Notes: When interval listed is $0-150 \mathrm{~cm}$, entire section is included even if true section length is $<150 \mathrm{~cm}$. Top of core $=$ myriad forms of voids, disturbance, and debris from uphole that affect top portion of most cores. For that reason, probably the top $20 \mathrm{~cm}$ or so of all cores should be avoided. 
Table T12. Paleomagnetic data from archive-half sections, Hole U1334A, at 0 mT AF demagnetization. (See table notes.)

\begin{tabular}{|c|c|c|c|c|c|c|}
\hline $\begin{array}{l}\text { Core, } \\
\text { section }\end{array}$ & $\begin{array}{l}\text { Offset } \\
(\mathrm{m})\end{array}$ & $\begin{array}{l}\text { Depth } \\
\text { CSF (m) }\end{array}$ & $\begin{array}{l}\text { Declination } \\
\left({ }^{\circ}\right)\end{array}$ & $\begin{array}{l}\text { Inclination } \\
\left({ }^{\circ}\right)\end{array}$ & $\begin{array}{l}\text { Intensity } \\
(\mathrm{A} / \mathrm{m})\end{array}$ & $\begin{array}{l}\text { Time } \\
(s)\end{array}$ \\
\hline \multicolumn{7}{|c|}{ 320-U1334A- } \\
\hline $1 \mathrm{H}-1$ & 0.10 & 0.10 & 260.9 & 2.9 & $1.268 \mathrm{E}-02$ & 3322008935.71875 \\
\hline $1 \mathrm{H}-1$ & 0.15 & 0.15 & 255.4 & 8.3 & $1.585 \mathrm{E}-02$ & 3322008941.04687 \\
\hline $1 \mathrm{H}-1$ & 0.20 & 0.20 & 257.6 & 8.4 & $1.831 \mathrm{E}-02$ & 3322008946.37500 \\
\hline $1 \mathrm{H}-1$ & 0.25 & 0.25 & 256.1 & 6.1 & $1.681 \mathrm{E}-02$ & 3322008951.70312 \\
\hline $1 \mathrm{H}-1$ & 0.30 & 0.30 & 248.4 & 9.3 & $1.592 \mathrm{E}-02$ & 3322008957.03125 \\
\hline $1 \mathrm{H}-1$ & 0.35 & 0.35 & 246.2 & 8.0 & 1.882E-02 & 3322008962.34375 \\
\hline $1 \mathrm{H}-1$ & 0.40 & 0.40 & 246.2 & 10.9 & $1.814 \mathrm{E}-02$ & 3322008967.67187 \\
\hline $1 \mathrm{H}-1$ & 0.45 & 0.45 & 243.9 & 14.1 & 1.642E-02 & 3322008973.00000 \\
\hline $1 \mathrm{H}-1$ & 0.50 & 0.50 & 244.2 & 14.6 & 1.659E-02 & 3322008978.32812 \\
\hline $1 \mathrm{H}-1$ & 0.55 & 0.55 & 247.1 & 14.8 & $1.783 \mathrm{E}-02$ & 3322008983.65625 \\
\hline $1 \mathrm{H}-1$ & 0.60 & 0.60 & 246.4 & 14.2 & $1.789 \mathrm{E}-02$ & 3322008988.98437 \\
\hline $1 \mathrm{H}-1$ & 0.65 & 0.65 & 246.4 & 14.4 & $1.511 \mathrm{E}-02$ & 3322008994.31250 \\
\hline $1 \mathrm{H}-1$ & 0.70 & 0.70 & 241.2 & 16.7 & $1.288 \mathrm{E}-02$ & 3322008999.65625 \\
\hline $1 \mathrm{H}-1$ & 0.75 & 0.75 & 237.4 & 19.8 & 6.067E-03 & 3322009004.98437 \\
\hline $1 \mathrm{H}-1$ & 0.80 & 0.80 & 237.6 & 26.0 & 4.489E-03 & 3322009010.31250 \\
\hline $1 \mathrm{H}-1$ & 0.85 & 0.85 & 256.1 & 15.0 & $5.982 \mathrm{E}-03$ & 3322009015.64062 \\
\hline $1 \mathrm{H}-1$ & 0.90 & 0.90 & 37.7 & 40.2 & $9.689 \mathrm{E}-04$ & 3322009020.95312 \\
\hline $1 \mathrm{H}-1$ & 0.95 & 0.95 & 87.0 & 10.5 & $2.106 \mathrm{E}-03$ & 3322009026.28125 \\
\hline $1 \mathrm{H}-1$ & 1.00 & 1.00 & 87.8 & 16.1 & $1.854 \mathrm{E}-03$ & 3322009031.60937 \\
\hline $1 \mathrm{H}-1$ & 1.05 & 1.05 & 236.2 & 23.9 & $2.866 \mathrm{E}-03$ & 3322009036.93750 \\
\hline $1 \mathrm{H}-1$ & 1.10 & 1.10 & 241.2 & 15.7 & $4.646 \mathrm{E}-03$ & 3322009042.26562 \\
\hline $1 \mathrm{H}-1$ & 1.15 & 1.15 & 203.1 & 2.8 & $8.103 E-03$ & 3322009047.59375 \\
\hline $1 \mathrm{H}-1$ & 1.20 & 1.20 & 236.4 & -15.2 & $2.305 \mathrm{E}-02$ & 3322009052.90625 \\
\hline $1 \mathrm{H}-1$ & 1.25 & 1.25 & 279.4 & -19.1 & $1.366 \mathrm{E}-02$ & 3322009058.23437 \\
\hline $1 \mathrm{H}-1$ & 1.30 & 1.30 & 75.3 & -19.0 & $2.285 \mathrm{E}-03$ & 3322009063.56250 \\
\hline $1 \mathrm{H}-1$ & 1.35 & 1.35 & 96.2 & -9.1 & $2.510 \mathrm{E}-03$ & 3322009068.89062 \\
\hline $1 \mathrm{H}-1$ & 1.40 & 1.40 & 84.8 & -11.7 & $1.130 \mathrm{E}-03$ & 3322009074.21875 \\
\hline $1 \mathrm{H}-2$ & 0.10 & 1.60 & 180.4 & 10.1 & $1.184 \mathrm{E}-03$ & 3322010145.17187 \\
\hline $1 \mathrm{H}-2$ & 0.15 & 1.65 & 27.0 & 15.6 & 3.677E-04 & 3322010150.50000 \\
\hline $1 \mathrm{H}-2$ & 0.20 & 1.70 & 109.2 & 5.8 & $5.426 \mathrm{E}-04$ & 3322010155.82812 \\
\hline $1 \mathrm{H}-2$ & 0.25 & 1.75 & 140.0 & -0.6 & 8.937E-04 & 3322010161.14062 \\
\hline $1 \mathrm{H}-2$ & 0.30 & 1.80 & 164.3 & 13.5 & $1.339 \mathrm{E}-03$ & 3322010166.46875 \\
\hline $1 \mathrm{H}-2$ & 0.35 & 1.85 & 224.1 & 14.5 & $6.962 \mathrm{E}-03$ & 3322010171.79687 \\
\hline $1 \mathrm{H}-2$ & 0.40 & 1.90 & 235.9 & 9.0 & 1.199E-02 & 3322010177.12500 \\
\hline $1 \mathrm{H}-2$ & 0.45 & 1.95 & 224.8 & 15.6 & $9.391 \mathrm{E}-03$ & 3322010182.45312 \\
\hline $1 \mathrm{H}-2$ & 0.50 & 2.00 & 218.1 & 15.8 & $7.869 \mathrm{E}-03$ & 3322010187.76562 \\
\hline $1 \mathrm{H}-2$ & 0.55 & 2.05 & 196.1 & 26.3 & $1.526 \mathrm{E}-03$ & 3322010193.09375 \\
\hline $1 \mathrm{H}-2$ & 0.60 & 2.10 & 231.8 & 17.9 & $1.432 \mathrm{E}-03$ & 3322010198.42187 \\
\hline $1 \mathrm{H}-2$ & 0.65 & 2.15 & 221.4 & 4.2 & $1.870 \mathrm{E}-03$ & 3322010203.75000 \\
\hline $1 \mathrm{H}-2$ & 0.70 & 2.20 & 62.7 & -15.3 & $5.316 \mathrm{E}-04$ & 3322010209.07812 \\
\hline $1 \mathrm{H}-2$ & 0.75 & 2.25 & 76.3 & -7.3 & $1.217 \mathrm{E}-03$ & 3322010214.40625 \\
\hline $1 \mathrm{H}-2$ & 0.80 & 2.30 & 156.7 & 13.4 & $1.491 \mathrm{E}-03$ & 3322010219.73437 \\
\hline $1 \mathrm{H}-2$ & 0.85 & 2.35 & 226.6 & 13.4 & $1.375 \mathrm{E}-03$ & 3322010225.06250 \\
\hline $1 \mathrm{H}-2$ & 0.90 & 2.40 & 158.9 & 10.2 & $6.641 \mathrm{E}-04$ & 3322010230.43750 \\
\hline $1 \mathrm{H}-2$ & 0.95 & 2.45 & 185.8 & -0.9 & 7.974E-04 & 3322010235.81250 \\
\hline $1 \mathrm{H}-2$ & 1.00 & 2.50 & 219.0 & 6.2 & 4.975E-04 & 3322010241.17187 \\
\hline $1 \mathrm{H}-2$ & 1.05 & 2.55 & 47.4 & 19.9 & $1.805 \mathrm{E}-04$ & 3322010246.50000 \\
\hline $1 \mathrm{H}-2$ & 1.10 & 2.60 & 217.0 & 20.2 & $6.357 \mathrm{E}-04$ & 3322010251.81250 \\
\hline $1 \mathrm{H}-2$ & 1.15 & 2.65 & 199.7 & 34.9 & $1.630 \mathrm{E}-03$ & 3322010257.34375 \\
\hline $1 \mathrm{H}-2$ & 1.20 & 2.70 & 216.8 & 25.2 & $4.188 \mathrm{E}-03$ & 3322010262.71875 \\
\hline $1 \mathrm{H}-2$ & 1.25 & 2.75 & 220.2 & 15.4 & 7.667E-03 & 3322010268.04687 \\
\hline $1 \mathrm{H}-2$ & 1.30 & 2.80 & 212.6 & 13.5 & $9.137 \mathrm{E}-03$ & 3322010273.37500 \\
\hline $1 \mathrm{H}-2$ & 1.35 & 2.85 & 219.4 & 12.7 & $1.321 \mathrm{E}-02$ & 3322010278.71875 \\
\hline $1 \mathrm{H}-2$ & 1.40 & 2.90 & 220.5 & 11.6 & $1.440 \mathrm{E}-02$ & 3322010284.04687 \\
\hline $1 \mathrm{H}-3$ & 0.10 & 3.10 & 224.9 & 6.0 & $1.185 \mathrm{E}-02$ & 3322011464.93750 \\
\hline $1 \mathrm{H}-3$ & 0.15 & 3.15 & 220.2 & 0.7 & $7.392 \mathrm{E}-03$ & 3322011470.25000 \\
\hline $1 \mathrm{H}-3$ & 0.20 & 3.20 & 221.2 & -2.3 & $6.201 \mathrm{E}-03$ & 3322011475.57812 \\
\hline $1 \mathrm{H}-3$ & 0.25 & 3.25 & 224.7 & 1.5 & $9.092 \mathrm{E}-03$ & 3322011480.90625 \\
\hline $1 \mathrm{H}-3$ & 0.30 & 3.30 & 223.6 & 4.9 & $1.044 \mathrm{E}-02$ & 3322011486.23437 \\
\hline $1 \mathrm{H}-3$ & 0.35 & 3.35 & 227.2 & 2.8 & $8.726 \mathrm{E}-03$ & 3322011491.56250 \\
\hline $1 \mathrm{H}-3$ & 0.40 & 3.40 & 227.0 & 0.1 & $9.358 \mathrm{E}-03$ & 3322011496.87500 \\
\hline $1 \mathrm{H}-3$ & 0.45 & 3.45 & 226.3 & 1.0 & $9.764 \mathrm{E}-03$ & 3322011502.20312 \\
\hline $1 \mathrm{H}-3$ & 0.50 & 3.50 & 224.6 & 1.8 & $6.852 \mathrm{E}-03$ & 3322011507.53125 \\
\hline
\end{tabular}

Notes: Time $=$ since 1 January 1904. Only a portion of this table appears here. The complete table is available in ASCII. 
Table T13. Paleomagnetic data from archive-half sections, Hole U1334A, at $20 \mathrm{mT}$ AF demagnetization. (See table notes.)

\begin{tabular}{|c|c|c|c|c|c|c|c|c|c|c|c|c|c|c|}
\hline \multirow{3}{*}{$\begin{array}{c}\text { Core, } \\
\text { section }\end{array}$} & \multirow{3}{*}{$\begin{array}{l}\text { Offset } \\
\text { (m) }\end{array}$} & \multirow{3}{*}{$\begin{array}{l}\text { Depth } \\
\operatorname{CSF}(m)\end{array}$} & \multirow{3}{*}{$\begin{array}{c}\text { Declination } \\
\left({ }^{\circ}\right)\end{array}$} & \multirow{3}{*}{$\begin{array}{c}\text { Inclination } \\
\left({ }^{\circ}\right)\end{array}$} & \multirow{3}{*}{$\begin{array}{l}\text { Intensity } \\
(\mathrm{A} / \mathrm{m})\end{array}$} & \multirow{3}{*}{$\begin{array}{c}\text { Time } \\
(s)\end{array}$} & \multicolumn{3}{|c|}{ Declination } & \multirow{3}{*}{$\begin{array}{l}\text { CCSF } \\
\text { offset } \\
(\mathrm{m})\end{array}$} & \multirow{2}{*}{\multicolumn{2}{|c|}{ Depth $(\mathrm{m})$}} & \multirow{2}{*}{\multicolumn{2}{|c|}{$\operatorname{VGP}\left({ }^{\circ}\right)$}} \\
\hline & & & & & & & \multirow{2}{*}{$\begin{array}{c}\text { Core mean } \\
\left(^{\circ}\right)\end{array}$} & \multicolumn{2}{|c|}{ Geographical coordinates } & & & & & \\
\hline & & & & & & & & $0^{\circ}-360^{\circ}$ & $-90^{\circ}-270^{\circ}$ & & CCSF-A & CCSF-B & Latitude & Longitude \\
\hline \multicolumn{15}{|c|}{ 320-U1334A- } \\
\hline $1 \mathrm{H}-1$ & 0.100 & 0.100 & 258.3 & 10.1 & $6.761 \mathrm{E}-03$ & 3322009362.71875 & 227.8 & 30.5 & 30.5 & 0.000 & 0.100 & 0.086 & 59.6 & 321.6 \\
\hline $1 \mathrm{H}-1$ & 0.150 & 0.150 & 252.8 & 15.9 & $7.343 \mathrm{E}-03$ & 3322009368.03125 & 227.8 & 25.0 & 25.0 & 0.000 & 0.150 & 0.129 & 65.3 & 316.0 \\
\hline $1 \mathrm{H}-1$ & 0.200 & 0.200 & 254.9 & 17.1 & $7.991 \mathrm{E}-03$ & 3322009373.35937 & 227.8 & 27.1 & 27.1 & 0.000 & 0.200 & 0.172 & 63.2 & 314.5 \\
\hline $1 \mathrm{H}-1$ & 0.250 & 0.250 & 252.9 & 16.7 & $8.058 \mathrm{E}-03$ & 3322009378.68750 & 227.8 & 25.1 & 25.1 & 0.000 & 0.250 & 0.216 & 65.2 & 315.0 \\
\hline $1 \mathrm{H}-1$ & 0.300 & 0.300 & 253.2 & 15.3 & $8.186 \mathrm{E}-03$ & 3322009384.01562 & 227.8 & 25.4 & 25.4 & 0.000 & 0.300 & 0.259 & 64.8 & 316.7 \\
\hline $1 \mathrm{H}-1$ & 0.350 & 0.350 & 249.5 & 14.2 & $8.907 \mathrm{E}-03$ & 3322009389.34375 & 227.8 & 21.7 & 21.7 & 0.000 & 0.350 & 0.302 & 68.5 & 318.7 \\
\hline $1 \mathrm{H}-1$ & 0.400 & 0.400 & 248.1 & 15.6 & $8.551 \mathrm{E}-03$ & 3322009394.65625 & 227.8 & 20.3 & 20.3 & 0.000 & 0.400 & 0.345 & 69.9 & 316.8 \\
\hline $1 \mathrm{H}-1$ & 0.450 & 0.450 & 244.2 & 21.5 & $7.775 \mathrm{E}-03$ & 3322009399.98437 & 227.8 & 16.4 & 16.4 & 0.000 & 0.450 & 0.388 & 73.5 & 305.7 \\
\hline $1 \mathrm{H}-1$ & 0.500 & 0.500 & 242.5 & 21.4 & $7.816 \mathrm{E}-03$ & 3322009405.31250 & 227.8 & 14.7 & 14.7 & 0.000 & 0.500 & 0.431 & 75.2 & 304.9 \\
\hline $1 \mathrm{H}-1$ & 0.550 & 0.550 & 245.8 & 21.0 & $8.196 \mathrm{E}-03$ & 3322009410.64062 & 227.8 & 18.0 & 18.0 & 0.000 & 0.550 & 0.474 & 72.0 & 307.5 \\
\hline $1 \mathrm{H}-1$ & 0.600 & 0.600 & 246.7 & 20.4 & $8.794 \mathrm{E}-03$ & 3322009415.96875 & 227.8 & 18.9 & 18.9 & 0.000 & 0.600 & 0.517 & 71.2 & 308.8 \\
\hline $1 \mathrm{H}-1$ & 0.650 & 0.650 & 245.5 & 19.0 & $8.161 \mathrm{E}-03$ & 3322009421.28125 & 227.8 & 17.7 & 17.7 & 0.000 & 0.650 & 0.560 & 72.4 & 310.9 \\
\hline $1 \mathrm{H}-1$ & 0.700 & 0.700 & 241.6 & 19.5 & $6.880 \mathrm{E}-03$ & 3322009426.60937 & 227.8 & 13.8 & 13.8 & 0.000 & 0.700 & 0.603 & 76.2 & 308.5 \\
\hline $1 \mathrm{H}-1$ & 0.750 & 0.750 & 220.6 & 60.5 & $1.372 \mathrm{E}-03$ & 3322009431.93750 & 227.8 & 352.8 & -7.2 & 0.000 & 0.750 & 0.647 & 55.9 & 218.4 \\
\hline $1 \mathrm{H}-1$ & 0.800 & 0.800 & 76.5 & 31.7 & $1.546 \mathrm{E}-03$ & 3322009437.26562 & 227.8 & 208.7 & 208.7 & 0.000 & 0.800 & 0.690 & -52.1 & 179.7 \\
\hline $1 \mathrm{H}-1$ & 0.850 & 0.850 & 268.1 & 69.0 & $9.427 \mathrm{E}-04$ & 3322009442.59375 & 227.8 & 40.3 & 40.3 & 0.000 & 0.850 & 0.733 & 34.8 & 256.7 \\
\hline $1 \mathrm{H}-1$ & 0.900 & 0.900 & 55.5 & -2.9 & $3.569 \mathrm{E}-03$ & 3322009447.90625 & 227.8 & 187.7 & 187.7 & 0.000 & 0.900 & 0.776 & -79.9 & 178.1 \\
\hline $1 \mathrm{H}-1$ & 0.950 & 0.950 & 63.7 & -5.3 & $5.176 \mathrm{E}-03$ & 3322009453.23437 & 227.8 & 195.9 & 195.9 & 0.000 & 0.950 & 0.819 & -73.3 & 155.8 \\
\hline $1 \mathrm{H}-1$ & 1.000 & 1.000 & 65.0 & -5.0 & $5.426 \mathrm{E}-03$ & 3322009458.56250 & 227.8 & 197.2 & 197.2 & 0.000 & 1.000 & 0.862 & -72.0 & 154.9 \\
\hline $1 \mathrm{H}-1$ & 1.050 & 1.050 & 80.8 & 2.3 & $2.239 \mathrm{E}-03$ & 3322009463.89062 & 227.8 & 213.0 & 213.0 & 0.000 & 1.050 & 0.905 & -55.9 & 152.1 \\
\hline $1 \mathrm{H}-1$ & 1.100 & 1.100 & 42.9 & 17.2 & $5.401 \mathrm{E}-04$ & 3322009469.21875 & 227.8 & 175.1 & 175.1 & 0.000 & 1.100 & 0.948 & -72.5 & 244.3 \\
\hline $1 \mathrm{H}-1$ & 1.150 & 1.150 & 239.1 & 21.9 & $8.583 \mathrm{E}-04$ & 3322009474.53125 & 227.8 & 11.3 & 11.3 & 0.000 & 1.150 & 0.991 & 78.4 & 300.3 \\
\hline $1 \mathrm{H}-1$ & 1.200 & 1.200 & 123.9 & -17.8 & $4.724 \mathrm{E}-04$ & 3322009479.85937 & 227.8 & 256.1 & 256.1 & 0.000 & 1.200 & 1.034 & -14.9 & 130.7 \\
\hline $1 \mathrm{H}-1$ & 1.250 & 1.250 & 48.6 & -14.9 & $1.801 \mathrm{E}-03$ & 3322009485.18750 & 227.8 & 180.8 & 180.8 & 0.000 & 1.250 & 1.078 & -89.1 & 166.0 \\
\hline $1 \mathrm{H}-1$ & 1.300 & 1.300 & 57.0 & -7.8 & $3.629 \mathrm{E}-03$ & 3322009490.51562 & 227.8 & 189.2 & 189.2 & 0.000 & 1.300 & 1.121 & -80.0 & 161.5 \\
\hline $1 \mathrm{H}-1$ & 1.350 & 1.350 & 59.4 & -9.6 & $4.389 \mathrm{E}-03$ & 3322009495.82812 & 227.8 & 191.6 & 191.6 & 0.000 & 1.350 & 1.164 & -78.1 & 152.7 \\
\hline $1 \mathrm{H}-1$ & 1.400 & 1.400 & 55.1 & -11.1 & $4.200 \mathrm{E}-03$ & 3322009501.15625 & 227.8 & 187.3 & 187.3 & 0.000 & 1.400 & 1.207 & -82.4 & 155.9 \\
\hline $1 \mathrm{H}-2$ & 0.100 & 1.600 & 51.7 & -15.8 & $1.826 \mathrm{E}-03$ & 3322011005.10937 & 227.8 & 183.9 & 183.9 & 0.000 & 1.600 & 1.379 & -86.1 & 137.0 \\
\hline $1 \mathrm{H}-2$ & 0.150 & 1.650 & 37.3 & -15.2 & $2.649 \mathrm{E}-03$ & 3322011010.43750 & 227.8 & 169.5 & 169.5 & 0.000 & 1.650 & 1.422 & -79.6 & 317.3 \\
\hline $1 \mathrm{H}-2$ & 0.200 & 1.700 & 43.7 & -11.1 & $2.713 \mathrm{E}-03$ & 3322011015.75000 & 227.8 & 175.9 & 175.9 & 0.000 & 1.700 & 1.466 & -85.3 & 287.8 \\
\hline $1 \mathrm{H}-2$ & 0.250 & 1.750 & 46.3 & -10.8 & $2.293 \mathrm{E}-03$ & 3322011021.07812 & 227.8 & 178.5 & 178.5 & 0.000 & 1.750 & 1.509 & -87.1 & 258.4 \\
\hline $1 \mathrm{H}-2$ & 0.300 & 1.800 & 49.1 & -9.7 & $2.602 \mathrm{E}-03$ & 3322011026.40625 & 227.8 & 181.3 & 181.3 & 0.000 & 1.800 & 1.552 & -86.6 & 205.4 \\
\hline $1 \mathrm{H}-2$ & 0.350 & 1.850 & 49.7 & 45.4 & $8.920 \mathrm{E}-04$ & 3322011031.73437 & 227.8 & 181.9 & 181.9 & 0.000 & 1.850 & 1.595 & -55.1 & 225.1 \\
\hline $1 \mathrm{H}-2$ & 0.400 & 1.900 & 228.1 & 20.9 & $4.865 \mathrm{E}-03$ & 3322011037.06250 & 227.8 & 0.3 & 0.3 & 0.000 & 1.900 & 1.638 & 87.2 & 234.0 \\
\hline $1 \mathrm{H}-2$ & 0.450 & 1.950 & 231.3 & 19.5 & $5.515 \mathrm{E}-03$ & 3322011042.37500 & 227.8 & 3.5 & 3.5 & 0.000 & 1.950 & 1.681 & 86.0 & 287.2 \\
\hline $1 \mathrm{H}-2$ & 0.500 & 2.000 & 221.5 & 18.3 & $4.169 \mathrm{E}-03$ & 3322011047.70312 & 227.8 & 353.7 & -6.3 & 0.000 & 2.000 & 1.724 & 83.6 & 151.1 \\
\hline $1 \mathrm{H}-2$ & 0.550 & 2.050 & 56.7 & -4.7 & $2.218 \mathrm{E}-03$ & 3322011053.03125 & 227.8 & 188.9 & 188.9 & 0.000 & 2.050 & 1.767 & -79.5 & 170.1 \\
\hline $1 \mathrm{H}-2$ & 0.600 & 2.100 & 44.5 & -10.1 & $2.456 \mathrm{E}-03$ & 3322011058.35937 & 227.8 & 176.7 & 176.7 & 0.000 & 2.100 & 1.810 & -85.6 & 276.6 \\
\hline $1 \mathrm{H}-2$ & 0.650 & 2.150 & 37.1 & -13.4 & $1.700 \mathrm{E}-03$ & 3322011063.68750 & 227.8 & 169.3 & 169.3 & 0.000 & 2.150 & 1.853 & -79.3 & 312.3 \\
\hline $1 \mathrm{H}-2$ & 0.700 & 2.200 & 33.6 & -17.2 & $2.605 \mathrm{E}-03$ & 3322011069.00000 & 227.8 & 165.8 & 165.8 & 0.000 & 2.200 & 1.897 & -75.9 & 322.3 \\
\hline $1 \mathrm{H}-2$ & 0.750 & 2.250 & 36.6 & -12.0 & 3.057E-03 & 3322011074.32812 & 227.8 & 168.8 & 168.8 & 0.000 & 2.250 & 1.940 & -78.7 & 308.9 \\
\hline $1 \mathrm{H}-2$ & 0.800 & 2.300 & 35.8 & -14.5 & $2.577 \mathrm{E}-03$ & 3322011079.65625 & 227.8 & 168.0 & 168.0 & 0.000 & 2.300 & 1.983 & -78.1 & 315.8 \\
\hline $1 \mathrm{H}-2$ & 0.850 & 2.350 & 30.9 & -12.7 & $2.037 \mathrm{E}-03$ & 3322011084.98437 & 227.8 & 163.1 & 163.1 & 0.000 & 2.350 & 2.026 & -73.2 & 313.8 \\
\hline $1 \mathrm{H}-2$ & 0.900 & 2.400 & 12.8 & -7.5 & $1.884 \mathrm{E}-03$ & 3322011090.31250 & 227.8 & 145.0 & 145.0 & 0.000 & 2.400 & 2.069 & -54.9 & 313.2 \\
\hline $1 \mathrm{H}-2$ & 0.950 & 2.450 & 11.2 & -10.4 & $1.711 \mathrm{E}-03$ & 3322011095.62500 & 227.8 & 143.4 & 143.4 & 0.000 & 2.450 & 2.112 & -53.6 & 316.0 \\
\hline
\end{tabular}


Table T14. Paleomagnetic data from archive-half sections, Hole U1334B, at $0 \mathrm{mT}$ AF demagnetization. (See table notes.)

\begin{tabular}{|c|c|c|c|c|c|c|}
\hline $\begin{array}{l}\text { Core, } \\
\text { section }\end{array}$ & $\begin{array}{l}\text { Offset } \\
(\mathrm{m})\end{array}$ & $\begin{array}{l}\text { Depth } \\
\text { CSF (m) }\end{array}$ & $\begin{array}{l}\text { Declination } \\
\left({ }^{\circ}\right)\end{array}$ & $\begin{array}{c}\text { Inclination } \\
\left({ }^{(}\right)\end{array}$ & $\begin{array}{l}\text { Intensity } \\
(\mathrm{A} / \mathrm{m})\end{array}$ & $\begin{array}{l}\text { Time } \\
(s)\end{array}$ \\
\hline \multicolumn{7}{|c|}{ 320-U1334B- } \\
\hline $1 \mathrm{H}-1$ & 0.100 & 3.800 & 135.2 & 86.1 & $2.730 \mathrm{E}-02$ & 3322292723.68750 \\
\hline $1 \mathrm{H}-1$ & 0.150 & 3.850 & 39.5 & 57.2 & $1.146 \mathrm{E}-02$ & 3322292729.00000 \\
\hline $1 \mathrm{H}-1$ & 0.200 & 3.900 & 40.3 & 37.7 & 8.003E-03 & 3322292734.32812 \\
\hline $1 \mathrm{H}-1$ & 0.250 & 3.950 & 35.0 & 31.3 & $6.752 \mathrm{E}-03$ & 3322292739.65625 \\
\hline $1 \mathrm{H}-1$ & 0.300 & 4.000 & 35.9 & 40.0 & $5.054 \mathrm{E}-03$ & 3322292744.98437 \\
\hline $1 \mathrm{H}-1$ & 0.350 & 4.050 & 34.2 & 40.2 & $5.226 \mathrm{E}-03$ & 3322292750.31250 \\
\hline $1 \mathrm{H}-1$ & 0.400 & 4.100 & 31.2 & 38.6 & $5.560 \mathrm{E}-03$ & 3322292755.62500 \\
\hline $1 \mathrm{H}-1$ & 0.450 & 4.150 & 24.0 & 27.2 & $8.194 \mathrm{E}-03$ & 3322292760.95312 \\
\hline $1 \mathrm{H}-1$ & 0.500 & 4.200 & 27.7 & 26.0 & $9.116 \mathrm{E}-03$ & 3322292766.28125 \\
\hline $1 \mathrm{H}-1$ & 0.550 & 4.250 & 27.4 & 22.5 & $9.220 \mathrm{E}-03$ & 3322292771.60937 \\
\hline $1 \mathrm{H}-1$ & 0.600 & 4.300 & 25.0 & 20.0 & $8.512 \mathrm{E}-03$ & 3322292776.93750 \\
\hline $1 \mathrm{H}-1$ & 0.650 & 4.350 & 22.1 & 22.1 & $8.135 \mathrm{E}-03$ & 3322292782.25000 \\
\hline $1 \mathrm{H}-1$ & 0.700 & 4.400 & 23.5 & 21.2 & $8.624 \mathrm{E}-03$ & 3322292787.57812 \\
\hline $1 \mathrm{H}-1$ & 0.750 & 4.450 & 24.0 & 20.1 & 8.795E-03 & 3322292792.90625 \\
\hline $1 \mathrm{H}-1$ & 0.800 & 4.500 & 24.0 & 19.0 & $8.774 \mathrm{E}-03$ & 3322292798.23437 \\
\hline $1 \mathrm{H}-1$ & 0.850 & 4.550 & 22.5 & 19.3 & $8.225 \mathrm{E}-03$ & 3322292803.56250 \\
\hline $1 \mathrm{H}-1$ & 0.900 & 4.600 & 26.9 & 18.5 & $5.718 \mathrm{E}-03$ & 3322292808.87500 \\
\hline $1 \mathrm{H}-1$ & 0.950 & 4.650 & 15.5 & 13.3 & $5.616 \mathrm{E}-03$ & 3322292814.20312 \\
\hline $1 \mathrm{H}-1$ & 1.000 & 4.700 & 15.1 & 19.0 & $7.265 \mathrm{E}-03$ & 3322292819.53125 \\
\hline $1 \mathrm{H}-1$ & 1.050 & 4.750 & 22.5 & 24.6 & $5.829 \mathrm{E}-03$ & 3322292824.85937 \\
\hline $1 \mathrm{H}-1$ & 1.100 & 4.800 & 38.4 & 42.5 & $3.571 \mathrm{E}-03$ & 3322292830.18750 \\
\hline $1 \mathrm{H}-1$ & 1.150 & 4.850 & 32.6 & 41.6 & $3.527 \mathrm{E}-03$ & 3322292835.50000 \\
\hline $1 \mathrm{H}-1$ & 1.200 & 4.900 & 35.3 & 42.8 & $3.430 \mathrm{E}-03$ & 3322292840.82812 \\
\hline $1 \mathrm{H}-1$ & 1.250 & 4.950 & 34.2 & 37.4 & $3.734 \mathrm{E}-03$ & 3322292846.15625 \\
\hline $1 \mathrm{H}-1$ & 1.300 & 5.000 & 25.2 & 28.1 & $4.813 \mathrm{E}-03$ & 3322292851.48437 \\
\hline $1 \mathrm{H}-1$ & 1.350 & 5.050 & 22.9 & 25.0 & $5.589 \mathrm{E}-03$ & 3322292856.79687 \\
\hline $1 \mathrm{H}-1$ & 1.400 & 5.100 & 25.4 & 24.8 & $5.847 \mathrm{E}-03$ & 3322292862.12500 \\
\hline $1 \mathrm{H}-2$ & 0.100 & 5.300 & 30.6 & 52.9 & $2.785 \mathrm{E}-03$ & 3322294509.65625 \\
\hline $1 \mathrm{H}-2$ & 0.150 & 5.350 & 35.2 & 48.9 & $2.460 \mathrm{E}-03$ & 3322294514.96875 \\
\hline $1 \mathrm{H}-2$ & 0.200 & 5.400 & 35.6 & 47.0 & $2.689 \mathrm{E}-03$ & 3322294520.29687 \\
\hline $1 \mathrm{H}-2$ & 0.250 & 5.450 & 44.8 & 58.6 & $2.425 \mathrm{E}-03$ & 3322294525.62500 \\
\hline $1 \mathrm{H}-2$ & 0.300 & 5.500 & 32.3 & 60.6 & $2.518 \mathrm{E}-03$ & 3322294530.93750 \\
\hline $1 \mathrm{H}-2$ & 0.350 & 5.550 & 25.8 & 56.7 & $2.404 \mathrm{E}-03$ & 3322294536.26562 \\
\hline $1 \mathrm{H}-2$ & 0.400 & 5.600 & 23.1 & 26.1 & $2.774 \mathrm{E}-03$ & 3322294541.59375 \\
\hline $1 \mathrm{H}-2$ & 0.450 & 5.650 & 27.0 & 21.7 & $3.588 \mathrm{E}-03$ & 3322294546.92187 \\
\hline $1 \mathrm{H}-2$ & 0.500 & 5.700 & 21.6 & 28.0 & $3.049 \mathrm{E}-03$ & 3322294552.25000 \\
\hline $1 \mathrm{H}-2$ & 0.550 & 5.750 & 333.2 & 67.9 & $1.495 \mathrm{E}-03$ & 3322294557.57812 \\
\hline $1 \mathrm{H}-2$ & 0.600 & 5.800 & 227.5 & 72.7 & $1.317 \mathrm{E}-03$ & 3322294562.89062 \\
\hline $1 \mathrm{H}-2$ & 0.650 & 5.850 & 259.5 & 79.3 & $1.005 \mathrm{E}-03$ & 3322294568.21875 \\
\hline $1 \mathrm{H}-2$ & 0.700 & 5.900 & 120.1 & 50.4 & $5.614 \mathrm{E}-04$ & 3322294573.54687 \\
\hline $1 \mathrm{H}-2$ & 0.750 & 5.950 & 196.1 & 11.4 & $1.473 \mathrm{E}-03$ & 3322294578.87500 \\
\hline $1 \mathrm{H}-2$ & 0.800 & 6.000 & 5.0 & 37.3 & $1.583 \mathrm{E}-03$ & 3322294584.20312 \\
\hline $1 \mathrm{H}-2$ & 0.850 & 6.050 & 20.4 & 20.4 & $3.471 \mathrm{E}-03$ & 3322294589.51562 \\
\hline $1 \mathrm{H}-2$ & 0.900 & 6.100 & 17.7 & 16.9 & $4.213 \mathrm{E}-03$ & 3322294594.84375 \\
\hline $1 \mathrm{H}-2$ & 0.950 & 6.150 & 32.8 & 17.2 & $4.003 \mathrm{E}-03$ & 3322294600.17187 \\
\hline $1 \mathrm{H}-2$ & 1.000 & 6.200 & 25.1 & 20.8 & $4.243 \mathrm{E}-03$ & 3322294605.50000 \\
\hline $1 \mathrm{H}-2$ & 1.050 & 6.250 & 18.3 & 25.4 & $4.800 \mathrm{E}-03$ & 3322294610.82812 \\
\hline $1 \mathrm{H}-2$ & 1.100 & 6.300 & 23.7 & 22.6 & $5.608 \mathrm{E}-03$ & 3322294616.14062 \\
\hline $1 \mathrm{H}-2$ & 1.150 & 6.350 & 22.4 & 16.9 & $7.345 \mathrm{E}-03$ & 3322294621.46875 \\
\hline $1 \mathrm{H}-2$ & 1.200 & 6.400 & 20.8 & 18.1 & $7.481 \mathrm{E}-03$ & 3322294626.79687 \\
\hline $1 \mathrm{H}-2$ & 1.250 & 6.450 & 20.3 & 20.4 & $7.591 \mathrm{E}-03$ & 3322294632.12500 \\
\hline $1 \mathrm{H}-2$ & 1.300 & 6.500 & 17.8 & 18.2 & $8.302 \mathrm{E}-03$ & 3322294637.45312 \\
\hline $1 \mathrm{H}-2$ & 1.350 & 6.550 & 18.3 & 18.7 & $8.183 \mathrm{E}-03$ & 3322294642.78125 \\
\hline $1 \mathrm{H}-2$ & 1.400 & 6.600 & 18.4 & 15.8 & $9.200 \mathrm{E}-03$ & 3322294648.09375 \\
\hline $1 \mathrm{H}-3$ & 0.100 & 6.800 & 25.8 & 17.6 & $8.699 \mathrm{E}-03$ & 3322295318.12500 \\
\hline $1 \mathrm{H}-3$ & 0.150 & 6.850 & 25.6 & 18.0 & $9.581 \mathrm{E}-03$ & 3322295323.45312 \\
\hline $1 \mathrm{H}-3$ & 0.200 & 6.900 & 26.8 & 18.7 & $9.863 \mathrm{E}-03$ & 3322295328.78125 \\
\hline $1 \mathrm{H}-3$ & 0.250 & 6.950 & 26.8 & 16.3 & $1.058 \mathrm{E}-02$ & 3322295334.10937 \\
\hline $1 \mathrm{H}-3$ & 0.300 & 7.000 & 26.8 & 15.2 & $1.074 \mathrm{E}-02$ & 3322295339.43750 \\
\hline $1 \mathrm{H}-3$ & 0.350 & 7.050 & 26.6 & 15.1 & $1.041 \mathrm{E}-02$ & 3322295344.75000 \\
\hline $1 \mathrm{H}-3$ & 0.400 & 7.100 & 25.2 & 20.5 & $7.832 \mathrm{E}-03$ & 3322295350.07812 \\
\hline $1 \mathrm{H}-3$ & 0.450 & 7.150 & 27.5 & 25.0 & $4.984 \mathrm{E}-03$ & 3322295355.40625 \\
\hline
\end{tabular}

Notes: Time $=$ since 1 January 1904. Only a portion of this table appears here. The complete table is available in ASCII. 
Table T15. Paleomagnetic data from archive-half sections, Hole U1334B, at $20 \mathrm{mT}$ AF demagnetization. (See table notes.)

\begin{tabular}{|c|c|c|c|c|c|c|c|c|c|c|c|c|c|c|}
\hline \multirow{3}{*}{$\begin{array}{c}\text { Core, } \\
\text { section }\end{array}$} & \multirow{3}{*}{$\begin{array}{l}\text { Offset } \\
(\mathrm{m})\end{array}$} & \multirow{3}{*}{$\begin{array}{c}\text { Depth } \\
\text { CSF (m) }\end{array}$} & \multirow{3}{*}{$\begin{array}{l}\text { Declination } \\
\left({ }^{\circ}\right)\end{array}$} & \multirow{3}{*}{$\begin{array}{l}\text { Inclination } \\
\left({ }^{\circ}\right)\end{array}$} & \multirow{3}{*}{$\begin{array}{c}\text { Intensity } \\
(\mathrm{A} / \mathrm{m})\end{array}$} & \multirow{3}{*}{$\begin{array}{c}\text { Time } \\
(s)\end{array}$} & \multicolumn{3}{|c|}{ Declination } & \multirow{3}{*}{$\begin{array}{l}\text { CCSF } \\
\text { offset } \\
\text { (m) }\end{array}$} & \multirow{2}{*}{\multicolumn{2}{|c|}{ Depth $(\mathrm{m})$}} & \multirow{2}{*}{\multicolumn{2}{|c|}{$\operatorname{VGP}\left({ }^{\circ}\right)$}} \\
\hline & & & & & & & \multirow{2}{*}{$\begin{array}{c}\text { Core mean } \\
\left({ }^{\circ}\right)\end{array}$} & \multicolumn{2}{|c|}{ Geographical coordinates } & & & & & \\
\hline & & & & & & & & $0^{\circ}-360^{\circ}$ & $-90^{\circ}-270^{\circ}$ & & CCSF-A & CCSF-B & Latitude & Longitude \\
\hline \multicolumn{15}{|c|}{ 320-U1334B- } \\
\hline $1 \mathrm{H}-1$ & 0.100 & 3.800 & 212.6 & 38.3 & $3.388 \mathrm{E}-03$ & 3322294098.31250 & 23.8 & 188.8 & 188.8 & 4.000 & 7.800 & 6.724 & -59.2 & 211.9 \\
\hline $1 \mathrm{H}-1$ & 0.150 & 3.850 & 232.4 & 58.1 & $1.446 \mathrm{E}-03$ & 3322294103.64062 & 23.8 & 208.6 & 208.6 & 4.000 & 7.850 & 6.767 & -36.2 & 200.5 \\
\hline $1 \mathrm{H}-1$ & 0.200 & 3.900 & 44.9 & 51.6 & $1.235 \mathrm{E}-03$ & 3322294108.95312 & 23.8 & 21.1 & 21.1 & 4.000 & 7.900 & 6.810 & 58.8 & 264.1 \\
\hline $1 \mathrm{H}-1$ & 0.250 & 3.950 & 42.0 & 40.9 & $1.127 \mathrm{E}-03$ & 3322294114.28125 & 23.8 & 18.2 & 18.2 & 4.000 & 7.950 & 6.853 & 66.7 & 274.5 \\
\hline $1 \mathrm{H}-1$ & 0.300 & 4.000 & 187.1 & 78.5 & $8.713 \mathrm{E}-04$ & 3322294119.60937 & 23.8 & 163.3 & 163.3 & 4.000 & 8.000 & 6.897 & -13.2 & 234.4 \\
\hline $1 \mathrm{H}-1$ & 0.350 & 4.050 & 197.9 & 59.5 & $1.136 \mathrm{E}-03$ & 3322294124.93750 & 23.8 & 174.1 & 174.1 & 4.000 & 8.050 & 6.940 & -41.4 & 234.0 \\
\hline $1 \mathrm{H}-1$ & 0.400 & 4.100 & 178.6 & 84.5 & $1.253 \mathrm{E}-03$ & 3322294130.26562 & 23.8 & 154.8 & 154.8 & 4.000 & 8.100 & 6.983 & -1.9 & 232.7 \\
\hline $1 \mathrm{H}-1$ & 0.450 & 4.150 & 17.6 & 44.2 & $1.785 \mathrm{E}-03$ & 3322294135.59375 & 23.8 & 353.8 & -6.2 & 4.000 & 8.150 & 7.026 & 71.1 & 210.6 \\
\hline $1 \mathrm{H}-1$ & 0.500 & 4.200 & 25.9 & 30.3 & $3.069 \mathrm{E}-03$ & 3322294140.90625 & 23.8 & 2.1 & 2.1 & 4.000 & 8.200 & 7.069 & 81.5 & 241.7 \\
\hline $1 \mathrm{H}-1$ & 0.550 & 4.250 & 26.7 & 34.6 & $2.745 \mathrm{E}-03$ & 3322294146.23437 & 23.8 & 2.9 & 2.9 & 4.000 & 8.250 & 7.112 & 78.6 & 242.1 \\
\hline $1 \mathrm{H}-1$ & 0.600 & 4.300 & 25.4 & 31.2 & $2.568 \mathrm{E}-03$ & 3322294151.56250 & 23.8 & 1.6 & 1.6 & 4.000 & 8.300 & 7.155 & 81.0 & 237.9 \\
\hline $1 \mathrm{H}-1$ & 0.650 & 4.350 & 21.2 & 31.6 & $2.371 \mathrm{E}-03$ & 3322294156.89062 & 23.8 & 357.4 & -2.6 & 4.000 & 8.350 & 7.198 & 80.6 & 212.7 \\
\hline $1 \mathrm{H}-1$ & 0.700 & 4.400 & 22.3 & 28.9 & $2.565 \mathrm{E}-03$ & 3322294162.21875 & 23.8 & 358.5 & -1.5 & 4.000 & 8.400 & 7.241 & 82.4 & 217.0 \\
\hline $1 \mathrm{H}-1$ & 0.750 & 4.450 & 20.7 & 25.3 & $2.716 \mathrm{E}-03$ & 3322294167.54687 & 23.8 & 356.9 & -3.1 & 4.000 & 8.450 & 7.284 & 83.9 & 198.4 \\
\hline $1 \mathrm{H}-1$ & 0.800 & 4.500 & 21.1 & 23.0 & $2.742 \mathrm{E}-03$ & 3322294172.85937 & 23.8 & 357.3 & -2.7 & 4.000 & 8.500 & 7.328 & 85.2 & 194.5 \\
\hline $1 \mathrm{H}-1$ & 0.850 & 4.550 & 21.3 & 23.3 & $2.378 \mathrm{E}-03$ & 3322294178.18750 & 23.8 & 357.5 & -2.5 & 4.000 & 8.550 & 7.371 & 85.2 & 197.6 \\
\hline $1 \mathrm{H}-1$ & 0.900 & 4.600 & 63.3 & 10.1 & $9.396 \mathrm{E}-04$ & 3322294183.51562 & 23.8 & 39.5 & 39.5 & 4.000 & 8.600 & 7.414 & 50.7 & 319.8 \\
\hline $1 \mathrm{H}-1$ & 0.950 & 4.650 & 336.7 & -21.8 & $8.475 \mathrm{E}-04$ & 3322294188.82812 & 23.8 & 312.9 & -47.1 & 4.000 & 8.650 & 7.457 & 39.3 & 116.2 \\
\hline $1 \mathrm{H}-1$ & 1.000 & 4.700 & 358.1 & 14.3 & $1.863 \mathrm{E}-03$ & 3322294194.15625 & 23.8 & 334.3 & -25.7 & 4.000 & 8.700 & 7.500 & 64.5 & 138.1 \\
\hline $1 \mathrm{H}-1$ & 1.050 & 4.750 & 21.1 & 55.2 & 8.019E-04 & 3322294199.48437 & 23.8 & 357.3 & -2.7 & 4.000 & 8.750 & 7.543 & 62.2 & 223.3 \\
\hline $1 \mathrm{H}-1$ & 1.100 & 4.800 & 189.7 & 24.5 & $1.387 \mathrm{E}-03$ & 3322294204.81250 & 23.8 & 165.9 & 165.9 & 4.000 & 8.800 & 7.586 & -64.9 & 262.1 \\
\hline $1 \mathrm{H}-1$ & 1.150 & 4.850 & 196.6 & 27.4 & $1.136 \mathrm{E}-03$ & 3322294210.12500 & 23.8 & 172.8 & 172.8 & 4.000 & 8.850 & 7.629 & -66.4 & 245.6 \\
\hline $1 \mathrm{H}-1$ & 1.200 & 4.900 & 192.2 & 30.2 & $1.044 \mathrm{E}-03$ & 3322294215.45312 & 23.8 & 168.4 & 168.4 & 4.000 & 8.900 & 7.672 & -63.2 & 253.4 \\
\hline $1 \mathrm{H}-1$ & 1.250 & 4.950 & 188.5 & 45.2 & 7.963E-04 & 3322294220.78125 & 23.8 & 164.7 & 164.7 & 4.000 & 8.950 & 7.716 & -52.2 & 250.7 \\
\hline $1 \mathrm{H}-1$ & 1.300 & 5.000 & 186.3 & 65.2 & $7.143 \mathrm{E}-04$ & 3322294226.10937 & 23.8 & 162.5 & 162.5 & 4.000 & 9.000 & 7.759 & -32.6 & 242.1 \\
\hline $1 \mathrm{H}-1$ & 1.350 & 5.050 & 19.3 & 68.9 & $8.078 \mathrm{E}-04$ & 3322294231.43750 & 23.8 & 355.5 & -4.5 & 4.000 & 9.050 & 7.802 & 45.5 & 224.1 \\
\hline $1 \mathrm{H}-1$ & 1.400 & 5.100 & 39.0 & 65.0 & $9.995 \mathrm{E}-04$ & 3322294236.75000 & 23.8 & 15.2 & 15.2 & 4.000 & 9.100 & 7.845 & 48.9 & 243.8 \\
\hline $1 \mathrm{H}-2$ & 0.100 & 5.300 & 198.0 & 15.2 & $2.371 \mathrm{E}-03$ & 3322294926.01562 & 23.8 & 174.2 & 174.2 & 4.000 & 9.300 & 8.017 & -73.2 & 248.3 \\
\hline $1 \mathrm{H}-2$ & 0.150 & 5.350 & 195.7 & 11.4 & $2.510 \mathrm{E}-03$ & 3322294931.32812 & 23.8 & 171.9 & 171.9 & 4.000 & 9.350 & 8.060 & -74.1 & 258.7 \\
\hline $1 \mathrm{H}-2$ & 0.200 & 5.400 & 192.9 & 9.9 & $2.381 \mathrm{E}-03$ & 3322294936.65625 & 23.8 & 169.1 & 169.1 & 4.000 & 9.400 & 8.103 & -73.1 & 268.3 \\
\hline $1 \mathrm{H}-2$ & 0.250 & 5.450 & 190.6 & 7.4 & $3.013 \mathrm{E}-03$ & 3322294941.98437 & 23.8 & 166.8 & 166.8 & 4.000 & 9.450 & 8.147 & -72.4 & 276.8 \\
\hline $1 \mathrm{H}-2$ & 0.300 & 5.500 & 192.3 & 8.8 & $2.882 \mathrm{E}-03$ & 3322294947.31250 & 23.8 & 168.5 & 168.5 & 4.000 & 9.500 & 8.190 & -73.1 & 271.1 \\
\hline $1 \mathrm{H}-2$ & 0.350 & 5.550 & 194.8 & 8.1 & $2.781 \mathrm{E}-03$ & 3322294952.62500 & 23.8 & 171.0 & 171.0 & 4.000 & 9.550 & 8.233 & -75.0 & 265.0 \\
\hline $1 \mathrm{H}-2$ & 0.400 & 5.600 & 188.4 & -1.9 & $2.393 \mathrm{E}-03$ & 3322294957.95312 & 23.8 & 164.6 & 164.6 & 4.000 & 9.600 & 8.276 & -73.1 & 294.1 \\
\hline $1 \mathrm{H}-2$ & 0.450 & 5.650 & 181.3 & -4.2 & $1.800 \mathrm{E}-03$ & 3322294963.28125 & 23.8 & 157.5 & 157.5 & 4.000 & 9.650 & 8.319 & -66.8 & 304.5 \\
\hline $1 \mathrm{H}-2$ & 0.500 & 5.700 & 181.8 & -4.2 & $2.079 \mathrm{E}-03$ & 3322294968.60937 & 23.8 & 158.0 & 158.0 & 4.000 & 9.700 & 8.362 & -67.3 & 304.1 \\
\hline $1 \mathrm{H}-2$ & 0.550 & 5.750 & 192.0 & -3.0 & $2.973 \mathrm{E}-03$ & 3322294973.93750 & 23.8 & 168.2 & 168.2 & 4.000 & 9.750 & 8.405 & -76.6 & 289.7 \\
\hline $1 \mathrm{H}-2$ & 0.600 & 5.800 & 191.8 & -1.6 & $3.858 \mathrm{E}-03$ & 3322294979.25000 & 23.8 & 168.0 & 168.0 & 4.000 & 9.800 & 8.448 & -76.0 & 287.6 \\
\hline $1 \mathrm{H}-2$ & 0.650 & 5.850 & 190.8 & -1.3 & $3.614 \mathrm{E}-03$ & 3322294984.57812 & 23.8 & 167.0 & 167.0 & 4.000 & 9.850 & 8.491 & -75.1 & 289.1 \\
\hline $1 \mathrm{H}-2$ & 0.700 & 5.900 & 190.5 & -0.9 & $3.247 \mathrm{E}-03$ & 3322294989.90625 & 23.8 & 166.7 & 166.7 & 4.000 & 9.900 & 8.534 & -74.8 & 289.0 \\
\hline $1 \mathrm{H}-2$ & 0.750 & 5.950 & 190.4 & -0.5 & 3.407E-03 & 3322294995.23437 & 23.8 & 166.6 & 166.6 & 4.000 & 9.950 & 8.578 & -74.6 & 288.5 \\
\hline $1 \mathrm{H}-2$ & 0.800 & 6.000 & 187.1 & 1.0 & $3.040 \mathrm{E}-03$ & 3322295000.56250 & 23.8 & 163.3 & 163.3 & 4.000 & 10.000 & 8.621 & -71.3 & 291.7 \\
\hline
\end{tabular}

Notes: Time $=$ since 1 January 1904 VGP = virtual geomagnetic pole. Only a portion of this table appears here. The complete table is available in ASCII. 
Table T16. Paleomagnetic data from archive-half sections, Hole U1334C, at $0 \mathrm{mT}$ AF demagnetization. (See table notes.)

\begin{tabular}{|c|c|c|c|c|c|c|}
\hline $\begin{array}{l}\text { Core, } \\
\text { section }\end{array}$ & $\begin{array}{l}\text { Offset } \\
(\mathrm{m})\end{array}$ & $\begin{array}{l}\text { Depth } \\
\operatorname{CSF}(\mathrm{m})\end{array}$ & $\begin{array}{l}\text { Declination } \\
\left({ }^{\circ}\right)\end{array}$ & $\begin{array}{c}\text { Inclination } \\
\left({ }^{\circ}\right)\end{array}$ & $\begin{array}{l}\text { Intensity } \\
(\mathrm{A} / \mathrm{m})\end{array}$ & $\begin{array}{l}\text { Time } \\
(s)\end{array}$ \\
\hline \multicolumn{7}{|c|}{ 320-U1334C- } \\
\hline $1 \mathrm{H}-2$ & 0.250 & 1.750 & 95.4 & 63.4 & $4.202 \mathrm{E}-04$ & 3322540468.07812 \\
\hline $1 \mathrm{H}-2$ & 0.300 & 1.800 & 328.2 & 3.8 & $2.277 \mathrm{E}-03$ & 3322540473.40625 \\
\hline $1 \mathrm{H}-2$ & 0.350 & 1.850 & 331.7 & 1.6 & $4.024 \mathrm{E}-03$ & 3322540478.73437 \\
\hline $1 \mathrm{H}-2$ & 0.400 & 1.900 & 320.3 & 4.5 & $4.494 \mathrm{E}-03$ & 3322540484.04687 \\
\hline $1 \mathrm{H}-2$ & 0.450 & 1.950 & 326.3 & 10.4 & $5.453 \mathrm{E}-03$ & 3322540489.37500 \\
\hline $1 \mathrm{H}-2$ & 0.500 & 2.000 & 332.3 & 15.2 & 5.017E-03 & 3322540494.70312 \\
\hline $1 \mathrm{H}-2$ & 0.550 & 2.050 & 349.1 & 31.9 & $2.358 \mathrm{E}-03$ & 3322540500.03125 \\
\hline $1 \mathrm{H}-2$ & 0.600 & 2.100 & 343.7 & 31.0 & $2.179 \mathrm{E}-03$ & 3322540505.34375 \\
\hline $1 \mathrm{H}-2$ & 0.650 & 2.150 & 337.6 & 32.0 & $2.855 \mathrm{E}-03$ & 3322540510.67187 \\
\hline $1 \mathrm{H}-2$ & 0.700 & 2.200 & 335.3 & 20.4 & $5.289 \mathrm{E}-03$ & 3322540516.00000 \\
\hline $1 \mathrm{H}-2$ & 0.750 & 2.250 & 333.9 & 14.6 & $7.151 \mathrm{E}-03$ & 3322540521.32812 \\
\hline $1 \mathrm{H}-2$ & 0.800 & 2.300 & 328.5 & 12.2 & $7.804 \mathrm{E}-03$ & 3322540526.64062 \\
\hline $1 \mathrm{H}-2$ & 0.850 & 2.350 & 328.1 & 12.2 & $8.734 \mathrm{E}-03$ & 3322540531.96875 \\
\hline $1 \mathrm{H}-2$ & 0.900 & 2.400 & 326.7 & 12.0 & $9.942 \mathrm{E}-03$ & 3322540537.29687 \\
\hline $1 \mathrm{H}-2$ & 0.950 & 2.450 & 331.9 & 13.6 & $8.526 \mathrm{E}-03$ & 3322540542.62500 \\
\hline $1 \mathrm{H}-2$ & 1.000 & 2.500 & 334.8 & 15.1 & $7.170 \mathrm{E}-03$ & 3322540547.95312 \\
\hline $1 \mathrm{H}-2$ & 1.050 & 2.550 & 329.2 & 14.7 & $6.425 \mathrm{E}-03$ & 3322540553.26562 \\
\hline $1 \mathrm{H}-2$ & 1.100 & 2.600 & 329.6 & 21.3 & $4.559 \mathrm{E}-03$ & 3322540558.59375 \\
\hline $1 \mathrm{H}-2$ & 1.150 & 2.650 & 328.8 & 35.0 & $2.842 \mathrm{E}-03$ & 3322540563.92187 \\
\hline $1 \mathrm{H}-2$ & 1.200 & 2.700 & 320.4 & 44.5 & $2.380 \mathrm{E}-03$ & 3322540569.25000 \\
\hline $1 \mathrm{H}-2$ & 1.250 & 2.750 & 319.2 & 37.9 & $3.013 \mathrm{E}-03$ & 3322540574.57812 \\
\hline $1 \mathrm{H}-2$ & 1.300 & 2.800 & 320.7 & 40.2 & $2.928 \mathrm{E}-03$ & 3322540579.90625 \\
\hline $1 \mathrm{H}-2$ & 1.350 & 2.850 & 330.5 & 43.1 & $2.661 \mathrm{E}-03$ & 3322540585.21875 \\
\hline $1 \mathrm{H}-2$ & 1.400 & 2.900 & 345.1 & 46.0 & $2.331 \mathrm{E}-03$ & 3322540590.54687 \\
\hline $1 \mathrm{H}-3$ & 0.100 & 3.100 & 20.6 & 47.7 & $2.546 \mathrm{E}-03$ & 3322541712.14062 \\
\hline $1 \mathrm{H}-3$ & 0.150 & 3.150 & 24.3 & 52.9 & $2.335 \mathrm{E}-03$ & 3322541717.46875 \\
\hline $1 \mathrm{H}-3$ & 0.200 & 3.200 & 351.5 & 45.2 & $2.931 \mathrm{E}-03$ & 3322541722.78125 \\
\hline $1 \mathrm{H}-3$ & 0.250 & 3.250 & 344.3 & 28.4 & $4.581 \mathrm{E}-03$ & 3322541728.10937 \\
\hline $1 \mathrm{H}-3$ & 0.300 & 3.300 & 348.2 & 22.9 & $6.033 \mathrm{E}-03$ & 3322541733.43750 \\
\hline $1 \mathrm{H}-3$ & 0.350 & 3.350 & 347.7 & 23.4 & $6.066 \mathrm{E}-03$ & 3322541738.76562 \\
\hline $1 \mathrm{H}-3$ & 0.400 & 3.400 & 345.6 & 24.5 & $5.998 \mathrm{E}-03$ & 3322541744.09375 \\
\hline $1 \mathrm{H}-3$ & 0.450 & 3.450 & 344.6 & 21.0 & $7.275 \mathrm{E}-03$ & 3322541749.40625 \\
\hline $1 \mathrm{H}-3$ & 0.500 & 3.500 & 348.3 & 22.1 & 7.037E-03 & 3322541754.73437 \\
\hline $1 \mathrm{H}-3$ & 0.550 & 3.550 & 354.0 & 32.5 & 4.657E-03 & 3322541760.06250 \\
\hline $1 \mathrm{H}-3$ & 0.600 & 3.600 & 350.8 & 26.6 & $5.256 \mathrm{E}-03$ & 3322541765.39062 \\
\hline $1 \mathrm{H}-3$ & 0.650 & 3.650 & 347.0 & 24.8 & $5.821 \mathrm{E}-03$ & 3322541770.71875 \\
\hline $1 \mathrm{H}-3$ & 0.700 & 3.700 & 347.4 & 32.5 & $4.733 \mathrm{E}-03$ & 3322541776.03125 \\
\hline $1 \mathrm{H}-3$ & 0.750 & 3.750 & 348.5 & 42.2 & $3.769 \mathrm{E}-03$ & 3322541781.35937 \\
\hline $1 \mathrm{H}-3$ & 0.800 & 3.800 & 349.8 & 38.8 & $3.944 \mathrm{E}-03$ & 3322541786.68750 \\
\hline $1 \mathrm{H}-3$ & 0.850 & 3.850 & 354.0 & 44.3 & $3.094 \mathrm{E}-03$ & 3322541792.01562 \\
\hline $1 \mathrm{H}-3$ & 0.900 & 3.900 & 355.1 & 40.1 & $3.420 \mathrm{E}-03$ & 3322541797.34375 \\
\hline $1 \mathrm{H}-3$ & 0.950 & 3.950 & 349.5 & 29.4 & 4.503E-03 & 3322541802.65625 \\
\hline $1 \mathrm{H}-3$ & 1.000 & 4.000 & 348.4 & 20.5 & $5.137 \mathrm{E}-03$ & 3322541807.98437 \\
\hline $1 \mathrm{H}-3$ & 1.050 & 4.050 & 350.1 & 18.5 & $5.795 \mathrm{E}-03$ & 3322541813.31250 \\
\hline $1 \mathrm{H}-3$ & 1.100 & 4.100 & 352.2 & 17.9 & $5.958 \mathrm{E}-03$ & 3322541818.64062 \\
\hline $1 \mathrm{H}-3$ & 1.150 & 4.150 & 352.9 & 19.6 & $5.881 \mathrm{E}-03$ & 3322541823.96875 \\
\hline $1 \mathrm{H}-3$ & 1.200 & 4.200 & 352.3 & 20.6 & $5.759 \mathrm{E}-03$ & 3322541829.29687 \\
\hline $1 \mathrm{H}-3$ & 1.250 & 4.250 & 357.3 & 27.6 & 4.494E-03 & 3322541834.62500 \\
\hline $1 \mathrm{H}-3$ & 1.300 & 4.300 & 0.6 & 29.7 & $4.762 \mathrm{E}-03$ & 3322541839.93750 \\
\hline $1 \mathrm{H}-3$ & 1.350 & 4.350 & 357.6 & 23.0 & $5.871 \mathrm{E}-03$ & 3322541845.26562 \\
\hline $1 \mathrm{H}-3$ & 1.400 & 4.400 & 355.2 & 17.2 & $7.639 \mathrm{E}-03$ & 3322541850.59375 \\
\hline $1 \mathrm{H}-4$ & 0.100 & 4.600 & 349.3 & 19.2 & $8.808 \mathrm{E}-03$ & 3322542789.34375 \\
\hline $1 \mathrm{H}-4$ & 0.150 & 4.650 & 350.4 & 20.6 & $7.873 \mathrm{E}-03$ & 3322542794.67187 \\
\hline $1 \mathrm{H}-4$ & 0.200 & 4.700 & 351.5 & 20.9 & $7.733 \mathrm{E}-03$ & 3322542800.00000 \\
\hline $1 \mathrm{H}-4$ & 0.250 & 4.750 & 352.9 & 21.4 & $7.869 \mathrm{E}-03$ & 3322542805.32812 \\
\hline $1 \mathrm{H}-4$ & 0.300 & 4.800 & 351.8 & 21.2 & $8.126 \mathrm{E}-03$ & 3322542810.65625 \\
\hline $1 \mathrm{H}-4$ & 0.350 & 4.850 & 353.8 & 20.7 & $8.339 \mathrm{E}-03$ & 3322542815.96875 \\
\hline $1 \mathrm{H}-4$ & 0.400 & 4.900 & 355.7 & 20.8 & $8.314 \mathrm{E}-03$ & 3322542821.29687 \\
\hline $1 \mathrm{H}-4$ & 0.450 & 4.950 & 353.5 & 21.6 & $7.974 \mathrm{E}-03$ & 3322542826.62500 \\
\hline $1 \mathrm{H}-4$ & 0.500 & 5.000 & 352.7 & 27.5 & $6.083 \mathrm{E}-03$ & 3322542831.95312 \\
\hline $1 \mathrm{H}-4$ & 0.550 & 5.050 & 355.2 & 35.8 & $4.523 \mathrm{E}-03$ & 3322542837.26562 \\
\hline $1 \mathrm{H}-4$ & 0.600 & 5.100 & 359.4 & 31.7 & $4.384 \mathrm{E}-03$ & 3322542842.59375 \\
\hline
\end{tabular}

Notes: Time $=$ since 1 January 1904. Only a portion of this table appears here. The complete table is available in ASCII. 
Table T17. Paleomagnetic data from archive-half sections, Hole U1334C, at $20 \mathrm{mT}$ AF demagnetization. (See table notes.)

\begin{tabular}{|c|c|c|c|c|c|c|c|c|c|c|c|c|c|c|}
\hline \multirow{3}{*}{$\begin{array}{c}\text { Core, } \\
\text { section }\end{array}$} & \multirow{3}{*}{$\begin{array}{l}\text { Offset } \\
(\mathrm{m})\end{array}$} & \multirow{3}{*}{$\begin{array}{l}\text { Depth } \\
\text { CSF }(m)\end{array}$} & \multirow{3}{*}{$\begin{array}{l}\text { Declination } \\
\left({ }^{\circ}\right)\end{array}$} & \multirow{3}{*}{$\begin{array}{c}\text { Inclination } \\
\left(^{\circ}\right)\end{array}$} & \multirow{3}{*}{$\begin{array}{c}\text { Intensity } \\
(\mathrm{A} / \mathrm{m})\end{array}$} & \multirow{3}{*}{$\begin{array}{c}\text { Time } \\
(\mathrm{s})\end{array}$} & \multirow{3}{*}{$\begin{array}{l}\text { Core mean } \\
\left({ }^{\circ}\right)\end{array}$} & \multicolumn{2}{|c|}{ Declination } & \multirow{3}{*}{$\begin{array}{c}\text { CCSF } \\
\text { offset } \\
\text { (m) }\end{array}$} & \multirow{2}{*}{\multicolumn{2}{|c|}{ Depth $(m)$}} & \multirow{2}{*}{\multicolumn{2}{|c|}{$\operatorname{VGP}\left({ }^{\circ}\right)$}} \\
\hline & & & & & & & & Geograph & coordinates & & & & & \\
\hline & & & & & & & & $0^{\circ}-360^{\circ}$ & $-90^{\circ}-270^{\circ}$ & & CCSF-A & CCSF-B & Latitude & Longitude \\
\hline \multicolumn{15}{|c|}{ 320-U1334C- } \\
\hline $1 \mathrm{H}-2$ & 0.225 & 1.725 & 152.4 & -32.7 & $1.954 \mathrm{E}-03$ & 3322541142.42187 & 351.60 & 160.8 & 160.8 & 3.650 & 5.375 & 4.634 & -68.9 & 347.6 \\
\hline $1 \mathrm{H}-2$ & 0.250 & 1.750 & 133.0 & -29.5 & $2.056 \mathrm{E}-03$ & 3322541147.35937 & 351.60 & 141.4 & 141.4 & 3.650 & 5.400 & 4.655 & -51.5 & 333.4 \\
\hline $1 \mathrm{H}-2$ & 0.275 & 1.775 & 138.5 & -32.1 & $1.644 \mathrm{E}-03$ & 3322541152.28125 & 351.60 & 146.9 & 146.9 & 3.650 & 5.425 & 4.677 & -56.4 & 337.6 \\
\hline $1 \mathrm{H}-2$ & 0.300 & 1.800 & 135.2 & -43.2 & $1.143 \mathrm{E}-03$ & 3322541157.21875 & 351.60 & 143.6 & 143.6 & 3.650 & 5.450 & 4.698 & -51.3 & 348.8 \\
\hline $1 \mathrm{H}-2$ & 0.325 & 1.825 & 305.6 & -66.8 & $8.219 \mathrm{E}-04$ & 3322541162.15625 & 351.60 & 314.0 & -46.0 & 3.650 & 5.475 & 4.720 & 20.0 & 77.9 \\
\hline $1 \mathrm{H}-2$ & 0.350 & 1.850 & 345.7 & -34.9 & $1.353 \mathrm{E}-03$ & 3322541167.07812 & 351.60 & 354.1 & -5.9 & 3.650 & 5.500 & 4.741 & 62.2 & 60.0 \\
\hline $1 \mathrm{H}-2$ & 0.375 & 1.875 & 306.6 & -24.7 & $1.860 \mathrm{E}-03$ & 3322541172.01562 & 351.60 & 315.0 & -45.0 & 3.650 & 5.525 & 4.763 & 40.6 & 113.3 \\
\hline $1 \mathrm{H}-2$ & 0.400 & 1.900 & 321.0 & -29.5 & $1.576 \mathrm{E}-03$ & 3322541176.93750 & 351.60 & 329.4 & -30.6 & 3.650 & 5.550 & 4.784 & 51.5 & 99.9 \\
\hline $1 \mathrm{H}-2$ & 0.425 & 1.925 & 319.7 & -26.9 & $1.708 \mathrm{E}-03$ & 3322541181.87500 & 351.60 & 328.1 & -31.9 & 3.650 & 5.575 & 4.806 & 51.3 & 103.1 \\
\hline $1 \mathrm{H}-2$ & 0.450 & 1.950 & 321.4 & -25.3 & $1.758 \mathrm{E}-03$ & 3322541186.79687 & 351.60 & 329.8 & -30.2 & 3.650 & 5.600 & 4.828 & 53.2 & 102.9 \\
\hline $1 \mathrm{H}-2$ & 0.475 & 1.975 & 325.5 & -24.0 & $1.722 \mathrm{E}-03$ & 3322541191.73437 & 351.60 & 333.9 & -26.1 & 3.650 & 5.625 & 4.849 & 56.9 & 99.9 \\
\hline $1 \mathrm{H}-2$ & 0.500 & 2.000 & 329.2 & -29.1 & $1.346 \mathrm{E}-03$ & 3322541196.65625 & 351.60 & 337.6 & -22.4 & 3.650 & 5.650 & 4.871 & 57.6 & 91.3 \\
\hline $1 \mathrm{H}-2$ & 0.525 & 2.025 & 327.6 & -56.8 & $7.402 \mathrm{E}-04$ & 3322541201.59375 & 351.60 & 336.0 & -24.0 & 3.650 & 5.675 & 4.892 & 39.4 & 72.7 \\
\hline $1 \mathrm{H}-2$ & 0.550 & 2.050 & 141.2 & -34.1 & $1.030 \mathrm{E}-03$ & 3322541206.53125 & 351.60 & 149.6 & 149.6 & 3.650 & 5.700 & 4.914 & -58.6 & 341.1 \\
\hline $1 \mathrm{H}-2$ & 0.575 & 2.075 & 154.8 & -15.3 & $1.689 \mathrm{E}-03$ & 3322541211.45312 & 351.60 & 163.2 & 163.2 & 3.650 & 5.725 & 4.935 & -73.4 & 318.5 \\
\hline $1 \mathrm{H}-2$ & 0.600 & 2.100 & 146.5 & -20.2 & $1.683 \mathrm{E}-03$ & 3322541216.39062 & 351.60 & 154.9 & 154.9 & 3.650 & 5.750 & 4.957 & -65.1 & 325.6 \\
\hline $1 \mathrm{H}-2$ & 0.625 & 2.125 & 147.0 & -19.6 & $1.784 \mathrm{E}-03$ & 3322541221.31250 & 351.60 & 155.4 & 155.4 & 3.650 & 5.775 & 4.978 & -65.6 & 324.8 \\
\hline $1 \mathrm{H}-2$ & 0.650 & 2.150 & 145.8 & -19.7 & $1.740 \mathrm{E}-03$ & 3322541226.25000 & 351.60 & 154.2 & 154.2 & 3.650 & 5.800 & 5.000 & -64.4 & 324.8 \\
\hline $1 \mathrm{H}-2$ & 0.675 & 2.175 & 142.7 & -21.0 & $1.442 \mathrm{E}-03$ & 3322541231.18750 & 351.60 & 151.1 & 151.1 & 3.650 & 5.825 & 5.022 & -61.4 & 326.1 \\
\hline $1 \mathrm{H}-2$ & 0.700 & 2.200 & 68.7 & -40.8 & $6.218 \mathrm{E}-04$ & 3322541236.10937 & 351.60 & 77.1 & 77.1 & 3.650 & 5.850 & 5.043 & 8.5 & 343.2 \\
\hline $1 \mathrm{H}-2$ & 0.725 & 2.225 & 357.0 & -17.0 & $1.097 \mathrm{E}-03$ & 3322541241.04687 & 351.60 & 5.4 & 5.4 & 3.650 & 5.875 & 5.065 & 72.5 & 30.0 \\
\hline $1 \mathrm{H}-2$ & 0.750 & 2.250 & 317.3 & -4.6 & $1.703 \mathrm{E}-03$ & 3322541245.98437 & 351.60 & 325.7 & -34.3 & 3.650 & 5.900 & 5.086 & 54.3 & 122.7 \\
\hline $1 \mathrm{H}-2$ & 0.775 & 2.275 & 331.0 & -7.4 & $1.999 \mathrm{E}-03$ & 3322541250.90625 & 351.60 & 339.4 & -20.6 & 3.650 & 5.925 & 5.108 & 66.4 & 109.1 \\
\hline $1 \mathrm{H}-2$ & 0.800 & 2.300 & 331.5 & -5.2 & $2.302 \mathrm{E}-03$ & 3322541255.84375 & 351.60 & 339.9 & -20.1 & 3.650 & 5.950 & 5.129 & 67.3 & 110.9 \\
\hline $1 \mathrm{H}-2$ & 0.825 & 2.325 & 329.8 & -3.8 & $2.335 \mathrm{E}-03$ & 3322541260.78125 & 351.60 & 338.2 & -21.8 & 3.650 & 5.975 & 5.151 & 66.1 & 114.4 \\
\hline $1 \mathrm{H}-2$ & 0.850 & 2.350 & 328.7 & -2.9 & $2.463 \mathrm{E}-03$ & 3322541265.70312 & 351.60 & 337.1 & -22.9 & 3.650 & 6.000 & 5.172 & 65.3 & 116.5 \\
\hline $1 \mathrm{H}-2$ & 0.875 & 2.375 & 326.2 & -1.7 & $3.517 \mathrm{E}-03$ & 3322541270.64062 & 351.60 & 334.6 & -25.4 & 3.650 & 6.025 & 5.194 & 63.2 & 119.9 \\
\hline $1 \mathrm{H}-2$ & 0.900 & 2.400 & 326.3 & -1.1 & $3.122 \mathrm{E}-03$ & 3322541275.56250 & 351.60 & 334.7 & -25.3 & 3.650 & 6.050 & 5.216 & 63.4 & 120.5 \\
\hline $1 \mathrm{H}-2$ & 0.925 & 2.425 & 328.0 & -0.4 & $2.965 \mathrm{E}-03$ & 3322541280.50000 & 351.60 & 336.4 & -23.6 & 3.650 & 6.075 & 5.237 & 65.1 & 119.9 \\
\hline $1 \mathrm{H}-2$ & 0.950 & 2.450 & 329.2 & -0.3 & $2.492 \mathrm{E}-03$ & 3322541285.42187 & 351.60 & 337.6 & -22.4 & 3.650 & 6.100 & 5.259 & 66.2 & 119.0 \\
\hline $1 \mathrm{H}-2$ & 0.975 & 2.475 & 332.3 & -0.9 & $2.148 \mathrm{E}-03$ & 3322541290.35937 & 351.60 & 340.7 & -19.3 & 3.650 & 6.125 & 5.280 & 69.0 & 115.2 \\
\hline $1 \mathrm{H}-2$ & 1.000 & 2.500 & 333.3 & -2.9 & $1.916 \mathrm{E}-03$ & 3322541295.28125 & 351.60 & 341.7 & -18.3 & 3.650 & 6.150 & 5.302 & 69.5 & 111.4 \\
\hline $1 \mathrm{H}-2$ & 1.025 & 2.525 & 342.0 & -8.1 & $1.293 \mathrm{E}-03$ & 3322541300.21875 & 351.60 & 350.4 & -9.6 & 3.650 & 6.175 & 5.323 & 74.6 & 86.8 \\
\hline $1 \mathrm{H}-2$ & 1.050 & 2.550 & 331.8 & -10.2 & $1.425 \mathrm{E}-03$ & 3322541305.15625 & 351.60 & 340.2 & -19.8 & 3.650 & 6.200 & 5.345 & 66.3 & 105.0 \\
\hline $1 \mathrm{H}-2$ & 1.075 & 2.575 & 293.6 & -21.9 & $6.752 \mathrm{E}-04$ & 3322541310.07812 & 351.60 & 302.0 & -58.0 & 3.650 & 6.225 & 5.366 & 29.2 & 120.2 \\
\hline $1 \mathrm{H}-2$ & 1.100 & 2.600 & 135.0 & -12.7 & $9.612 \mathrm{E}-04$ & 3322541315.01562 & 351.60 & 143.4 & 143.4 & 3.650 & 6.250 & 5.388 & -53.7 & 318.0 \\
\hline $1 \mathrm{H}-2$ & 1.125 & 2.625 & 144.3 & -11.1 & $9.040 \mathrm{E}-04$ & 3322541319.93750 & 351.60 & 152.7 & 152.7 & 3.650 & 6.275 & 5.409 & -62.8 & 314.7 \\
\hline $1 \mathrm{H}-2$ & 1.150 & 2.650 & 135.1 & -4.6 & $2.085 \mathrm{E}-03$ & 3322541324.87500 & 351.60 & 143.5 & 143.5 & 3.650 & 6.300 & 5.431 & -53.2 & 311.1 \\
\hline $1 \mathrm{H}-2$ & 1.175 & 2.675 & 156.2 & -3.7 & $2.899 \mathrm{E}-03$ & 3322541329.79687 & 351.60 & 164.6 & 164.6 & 3.650 & 6.325 & 5.453 & -73.5 & 297.0 \\
\hline $1 \mathrm{H}-2$ & 1.200 & 2.700 & 149.5 & -4.6 & $2.412 \mathrm{E}-03$ & 3322541334.73437 & 351.60 & 157.9 & 157.9 & 3.650 & 6.350 & 5.474 & -67.3 & 304.7 \\
\hline $1 \mathrm{H}-2$ & 1.225 & 2.725 & 151.1 & -3.7 & 2.477E-03 & 3322541339.65625 & 351.60 & 159.5 & 159.5 & 3.650 & 6.375 & 5.496 & -68.7 & 302.3 \\
\hline $1 \mathrm{H}-2$ & 1.250 & 2.750 & 152.0 & -3.4 & $2.300 \mathrm{E}-03$ & 3322541344.59375 & 351.60 & 160.4 & 160.4 & 3.650 & 6.400 & 5.517 & -69.5 & 301.2 \\
\hline $1 \mathrm{H}-2$ & 1.275 & 2.775 & 152.8 & -4.6 & $2.145 \mathrm{E}-03$ & 3322541349.53125 & 351.60 & 161.2 & 161.2 & 3.650 & 6.425 & 5.539 & -70.4 & 302.1 \\
\hline $1 \mathrm{H}-2$ & 1.300 & 2.800 & 151.8 & -5.5 & $2.289 \mathrm{E}-03$ & 3322541354.45312 & 351.60 & 160.2 & 160.2 & 3.650 & 6.450 & 5.560 & -69.6 & 304.2 \\
\hline $1 \mathrm{H}-2$ & 1.325 & 2.825 & 149.4 & -6.2 & $2.549 \mathrm{E}-03$ & 3322541359.39062 & 351.60 & 157.8 & 157.8 & 3.650 & 6.475 & 5.582 & -67.4 & 306.8 \\
\hline
\end{tabular}


Table T18. Mean paleomagnetic direction for each core from Site U1334. (See table notes.)

\begin{tabular}{|c|c|c|c|c|c|c|}
\hline Core & $\begin{array}{c}\text { Inclination } \\
\left(^{\circ}\right)\end{array}$ & $\begin{array}{l}\text { Declination } \\
\left({ }^{\circ}\right)\end{array}$ & N & $R$ & $k$ & $\begin{array}{c}\alpha 95 \\
\left(^{\circ}\right)\end{array}$ \\
\hline \multicolumn{7}{|c|}{ 320-U1334A- } \\
\hline $1 \mathrm{H}$ & 11.7 & 227.8 & 120 & 112.623 & 16.1 & 3.3 \\
\hline $2 \mathrm{H}$ & 7.2 & 134.2 & 134 & 120.206 & 9.6 & 4.1 \\
\hline $3 \mathrm{H}$ & 8.6 & 58.0 & 147 & 135.995 & 13.3 & 3.3 \\
\hline $4 \mathrm{H}$ & 2.9 & 298.4 & 186 & 178.691 & 25.3 & 2.1 \\
\hline $5 \mathrm{H}$ & 9.2 & 65.4 & 156 & 148.936 & 21.9 & 2.5 \\
\hline $6 \mathrm{H}$ & 8.5 & 92.8 & 166 & 159.091 & 23.9 & 2.3 \\
\hline $7 \mathrm{H}$ & 1.8 & 79.1 & 146 & 137.247 & 16.6 & 3.0 \\
\hline $8 \mathrm{H}$ & -13.2 & 329.7 & 132 & 123.986 & 16.3 & 3.1 \\
\hline $9 \mathrm{H}$ & 18.7 & 221.3 & 153 & 146.716 & 24.2 & 2.4 \\
\hline $10 \mathrm{H}$ & -6.9 & 330.0 & 135 & 128.361 & 20.2 & 2.8 \\
\hline $11 \mathrm{H}$ & -10.9 & 260.8 & 150 & 142.763 & 20.6 & 2.6 \\
\hline $12 \mathrm{H}$ & 4.8 & 274.1 & 149 & 143.049 & 24.9 & 2.4 \\
\hline $13 \mathrm{H}$ & -8.2 & 6.2 & 148 & 140.124 & 18.7 & 2.8 \\
\hline $14 \mathrm{H}$ & 5.5 & 104.0 & 165 & 162.648 & 69.7 & 1.3 \\
\hline $15 \mathrm{H}$ & -21.1 & 323.3 & 135 & 128.225 & 19.8 & 2.8 \\
\hline $16 \mathrm{H}$ & 2.0 & 66.2 & 114 & 106.717 & 15.5 & 3.5 \\
\hline $17 \mathrm{H}$ & 0.4 & 261.9 & 79 & 73.061 & 13.1 & 4.6 \\
\hline $18 \mathrm{H}$ & 27.1 & 353.6 & 99 & 91.602 & 13.2 & 4.1 \\
\hline $19 \mathrm{H}$ & -27.6 & 106.2 & 118 & 108.072 & 11.8 & 4.0 \\
\hline $20 \mathrm{H}$ & 55.9 & 89.6 & 101 & 92.111 & 11.3 & 4.4 \\
\hline $21 \mathrm{H}$ & 31.4 & 246.6 & 58 & 51.331 & 8.5 & 6.8 \\
\hline $22 \mathrm{H}$ & * & * & & & & \\
\hline \multicolumn{7}{|c|}{ 320-U1334B- } \\
\hline $1 \mathrm{H}$ & 10.3 & 23.8 & 122 & 112.636 & 12.9 & 3.7 \\
\hline $2 \mathrm{H}$ & 15.2 & 277.2 & 126 & 114.806 & 11.2 & 3.9 \\
\hline $3 \mathrm{H}$ & -1.5 & 174.3 & 138 & 126.630 & 12.0 & 3.6 \\
\hline $4 \mathrm{H}$ & 7.8 & 217.1 & 161 & 153.013 & 20.0 & 2.5 \\
\hline $5 \mathrm{H}$ & 18.5 & 95.2 & 122 & 119.798 & 55.0 & 1.7 \\
\hline $6 \mathrm{H}$ & -0.1 & 342.7 & 150 & 142.110 & 18.9 & 2.7 \\
\hline $7 \mathrm{H}$ & -11.7 & 235.6 & 131 & 124.508 & 20.0 & 2.8 \\
\hline $8 \mathrm{H}$ & -1.7 & 315.6 & 151 & 141.200 & 15.3 & 3.0 \\
\hline $9 \mathrm{H}$ & -3.6 & 326.0 & 137 & 124.714 & 11.1 & 3.8 \\
\hline $10 \mathrm{H}$ & -11.4 & 305.6 & 120 & 111.938 & 14.8 & 3.5 \\
\hline $11 \mathrm{H}$ & -0.2 & 142.0 & 152 & 138.740 & 11.4 & 3.5 \\
\hline
\end{tabular}

\begin{tabular}{|c|c|c|c|c|c|c|}
\hline Core & $\begin{array}{c}\text { Inclination } \\
\left(^{\circ}\right)\end{array}$ & $\begin{array}{c}\text { Declination } \\
\left({ }^{\circ}\right)\end{array}$ & N & $R$ & $k$ & $\begin{array}{c}\alpha 95 \\
\left(^{\circ}\right)\end{array}$ \\
\hline $12 \mathrm{H}$ & -10.5 & 10.3 & 150 & 143.804 & 24.0 & 2.4 \\
\hline $13 \mathrm{H}$ & 2.9 & 286.0 & 145 & 139.793 & 27.7 & 2.3 \\
\hline $14 \mathrm{H}$ & -5.4 & 253.9 & 132 & 121.035 & 11.9 & 3.7 \\
\hline $15 \mathrm{H}$ & -0.2 & 261.6 & 132 & 122.897 & 14.4 & 3.4 \\
\hline $16 \mathrm{H}$ & 3.9 & 295.8 & 62 & 53.998 & 7.6 & 7.0 \\
\hline $17 \mathrm{H}$ & 0.7 & 200.1 & 52 & 44.784 & 7.1 & 8.0 \\
\hline $18 \mathrm{H}$ & -29.0 & 293.7 & 120 & 108.173 & 10.1 & 4.3 \\
\hline $19 \mathrm{H}$ & -53.6 & 253.4 & 118 & 108.178 & 11.9 & 3.9 \\
\hline $20 \mathrm{H}$ & 32.0 & 288.6 & 112 & 99.711 & 9.0 & 4.7 \\
\hline $21 \mathrm{H}$ & 30.4 & 321.0 & 149 & 134.251 & 10.0 & 3.8 \\
\hline $22 \mathrm{H}$ & -12.1 & 173.3 & 159 & 138.893 & 7.9 & 4.3 \\
\hline \multicolumn{7}{|c|}{ 320-U1334C- } \\
\hline $1 \mathrm{H}$ & 5.3 & 351.6 & 261 & 247.926 & 19.9 & 2.0 \\
\hline $2 \mathrm{H}$ & 9.5 & 302.0 & 130 & 122.553 & 17.3 & 3.1 \\
\hline $3 \mathrm{H}$ & 10.4 & 107.3 & 137 & 132.448 & 29.9 & 2.2 \\
\hline $4 \mathrm{H}$ & 9.0 & 164.8 & 163 & 154.399 & 18.8 & 2.6 \\
\hline $5 \mathrm{H}$ & 3.0 & 258.0 & 166 & 162.917 & 53.5 & 1.5 \\
\hline $6 \mathrm{H}$ & 2.4 & 355.7 & 324 & 311.366 & 25.6 & 1.6 \\
\hline $7 \mathrm{H}$ & 4.9 & 107.3 & 267 & 254.358 & 21.0 & 1.9 \\
\hline $8 \mathrm{H}$ & -3.2 & 64.4 & 431 & 413.746 & 24.9 & 1.4 \\
\hline $9 \mathrm{H}$ & 7.6 & 217.4 & 403 & 385.526 & 23.0 & 1.5 \\
\hline $10 \mathrm{H}$ & -3.3 & 264.5 & 449 & 412.650 & 12.3 & 2.0 \\
\hline $11 \mathrm{H}$ & -0.5 & 340.1 & 369 & 358.227 & 34.2 & 1.3 \\
\hline $12 \mathrm{H}$ & -1.8 & 221.5 & 309 & 290.940 & 17.1 & 2.0 \\
\hline $13 \mathrm{H}$ & 8.0 & 359.9 & 330 & 303.895 & 12.6 & 2.3 \\
\hline $14 \mathrm{H}$ & -18.0 & 37.2 & 221 & 210.733 & 21.4 & 2.1 \\
\hline $15 \mathrm{H}$ & 14.4 & 254.6 & 114 & 104.431 & 11.8 & 4.0 \\
\hline $16 \mathrm{H}$ & -2.2 & 323.8 & 92 & 81.728 & 8.9 & 5.3 \\
\hline $17 \mathrm{H}$ & 7.0 & 57.6 & 86 & 75.741 & 8.3 & 5.7 \\
\hline $18 \mathrm{H}$ & -38.9 & 156.6 & 132 & 122.317 & 13.5 & 3.5 \\
\hline $19 \mathrm{H}$ & -50.0 & 9.4 & 117 & 105.676 & 10.2 & 4.3 \\
\hline $20 \mathrm{H}$ & 33.0 & 69.3 & 99 & 89.836 & 10.7 & 4.6 \\
\hline $21 \mathrm{H}$ & 18.8 & 162.5 & 195 & 174.843 & 9.6 & 3.4 \\
\hline $22 \mathrm{H}$ & * & * & & & & \\
\hline
\end{tabular}

Notes: Mean paleomagnetic directions and statistics calculated using Fisher statistics for each core. We used data from stable polarity intervals. Reversed polarity intervals were inverted prior to computing mean directions and statistics. Inclination = mean paleomagnetic inclination from stable polarity intervals in core, declination = mean paleomagnetic declination from stable polarity intervals in core. By subtracting this value from observed paleomagnetic declinations measured along core, core can be approximately reoriented back into geographic coordinates. After reorientation, normal polarity intervals will have $\sim 0^{\circ}$ declination and reversed polarity intervals will have $\sim 180^{\circ}$ declination. $N=$ number of paleomagnetic observations used in calculating mean, $R=$ resultant vector length from summing $\mathrm{N}$ vectors (directions or poles), $k$ $=$ precision parameter from Fisher statistical calculations, $\alpha 95=95 \%$ confidence angle for mean direction. ${ }^{*}=$ mean direction in determinate. 
Table T19. Paleomagnetic results for discrete samples, Hole U1334A. (See table notes.)

\begin{tabular}{|c|c|c|c|c|c|c|c|}
\hline \multirow{3}{*}{$\begin{array}{l}\text { Core, section, } \\
\text { interval }(\mathrm{cm})\end{array}$} & \multirow{3}{*}{$\begin{array}{l}\text { Depth } \\
\text { CSF (m) }\end{array}$} & \multirow{3}{*}{$\begin{array}{c}\text { Demag } \\
(\mathrm{mT})\end{array}$} & \multicolumn{3}{|c|}{ Declination } & \multirow{3}{*}{$\begin{array}{c}\text { Inclination } \\
\left(^{\circ}\right)\end{array}$} & \multirow{3}{*}{$\begin{array}{c}\text { Intensity } \\
(\mathrm{A} / \mathrm{m})\end{array}$} \\
\hline & & & \multirow{2}{*}{$\begin{array}{c}\text { Azimuthally } \\
\text { unoriented }\left({ }^{\circ}\right)\end{array}$} & \multicolumn{2}{|c|}{ Geographical coordinates } & & \\
\hline & & & & $0^{\circ}-360^{\circ}$ & $-90^{\circ}-270^{\circ}$ & & \\
\hline \multicolumn{8}{|l|}{ 320-U1334A- } \\
\hline $1 \mathrm{H}-2,85$ & 2.35 & 0 & 80.6 & 212.8 & 212.8 & 51.3 & $3.50 \mathrm{E}-04$ \\
\hline $1 \mathrm{H}-2,85$ & 2.35 & 5 & 44.1 & 176.3 & 176.3 & -5.5 & $1.18 \mathrm{E}-03$ \\
\hline $1 \mathrm{H}-2,85$ & 2.35 & 10 & 55.9 & 188.1 & 188.1 & -9.1 & $1.14 \mathrm{E}-03$ \\
\hline $1 \mathrm{H}-2,85$ & 2.35 & 15 & 63.8 & 196.0 & 196.0 & -7.8 & $1.09 \mathrm{E}-03$ \\
\hline $1 \mathrm{H}-2,85$ & 2.35 & 20 & 70.5 & 202.7 & 202.7 & -4.5 & $9.11 \mathrm{E}-04$ \\
\hline $1 \mathrm{H}-2,85$ & 2.35 & 25 & 68.4 & 200.6 & 200.6 & 1.8 & $8.08 \mathrm{E}-04$ \\
\hline $1 \mathrm{H}-2,85$ & 2.35 & 30 & 66.9 & 199.1 & 199.1 & 6.6 & $5.98 \mathrm{E}-04$ \\
\hline $1 \mathrm{H}-2,85$ & 2.35 & 35 & 61.3 & 193.5 & 193.5 & 16.9 & $5.66 \mathrm{E}-04$ \\
\hline $1 \mathrm{H}-2,85$ & 2.35 & 40 & 75.9 & 208.1 & 208.1 & 19.2 & $4.66 \mathrm{E}-04$ \\
\hline $1 \mathrm{H}-2,85$ & 2.35 & 50 & 25.6 & 157.8 & 157.8 & 37.1 & $6.68 \mathrm{E}-04$ \\
\hline $1 \mathrm{H}-2,85$ & 2.35 & 60 & 12.7 & 144.9 & 144.9 & 74.2 & $5.62 \mathrm{E}-04$ \\
\hline $1 \mathrm{H}-3,85$ & 3.85 & 0 & -143.2 & -11.0 & -11.0 & 31.4 & $3.78 \mathrm{E}-03$ \\
\hline $1 \mathrm{H}-3,85$ & 3.85 & 5 & -163.3 & -31.1 & -31.1 & 40.6 & $1.27 \mathrm{E}-03$ \\
\hline $1 \mathrm{H}-3,85$ & 3.85 & 10 & 46.6 & 178.8 & 178.8 & 13.9 & $1.26 \mathrm{E}-03$ \\
\hline $1 \mathrm{H}-3,85$ & 3.85 & 15 & 46.5 & 178.7 & 178.7 & 18.2 & $1.34 \mathrm{E}-03$ \\
\hline $1 \mathrm{H}-3,85$ & 3.85 & 20 & 45.6 & 177.8 & 177.8 & 24.9 & $1.29 \mathrm{E}-03$ \\
\hline $1 \mathrm{H}-3,85$ & 3.85 & 25 & 50.8 & 183.0 & 183.0 & 44.4 & $1.13 \mathrm{E}-03$ \\
\hline $1 \mathrm{H}-3,85$ & 3.85 & 30 & 77.6 & 209.8 & 209.8 & 63.7 & $1.03 \mathrm{E}-03$ \\
\hline $1 \mathrm{H}-3,85$ & 3.85 & 35 & 31.3 & 163.5 & 163.5 & 62.4 & $1.51 \mathrm{E}-03$ \\
\hline $1 \mathrm{H}-3,85$ & 3.85 & 40 & 116.9 & 249.1 & 249.1 & 78.6 & $1.24 \mathrm{E}-03$ \\
\hline $1 \mathrm{H}-3,85$ & 3.85 & 50 & -122.7 & 9.5 & 9.5 & 85.5 & $1.27 \mathrm{E}-03$ \\
\hline $1 \mathrm{H}-3,85$ & 3.85 & 60 & -165.7 & -33.5 & -33.5 & 77.7 & $1.70 \mathrm{E}-03$ \\
\hline $1 \mathrm{H}-5,85$ & 6.85 & 0 & -49.1 & 83.1 & 83.1 & 65.3 & $3.17 \mathrm{E}-03$ \\
\hline $1 \mathrm{H}-5,85$ & 6.85 & 5 & 41.9 & 174.1 & 174.1 & 30.7 & $1.35 \mathrm{E}-03$ \\
\hline $1 \mathrm{H}-5,85$ & 6.85 & 10 & 50.8 & 183.0 & 183.0 & 3.4 & $2.19 \mathrm{E}-03$ \\
\hline $1 \mathrm{H}-5,85$ & 6.85 & 15 & 43.0 & 175.2 & 175.2 & 4.0 & $2.65 \mathrm{E}-03$ \\
\hline $1 \mathrm{H}-5,85$ & 6.85 & 20 & 49.2 & 181.4 & 181.4 & 7.1 & $2.13 \mathrm{E}-03$ \\
\hline $1 \mathrm{H}-5,85$ & 6.85 & 25 & 49.2 & 181.4 & 181.4 & 11.9 & $1.88 \mathrm{E}-03$ \\
\hline $1 \mathrm{H}-5,85$ & 6.85 & 30 & 59.5 & 191.7 & 191.7 & 23.8 & $1.24 \mathrm{E}-03$ \\
\hline $1 \mathrm{H}-5,85$ & 6.85 & 35 & 42.1 & 174.3 & 174.3 & 33.4 & $1.14 \mathrm{E}-03$ \\
\hline $1 \mathrm{H}-5,85$ & 6.85 & 40 & 47.9 & 180.1 & 180.1 & 49.9 & $1.04 \mathrm{E}-03$ \\
\hline $1 \mathrm{H}-5,85$ & 6.85 & 50 & 78.6 & 210.8 & 210.8 & 75.9 & $9.94 \mathrm{E}-04$ \\
\hline $1 \mathrm{H}-5,85$ & 6.85 & 60 & 43.7 & 175.9 & 175.9 & 81.0 & $1.02 \mathrm{E}-03$ \\
\hline $2 \mathrm{H}-2,85$ & 10.55 & 0 & 54.2 & 280.0 & -80.0 & 81.5 & $3.00 \mathrm{E}-03$ \\
\hline $2 \mathrm{H}-2,85$ & 10.55 & 5 & 113.1 & 338.9 & -21.1 & 19.1 & 2.97E-03 \\
\hline $2 \mathrm{H}-2,85$ & 10.55 & 10 & 128.9 & 354.7 & -5.3 & 16.4 & $1.68 \mathrm{E}-03$ \\
\hline $2 \mathrm{H}-2,85$ & 10.55 & 15 & 125.6 & 351.4 & -8.6 & 24.2 & $1.19 \mathrm{E}-03$ \\
\hline $2 \mathrm{H}-2,85$ & 10.55 & 20 & 128.8 & 354.6 & -5.4 & 30.5 & $1.11 \mathrm{E}-03$ \\
\hline $2 \mathrm{H}-2,85$ & 10.55 & 25 & 128.3 & 354.1 & -5.9 & 45.1 & $1.01 \mathrm{E}-03$ \\
\hline $2 \mathrm{H}-2,85$ & 10.55 & 30 & 130.3 & 356.1 & -3.9 & 51.8 & $1.08 \mathrm{E}-03$ \\
\hline $2 \mathrm{H}-2,85$ & 10.55 & 35 & 133.4 & 359.2 & -0.8 & 66.4 & $9.88 \mathrm{E}-04$ \\
\hline $2 \mathrm{H}-2,85$ & 10.55 & 40 & 131.4 & 357.2 & -2.8 & 70.6 & $1.05 \mathrm{E}-03$ \\
\hline $2 \mathrm{H}-2,85$ & 10.55 & 50 & 76.6 & 302.4 & -57.6 & 80.4 & $1.32 \mathrm{E}-03$ \\
\hline $2 \mathrm{H}-2,85$ & 10.55 & 60 & -134.7 & 91.1 & 91.1 & 88.2 & $1.34 \mathrm{E}-03$ \\
\hline $2 \mathrm{H}-3,85$ & 12.05 & 0 & 107.6 & 333.4 & -26.6 & 65.8 & $2.20 \mathrm{E}-03$ \\
\hline $2 \mathrm{H}-3,85$ & 12.05 & 5 & 119.1 & 344.9 & -15.1 & 19.5 & $4.14 \mathrm{E}-03$ \\
\hline $2 \mathrm{H}-3,85$ & 12.05 & 10 & 113.6 & 339.4 & -20.6 & 21.4 & $2.58 \mathrm{E}-03$ \\
\hline $2 \mathrm{H}-3,85$ & 12.05 & 15 & 115.7 & 341.5 & -18.5 & 27.5 & $2.11 \mathrm{E}-03$ \\
\hline $2 \mathrm{H}-3,85$ & 12.05 & 20 & 107.5 & 333.3 & -26.7 & 34.0 & $1.81 \mathrm{E}-03$ \\
\hline $2 \mathrm{H}-3,85$ & 12.05 & 25 & 124.9 & 350.7 & -9.3 & 37.1 & $1.76 \mathrm{E}-03$ \\
\hline $2 \mathrm{H}-3,85$ & 12.05 & 30 & 136.8 & 2.6 & 2.6 & 41.6 & $1.56 \mathrm{E}-03$ \\
\hline $2 \mathrm{H}-3,85$ & 12.05 & 35 & 92.0 & 317.8 & -42.2 & 64.6 & $1.48 \mathrm{E}-03$ \\
\hline $2 \mathrm{H}-3,85$ & 12.05 & 40 & 99.4 & 325.2 & -34.8 & 67.6 & $1.52 \mathrm{E}-03$ \\
\hline $2 \mathrm{H}-3,85$ & 12.05 & 50 & 149.1 & 14.9 & 14.9 & 66.2 & $1.34 \mathrm{E}-03$ \\
\hline $2 \mathrm{H}-3,85$ & 12.05 & 60 & 63.3 & 289.1 & -70.9 & 83.0 & $1.42 \mathrm{E}-03$ \\
\hline $2 \mathrm{H}-5,85$ & 15.05 & 0 & 113.3 & 339.1 & -20.9 & 26.4 & $2.70 \mathrm{E}-03$ \\
\hline $2 \mathrm{H}-5,85$ & 15.05 & 5 & 155.4 & 21.2 & 21.2 & 63.8 & $6.35 \mathrm{E}-04$ \\
\hline $2 \mathrm{H}-5,85$ & 15.05 & 10 & -91.1 & 134.7 & 134.7 & 0.9 & $7.06 \mathrm{E}-04$ \\
\hline $2 \mathrm{H}-5,85$ & 15.05 & 15 & -52.9 & 172.9 & 172.9 & 7.9 & $6.94 \mathrm{E}-04$ \\
\hline $2 \mathrm{H}-5,85$ & 15.05 & 20 & -55.6 & 170.2 & 170.2 & 15.3 & 7.97E-04 \\
\hline $2 \mathrm{H}-5,85$ & 15.05 & 25 & -39.7 & 186.1 & 186.1 & 26.3 & 7.03E-04 \\
\hline
\end{tabular}

Notes: Only a portion of this table appears here. The complete table is available in ASCII. 
Table T20. Principal component analysis (PCA) results for paleomagnetic data, Hole U1334A. (See table notes). (Continued on next page.)

\begin{tabular}{|c|c|c|c|c|c|c|c|c|c|c|}
\hline \multirow[b]{3}{*}{$\begin{array}{l}\text { Core, section, } \\
\text { interval }(\mathrm{cm})\end{array}$} & \multirow[b]{3}{*}{$\begin{array}{l}\text { Depth } \\
\operatorname{CSF}(m)\end{array}$} & \multicolumn{5}{|c|}{ PCA } & \multirow[b]{3}{*}{$\begin{array}{l}\text { NRM } 20 \mathrm{mT} \\
(\mathrm{A} / \mathrm{m})\end{array}$} & \multirow{2}{*}{\multicolumn{3}{|c|}{$\begin{array}{c}\text { Archive-half section at } 20 \mathrm{mT} \mathrm{AF} \\
\text { demagnetization }\end{array}$}} \\
\hline & & \multicolumn{2}{|c|}{ Declination } & \multirow[b]{2}{*}{$\begin{array}{c}\text { Inclination } \\
\left({ }^{\circ}\right)\end{array}$} & \multirow[b]{2}{*}{$\begin{array}{c}\text { MAD } \\
\left({ }^{\circ}\right)\end{array}$} & \multirow[b]{2}{*}{$\begin{array}{l}\text { Range } \\
(\mathrm{mT})\end{array}$} & & & & \\
\hline & & $\begin{array}{c}\text { unoriented } \\
\left({ }^{\circ}\right)\end{array}$ & $\begin{array}{l}\text { coordinates } \\
\left(0^{\circ}-360^{\circ}\right)\end{array}$ & & & & & $\begin{array}{c}\text { Declination } \\
\left({ }^{\circ}\right)\end{array}$ & $\begin{array}{l}\text { Inclination } \\
\left({ }^{\circ}\right)\end{array}$ & $\begin{array}{l}\text { NRM } \\
(A / m)\end{array}$ \\
\hline \multicolumn{11}{|l|}{ 320-U1334A- } \\
\hline $1 \mathrm{H}-2,85$ & 2.35 & 63.4 & 134.6 & -26.3 & 12.0 & $15-40$ & $9.11 \mathrm{E}-04$ & 163.1 & -12.7 & $2.037 \mathrm{E}-03$ \\
\hline $1 \mathrm{H}-3,85$ & 3.85 & NA & & NA & NA & NA & $1.29 \mathrm{E}-03$ & 2.5 & 45.2 & $8.673 \mathrm{E}-04$ \\
\hline $1 \mathrm{H}-5,85$ & 6.85 & 33.4 & 139.1 & -13.1 & 10.4 & $10-30$ & $2.13 \mathrm{E}-03$ & 185.3 & 13.9 & $1.516 \mathrm{E}-03$ \\
\hline $2 \mathrm{H}-2,85$ & 10.55 & 107.1 & 236.4 & 9.8 & 13.0 & $5-25$ & $1.11 \mathrm{E}-03$ & 353.6 & 23.2 & $2.072 \mathrm{E}-03$ \\
\hline $2 \mathrm{H}-3,85$ & 12.05 & 120.6 & 237.9 & 8.0 & 11.2 & $5-25$ & $1.81 \mathrm{E}-03$ & 345.2 & 30.0 & $2.178 \mathrm{E}-03$ \\
\hline $2 \mathrm{H}-5,85$ & 15.05 & 33.4 & 240.9 & 35.7 & 24.9 & $10-30$ & 7.97E-04 & 152.2 & 57.6 & $6.175 \mathrm{E}-04$ \\
\hline $3 \mathrm{H}-2,85$ & 20.05 & 43.2 & 322.1 & 11.6 & 6.4 & $5-25$ & $9.38 \mathrm{E}-04$ & 6.6 & 28.0 & $1.415 \mathrm{E}-03$ \\
\hline $3 \mathrm{H}-3,85$ & 21.55 & 63.6 & 323.6 & 3.3 & 10.7 & $5-25$ & $1.90 \mathrm{E}-03$ & 358.6 & 19.9 & $2.777 \mathrm{E}-03$ \\
\hline $3 \mathrm{H}-5,85$ & 24.55 & 57.8 & 326.6 & 4.5 & 12.1 & $5-25$ & $3.07 \mathrm{E}-03$ & 357.3 & 20.1 & $3.021 \mathrm{E}-03$ \\
\hline $4 \mathrm{H}-2,85$ & 29.55 & 106.3 & 91.2 & -20.0 & 15.4 & $15-40$ & $1.01 \mathrm{E}-03$ & 171.7 & -12.2 & $1.193 \mathrm{E}-03$ \\
\hline $4 \mathrm{H}-3,85$ & 31.05 & 126.3 & 92.7 & -12.6 & 19.8 & $10-50$ & $2.18 \mathrm{E}-03$ & 186.1 & 2.2 & $1.808 \mathrm{E}-03$ \\
\hline $4 \mathrm{H}-5,85$ & 34.05 & 295.2 & 95.7 & -3.6 & 22.2 & $5-35$ & $1.51 \mathrm{E}-03$ & 4.2 & 10.1 & $1.624 \mathrm{E}-03$ \\
\hline $5 \mathrm{H}-2,85$ & 39.05 & 239.6 & 333.7 & -12.8 & 9.9 & $15-35$ & $3.25 \mathrm{E}-03$ & 179.1 & 3.2 & $3.418 \mathrm{E}-03$ \\
\hline $5 \mathrm{H}-3,85$ & 40.55 & 88.2 & 335.2 & 33.2 & 16.3 & $5-60$ & $2.39 \mathrm{E}-03$ & 14.0 & 35.6 & $2.621 \mathrm{E}-03$ \\
\hline $5 \mathrm{H}-5,85$ & 43.55 & 80.2 & 338.2 & -13.6 & 15.2 & $5-60$ & $2.22 \mathrm{E}-03$ & 6.3 & 23.5 & $1.169 \mathrm{E}-03$ \\
\hline $6 \mathrm{H}-2,85$ & 48.55 & NA & & NA & NA & NA & $3.55 \mathrm{E}-04$ & 359.2 & 13.1 & $2.336 \mathrm{E}-04$ \\
\hline $6 \mathrm{H}-3,85$ & 50.05 & 168.6 & 317.3 & 13.9 & 7.0 & $5-25$ & $5.49 \mathrm{E}-04$ & 334.0 & 36.9 & $4.760 \mathrm{E}-04$ \\
\hline $6 \mathrm{H}-5,85$ & 53.05 & 265.2 & 320.3 & -16.0 & 38.0 & $10-60$ & $7.25 \mathrm{E}-04$ & 181.6 & -8.8 & $8.246 \mathrm{E}-04$ \\
\hline $7 \mathrm{H}-2,85$ & 58.05 & 85.7 & 339.0 & -2.8 & 28.6 & $5-30$ & $9.65 \mathrm{E}-04$ & 359.8 & 8.5 & $1.002 \mathrm{E}-03$ \\
\hline $7 \mathrm{H}-3,85$ & 59.55 & 81.2 & 340.5 & 40.8 & 28.4 & $0-25$ & $4.63 \mathrm{E}-04$ & 356.2 & 47.5 & $4.271 \mathrm{E}-04$ \\
\hline 7H- 5,85 & 61.05 & NA & & NA & NA & NA & $4.07 \mathrm{E}-04$ & 184.9 & 7.4 & $7.120 \mathrm{E}-04$ \\
\hline $8 \mathrm{H}-2,85$ & 67.55 & 214.7 & 97.9 & 15.7 & 18.1 & $5-25$ & $2.78 \mathrm{E}-04$ & 186.1 & -0.4 & $3.744 \mathrm{E}-04$ \\
\hline $8 \mathrm{H}-3,85$ & 69.05 & 176.1 & 99.4 & -2.0 & 6.0 & $5-25$ & $4.95 \mathrm{E}-04$ & 168.6 & -4.7 & $5.342 \mathrm{E}-04$ \\
\hline $8 \mathrm{H}-5,85$ & 72.05 & 340.2 & 102.4 & 5.2 & 10.2 & $15-35$ & $4.06 \mathrm{E}-04$ & 354.5 & 11.7 & $5.936 \mathrm{E}-04$ \\
\hline $9 \mathrm{H}-2,85$ & 77.05 & 202.6 & 215.8 & 13.2 & 11.9 & $5-50$ & $6.15 \mathrm{E}-04$ & 359.6 & 15.4 & $8.004 \mathrm{E}-04$ \\
\hline $9 \mathrm{H}-3,85$ & 78.55 & 199.6 & 217.3 & 0.4 & 4.4 & $5-25$ & $5.09 \mathrm{E}-04$ & 316.9 & 53.6 & $5.149 \mathrm{E}-04$ \\
\hline $9 \mathrm{H}-5,85$ & 81.55 & 193.4 & 220.3 & -4.5 & 14.4 & $5-60$ & $4.45 \mathrm{E}-04$ & 7.1 & 14.4 & $5.940 \mathrm{E}-04$ \\
\hline $10 \mathrm{H}-2,85$ & 86.55 & 150.9 & 116.6 & -18.4 & 19.9 & $15-40$ & $4.08 \mathrm{E}-04$ & 179.6 & 0.7 & $4.721 \mathrm{E}-04$ \\
\hline $10 \mathrm{H}-3,85$ & 88.05 & 63.9 & 118.1 & 20.6 & 43.3 & $5-60$ & $6.95 \mathrm{E}-04$ & 356.4 & 2.9 & $8.175 \mathrm{E}-04$ \\
\hline $10 \mathrm{H}-5,85$ & 91.05 & NA & & NA & NA & NA & $2.87 \mathrm{E}-04$ & 200.4 & 68.9 & $1.220 \mathrm{E}-04$ \\
\hline $11 \mathrm{H}-2,85$ & 96.05 & 209.8 & 195.3 & 24.9 & 17.9 & $5-25$ & $3.15 \mathrm{E}-04$ & 217.1 & 36.4 & $4.563 \mathrm{E}-04$ \\
\hline $11 \mathrm{H}-3,85$ & 97.55 & NA & & NA & NA & NA & $4.48 \mathrm{E}-04$ & 185.6 & 48.1 & $2.319 \mathrm{E}-04$ \\
\hline $11 \mathrm{H}-5,85$ & 100.55 & 65.9 & 199.8 & -2.2 & 5.9 & $15-35$ & $1.12 \mathrm{E}-03$ & 176.2 & 6.4 & $1.112 \mathrm{E}-03$ \\
\hline $12 \mathrm{H}-2,85$ & 105.55 & 201.9 & 191.5 & -10.4 & 33.2 & $5-25$ & $2.24 \mathrm{E}-04$ & 174.2 & 3.6 & $1.071 \mathrm{E}-03$ \\
\hline $12 \mathrm{H}-3,85$ & 107.05 & 262.2 & 193.0 & -5.1 & 25.1 & $5-30$ & $9.90 \mathrm{E}-04$ & 352.4 & 9.4 & $1.036 \mathrm{E}-03$ \\
\hline $12 \mathrm{H}-5,85$ & 110.05 & 286.2 & 196.0 & -0.1 & 17.6 & $5-50$ & $1.28 \mathrm{E}-03$ & 13.7 & 6.3 & 1.687E-03 \\
\hline $13 \mathrm{H}-2,85$ & 114.05 & 197.7 & 107.9 & -11.1 & 4.9 & $10-30$ & $6.80 \mathrm{E}-04$ & 180.3 & 16.3 & $1.104 \mathrm{E}-03$ \\
\hline $13 \mathrm{H}-3,85$ & 115.55 & 0.5 & 109.4 & -8.2 & 11.4 & $5-35$ & $3.40 \mathrm{E}-04$ & 3.5 & 2.7 & $3.676 \mathrm{E}-04$ \\
\hline $13 \mathrm{H}-5,85$ & 118.55 & 176.1 & 112.4 & -15.5 & 10.7 & $5-35$ & $7.65 \mathrm{E}-04$ & 165.8 & 8.5 & $6.259 \mathrm{E}-04$ \\
\hline $14 \mathrm{H}-2,85$ & 124.55 & 314.2 & 20.6 & -4.8 & 28.4 & $5-25$ & $5.66 \mathrm{E}-04$ & 354.6 & 19.7 & $4.050 \mathrm{E}-04$ \\
\hline $14 \mathrm{H}-3,85$ & 126.05 & 90.4 & 22.1 & -30.8 & 14.7 & $10-35$ & $9.63 \mathrm{E}-04$ & 356.7 & -2.8 & 1.117E-03 \\
\hline $14 \mathrm{H}-5,85$ & 129.05 & 94.9 & 25.0 & 20.1 & 16.8 & $0-50$ & $1.97 \mathrm{E}-03$ & 357.9 & -4.2 & $1.951 \mathrm{E}-03$ \\
\hline $15 \mathrm{H}-2,85$ & 134.05 & 147.2 & 170.8 & -4.3 & 6.5 & $20-40$ & $8.32 \mathrm{E}-04$ & 175.3 & 16.3 & $1.090 \mathrm{E}-03$ \\
\hline $15 \mathrm{H}-3,85$ & 135.55 & 195.6 & 172.3 & 8.8 & 31.7 & $5-35$ & $4.58 \mathrm{E}-04$ & 158.1 & 25.7 & 7.771E-04 \\
\hline $15 \mathrm{H}-5,85$ & 138.55 & NA & & NA & NA & NA & $3.04 \mathrm{E}-04$ & 212.1 & 22.3 & $5.127 \mathrm{E}-05$ \\
\hline $16 \mathrm{H}-2,85$ & 143.55 & NA & & NA & NA & NA & $4.98 \mathrm{E}-05$ & 357.0 & -11.9 & $3.198 \mathrm{E}-05$ \\
\hline $16 \mathrm{H}-3,85$ & 145.05 & NA & & NA & NA & NA & $7.91 \mathrm{E}-04$ & 5.5 & 5.6 & $3.864 \mathrm{E}-05$ \\
\hline $16 \mathrm{H}-5,85$ & 148.05 & NA & & NA & NA & NA & $2.81 \mathrm{E}-04$ & 23.7 & -4.8 & $1.554 \mathrm{E}-05$ \\
\hline $17 \mathrm{H}-2,85$ & 153.05 & NA & & NA & NA & NA & $1.04 \mathrm{E}-04$ & 340.0 & 66.2 & $8.091 \mathrm{E}-05$ \\
\hline $17 \mathrm{H}-3,85$ & 154.55 & NA & & NA & NA & NA & $6.67 \mathrm{E}-04$ & 15.9 & 2.5 & $1.323 \mathrm{E}-03$ \\
\hline $17 \mathrm{H}-5,85$ & 157.55 & NA & & NA & NA & NA & $1.35 \mathrm{E}-04$ & 210.4 & -5.8 & $6.524 \mathrm{E}-04$ \\
\hline $18 \mathrm{H}-2,85$ & 162.55 & NA & & NA & NA & NA & $2.44 \mathrm{E}-04$ & 1.5 & 13.8 & $1.521 \mathrm{E}-04$ \\
\hline $18 \mathrm{H}-3,85$ & 164.05 & NA & & NA & NA & NA & $6.11 \mathrm{E}-04$ & 32.8 & 28.6 & $1.554 \mathrm{E}-04$ \\
\hline $18 \mathrm{H}-5,85$ & 167.05 & NA & & NA & NA & NA & $4.96 \mathrm{E}-04$ & 173.8 & 42.0 & $1.173 \mathrm{E}-04$ \\
\hline $19 \mathrm{H}-2,85$ & 171.97 & NA & & NA & NA & NA & $3.22 \mathrm{E}-04$ & 242.5 & 16.0 & $3.725 \mathrm{E}-05$ \\
\hline $19 \mathrm{H}-3,85$ & 173.47 & NA & & NA & NA & NA & $8.89 \mathrm{E}-04$ & 178.1 & 32.4 & $7.918 \mathrm{E}-05$ \\
\hline $19 \mathrm{H}-5,85$ & 176.47 & NA & & NA & NA & NA & $6.21 \mathrm{E}-04$ & 174.4 & 52.6 & $3.106 \mathrm{E}-05$ \\
\hline $20 \mathrm{H}-2,85$ & 181.55 & NA & & NA & NA & NA & $3.95 \mathrm{E}-04$ & 275.9 & 69.3 & $4.033 \mathrm{E}-05$ \\
\hline $20 \mathrm{H}-3,85$ & 183.05 & NA & & NA & NA & NA & $4.57 \mathrm{E}-04$ & 359.0 & 39.6 & $3.632 \mathrm{E}-05$ \\
\hline $21 \mathrm{H}-2,85$ & 191.05 & NA & & NA & NA & NA & $4.24 \mathrm{E}-04$ & 85.4 & 50.5 & $8.364 \mathrm{E}-05$ \\
\hline $21 \mathrm{H}-3,85$ & 192.55 & NA & & NA & NA & NA & $1.43 \mathrm{E}-04$ & 298.0 & 76.2 & $1.192 \mathrm{E}-04$ \\
\hline $22 \mathrm{H}-2,85$ & 200.55 & NA & & NA & NA & NA & $3.28 \mathrm{E}-04$ & 52.0 & 38.7 & $3.990 \mathrm{E}-05$ \\
\hline $22 \mathrm{H}-3,85$ & 202.05 & NA & & NA & NA & NA & $2.28 \mathrm{E}-04$ & 167.6 & 5.5 & $1.956 \mathrm{E}-05$ \\
\hline
\end{tabular}


Table T20 (continued).

\begin{tabular}{|c|c|c|c|c|c|c|c|c|c|c|}
\hline \multirow[b]{4}{*}{$\begin{array}{l}\text { Core, section, } \\
\text { interval }(\mathrm{cm})\end{array}$} & \multirow[b]{4}{*}{$\begin{array}{l}\text { Depth } \\
\text { CSF }(m)\end{array}$} & \multicolumn{5}{|c|}{ PCA } & \multirow[b]{4}{*}{$\begin{array}{l}\text { NRM } 20 \mathrm{mT} \\
\quad(\mathrm{A} / \mathrm{m})\end{array}$} & \multirow{3}{*}{\multicolumn{3}{|c|}{$\begin{array}{c}\text { Archive-half section at } 20 \mathrm{mT} \text { AF } \\
\text { demagnetization }\end{array}$}} \\
\hline & & \multicolumn{2}{|c|}{ Declination } & \multirow[b]{3}{*}{$\begin{array}{l}\text { Inclination } \\
\left({ }^{\circ}\right)\end{array}$} & \multirow[b]{3}{*}{$\begin{array}{l}\text { MAD } \\
\left(^{\circ}\right)\end{array}$} & \multirow[b]{3}{*}{$\begin{array}{l}\text { Range } \\
(\mathrm{mT})\end{array}$} & & & & \\
\hline & & Azimuthally & Geographical & & & & & & & \\
\hline & & $\begin{array}{l}\text { unoriented } \\
\left({ }^{\circ}\right)\end{array}$ & $\begin{array}{l}\text { coordinates } \\
\left(0^{\circ}-360^{\circ}\right)\end{array}$ & & & & & $\begin{array}{l}\text { Declination } \\
\left({ }^{\circ}\right)\end{array}$ & $\begin{array}{l}\text { Inclination } \\
\left(^{\circ}\right)\end{array}$ & $\begin{array}{l}\text { NRM } \\
(\mathrm{A} / \mathrm{m})\end{array}$ \\
\hline $23 X-2,105$ & 209.45 & 209.2 & 209.2 & 9.8 & 17.9 & $5-60$ & $1.29 \mathrm{E}-03$ & & & \\
\hline $23 X-3,90$ & 210.80 & 144.2 & 144.2 & 50.9 & 17.3 & $0-25$ & $7.32 \mathrm{E}-04$ & & & \\
\hline $23 X-5,90$ & 213.80 & 24.7 & 24.7 & 10.6 & 13.2 & $10-30$ & $5.46 \mathrm{E}-04$ & & & \\
\hline $24 X-2,77$ & 216.77 & 94.0 & 94.0 & 13.0 & 29.9 & $0-35$ & $1.26 \mathrm{E}-03$ & & & \\
\hline $24 X-3,83$ & 218.33 & 25.8 & 25.8 & 1.2 & 14.4 & $5-30$ & $6.91 \mathrm{E}-04$ & & & \\
\hline $24 X-5,98$ & 221.48 & NA & & NA & NA & NA & $7.23 \mathrm{E}-04$ & & & \\
\hline $24 X-7,30$ & 223.80 & 214.3 & 214.3 & 3.2 & 17.7 & $30-60$ & $4.48 \mathrm{E}-04$ & & & \\
\hline $25 X-1,95$ & 225.05 & 164.0 & 164.0 & -2.1 & 13.6 & $20-50$ & $1.06 \mathrm{E}-03$ & & & \\
\hline $25 X-3,101$ & 228.11 & 328.4 & 328.4 & -12.2 & 14.9 & $5-25$ & $1.38 \mathrm{E}-03$ & & & \\
\hline $25 X-5,85$ & 230.95 & 56.7 & 56.7 & -5.9 & 32.1 & $0-60$ & $5.81 \mathrm{E}-04$ & & & \\
\hline $26 X-1,73$ & 234.33 & 178.3 & 178.3 & -12.1 & 7.4 & $20-40$ & $1.67 \mathrm{E}-03$ & & & \\
\hline $26 X-3,113$ & 237.73 & 200.7 & 200.7 & -4.1 & 9.1 & $30-60$ & $1.14 \mathrm{E}-03$ & & & \\
\hline $26 X-5,91$ & 240.51 & 357.1 & 357.1 & 5.7 & 11.4 & $10-30$ & $4.16 \mathrm{E}-04$ & & & \\
\hline $28 X-1,130$ & 254.10 & 264.8 & 264.8 & -17.9 & 24.1 & $10-50$ & $1.65 \mathrm{E}-03$ & & & \\
\hline $28 X-3,78$ & 256.58 & 301.2 & 301.2 & -8.3 & 10.3 & $20-40$ & $2.32 \mathrm{E}-03$ & & & \\
\hline $28 X-5,76$ & 259.56 & 280.2 & 280.2 & -17.6 & 20.7 & $10-60$ & $1.51 \mathrm{E}-03$ & & & \\
\hline $29 X-1,95$ & 263.35 & 131.9 & 131.9 & -58.3 & 19.9 & $10-60$ & $1.42 \mathrm{E}-03$ & & & \\
\hline $29 X-3,106$ & 264.97 & NA & & NA & NA & NA & $1.62 \mathrm{E}-03$ & & & \\
\hline $29 X-5,104$ & 267.95 & 193.7 & 193.7 & -7.4 & 8.7 & $10-30$ & 2.07E-03 & & & \\
\hline $29 X-7,124$ & 270.81 & 349.2 & 349.2 & -12.5 & 12.5 & $10-40$ & $1.61 \mathrm{E}-03$ & & & \\
\hline $30 X-1,114$ & 273.24 & 47.3 & 47.3 & -4.6 & 13.2 & $10-30$ & $1.60 \mathrm{E}-03$ & & & \\
\hline $30 x-3,95$ & 276.05 & 2.4 & 2.4 & -10.9 & 8.6 & $10-30$ & $8.75 \mathrm{E}-04$ & & & \\
\hline $30 \times-5,90$ & 279.00 & 236.7 & 236.7 & -13.1 & 4.6 & $10-35$ & $2.50 \mathrm{E}-03$ & & & \\
\hline $30 x-7,55$ & 281.15 & NA & & NA & NA & NA & $9.89 \mathrm{E}-04$ & & & \\
\hline
\end{tabular}

Notes: $\mathrm{MAD}=$ maximum angular deviation, $\mathrm{NRM}=$ natural remanent magnetization. $\mathrm{NA}=$ not applicable. 
Table T21. Magnetic susceptibility of discrete samples, Hole U1334A. (See table notes.) (Continued on next two pages.)

\begin{tabular}{|c|c|c|c|c|c|c|c|c|c|c|c|}
\hline \multirow[b]{2}{*}{$\begin{array}{l}\text { Core, section, } \\
\text { interval }(\mathrm{cm})\end{array}$} & \multirow[b]{2}{*}{$\begin{array}{l}\text { Depth } \\
\operatorname{CSF}(\mathrm{m})\end{array}$} & \multirow[b]{2}{*}{ LIMS ID } & & \multirow[b]{2}{*}{$\begin{array}{l}\text { Total } \\
\text { mass } \\
(\mathrm{g})\end{array}$} & \multirow[b]{2}{*}{$\begin{array}{c}\text { Bulk } \\
\text { density } \\
\left(\mathrm{g} / \mathrm{cm}^{3}\right)\end{array}$} & \multirow[b]{2}{*}{$\begin{array}{l}\text { Volume } \\
\left(\mathrm{cm}^{3}\right)\end{array}$} & \multicolumn{3}{|c|}{ Susceptibility } & \multirow[b]{2}{*}{$\begin{array}{l}\text { Scale } \\
\text { factor }\end{array}$} \\
\hline & & & $\begin{array}{c}\text { Susce } \\
\text { Raw } \\
\left(10^{-6}\right)\end{array}$ & 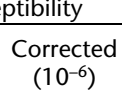 & & & & $\begin{array}{c}\text { Volume } \\
\text { normalized } \\
\left(10^{-5}\right)\end{array}$ & $\begin{array}{c}\text { Mass } \\
\text { normalized } \\
\left(\mathrm{m}^{3} / \mathrm{kg}\right)\end{array}$ & $\begin{array}{l}\text { Whole core } \\
\text { (raw values) }\end{array}$ & \\
\hline 320-U1334A- & & & & & & & & & & & \\
\hline $1 \mathrm{H}-1,84-86$ & 0.85 & CUBE653331 & 127.1 & 132.0 & 10.43 & 1.19 & 4.90 & 18.86 & $8.859 \mathrm{E}-08$ & 23.43 & $8.05 \mathrm{E}-01$ \\
\hline $1 \mathrm{H}-2,84-86$ & 2.35 & CUBE653351 & 59.4 & 64.3 & 7.84 & 1.21 & 2.67 & 16.83 & $5.741 \mathrm{E}-08$ & 23.23 & $7.24 \mathrm{E}-01$ \\
\hline $1 \mathrm{H}-3,84-86$ & 3.85 & CUBE653361 & 236.0 & 240.9 & 12.38 & 1.16 & 6.74 & 25.02 & $1.362 \mathrm{E}-07$ & 31.63 & $7.91 \mathrm{E}-01$ \\
\hline $1 \mathrm{H}-4,84-86$ & 5.35 & CUBE653371 & 181.5 & 186.4 & 11.10 & 1.22 & 5.35 & 24.41 & $1.175 \mathrm{E}-07$ & 33.20 & $7.35 \mathrm{E}-01$ \\
\hline $1 \mathrm{H}-5,84-86$ & 6.85 & CUBE653381 & 158.9 & 163.8 & 11.36 & 1.18 & 5.74 & 19.97 & $1.009 \mathrm{E}-07$ & 27.92 & $7.15 \mathrm{E}-01$ \\
\hline $1 \mathrm{H}-6,39-41$ & 7.90 & CUBE653341 & 166.5 & 171.4 & 12.30 & 1.20 & 6.40 & 18.73 & $9.754 \mathrm{E}-08$ & 23.01 & $8.14 \mathrm{E}-01$ \\
\hline $2 \mathrm{H}-1,84-86$ & 9.05 & CUBE655331 & 151.8 & 156.7 & 11.82 & 1.18 & 6.11 & 17.94 & $9.280 \mathrm{E}-08$ & 24.48 & 7.33E-01 \\
\hline $2 \mathrm{H}-2,84-86$ & 10.55 & CUBE655341 & 198.9 & 203.8 & 12.16 & 1.14 & 6.64 & 21.47 & $1.173 \mathrm{E}-07$ & 29.49 & $7.28 \mathrm{E}-01$ \\
\hline $2 \mathrm{H}-3,84-86$ & 12.05 & CUBE655351 & 209.5 & 214.4 & 11.59 & 1.20 & 5.83 & 25.74 & $1.295 \mathrm{E}-07$ & 35.65 & $7.22 \mathrm{E}-01$ \\
\hline $2 \mathrm{H}-4,84-86$ & 13.55 & CUBE655361 & 182.4 & 187.3 & 11.78 & 1.20 & 5.99 & 21.89 & $1.113 \mathrm{E}-07$ & 30.91 & $7.08 \mathrm{E}-01$ \\
\hline $2 \mathrm{H}-5,84-86$ & 15.05 & CUBE655371 & 174.4 & 179.3 & 11.51 & 1.20 & 5.76 & 21.77 & $1.090 \mathrm{E}-07$ & 31.02 & $7.02 \mathrm{E}-01$ \\
\hline $2 \mathrm{H}-6,84-86$ & 16.55 & CUBE655381 & 158.9 & 163.8 & 12.03 & 1.20 & 6.20 & 18.50 & $9.531 \mathrm{E}-08$ & 24.71 & $7.48 \mathrm{E}-01$ \\
\hline $2 \mathrm{H}-7,49-51$ & 17.70 & CUBE655391 & 109.5 & 114.4 & 12.75 & 1.42 & 5.74 & 13.95 & $6.281 \mathrm{E}-08$ & 17.21 & $8.10 \mathrm{E}-01$ \\
\hline $3 \mathrm{H}-1,84-86$ & 18.55 & CUBE655901 & 193.4 & 198.3 & 12.32 & 1.24 & 6.25 & 22.21 & 1.127E-07 & 28.90 & $7.68 \mathrm{E}-01$ \\
\hline $3 \mathrm{H}-2,84-86$ & 20.05 & CUBE655911 & 194.5 & 199.4 & 11.63 & 1.21 & 5.83 & 23.93 & $1.200 \mathrm{E}-07$ & 28.32 & $8.45 \mathrm{E}-01$ \\
\hline $3 \mathrm{H}-3,84-86$ & 21.55 & CUBE655921 & 175.2 & 180.1 & 12.50 & 1.25 & 6.34 & 19.88 & $1.009 \mathrm{E}-07$ & 24.40 & $8.15 \mathrm{E}-01$ \\
\hline $3 \mathrm{H}-4,84-86$ & 23.05 & CUBE655931 & 211.8 & 216.7 & 12.08 & 1.34 & 5.59 & 27.16 & $1.256 \mathrm{E}-07$ & 32.64 & $8.32 \mathrm{E}-01$ \\
\hline $3 \mathrm{H}-5,84-86$ & 24.55 & CUBE655941 & 287.3 & 292.2 & 12.04 & 1.22 & 6.11 & 33.48 & $1.699 \mathrm{E}-07$ & 39.85 & $8.40 \mathrm{E}-01$ \\
\hline $3 \mathrm{H}-6,84-86$ & 26.05 & CUBE655951 & 242.2 & 247.1 & 12.42 & 1.22 & 6.39 & 27.06 & $1.393 \mathrm{E}-07$ & 35.52 & $7.62 \mathrm{E}-01$ \\
\hline $3 \mathrm{H}-7,49-51$ & 27.20 & CUBE655961 & 231.3 & 236.2 & 12.17 & 1.31 & 5.77 & 28.63 & $1.359 \mathrm{E}-07$ & 28.77 & $9.95 \mathrm{E}-01$ \\
\hline $4 \mathrm{H}-1,84-86$ & 28.05 & CUBE657671 & 85.4 & 90.3 & 13.25 & 1.30 & 6.64 & 9.52 & $4.770 \mathrm{E}-08$ & 18.62 & $5.11 \mathrm{E}-01$ \\
\hline $4 \mathrm{H}-2,84-86$ & 29.55 & CUBE657681 & 69.1 & 74.0 & 13.35 & 1.42 & 6.17 & 8.40 & $3.882 \mathrm{E}-08$ & 16.07 & $5.22 \mathrm{E}-01$ \\
\hline $4 \mathrm{H}-3,84-86$ & 31.05 & CUBE657691 & 165.2 & 170.1 & 12.40 & 1.20 & 6.51 & 18.30 & $9.602 \mathrm{E}-08$ & 26.08 & $7.02 \mathrm{E}-01$ \\
\hline $4 \mathrm{H}-4,84-86$ & 32.55 & CUBE657701 & 106.9 & 111.8 & 13.49 & 1.29 & 6.91 & 11.32 & $5.801 \mathrm{E}-08$ & 24.56 & $4.61 \mathrm{E}-01$ \\
\hline $4 \mathrm{H}-5,84-86$ & 34.05 & CUBE657711 & 122.8 & 127.7 & 13.39 & 1.53 & 5.74 & 15.56 & $6.676 \mathrm{E}-08$ & 25.95 & $6.00 \mathrm{E}-01$ \\
\hline $4 \mathrm{H}-6,84-86$ & 35.55 & CUBE657721 & 264.4 & 269.3 & 11.80 & 1.20 & 6.00 & 31.40 & $1.598 \mathrm{E}-07$ & 36.80 & $8.53 \mathrm{E}-01$ \\
\hline $4 \mathrm{H}-7,49-51$ & 36.70 & CUBE657731 & 209.5 & 214.4 & 11.95 & 1.22 & 6.01 & 24.97 & $1.256 \mathrm{E}-07$ & 31.37 & 7.96E-01 \\
\hline $5 \mathrm{H}-1,84-86$ & 37.55 & CUBE659081 & 153.6 & 158.5 & 12.36 & 1.28 & 6.05 & 18.33 & 8.977E-08 & 27.12 & $6.76 \mathrm{E}-01$ \\
\hline $5 \mathrm{H}-2,84-86$ & 39.05 & CUBE659091 & 228.7 & 233.6 & 12.47 & 1.29 & 6.10 & 26.81 & $1.311 \mathrm{E}-07$ & 32.36 & $8.28 \mathrm{E}-01$ \\
\hline $5 \mathrm{H}-3,84-86$ & 40.55 & CUBE659101 & 190.3 & 195.2 & 12.62 & 1.24 & 6.46 & 21.14 & $1.083 \mathrm{E}-07$ & 28.46 & $7.43 \mathrm{E}-01$ \\
\hline $5 \mathrm{H}-4,84-86$ & 42.05 & CUBE659111 & 170.6 & 175.5 & 12.05 & 1.27 & 5.89 & 20.86 & $1.020 \mathrm{E}-07$ & 26.89 & 7.76E-01 \\
\hline $5 \mathrm{H}-5,84-86$ & 43.55 & CUBE659121 & 193.8 & 198.7 & 12.89 & 1.37 & 6.04 & 23.04 & $1.079 \mathrm{E}-07$ & 26.63 & $8.65 \mathrm{E}-01$ \\
\hline $5 \mathrm{H}-6,84-86$ & 45.05 & CUBE659131 & 165.0 & 169.9 & 12.91 & 1.22 & 6.84 & 17.40 & $9.212 \mathrm{E}-08$ & 24.83 & 7.01E-01 \\
\hline $5 \mathrm{H}-7,74-76$ & 46.45 & CUBE659141 & 77.9 & 82.8 & 14.09 & 1.44 & 6.60 & 8.78 & $4.113 \mathrm{E}-08$ & 15.41 & $5.69 \mathrm{E}-01$ \\
\hline $6 \mathrm{H}-1,84-86$ & 47.05 & CUBE660361 & 49.9 & 54.8 & 13.12 & 1.58 & 5.41 & 7.09 & $2.923 \mathrm{E}-08$ & 8.08 & 8.77E-01 \\
\hline $6 \mathrm{H}-2,84-86$ & 48.55 & CUBE660381 & 28.9 & 33.8 & 14.84 & 1.52 & 6.72 & 3.52 & $1.593 \mathrm{E}-08$ & 7.03 & $5.00 \mathrm{E}-01$ \\
\hline $6 \mathrm{H}-3,84-86$ & 50.05 & CUBE660391 & 28.9 & 33.8 & 14.83 & 1.64 & 6.22 & 3.81 & 1.597E-08 & 7.20 & $5.29 \mathrm{E}-01$ \\
\hline $6 \mathrm{H}-4,84-86$ & 51.55 & CUBE660401 & 34.6 & 39.5 & 13.56 & 1.61 & 5.56 & 4.98 & 2.040E-08 & 7.82 & 6.36E-01 \\
\hline $6 \mathrm{H}-5,84-86$ & 53.05 & CUBE660411 & 29.6 & 34.5 & 12.70 & 1.57 & 5.17 & 4.67 & $1.901 \mathrm{E}-08$ & 9.51 & $4.91 \mathrm{E}-01$ \\
\hline $6 \mathrm{H}-6,84-86$ & 54.55 & CUBE660421 & 136.1 & 141.0 & 12.25 & 1.38 & 5.56 & 17.76 & 8.057E-08 & 21.68 & $8.19 \mathrm{E}-01$ \\
\hline $6 \mathrm{H}-7,64-66$ & 55.85 & CUBE660371 & 126.8 & 131.7 & 11.86 & 1.46 & 4.98 & 18.51 & 7.773E-08 & 19.61 & $9.44 \mathrm{E}-01$ \\
\hline 7H-1, 119-121 & 56.90 & CUBE661671 & 83.8 & 88.7 & 13.07 & 1.38 & 6.14 & 10.11 & $4.751 \mathrm{E}-08$ & 14.84 & $6.81 \mathrm{E}-01$ \\
\hline 7H-2, 84-86 & 58.05 & CUBE661681 & 165.4 & 170.3 & 13.05 & 1.45 & 5.85 & 20.39 & $9.135 \mathrm{E}-08$ & 21.09 & 9.67E-01 \\
\hline $7 \mathrm{H}-3,84-86$ & 59.55 & CUBE661701 & 82.4 & 87.3 & 14.09 & 1.53 & 6.22 & 9.83 & $4.338 \mathrm{E}-08$ & 11.13 & $8.83 \mathrm{E}-01$ \\
\hline $7 \mathrm{H}-4,84-86$ & 61.05 & CUBE661711 & 29.4 & 34.3 & 14.88 & 1.62 & 6.34 & 3.79 & $1.614 \mathrm{E}-08$ & 7.87 & $4.81 \mathrm{E}-01$ \\
\hline 7H-5, 84-86 & 62.55 & CUBE661721 & 67.7 & 72.6 & 13.82 & 1.31 & 7.03 & 7.23 & $3.678 \mathrm{E}-08$ & 15.69 & $4.61 \mathrm{E}-01$ \\
\hline $7 \mathrm{H}-6,84-86$ & 64.05 & CUBE661731 & 38.4 & 43.3 & 14.45 & 1.57 & 6.27 & 4.83 & $2.095 \mathrm{E}-08$ & 10.75 & $4.49 \mathrm{E}-01$ \\
\hline 7H-7, 59-61 & 65.30 & CUBE661691 & 9.7 & 14.6 & 14.55 & 1.72 & 5.80 & 1.76 & 7.007E-09 & 4.59 & $3.83 \mathrm{E}-01$ \\
\hline $8 \mathrm{H}-1,129-131$ & 66.50 & CUBE662461 & 32.4 & 37.3 & 13.79 & 1.41 & 6.51 & 4.01 & $1.893 \mathrm{E}-08$ & 8.07 & 4.96E-01 \\
\hline $8 \mathrm{H}-2,84-86$ & 67.55 & CUBE662471 & 38.8 & 43.7 & 13.84 & 1.50 & 6.16 & 4.97 & $2.209 \mathrm{E}-08$ & 8.79 & 5.65E-01 \\
\hline $8 \mathrm{H}-3,84-86$ & 69.05 & CUBE662481 & 18.8 & 23.7 & 14.71 & 1.46 & 6.93 & 2.40 & $1.129 \mathrm{E}-08$ & 6.55 & $3.66 \mathrm{E}-01$ \\
\hline $8 \mathrm{H}-4,84-86$ & 70.55 & CUBE662491 & 23.7 & 28.6 & 15.20 & 1.51 & 7.05 & 2.84 & $1.316 \mathrm{E}-08$ & 7.12 & $3.99 \mathrm{E}-01$ \\
\hline $8 \mathrm{H}-5,84-86$ & 72.05 & CUBE662501 & 26.7 & 31.6 & 14.83 & 1.71 & 5.98 & 3.70 & $1.493 \mathrm{E}-08$ & 6.04 & $6.13 \mathrm{E}-01$ \\
\hline $8 \mathrm{H}-6,84-86$ & 73.55 & CUBE662511 & 29.0 & 33.9 & 14.75 & 1.60 & 6.37 & 3.73 & $1.610 \mathrm{E}-08$ & 6.80 & $5.48 \mathrm{E}-01$ \\
\hline $8 \mathrm{H}-7,54-56$ & 74.75 & CUBE662521 & 29.0 & 33.9 & 14.45 & 1.49 & 6.62 & 3.58 & $1.642 \mathrm{E}-08$ & 6.49 & $5.52 \mathrm{E}-01$ \\
\hline $9 \mathrm{H}-1,84-86$ & 75.55 & CUBE663541 & 49.8 & 54.7 & 14.71 & 1.54 & 6.55 & 5.84 & $2.602 \mathrm{E}-08$ & 6.63 & $8.81 \mathrm{E}-01$ \\
\hline $9 \mathrm{H}-2,84-86$ & 77.05 & CUBE663551 & 41.7 & 46.6 & 13.66 & 1.55 & 5.84 & 5.59 & $2.390 \mathrm{E}-08$ & 7.18 & $7.79 \mathrm{E}-01$ \\
\hline $9 \mathrm{H}-3,84-86$ & 78.55 & CUBE663561 & 87.9 & 92.8 & 13.82 & 1.50 & 6.15 & 10.56 & $4.698 \mathrm{E}-08$ & 11.37 & $9.29 \mathrm{E}-01$ \\
\hline $9 \mathrm{H}-4,84-86$ & 80.05 & CUBE663571 & 26.8 & 31.7 & 13.33 & 1.42 & 6.15 & 3.61 & $1.665 \mathrm{E}-08$ & 8.44 & $4.28 \mathrm{E}-01$ \\
\hline $9 \mathrm{H}-5,84-86$ & 81.55 & CUBE663581 & 31.5 & 36.4 & 13.98 & 1.62 & 5.80 & 4.39 & $1.823 \mathrm{E}-08$ & 3.75 & 1.17E+00 \\
\hline $9 \mathrm{H}-6,84-86$ & 83.05 & CUBE663591 & 23.5 & 28.4 & 13.96 & 1.71 & 5.47 & 3.63 & 1.422E-08 & 3.68 & $9.87 \mathrm{E}-01$ \\
\hline $9 \mathrm{H}-7,74-76$ & 84.45 & CUBE663601 & 97.3 & 102.2 & 13.72 & 1.55 & 5.90 & 12.13 & $5.214 \mathrm{E}-08$ & 9.41 & $1.29 \mathrm{E}+00$ \\
\hline $10 \mathrm{H}-1,89-91$ & 85.10 & CUBE664681 & 35.8 & 40.7 & 13.45 & 1.54 & 5.75 & 4.95 & $2.119 \mathrm{E}-08$ & 9.79 & $5.06 \mathrm{E}-01$ \\
\hline $10 \mathrm{H}-2,84-86$ & 86.55 & CUBE664691 & 26.3 & 31.2 & 13.15 & 1.61 & 5.30 & 4.12 & $1.662 \mathrm{E}-08$ & 9.02 & 4.57E-01 \\
\hline $10 \mathrm{H}-3,84-86$ & 88.05 & CUBE664701 & 80.9 & 85.8 & 13.23 & 1.45 & 5.97 & 10.06 & $4.538 \mathrm{E}-08$ & 14.37 & $7.00 \mathrm{E}-01$ \\
\hline
\end{tabular}


Table T21 (continued). (Continued on next page.)

\begin{tabular}{|c|c|c|c|c|c|c|c|c|c|c|c|}
\hline \multirow[b]{3}{*}{$\begin{array}{l}\text { Core, section, } \\
\text { interval }(\mathrm{cm})\end{array}$} & \multirow[b]{3}{*}{$\begin{array}{l}\text { Depth } \\
\text { CSF }(m)\end{array}$} & \multirow[b]{3}{*}{ LIMS ID } & \multirow{2}{*}{\multicolumn{2}{|c|}{ Susceptibility }} & \multirow{3}{*}{$\begin{array}{l}\text { Total } \\
\text { mass } \\
(\mathrm{g})\end{array}$} & \multirow{3}{*}{$\begin{array}{c}\text { Bulk } \\
\text { density } \\
\left(\mathrm{g} / \mathrm{cm}^{3}\right)\end{array}$} & \multirow[b]{3}{*}{$\begin{array}{l}\text { Volume } \\
\left(\mathrm{cm}^{3}\right)\end{array}$} & \multicolumn{3}{|c|}{ Susceptibility } & \\
\hline & & & & & & & & & & & \\
\hline & & & $\begin{array}{l}\text { Raw } \\
\left(10^{-6}\right)\end{array}$ & $\begin{array}{c}\text { Corrected } \\
\left(10^{-6}\right)\end{array}$ & & & & $\begin{array}{c}\text { normalized } \\
\left(10^{-5}\right)\end{array}$ & $\begin{array}{c}\text { normalized } \\
\left(\mathrm{m}^{3} / \mathrm{kg}\right)\end{array}$ & $\begin{array}{l}\text { Whole core } \\
\text { (raw values) }\end{array}$ & $\begin{array}{l}\text { Scale } \\
\text { factor }\end{array}$ \\
\hline $10 \mathrm{H}-4,84-86$ & 89.55 & CUBE664711 & 44.3 & 49.2 & 14.14 & 1.50 & 6.37 & 5.40 & $2.433 \mathrm{E}-08$ & 10.77 & $5.02 \mathrm{E}-01$ \\
\hline $10 \mathrm{H}-5,84-86$ & 91.05 & CUBE664721 & 40.5 & 45.4 & 14.17 & 1.57 & 6.09 & 5.22 & $2.241 \mathrm{E}-08$ & 7.44 & 7.01E-01 \\
\hline $10 \mathrm{H}-6,84-86$ & 92.55 & CUBE664731 & 32.7 & 37.6 & 13.61 & 1.62 & 5.56 & 4.73 & $1.933 \mathrm{E}-08$ & 6.25 & 7.57E-01 \\
\hline $10 \mathrm{H}-7,39-41$ & 93.60 & CUBE664741 & 25.9 & 30.8 & 13.67 & 1.65 & 5.52 & 3.91 & 1.577E-08 & 4.87 & $8.02 \mathrm{E}-01$ \\
\hline $11 \mathrm{H}-1,89-91$ & 94.60 & CUBE665311 & 42.8 & 47.7 & 14.76 & 1.47 & 6.93 & 4.82 & $2.263 \mathrm{E}-08$ & 8.04 & $5.99 \mathrm{E}-01$ \\
\hline $11 \mathrm{H}-2,84-86$ & 96.05 & CUBE665321 & 30.5 & 35.4 & 14.85 & 1.73 & 5.95 & 4.17 & $1.671 \mathrm{E}-08$ & 6.87 & $6.07 \mathrm{E}-01$ \\
\hline $11 \mathrm{H}-3,84-86$ & 97.55 & CUBE665331 & 56.4 & 61.3 & 14.33 & 1.61 & 6.05 & 7.10 & $2.996 \mathrm{E}-08$ & 9.20 & $7.71 \mathrm{E}-01$ \\
\hline $11 \mathrm{H}-4,84-86$ & 99.05 & CUBE665341 & 47.3 & 52.2 & 13.82 & 1.56 & 5.90 & 6.19 & $2.645 \mathrm{E}-08$ & 7.35 & $8.43 \mathrm{E}-01$ \\
\hline $11 \mathrm{H}-5,84-86$ & 100.55 & CUBE665351 & 38.6 & 43.5 & 14.62 & 1.68 & 5.97 & 5.10 & $2.080 \mathrm{E}-08$ & 6.75 & $7.55 \mathrm{E}-01$ \\
\hline $11 \mathrm{H}-6,84-86$ & 102.05 & CUBE665361 & 36.1 & 41.0 & 9.08 & 1.60 & 2.80 & 10.25 & $3.160 \mathrm{E}-08$ & 13.19 & 7.77E-01 \\
\hline $11 \mathrm{H}-7,49-51$ & 103.20 & CUBE665371 & 115.6 & 120.5 & 13.53 & 1.53 & 5.82 & 14.48 & $6.234 \mathrm{E}-08$ & 16.78 & $8.63 \mathrm{E}-01$ \\
\hline $12 \mathrm{H}-1,84-86$ & 104.05 & CUBE665781 & 47.2 & 52.1 & 14.62 & 1.60 & 6.26 & 5.83 & $2.496 \mathrm{E}-08$ & 8.46 & $6.89 \mathrm{E}-01$ \\
\hline $12 \mathrm{H}-2,84-86$ & 105.55 & CUBE665791 & 57.3 & 62.2 & 14.65 & 2.06 & 4.89 & 8.91 & $2.970 \mathrm{E}-08$ & 9.07 & $9.82 \mathrm{E}-01$ \\
\hline $12 \mathrm{H}-3,84-86$ & 107.05 & CUBE665801 & 57.6 & 62.5 & 14.27 & 1.59 & 6.08 & 7.20 & $3.066 \mathrm{E}-08$ & 8.33 & $8.64 \mathrm{E}-01$ \\
\hline $12 \mathrm{H}-4,84-86$ & 108.55 & CUBE665811 & 85.5 & 90.4 & 14.46 & 1.58 & 6.24 & 10.13 & $4.374 \mathrm{E}-08$ & 10.99 & $9.22 \mathrm{E}-01$ \\
\hline $12 \mathrm{H}-5,84-86$ & 110.05 & CUBE665821 & 62.2 & 67.1 & 14.04 & 1.66 & 5.70 & 8.24 & $3.345 \mathrm{E}-08$ & 8.60 & $9.58 \mathrm{E}-01$ \\
\hline $12 \mathrm{H}-6,84-86$ & 111.55 & CUBE665831 & 59.4 & 64.3 & 13.77 & 1.65 & 5.56 & 8.10 & 3.267E-08 & 8.04 & $1.01 \mathrm{E}+00$ \\
\hline $12 \mathrm{H}-7,39-41$ & 112.37 & CUBE665841 & 61.8 & 66.7 & 14.23 & 1.55 & 6.22 & 7.50 & $3.279 \mathrm{E}-08$ & 8.76 & $8.56 \mathrm{E}-01$ \\
\hline $13 \mathrm{H}-2,84-86$ & 114.05 & CUBE666811 & 57.5 & 62.4 & 13.85 & 1.64 & 5.64 & 7.75 & $3.153 \mathrm{E}-08$ & 8.77 & $8.84 \mathrm{E}-01$ \\
\hline $13 \mathrm{H}-3,84-86$ & 115.55 & CUBE666821 & 47.3 & 52.2 & 13.56 & 1.62 & 5.53 & 6.61 & $2.694 \mathrm{E}-08$ & 6.79 & $9.74 \mathrm{E}-01$ \\
\hline $13 \mathrm{H}-4,84-86$ & 117.05 & CUBE666831 & 107.4 & 112.3 & 13.92 & 1.44 & 6.48 & 12.12 & 5.647E-08 & 12.77 & $9.49 \mathrm{E}-01$ \\
\hline $13 \mathrm{H}-5,84-86$ & 118.55 & CUBE666841 & 49.5 & 54.4 & 13.40 & 1.37 & 6.45 & 5.91 & $2.842 \mathrm{E}-08$ & 9.29 & $6.36 \mathrm{E}-01$ \\
\hline $13 \mathrm{H}-6,84-86$ & 120.05 & CUBE666851 & 33.6 & 38.5 & 14.97 & 1.72 & 6.04 & 4.47 & $1.802 \mathrm{E}-08$ & 5.37 & $8.31 \mathrm{E}-01$ \\
\hline $13 \mathrm{H}-7,84-86$ & 121.55 & CUBE666861 & 43.1 & 48.0 & 14.38 & 1.67 & 5.87 & 5.73 & $2.336 \mathrm{E}-08$ & 7.03 & $8.15 \mathrm{E}-01$ \\
\hline $13 \mathrm{H}-8,49-51$ & 122.20 & CUBE666871 & 44.1 & 49.0 & 13.87 & 1.52 & 6.11 & 5.61 & $2.474 \mathrm{E}-08$ & 7.74 & $7.25 \mathrm{E}-01$ \\
\hline $14 \mathrm{H}-1,84-86$ & 123.05 & CUBE667411 & 85.7 & 90.6 & 12.18 & 1.58 & 4.81 & 13.19 & $5.205 \mathrm{E}-08$ & 12.93 & $1.02 \mathrm{E}+00$ \\
\hline $14 \mathrm{H}-2,84-86$ & 124.55 & CUBE667421 & 50.9 & 55.8 & 15.07 & 1.60 & 6.54 & 5.96 & $2.590 \mathrm{E}-08$ & 6.13 & $9.74 \mathrm{E}-01$ \\
\hline $14 \mathrm{H}-3,84-86$ & 126.05 & CUBE667431 & 55.2 & 60.1 & 13.92 & 1.57 & 5.95 & 7.07 & $3.024 \mathrm{E}-08$ & 4.44 & $1.59 \mathrm{E}+00$ \\
\hline $14 \mathrm{H}-4,84-86$ & 127.55 & CUBE667441 & 94.7 & 99.6 & 13.29 & 1.50 & 5.81 & 11.99 & $5.244 \mathrm{E}-08$ & 8.94 & $1.34 \mathrm{E}+00$ \\
\hline $14 \mathrm{H}-5,84-86$ & 129.05 & CUBE667451 & 100.6 & 105.5 & 14.31 & 1.68 & 5.79 & 12.75 & $5.161 \mathrm{E}-08$ & 8.00 & $1.59 \mathrm{E}+00$ \\
\hline $14 \mathrm{H}-6,84-86$ & 130.55 & CUBE667461 & 54.4 & 59.3 & 14.12 & 1.65 & 5.78 & 7.19 & $2.941 \mathrm{E}-08$ & 4.14 & $1.73 \mathrm{E}+00$ \\
\hline $15 \mathrm{H}-1,94-96$ & 132.65 & CUBE668491 & 34.9 & 39.8 & 14.44 & 1.66 & 5.94 & 4.69 & $1.929 \mathrm{E}-08$ & 6.32 & $7.42 \mathrm{E}-01$ \\
\hline $15 \mathrm{H}-2,84-86$ & 134.05 & CUBE668501 & 28.5 & 33.4 & 12.79 & 1.64 & 4.99 & 4.69 & $1.830 \mathrm{E}-08$ & 7.33 & $6.40 \mathrm{E}-01$ \\
\hline $15 \mathrm{H}-3,84-86$ & 135.55 & CUBE668511 & 44.1 & 49.0 & 15.03 & 1.59 & 6.57 & 5.22 & $2.283 \mathrm{E}-08$ & 8.23 & $6.35 \mathrm{E}-01$ \\
\hline $15 \mathrm{H}-4,84-86$ & 137.05 & CUBE668521 & 7.2 & 12.1 & 14.18 & 1.59 & 6.02 & 1.41 & 5.967E-09 & 4.90 & $2.86 \mathrm{E}-01$ \\
\hline $15 \mathrm{H}-5,84-86$ & 138.55 & CUBE668531 & 3.2 & 8.1 & 15.46 & 1.66 & 6.56 & 0.87 & $3.674 \mathrm{E}-09$ & 4.19 & $2.06 \mathrm{E}-01$ \\
\hline $15 \mathrm{H}-6,64-66$ & 139.85 & CUBE668541 & 9.3 & 14.2 & 14.24 & 1.75 & 5.52 & 1.81 & $6.993 \mathrm{E}-09$ & 3.35 & $5.39 \mathrm{E}-01$ \\
\hline $16 \mathrm{H}-1,94-96$ & 142.15 & CUBE669761 & 2.1 & 7.0 & 14.29 & 1.61 & 6.01 & 0.81 & $3.416 \mathrm{E}-09$ & 1.86 & 4.37E-01 \\
\hline $16 \mathrm{H}-2,84-86$ & 143.55 & CUBE669771 & -3.7 & 1.2 & 13.33 & 1.82 & 4.80 & 0.17 & $6.128 \mathrm{E}-10$ & 1.49 & $1.14 \mathrm{E}-01$ \\
\hline $16 \mathrm{H}-3,84-86$ & 145.05 & CUBE669781 & -1.0 & 3.9 & 14.59 & 1.77 & 5.66 & 0.48 & $1.860 \mathrm{E}-09$ & 2.19 & $2.19 \mathrm{E}-01$ \\
\hline $16 \mathrm{H}-4,84-86$ & 146.55 & CUBE669791 & -0.9 & 4.0 & 14.83 & 1.67 & 6.13 & 0.46 & 1.907E-09 & 2.19 & $2.10 \mathrm{E}-01$ \\
\hline $16 \mathrm{H}-5,84-86$ & 148.05 & CUBE669801 & -2.4 & 2.5 & 14.66 & 1.70 & 5.92 & 0.29 & 1.177E-09 & 2.46 & $1.19 \mathrm{E}-01$ \\
\hline $16 \mathrm{H}-6,54-56$ & 149.25 & CUBE669811 & -0.7 & 4.2 & 14.60 & 1.85 & 5.42 & 0.54 & $2.010 \mathrm{E}-09$ & 1.76 & $3.08 \mathrm{E}-01$ \\
\hline $17 \mathrm{H}-1,84-86$ & 151.55 & CUBE670691 & 0.3 & 5.2 & 14.94 & 1.70 & 6.07 & 0.60 & $2.428 \mathrm{E}-09$ & 0.82 & $7.33 \mathrm{E}-01$ \\
\hline $17 \mathrm{H}-2,84-86$ & 153.05 & CUBE670701 & 3.1 & 8.0 & 14.63 & 1.68 & 5.98 & 0.94 & $3.831 \mathrm{E}-09$ & 0.64 & $1.46 \mathrm{E}+00$ \\
\hline $17 \mathrm{H}-3,84-86$ & 154.55 & CUBE670711 & -0.6 & 4.3 & 14.77 & 1.73 & 5.87 & 0.52 & $2.060 \mathrm{E}-09$ & 1.07 & $4.85 \mathrm{E}-01$ \\
\hline $17 \mathrm{H}-4,84-86$ & 156.05 & CUBE670721 & 5.5 & 10.4 & 11.85 & 1.68 & 4.32 & 1.69 & $6.152 \mathrm{E}-09$ & 2.71 & $6.22 \mathrm{E}-01$ \\
\hline $17 \mathrm{H}-5,84-86$ & 157.55 & CUBE670731 & 5.4 & 10.3 & 13.30 & 1.64 & 5.30 & 1.36 & $5.414 \mathrm{E}-09$ & 2.55 & $5.32 \mathrm{E}-01$ \\
\hline $17 \mathrm{H}-6,64-66$ & 158.85 & CUBE670741 & 3.2 & 8.1 & 14.89 & 1.75 & 5.90 & 0.96 & $3.789 \mathrm{E}-09$ & 2.02 & $4.72 \mathrm{E}-01$ \\
\hline $18 \mathrm{H}-2,84-86$ & 162.55 & CUBE671281 & 1.1 & 6.0 & 15.91 & 1.64 & 6.89 & 0.61 & $2.635 \mathrm{E}-09$ & 1.90 & $3.21 \mathrm{E}-01$ \\
\hline $18 \mathrm{H}-3,84-86$ & 164.05 & CUBE671291 & -3.6 & 1.3 & 12.92 & 1.72 & 4.85 & 0.19 & $6.962 \mathrm{E}-10$ & 0.56 & $3.32 \mathrm{E}-01$ \\
\hline $18 \mathrm{H}-4,84-86$ & 165.55 & CUBE671301 & 2.6 & 7.5 & 14.25 & 1.72 & 5.62 & 0.93 & 3.677E-09 & 0.69 & $1.36 \mathrm{E}+00$ \\
\hline $18 \mathrm{H}-5,84-86$ & 167.05 & CUBE671311 & 8.0 & 12.9 & 14.12 & 1.70 & 5.60 & 1.61 & $6.391 \mathrm{E}-09$ & 1.12 & $1.44 \mathrm{E}+00$ \\
\hline $18 \mathrm{H}-6,84-86$ & 168.55 & CUBE671321 & 13.4 & 18.3 & 14.23 & 1.64 & 5.88 & 2.18 & 8.997E-09 & 1.73 & $1.26 \mathrm{E}+00$ \\
\hline $18 \mathrm{H}-7,69-71$ & 169.80 & CUBE671331 & 2.8 & 7.7 & 14.21 & 1.70 & 5.64 & 0.95 & 3.779E-09 & 1.06 & $8.98 \mathrm{E}-01$ \\
\hline $19 \mathrm{H}-1,94-96$ & 170.65 & CUBE672211 & 4.6 & 9.5 & 14.62 & 1.69 & 5.95 & 1.12 & 4.537E-09 & 1.54 & 7.25E-01 \\
\hline $19 \mathrm{H}-2,84-86$ & 171.97 & CUBE672221 & -5.1 & -0.2 & 12.25 & 1.74 & 4.40 & -0.03 & $-9.029 E-11$ & 1.24 & $-2.02 \mathrm{E}-02$ \\
\hline $19 \mathrm{H}-3,84-86$ & 173.47 & CUBE672231 & 0.4 & 5.3 & 15.21 & 1.71 & 6.21 & 0.59 & $2.418 \mathrm{E}-09$ & 1.35 & $4.40 \mathrm{E}-01$ \\
\hline $19 \mathrm{H}-4,84-86$ & 174.97 & CUBE672241 & -2.6 & 2.3 & 13.12 & 1.60 & 5.33 & 0.30 & $1.223 \mathrm{E}-09$ & 1.01 & 2.97E-01 \\
\hline $19 \mathrm{H}-5,84-86$ & 176.47 & CUBE672251 & -2.2 & 2.7 & 14.51 & 1.68 & 5.90 & 0.32 & 1.290E-09 & 1.13 & $2.80 \mathrm{E}-01$ \\
\hline $19 \mathrm{H}-6,84-86$ & 177.97 & CUBE672261 & -1.5 & 3.4 & 13.81 & 1.65 & 5.57 & 0.43 & 1.717E-09 & 1.14 & $3.75 \mathrm{E}-01$ \\
\hline $20 \mathrm{H}-1,84-86$ & 180.05 & CUBE673001 & -0.1 & 4.8 & 14.72 & 1.70 & 5.95 & 0.56 & $2.272 \mathrm{E}-09$ & 0.77 & $7.34 \mathrm{E}-01$ \\
\hline $20 \mathrm{H}-2,84-86$ & 181.55 & CUBE673011 & 3.6 & 8.5 & 12.88 & 1.58 & 5.23 & 1.13 & 4.592E-09 & 1.43 & $7.93 \mathrm{E}-01$ \\
\hline $20 \mathrm{H}-3,84-86$ & 183.05 & CUBE673021 & 3.8 & 8.7 & 13.64 & 1.60 & 5.66 & 1.07 & $4.460 \mathrm{E}-09$ & 1.27 & $8.46 \mathrm{E}-01$ \\
\hline $20 \mathrm{H}-4,84-86$ & 184.55 & CUBE673031 & 0.2 & 5.1 & 14.55 & 1.48 & 6.72 & 0.53 & $2.455 \mathrm{E}-09$ & 2.25 & $2.36 \mathrm{E}-01$ \\
\hline $20 \mathrm{H}-5,84-86$ & 186.05 & CUBE673041 & -1.1 & 3.8 & 12.59 & 1.70 & 4.72 & 0.56 & $2.113 \mathrm{E}-09$ & 0.48 & $1.17 \mathrm{E}+00$ \\
\hline $20 \mathrm{H}-6,84-86$ & 187.55 & CUBE673051 & -1.1 & 3.8 & 14.45 & 1.68 & 5.87 & 0.46 & 1.853E-09 & 0.39 & $1.17 \mathrm{E}+00$ \\
\hline $20 \mathrm{H}-7,39-41$ & 188.40 & CUBE673061 & -2.0 & 2.9 & 15.06 & 1.73 & 6.05 & 0.34 & $1.364 \mathrm{E}-09$ & 0.86 & $3.96 \mathrm{E}-01$ \\
\hline
\end{tabular}


Table T21 (continued).

\begin{tabular}{|c|c|c|c|c|c|c|c|c|c|c|c|}
\hline \multirow[b]{2}{*}{$\begin{array}{l}\text { Core, section, } \\
\text { interval }(\mathrm{cm})\end{array}$} & \multirow[b]{2}{*}{$\begin{array}{l}\text { Depth } \\
\operatorname{CSF}(\mathrm{m})\end{array}$} & \multirow[b]{2}{*}{ LIMS ID } & & \multirow[b]{2}{*}{$\begin{array}{l}\text { Total } \\
\text { mass } \\
(\mathrm{g})\end{array}$} & \multirow[b]{2}{*}{$\begin{array}{l}\text { Bulk } \\
\text { density } \\
\left(\mathrm{g} / \mathrm{cm}^{3}\right)\end{array}$} & \multirow[b]{2}{*}{$\begin{array}{l}\text { Volume } \\
\left(\mathrm{cm}^{3}\right)\end{array}$} & \multicolumn{3}{|c|}{ Susceptibility } & \multirow[b]{2}{*}{$\begin{array}{l}\text { Scale } \\
\text { factor }\end{array}$} \\
\hline & & & $\begin{array}{c}\text { Susce } \\
\text { Raw } \\
\left(10^{-6}\right)\end{array}$ & 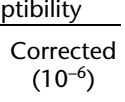 & & & & $\begin{array}{c}\text { Volume } \\
\text { normalized } \\
\left(10^{-5}\right)\end{array}$ & $\begin{array}{c}\text { Mass } \\
\text { normalized } \\
\left(\mathrm{m}^{3} / \mathrm{kg}\right)\end{array}$ & $\begin{array}{l}\text { Whole core } \\
\text { (raw values) }\end{array}$ & \\
\hline $21 \mathrm{H}-1,84-86$ & 189.55 & CUBE673801 & -2.6 & 2.3 & 14.52 & 1.79 & 5.54 & 0.28 & $1.085 \mathrm{E}-09$ & 1.70 & 1.67E-01 \\
\hline $21 \mathrm{H}-2,84-86$ & 191.05 & CUBE673811 & -2.7 & 2.2 & 14.60 & 1.71 & 5.84 & 0.27 & $1.064 \mathrm{E}-09$ & 1.58 & $1.69 \mathrm{E}-01$ \\
\hline $21 \mathrm{H}-3,84-86$ & 192.55 & CUBE673821 & -4.1 & 0.8 & 14.70 & 1.87 & 5.40 & 0.10 & $3.843 \mathrm{E}-10$ & 1.44 & $7.26 \mathrm{E}-02$ \\
\hline $21 \mathrm{H}-4,84-86$ & 194.05 & CUBE673831 & -1.1 & 3.8 & 13.15 & 1.72 & 4.99 & 0.53 & $2.016 \mathrm{E}-09$ & 1.55 & $3.43 \mathrm{E}-01$ \\
\hline $21 \mathrm{H}-5,84-86$ & 195.55 & CUBE673841 & 3.3 & 8.2 & 13.81 & 1.78 & 5.19 & 1.11 & 4.174E-09 & 2.26 & $4.91 \mathrm{E}-01$ \\
\hline $21 \mathrm{H}-6,84-86$ & 197.05 & CUBE673851 & -3.0 & 1.9 & 14.42 & 1.67 & 5.89 & 0.22 & $9.102 \mathrm{E}-10$ & 1.89 & $1.18 \mathrm{E}-01$ \\
\hline $21 \mathrm{H}-7,29-31$ & 198.00 & CUBE673861 & 2.3 & 7.2 & 13.82 & 1.70 & 5.43 & 0.93 & $3.656 \mathrm{E}-09$ & 2.11 & $4.41 \mathrm{E}-01$ \\
\hline $22 \mathrm{H}-2,84-86$ & 200.55 & CUBE674691 & -1.6 & 3.3 & 13.29 & 1.71 & 5.09 & 0.46 & $1.742 \mathrm{E}-09$ & 2.26 & $2.01 \mathrm{E}-01$ \\
\hline $22 \mathrm{H}-3,84-86$ & 202.05 & CUBE674701 & -2.3 & 2.6 & 11.70 & 1.62 & 4.39 & 0.42 & 1.559E-09 & 1.71 & $2.44 \mathrm{E}-01$ \\
\hline $22 \mathrm{H}-4,84-86$ & 203.55 & CUBE674711 & -5.8 & -0.9 & 13.90 & 1.77 & 5.27 & -0.12 & $-4.558 \mathrm{E}-10$ & 1.71 & $-7.01 \mathrm{E}-02$ \\
\hline $22 \mathrm{H}-5,84-86$ & 205.05 & CUBE674721 & 10.8 & 15.7 & 14.14 & 1.72 & 5.54 & 1.98 & 7.777E-09 & 3.98 & $4.98 \mathrm{E}-01$ \\
\hline $22 \mathrm{H}-6,84-86$ & 206.55 & CUBE674731 & 85.6 & 90.5 & 11.87 & 1.55 & 4.71 & 13.46 & 5.337E-08 & 15.14 & $8.89 \mathrm{E}-01$ \\
\hline $23 X-1,84-86$ & 207.75 & CUBE675301 & 47.0 & 51.9 & 13.63 & 1.55 & 5.85 & 6.21 & $2.665 \mathrm{E}-08$ & 8.92 & $6.96 \mathrm{E}-01$ \\
\hline $23 X-2,104-106$ & 209.45 & CUBE675311 & 61.9 & 66.8 & 13.82 & 1.53 & 6.03 & 7.76 & $3.384 \mathrm{E}-08$ & 11.76 & $6.59 \mathrm{E}-01$ \\
\hline $23 X-3,89-91$ & 210.80 & CUBE675321 & 67.0 & 71.9 & 13.61 & 1.69 & 5.34 & 9.42 & $3.699 \mathrm{E}-08$ & 12.09 & 7.79E-01 \\
\hline $23 X-4,109-111$ & 212.50 & CUBE675331 & 45.5 & 50.4 & 12.60 & 1.26 & 6.35 & 5.56 & $2.801 \mathrm{E}-08$ & 9.78 & $5.69 \mathrm{E}-01$ \\
\hline 23X-5, 89-91 & 213.80 & CUBE675341 & 54.6 & 59.5 & 13.50 & 1.63 & 5.48 & 7.60 & $3.085 \mathrm{E}-08$ & 9.32 & $8.16 \mathrm{E}-01$ \\
\hline $23 \mathrm{X}-6,89-91$ & 215.30 & CUBE675351 & 51.1 & 56.0 & 14.66 & 1.84 & 5.46 & 7.18 & $2.673 \mathrm{E}-08$ & 8.92 & $8.04 \mathrm{E}-01$ \\
\hline $24 X-1,87-89$ & 215.38 & CUBE675891 & 44.9 & 49.8 & 14.12 & 1.68 & 5.68 & 6.13 & $2.466 \mathrm{E}-08$ & 9.85 & $6.23 \mathrm{E}-01$ \\
\hline $24 X-2,76-78$ & 216.77 & CUBE675901 & 46.1 & 51.0 & 13.60 & 1.35 & 6.65 & 5.37 & $2.624 \mathrm{E}-08$ & 9.30 & $5.77 \mathrm{E}-01$ \\
\hline $24 X-3,82-84$ & 218.33 & CUBE675911 & 47.5 & 52.4 & 14.10 & 1.71 & 5.55 & 6.62 & $2.603 \mathrm{E}-08$ & 9.45 & $7.00 \mathrm{E}-01$ \\
\hline $24 \mathrm{X}-4,92-94$ & 219.93 & CUBE675921 & 47.0 & 51.9 & 13.78 & 1.60 & 5.74 & 6.33 & $2.638 \mathrm{E}-08$ & 8.77 & $7.22 \mathrm{E}-01$ \\
\hline $24 X-5,97-99$ & 221.48 & CUBE675931 & 42.1 & 47.0 & 14.49 & 1.44 & 6.89 & 4.77 & $2.268 \mathrm{E}-08$ & 9.72 & $4.91 \mathrm{E}-01$ \\
\hline $24 \mathrm{X}-6,84-86$ & 222.85 & CUBE675941 & 46.3 & 51.2 & 14.75 & 1.60 & 6.35 & 5.64 & $2.428 \mathrm{E}-08$ & 11.23 & $5.03 \mathrm{E}-01$ \\
\hline $24 X-7,29-31$ & 223.80 & CUBE675951 & 52.7 & 57.6 & 14.60 & 1.74 & 5.74 & 7.02 & $2.760 \mathrm{E}-08$ & 10.68 & $6.57 \mathrm{E}-01$ \\
\hline $25 X-1,94-96$ & 225.05 & CUBE677081 & 50.8 & 55.7 & 11.57 & 1.19 & 5.85 & 6.66 & $3.369 \mathrm{E}-08$ & 11.06 & $6.02 \mathrm{E}-01$ \\
\hline $25 X-2,100-102$ & 226.61 & CUBE677091 & 64.8 & 69.7 & 12.19 & 1.61 & 4.73 & 10.30 & $4.000 E-08$ & 12.14 & $8.49 \mathrm{E}-01$ \\
\hline $25 X-3,100-102$ & 228.11 & CUBE677101 & 62.8 & 67.7 & 12.29 & 1.36 & 5.67 & 8.36 & $3.854 \mathrm{E}-08$ & 10.59 & $7.90 \mathrm{E}-01$ \\
\hline $25 X-4,86-88$ & 229.47 & CUBE677111 & 54.9 & 59.8 & 12.40 & 1.87 & 4.18 & 10.00 & $3.374 \mathrm{E}-08$ & 10.51 & $9.52 \mathrm{E}-01$ \\
\hline $25 X-5,84-86$ & 230.95 & CUBE677121 & 17.2 & 22.1 & 8.68 & 1.45 & 2.82 & 5.48 & 1.779E-08 & 8.86 & $6.18 \mathrm{E}-01$ \\
\hline $25 X-6,69-71$ & 232.30 & CUBE677131 & 35.0 & 39.9 & 9.99 & 1.95 & 2.77 & 10.09 & 2.794E-08 & 10.23 & $9.86 \mathrm{E}-01$ \\
\hline $26 X-1,72-74$ & 234.33 & CUBE678031 & 46.9 & 51.8 & 12.23 & 1.62 & 4.72 & 7.68 & $2.966 \mathrm{E}-08$ & 11.21 & $6.86 \mathrm{E}-01$ \\
\hline $26 \mathrm{X}-2,134-136$ & 236.45 & CUBE678041 & 40.2 & 45.1 & 10.84 & 1.68 & 3.73 & 8.47 & $2.915 \mathrm{E}-08$ & 12.96 & $6.54 \mathrm{E}-01$ \\
\hline $26 X-3,112-114$ & 237.73 & CUBE678051 & 49.6 & 54.5 & 11.84 & 1.72 & 4.21 & 9.06 & $3.220 \mathrm{E}-08$ & 11.58 & $7.82 \mathrm{E}-01$ \\
\hline $26 \mathrm{X}-4,117-119$ & 239.28 & CUBE678061 & 41.8 & 46.7 & 11.72 & 1.55 & 4.61 & 7.09 & 2.787E-08 & 10.74 & $6.60 \mathrm{E}-01$ \\
\hline $26 X-5,90-92$ & 240.51 & CUBE678071 & 44.0 & 48.9 & 10.36 & 1.60 & 3.60 & 9.50 & $3.302 \mathrm{E}-08$ & 13.55 & $7.01 \mathrm{E}-01$ \\
\hline $26 \mathrm{X}-6,82-84$ & 241.93 & CUBE678021 & 82.5 & 87.4 & 12.51 & 1.75 & 4.52 & 13.54 & $4.892 \mathrm{E}-08$ & 18.98 & $7.13 \mathrm{E}-01$ \\
\hline $28 \mathrm{X}-1,129-131$ & 254.10 & CUBE679881 & 168.8 & 173.7 & 12.05 & 1.41 & 5.29 & 23.00 & $1.009 \mathrm{E}-07$ & 36.62 & $6.28 \mathrm{E}-01$ \\
\hline $28 X-3,77-79$ & 256.58 & CUBE679891 & 240.1 & 245.0 & 11.80 & 1.35 & 5.33 & 32.19 & $1.453 \mathrm{E}-07$ & 36.87 & $8.73 \mathrm{E}-01$ \\
\hline $28 X-4,68-70$ & 257.99 & CUBE679901 & 129.7 & 134.6 & 9.60 & 1.40 & 3.58 & 26.34 & $9.815 \mathrm{E}-08$ & 31.87 & $8.26 \mathrm{E}-01$ \\
\hline $28 X-5,75-77$ & 259.56 & CUBE679911 & 158.0 & 162.9 & 12.00 & 1.45 & 5.11 & 22.30 & $9.502 \mathrm{E}-08$ & 26.46 & $8.43 \mathrm{E}-01$ \\
\hline $28 X-6,65-67$ & 260.96 & CUBE679931 & 146.8 & 151.7 & 13.39 & 1.59 & 5.53 & 19.19 & 7.931E-08 & 24.79 & 7.74E-01 \\
\hline 29X-1, 94-96 & 263.35 & CUBE680611 & 247.2 & 252.1 & 13.85 & 1.50 & 6.17 & 28.59 & $1.274 \mathrm{E}-07$ & 31.62 & $9.04 \mathrm{E}-01$ \\
\hline $29 X-3,105-107$ & 264.97 & CUBE680621 & 163.1 & 168.0 & 11.86 & 1.50 & 4.85 & 24.27 & $9.916 \mathrm{E}-08$ & 26.43 & $9.18 \mathrm{E}-01$ \\
\hline 29X-4, 109-111 & 266.51 & CUBE680631 & 122.6 & 127.5 & 12.36 & 1.50 & 5.18 & 17.23 & $7.221 \mathrm{E}-08$ & 26.00 & $6.63 \mathrm{E}-01$ \\
\hline $29 X-5,103-105$ & 267.95 & CUBE680641 & 121.3 & 126.2 & 9.39 & 1.46 & 3.28 & 26.92 & $9.408 \mathrm{E}-08$ & 33.45 & $8.05 \mathrm{E}-01$ \\
\hline $29 X-6,71-73$ & 269.13 & CUBE680651 & 200.6 & 205.5 & 12.48 & 1.10 & 7.18 & 20.04 & $1.153 \mathrm{E}-07$ & 32.64 & $6.14 \mathrm{E}-01$ \\
\hline $29 X-7,123-125$ & 270.81 & CUBE680661 & 210.4 & 215.3 & 12.19 & 1.60 & 4.76 & 31.65 & $1.236 \mathrm{E}-07$ & 26.85 & $1.18 \mathrm{E}+00$ \\
\hline $30 X-1,113-115$ & 273.24 & CUBE681581 & 107.2 & 112.1 & 12.59 & 1.08 & 7.41 & 10.59 & $6.233 \mathrm{E}-08$ & 16.24 & $6.52 \mathrm{E}-01$ \\
\hline $30 X-2,106-108$ & 274.67 & CUBE681591 & 92.2 & 97.1 & 9.41 & 1.70 & 2.83 & 24.01 & 7.219E-08 & 22.44 & $1.07 \mathrm{E}+00$ \\
\hline $30 X-3,94-96$ & 276.05 & CUBE681601 & 156.0 & 160.9 & 13.63 & 1.68 & 5.37 & 20.98 & $8.263 \mathrm{E}-08$ & 23.97 & $8.76 \mathrm{E}-01$ \\
\hline 30X-4, 92-94 & 277.53 & CUBE681611 & 207.7 & 212.6 & 13.89 & 1.67 & 5.56 & 26.77 & $1.071 \mathrm{E}-07$ & 30.95 & $8.65 \mathrm{E}-01$ \\
\hline $30 X-5,89-91$ & 279.00 & CUBE681621 & 257.5 & 262.4 & 13.85 & 1.60 & 5.79 & 31.74 & $1.326 \mathrm{E}-07$ & 33.56 & $9.46 \mathrm{E}-01$ \\
\hline $30 X-6,89-91$ & 280.50 & CUBE681631 & 195.3 & 200.2 & 12.70 & 1.79 & 4.54 & 30.86 & $1.103 \mathrm{E}-07$ & 24.73 & $1.25 \mathrm{E}+00$ \\
\hline \multirow[t]{2}{*}{$30 x-7,54-56$} & 281.15 & CUBE681641 & 241.9 & 246.8 & 12.26 & 1.37 & 5.58 & 30.94 & $1.409 \mathrm{E}-07$ & 40.20 & 7.70E-01 \\
\hline & & & & & & & & & \multicolumn{2}{|c|}{ Mean scale factor: } & 7.06E-01 \\
\hline
\end{tabular}

Notes: Depth = depth to middle of discrete sample measured in meters using the core depth below seafloor, method A (CSF), depth scale. LIMS ID = sample identification within the Laboratory Information Management System (LIMS) database. Susceptibility raw = volume magnetic susceptibility (in SI units) of the discrete sample measured in the Kappabridge with the volume of the cube assumed to be $7 \mathrm{~cm}^{3}$. Susceptibility corrected $=$ the susceptibility of the plastic cube with a label was determined to be $-4.9 \times 10^{-6}(\mathrm{SI})$ with a standard error of $\pm 0.19 \times 10^{-6}$. Mass $=$ mass of sample including mass of plastic cube, which has a mean of $4.5921 \mathrm{~g}$. Bulk density = density from moisture and density (MAD) measurements. When these were not available or were obviously anomalous, we used a density of $1.2 \mathrm{~m}^{3} / \mathrm{kg}$. Volume $=$ volume of sediments, calculated by subtracting mass of plastic cube from total mass and then dividing by bulk density. Volume normalized susceptibility = susceptibility of discrete samples normalized by true sample volume. These are unitless in the SI unit system. Mass normalized susceptibility = susceptibility of discrete samples normalized by mass of sediments in each sample cube. Scale factor = factor whole-core raw susceptibility values would need to be multiplied by to convert them to SI volume normalized susceptibilities. 
Table T22. Magnetostratigraphy, Site U1334. This table is available in an oversized format.

Table T23. Interstitial water data from squeezed whole-round samples, Site U1334. (See table notes.)

\begin{tabular}{|c|c|c|c|c|c|c|c|c|c|c|c|c|c|c|c|c|c|}
\hline \multirow{2}{*}{$\begin{array}{l}\text { Core, section, } \\
\text { interval }(\mathrm{cm})\end{array}$} & \multicolumn{2}{|c|}{ Depth $(m)$} & \multirow[b]{2}{*}{$\mathrm{pH}$} & \multirow{2}{*}{$\begin{array}{c}\text { Alkalinity } \\
(\mathrm{mM})\end{array}$} & \multirow{2}{*}{$\begin{array}{c}\mathrm{Cl}^{-} \\
(\mathrm{mM})\end{array}$} & \multirow{2}{*}{$\begin{array}{l}\mathrm{SO}_{4}{ }^{2-} \\
(\mathrm{mM})\end{array}$} & \multirow{2}{*}{$\begin{array}{c}\mathrm{HPO}_{4}{ }^{2-} \\
(\mu \mathrm{M})\end{array}$} & \multirow{2}{*}{$\begin{array}{c}\mathrm{H}_{4} \mathrm{SiO}_{4} \\
(\mu \mathrm{M})\end{array}$} & \multirow{2}{*}{$\begin{array}{l}\mathrm{Mn}^{2+} \\
(\mu \mathrm{M})\end{array}$} & \multirow{2}{*}{$\begin{array}{l}\mathrm{Fe}^{2+} \\
(\mu \mathrm{M})\end{array}$} & \multirow{2}{*}{$\begin{array}{l}\mathrm{Ca}^{2+} \\
(\mathrm{mM})\end{array}$} & \multirow{2}{*}{$\begin{array}{l}\mathrm{Mg}^{2+} \\
(\mathrm{mM})\end{array}$} & \multirow{2}{*}{$\begin{array}{c}\text { B } \\
(\mu \mathrm{M})\end{array}$} & \multirow{2}{*}{$\begin{array}{c}\mathrm{Sr}^{2+} \\
(\mu \mathrm{M})\end{array}$} & \multirow{2}{*}{$\begin{array}{l}\mathrm{Ba}^{2+} \\
(\mu \mathrm{M})\end{array}$} & \multirow{2}{*}{$\begin{array}{c}\mathrm{Li}^{+} \\
(\mu \mathrm{M})\end{array}$} & \multirow{2}{*}{$\begin{array}{c}\mathrm{K}^{+} \\
(\mathrm{mM})\end{array}$} \\
\hline & CSF & CCSF-A & & & & & & & & & & & & & & & \\
\hline \multicolumn{18}{|l|}{ 320-U1334A- } \\
\hline $1 \mathrm{H}-2,145-150$ & 2.95 & 2.95 & 7.58 & 2.73 & 553 & 28.4 & 1.86 & 417 & 0.56 & 0.74 & 10.3 & 52.4 & 485 & 78.0 & 0.83 & 25.3 & 10.6 \\
\hline $1 \mathrm{H}-4,145-150$ & 5.95 & 5.95 & 7.62 & 2.83 & 555 & 28.6 & 1.28 & 456 & 0.44 & 0.36 & 10.6 & 53.5 & 499 & 82.6 & 0.86 & 25.0 & 11.2 \\
\hline $2 \mathrm{H}-2,145-150$ & 11.15 & 12.02 & 7.66 & 3.00 & 557 & 28.2 & 0.96 & 494 & 0.93 & $\mathrm{BDL}$ & 10.7 & 52.3 & 496 & 80.8 & 0.97 & 25.9 & 11.0 \\
\hline $2 \mathrm{H}-5,145-150$ & 15.65 & 16.52 & 7.65 & 3.32 & 558 & 28.4 & 0.84 & 511 & $\mathrm{BDL}$ & $\mathrm{BDL}$ & 10.8 & 52.5 & 499 & 86.7 & 0.89 & 22.6 & 11.2 \\
\hline $3 \mathrm{H}-2,145-150$ & 20.65 & 22.62 & 7.62 & 3.04 & 560 & 28.2 & 0.86 & 492 & 1.63 & $\mathrm{BDL}$ & 10.7 & 52.7 & 491 & 82.6 & 1.50 & 21.7 & 11.1 \\
\hline $3 \mathrm{H}-5,145-150$ & 25.15 & 27.12 & 7.62 & 3.00 & 560 & 26.3 & 0.71 & 495 & 0.39 & $\mathrm{BDL}$ & 10.7 & 53.0 & 495 & 84.5 & 0.99 & 21.2 & 11.0 \\
\hline $4 \mathrm{H}-2,145-150$ & 30.15 & 33.63 & 7.61 & & 563 & 28.5 & 0.68 & 489 & 1.46 & 2.11 & 11.0 & 54.0 & 488 & 87.6 & 1.09 & 20.7 & 11.4 \\
\hline $4 \mathrm{H}-5$, & 3 & & 7.60 & & 56 & 7.5 & 0.8 & 528 & 0.47 & & 1.0 & 53.9 & 482 & 8.8 & .00 & 20.5 & 11.4 \\
\hline $5 \mathrm{H}-2,1$ & 9.65 & 4.42 & 7.52 & 3. & 560 & 27.6 & 0.77 & 519 & 0.69 & BDL & 1.0 & 53.1 & 494 & 89.7 & 1.24 & 0.4 & 11.5 \\
\hline $5 \mathrm{H}-5,1$ & 44.1 & & 7.52 & & 565 & 26.5 & 0.77 & 521 & 1.06 & 0.29 & 10.8 & 53.1 & 493 & 89.7 & .92 & .9 & 11.2 \\
\hline $6 \mathrm{H}-2,145-150$ & 49.15 & 56.08 & 7.58 & 3.22 & 563 & 25.4 & 0.77 & 501 & 1.01 & $\mathrm{BDL}$ & 10.9 & 53.2 & 482 & 89.7 & 1.01 & 19.3 & 11.0 \\
\hline $6 \mathrm{H}-5,145-150$ & 53.65 & & 7.54 & & & 25.1 & & & & & & & 477 & & & & 11.4 \\
\hline & 6 & & 7.4 & & 56 & & & & & 1. & & 55 & & 88.9 & & .0 & 10.8 \\
\hline $8 \mathrm{H}-3$ & 9.60 & 78.6 & 7.48 & 3.26 & 56 & & 0.92 & 554 & 3.23 & & 8 & 52 & 45 & 90.3 & 95 & .1 & 10.5 \\
\hline $9 \mathrm{H}-3,140-150$ & 79.10 & 90.32 & - & - & 562 & 26.2 & 0.81 & 592 & 4.31 & 1.04 & 10.9 & 52.5 & 466 & 95.2 & 1.04 & 18.2 & 10.9 \\
\hline $10 \mathrm{H}-3,140-150$ & 88.60 & 99.91 & 7.45 & 3.17 & 558 & 26.8 & 0.92 & 583 & 5.15 & $\mathrm{BDL}$ & 11.4 & 52.2 & 469 & 102.2 & 0.96 & 17.5 & 11.2 \\
\hline & 98.10 & & & & & & & 57 & & 0. & & 52 & 451 & & & 17.1 & 11.2 \\
\hline $12 \mathrm{H}$ & 107.60 & 12 & 7.51 & & 56 & 25.5 & 0.7 & 589 & 5.97 & & 11.4 & 53.9 & 476 & 105.1 & 0.95 & 16.8 & 11.5 \\
\hline 131 & 117.60 & & 7.63 & & 56 & 26.6 & 0.8 & 620 & 4.77 & 0.3 & 1 & 53 & 448 & 104.2 & 1.02 & 16.0 & 11.3 \\
\hline $14 \mathrm{H}-3,140-150$ & 126.60 & 143. & 7.51 & 3.41 & 561 & 26.1 & 0.75 & 623 & 3.76 & $\mathrm{BDL}$ & 11.5 & 53.2 & 452 & 103.0 & 0.92 & 15.8 & 11.3 \\
\hline $15 \mathrm{H}-3,140-150$ & 134.70 & 153.56 & 7.41 & 3.61 & 564 & 25.7 & 0.79 & 668 & 2.79 & 0.49 & 11.4 & 52.0 & 435 & 103.5 & 0.94 & 15.6 & 11.0 \\
\hline $16 \mathrm{r}$ & & & 7.57 & & 56 & 24 & 0.62 & 70 & & 4. & & 52 & 463 & & & 17 & 11.2 \\
\hline 17 ㄱ & 155.10 & & 7.89 & & 55 & 24.4 & 0.5 & 73 & 1.52 & 4.8 & 11.0 & 52.2 & 442 & 107.0 & 1.08 & 17.4 & 11.3 \\
\hline $18 \mathrm{H}-3,140-150$ & 164.60 & 188.70 & 7.81 & & 56 & 25.5 & 0.61 & 667 & 1.1 & 2.52 & 11.2 & 53.4 & 461 & 105.5 & 0.96 & 16.6 & 11.3 \\
\hline $19 \mathrm{H}-3,140-150$ & 174.02 & 200.44 & 7.42 & 3.29 & 563 & 25.2 & 0.63 & 714 & 1.00 & 3.03 & 11.1 & 52.6 & 456 & 105.9 & 0.99 & 15.7 & 11.2 \\
\hline $20 \mathrm{H}-3,140-150$ & 183.60 & 210.58 & 7.47 & 4.02 & 559 & 24.5 & 0.64 & 795 & 1.03 & 2.30 & 10.7 & 51.8 & 466 & 103.9 & 0.93 & 16.7 & 10.8 \\
\hline & & & 7.42 & & 55 & & & 664 & 0.67 & & & 52 & 448 & 99.6 & & & 10.4 \\
\hline & & & 7.5 & & & & 0.7 & 77 & & 0.3 & 1 & 52 & 45 & 99.0 & 0.98 & 15 & 10.5 \\
\hline $23 X-3,140-150$ & 211.30 & 255.60 & 7.60 & & 562 & 25.9 & 0.77 & 826 & 0.38 & 0.41 & 11.3 & 52.6 & 442 & 101.5 & 1.05 & 15.8 & 10.6 \\
\hline $24 \mathrm{X}-2,140-150$ & 217.40 & 264.30 & 7.53 & 3.34 & 562 & 25.9 & 0.73 & 745 & 1.01 & 1.12 & 11.4 & 52.4 & 448 & 98.7 & 1.07 & 15.7 & 10.7 \\
\hline $25 X-3,140-150$ & 228.50 & 275.90 & 7.51 & 3.24 & 564 & 25.5 & 0.62 & 764 & 0.30 & 0.28 & 11.0 & 51.2 & 422 & 99.3 & 0.98 & 16.9 & 10.4 \\
\hline $26 X-3,14$ & 238.00 & 285.71 & 7.5 & 3.3 & 55 & 24.7 & 0.6 & 746 & $\mathrm{BD}$ & 0.2 & 10. & 51.2 & 44 & 97.4 & 1.13 & 19.0 & 10.7 \\
\hline & & & & & & & & 830 & & & & 52.2 & & 94.3 & 1.01 & 26.4 & 10.3 \\
\hline $30 \times-3,140-150$ & 275.37 & 326.34 & 7.57 & 3.07 & 553 & 27.2 & 0.51 & 842 & 1.16 & $\mathrm{BDL}$ & 10.8 & 52.9 & 403 & 85.6 & 1.02 & 29.9 & 10.1 \\
\hline
\end{tabular}

Notes: $-=$ no data. $\mathrm{BDL}=$ below detection limit $\left(\mathrm{Mn}^{2+}=0.3 \mu \mathrm{M}, \mathrm{Fe}^{2+}=0.2 \mu \mathrm{M}\right) . \mathrm{H}_{4} \mathrm{SiO}_{4}$ values measured by different techniques during Expeditions 320 and 321 disagree significantly, especially for low values. Therefore, caution should be used concerning the $\mathrm{H}_{4} \mathrm{SiO}_{4}$ data and comparison between the different expeditions. 
Table T24. Interstitial water data from rhizon samples, Site U1334. (See table notes.)

\begin{tabular}{|c|c|c|c|c|c|c|c|c|c|c|c|c|}
\hline \multirow{2}{*}{$\begin{array}{l}\text { Core, section, } \\
\text { interval }(\mathrm{cm})\end{array}$} & \multicolumn{2}{|c|}{ Depth $(m)$} & \multirow[b]{2}{*}{$\mathrm{pH}$} & \multirow{2}{*}{$\begin{array}{c}\text { Alkalinity } \\
(\mathrm{mM})\end{array}$} & \multirow{2}{*}{$\begin{array}{l}\mathrm{SO}_{4}{ }^{2-} \\
(\mathrm{mM})\end{array}$} & \multirow{2}{*}{$\begin{array}{c}\mathrm{H}_{4} \mathrm{SiO}_{4} \\
(\mu \mathrm{M})\end{array}$} & \multirow{2}{*}{$\begin{array}{l}\mathrm{Mn}^{2+} \\
(\mu \mathrm{M})\end{array}$} & \multirow{2}{*}{$\begin{array}{l}\mathrm{Fe}^{2+} \\
(\mu \mathrm{M})\end{array}$} & \multirow{2}{*}{$\begin{array}{c}B \\
(\mu M)\end{array}$} & \multirow{2}{*}{$\begin{array}{c}\mathrm{Sr}^{2+} \\
(\mu \mathrm{M})\end{array}$} & $\mathrm{Ba}^{2+}$ & \\
\hline & CSF & CCSF-A & & & & & & & & & $(\mu \mathrm{M})$ & M) \\
\hline 320-U1334B- & & & & & & & & & & & & \\
\hline & 122.45 & 141.44 & 7.5 & 3.23 & 23.5 & 700 & 5.44 & 0.60 & 492 & 97.5 & $\mathrm{BDL}$ & 16.7 \\
\hline $13 \mathrm{H}-6,75$ & 123.95 & 142.94 & 7.4 & 3.23 & 25.7 & 653 & 4.74 & 0.27 & 477 & 94.4 & BDL & 15.9 \\
\hline 320-U1334C- & & & & & & & & & & & & \\
\hline $13 \mathrm{H}-5,75$ & 20.75 & 145.88 & 7.5 & 3.17 & 26.7 & 728 & 4.31 & $\mathrm{BDL}$ & 477 & 101.5 & BDL & 16.9 \\
\hline $13 \mathrm{H}-6,75$ & 122.25 & 147.38 & 7.6 & 3.31 & 24.6 & 703 & 4.01 & BDL & 468 & 99.2 & BDL & 16.0 \\
\hline $14 \mathrm{H}-1,79$ & 124.29 & 151.35 & 7.6 & 3.09 & 24.6 & 572 & 3.48 & 0.20 & 491 & 99.2 & 0.85 & 15.6 \\
\hline $14 \mathrm{H}-2,79$ & 125.79 & 152.85 & 7.4 & 3.42 & 26.0 & 580 & 3.69 & 0.70 & 482 & 98.1 & 0.66 & 15.3 \\
\hline $14 \mathrm{H}-3,79$ & 127.29 & 154 & 7.4 & 3.18 & 24.5 & 667 & 3.05 & & 486 & 104.3 & BDL & 16.3 \\
\hline $14 \mathrm{H}-4,79$ & 128.79 & 155. & - & - & 24.6 & 623 & 3.04 & 23 & 485 & 100.5 & BDL & 16.2 \\
\hline $14 \mathrm{H}-5,79$ & 130.29 & 157.35 & 7.6 & 3.21 & 25.4 & 643 & 3.32 & 26 & 470 & 97.9 & $\mathrm{BDL}$ & 15.9 \\
\hline $14 \mathrm{H}-6,79$ & 131.79 & 158.85 & 7.5 & & 26.5 & 669 & 2.70 & 0.27 & 478 & & & 16.7 \\
\hline $15 \mathrm{H}-1,75$ & 133.75 & & 7.5 & & & & & & & 89.1 & & 19.4 \\
\hline $15 \mathrm{H}$ & 5.2 & & 7.5 & & 25.3 & 640 & 2.36 & & & 7.2 & & 5.3 \\
\hline $15 \mathrm{H}-3,75$ & 36.75 & & 7. & & 24.4 & 617 & 2.26 & & 46 & 4.9 & 52 & 5.1 \\
\hline $15 \mathrm{H}-4,75$ & 38.25 & 166 & 7.5 & 3.28 & 25.2 & 668 & 2.05 & DL & 48 & 98.8 & 3DL & 16.0 \\
\hline $15 \mathrm{H}-5,75$ & 139.75 & 167. & 7.6 & & 25.5 & 673 & 1.93 & 0.53 & 47 & 96.7 & BDL & 15.6 \\
\hline $15 \mathrm{H}-6,75$ & 141.25 & & 7.5 & & & & & & & 98.7 & & 5.6 \\
\hline $16 \mathrm{H}$ & 3.50 & & 7. & & 26.0 & 65 & 1.57 & & 47 & 97. & & 5.2 \\
\hline $16 \mathrm{H}-2,75$ & 144.75 & & 7.6 & & 24.6 & 684 & 1.56 & 69 & 485 & 100.1 & $3 \mathrm{DL}$ & 15.6 \\
\hline $16 \mathrm{H}-3,75$ & 146.25 & 175. & 7.6 & 3.35 & 26.1 & 690 & 1.52 & 1.42 & 479 & 101.1 & BDL & 5.5 \\
\hline $16 \mathrm{H}-4,75$ & 147.85 & & 7.7 & & 24.9 & 683 & 2.05 & 1.47 & 483 & 103.0 & 0.60 & 16.5 \\
\hline & 9.2 & & 7. & & & & & & & & & 5.2 \\
\hline $16 \mathrm{r}$ & 0.7 & & 7. & & 25.7 & 693 & 1.39 & 1 & 468 & & & 5.5 \\
\hline $17 \mathrm{H}-1$ & 1 & & 7. & & 26.2 & & 1.21 & & 48 & 100.1 & & 5.5 \\
\hline $17 \mathrm{H}-2,75$ & 154.25 & 184. & 7.6 & 3.3 & 24.4 & 731 & 1.26 & 0.57 & & & & 5.2 \\
\hline $17 \mathrm{H}-3$ & 5.75 & & 7.7 & & & & & & & & & 6.4 \\
\hline & & & & & & & & & & & & \\
\hline $17 \mathrm{H}-5$ & 88.75 & & 7. & & 23.7 & 720 & 1.08 & 2.27 & 466 & 7 & $\mathrm{BDL}$ & 15.1 \\
\hline & 50.25 & & 7. & & 25.6 & & & & 491 & 102 & & 16.3 \\
\hline $18 \mathrm{H}-1,75$ & 162.25 & 193.69 & 7.7 & 3.20 & 24.1 & 707 & 1.00 & 1.93 & 467 & 0 & & 16.0 \\
\hline & & & - & & & & & & & & & .8 \\
\hline 18 & 165.2 & & 7.9 & & 24. & 662 & 0.9 & & 476 & & & 5.3 \\
\hline & & & 7. & & 26 & & 0.5 & & 481 & & & 5.6 \\
\hline & & & 7.6 & & & & & & & 100.4 & & 15.6 \\
\hline $18 \mathrm{H}-6,75$ & 69.75 & & 7.5 & & 24.7 & & 0.91 & 2.81 & & & & 15.3 \\
\hline & & & 7 & & 26 & & 1. & & $4 \varepsilon$ & & & .6 \\
\hline 19 & & & 7. & & 25.8 & 665 & 0.7 & 52 & 474 & & $\mathrm{BDL}$ & 15.3 \\
\hline $19 \mathrm{H}-3,75$ & 1 & & 7.6 & & 25.2 & 69 & 0.77 & 54 & 473 & 8.9 & BDL & 15.5 \\
\hline $19 \mathrm{H}-4,75$ & 176.25 & 208. & 7.6 & & 25.6 & 663 & 0.84 & 1.82 & 469 & 96.1 & BDL & 15.0 \\
\hline & & & 7.5 & & 25.1 & & & 2.66 & & & & 15.4 \\
\hline & & & & & & & & & & & & \\
\hline $20 \mathrm{H}-$ & 1 & & 7 & & 25 & 6 & 1.0 & $2.4 \varepsilon$ & 46 & 99 & BDL & 15.7 \\
\hline $20 \mathrm{H}-2$ & 2.75 & & 7.4 & & 25.7 & & 0.87 & 1.43 & 474 & 97.6 & $\mathrm{BDL}$ & 15.6 \\
\hline $20 \mathrm{H}-3,75$ & 184.25 & & 7.5 & & 25.7 & 691 & 1.42 & 2.47 & 471 & 97.4 & $\mathrm{BDL}$ & 15.7 \\
\hline & & & 7.4 & & 24.5 & & 0.77 & & 471 & 99.4 & & 15.8 \\
\hline & & & 7.6 & & & & & & 480 & 100.4 & & 16.8 \\
\hline $20 \mathrm{H}-6$ & 8.75 & & 7. & & 24 & 733 & 0.7 & .87 & 461 & 97 & $\mathrm{BL}$ & 16.1 \\
\hline $21 \mathrm{H}-1,75$ & 190.75 & & 7.6 & & 25.5 & 712 & & 0.24 & 466 & 03.7 & $\mathrm{BD}$ & 17.5 \\
\hline $21 \mathrm{H}-2,75$ & 192.25 & & 7.6 & & 23.9 & 697 & 0.59 & 0.23 & 457 & 01.8 & BDL & 17.3 \\
\hline & & & 7.6 & & 24.8 & 692 & 0.5 & & 460 & 101.3 & & 17.0 \\
\hline & & & 7.6 & & 25. & & & & 48 & 99 & & \\
\hline & 15 & & 7.6 & & 25 & 69 & 0.5 & & 45 & 99 & BDL & 17.8 \\
\hline $21 \mathrm{H}-6,75$ & 198.25 & 232.45 & - & 3.02 & 24.6 & 708 & 0.56 & $\mathrm{DL}$ & 474 & 100.2 & $\mathrm{BDL}$ & 16.9 \\
\hline $22 \mathrm{H}-1,75$ & 200.25 & 236.05 & 7.6 & 3.25 & 24.7 & 649 & 0.45 & BDL & 465 & 00.4 & $\mathrm{BDL}$ & 17.8 \\
\hline $22 \mathrm{H}-2,75$ & 201.75 & & - & - & 24.1 & 459 & 0.46 & 0.23 & 465 & 101.5 & & 17.5 \\
\hline & & & 7.7 & & 25. & 65 & & & & & & 17.4 \\
\hline & & & 7.7 & & & & & & & 99 & & 16.9 \\
\hline $22 \mathrm{H}-5,75$ & 206.25 & 242.05 & 7.7 & 3.69 & 23.5 & 686 & 0.49 & 0.24 & 461 & 95.9 & $\mathrm{BDL}$ & 16.6 \\
\hline $22 \mathrm{H}-6,75$ & 207.75 & 243.55 & 7.6 & 3.58 & 24.9 & 668 & 0.27 & BDL & 471 & 95.7 & BDL & 16.9 \\
\hline $23 X-1,75$ & 209.75 & 250.6 & 7.7 & 2.31 & 25.3 & 371 & 1.74 & $\mathrm{BD}$ & 428 & 86.8 & BDL & 22.0 \\
\hline & & & 7.6 & & 26.8 & 45 & 1.03 & & 441 & 91.9 & BDL & 21.1 \\
\hline $23 X-3,75$ & 212.75 & 253.68 & 7.6 & 3.00 & 25.7 & 595 & 0.17 & 0.19 & 465 & 96.3 & $\mathrm{BDL}$ & 18.6 \\
\hline
\end{tabular}

Notes: $-=$ no data. $\mathrm{BDL}=$ below detection limit $\left(\mathrm{Mn}^{2+}=0.03 \mu \mathrm{M}, \mathrm{Fe}^{2+}=0.1 \mu \mathrm{M}, \mathrm{Ba}^{2+}=0.4 \mu \mathrm{M}\right)$ calculated as three times the standard deviation of multiple measures of a blank. $\mathrm{H}_{4} \mathrm{SiO}_{4}$ values measured by different techniques during Expeditions 320 and 321 disagree significantly, especially for low values. Therefore, caution should be used concerning the $\mathrm{H}_{4} \mathrm{SiO}_{4}$ data and comparison between the different expeditions. 
Table T25. Inorganic geochemistry of solid samples, Hole U1334A. (See table notes.)

\begin{tabular}{|c|c|c|c|c|c|c|c|c|c|c|c|c|c|c|c|c|c|c|c|}
\hline \multirow{2}{*}{$\begin{array}{l}\text { Core, section, } \\
\text { interval }(\mathrm{cm})\end{array}$} & \multirow{2}{*}{$\begin{array}{l}\text { Depth } \\
\text { CSF (m) }\end{array}$} & \multicolumn{10}{|c|}{ Major element oxide (wt\%) } & \multicolumn{8}{|c|}{ Trace element (ppm) } \\
\hline & & $\mathrm{SiO}_{2}$ & $\mathrm{Al}_{2} \mathrm{O}_{3}$ & $\mathrm{Fe}_{2} \mathrm{O}_{3} \mathrm{~T}$ & $\mathrm{MnO}$ & $\mathrm{MgO}$ & $\mathrm{CaO}$ & $\mathrm{Na}_{2} \mathrm{O}$ & $\mathrm{K}_{2} \mathrm{O}$ & $\mathrm{TiO}_{2}$ & $\mathrm{P}_{2} \mathrm{O}_{5}$ & $\mathrm{Ba}$ & $\mathrm{Cr}$ & $\mathrm{Cu}$ & $\mathrm{Sc}$ & $\mathrm{Sr}$ & $\mathrm{v}$ & $\mathrm{Y}$ & $\mathrm{Zr}$ \\
\hline \multicolumn{20}{|l|}{ 320-U1334A- } \\
\hline $1 \mathrm{H}-3,65-66$ & 3.65 & 52.11 & 12.10 & 6.87 & 2.81 & 3.78 & 1.27 & 4.47 & 2.21 & 0.57 & 0.79 & 9832 & 46.0 & 1606 & 39.2 & 376.9 & 115.4 & 269.9 & 234.5 \\
\hline $2 \mathrm{H}-3,64-65$ & 11.84 & 53.66 & 9.68 & 8.17 & 3.90 & 3.72 & 1.58 & 5.20 & 1.83 & 0.45 & 0.96 & 7706 & 31.6 & 1937 & 38.0 & 344.6 & 89.3 & 359.8 & 239.8 \\
\hline $3 \mathrm{H}-3,65-66$ & 21.35 & 23.35 & 3.07 & 3.05 & 0.73 & 1.52 & 30.93 & 3.05 & 0.74 & 0.14 & 0.43 & 2921 & 14.5 & 427 & 9.4 & 1326 & 22.4 & 83.7 & 81.9 \\
\hline $5 \mathrm{H}-3,65-66$ & 40.35 & 41.71 & 4.77 & 5.99 & 1.26 & 2.40 & 16.97 & 4.18 & 1.10 & 0.20 & 0.42 & 8156 & 24.4 & 748 & 11.3 & 1045 & 61.7 & 79.5 & 103.3 \\
\hline $6 \mathrm{H}-3,65-66$ & 49.85 & 7.42 & 0.21 & 0.56 & 0.12 & 0.43 & 39.65 & 1.24 & 0.12 & 0.01 & 0.22 & 1418 & $\mathrm{BDL}$ & 89 & 0.6 & 1824 & BDL & 17.6 & 18.1 \\
\hline $11 \mathrm{H}-3,65-66$ & 97.35 & 12.21 & 0.68 & 1.20 & 0.13 & 0.62 & 38.21 & 1.58 & 0.25 & 0.03 & 0.16 & 2221 & 6.3 & 160 & 2.1 & 2144 & $\mathrm{BDL}$ & 21.9 & 27.8 \\
\hline $14 \mathrm{H}-3,65-66$ & 125.85 & 11.43 & 0.54 & 1.01 & 0.17 & 0.52 & 42.34 & 1.45 & 0.21 & 0.02 & 0.29 & 1973 & 5.9 & 109 & 1.4 & 2212 & BDL & 18.1 & 22.0 \\
\hline $17 \mathrm{H}-3,65-66$ & 154.35 & 7.45 & 0.24 & 0.54 & 0.11 & 0.38 & 41.20 & 1.09 & 0.14 & 0.01 & 0.16 & 1494 & 19.4 & 46 & 0.5 & 2051 & $\mathrm{BDL}$ & 15.1 & 18.1 \\
\hline $20 \mathrm{H}-3,65-66$ & 182.85 & 8.42 & 0.29 & 0.68 & 0.07 & 0.42 & 39.07 & 1.16 & 0.18 & 0.01 & $\mathrm{BDL}$ & 1535 & $\mathrm{BDL}$ & 82 & 0.9 & 2010 & $\mathrm{BDL}$ & 13.9 & 22.0 \\
\hline $24 X-2,45-46$ & 216.45 & 13.35 & 0.28 & 0.96 & 0.20 & 0.46 & 40.70 & 1.20 & 0.15 & 0.01 & 0.21 & 1668 & BDL & 100 & 1.4 & 1681 & $\mathrm{BDL}$ & 12.8 & 23.8 \\
\hline $25 X-6,52-53$ & 232.12 & 22.56 & 0.30 & 1.17 & 0.31 & 0.58 & 36.01 & 1.62 & 0.18 & 0.01 & 0.26 & 1652 & BDL & 111 & 1.0 & 1357 & BDL & 17.3 & 20.1 \\
\hline $27 X-1,119-120$ & 244.39 & 8.79 & 0.21 & 0.99 & 0.19 & 0.45 & 40.55 & 1.01 & 0.10 & 0.01 & 0.20 & 1403 & 5.3 & 87 & 1.2 & 1805 & BDL & 15.6 & 22.4 \\
\hline $27 X-3,90-91$ & 247.10 & 23.63 & 1.76 & 3.62 & 1.21 & 1.20 & 34.18 & 1.61 & 0.61 & 0.06 & 0.28 & 3332 & 9.3 & 269 & 3.7 & 1776 & 28.7 & 38.9 & 44.0 \\
\hline $27 X-6,9-10$ & 249.79 & 33.14 & 1.26 & 4.55 & 1.42 & 1.56 & 29.75 & 2.02 & 0.47 & 0.06 & 0.31 & 3916 & 10.1 & 290 & 4.6 & 1334 & 39.0 & 38.2 & 42.5 \\
\hline $28 X-1,80-81$ & 253.60 & 24.91 & 1.15 & 4.83 & 1.43 & 1.67 & 31.16 & 2.04 & 0.45 & 0.06 & 0.34 & 2922 & 11.5 & 314 & 3.8 & 1322 & 39.4 & 42.7 & 44.5 \\
\hline $28 X-3,56-57$ & 256.36 & 52.24 & 2.27 & 9.75 & 5.14 & 3.08 & 13.61 & 3.52 & 0.81 & 0.11 & 0.54 & 6861 & 16.1 & 723 & 8.0 & 695.7 & 106.1 & 78.2 & 78.5 \\
\hline $29 \times-3,54-55$ & 264.45 & 23.10 & 0.83 & 4.17 & 1.71 & 1.52 & 33.75 & 1.54 & 0.41 & 0.04 & 0.28 & 4000 & 8.9 & 288 & 3.4 & 1523 & 43.2 & 37.0 & 39.2 \\
\hline $31 X-2,20-21$ & 283.50 & 7.04 & 0.34 & 1.23 & 0.21 & 0.66 & 39.82 & 0.69 & 0.21 & 0.02 & 0.29 & $\mathrm{BDL}$ & BDL & 107 & 1.4 & 1107 & BDL & 15.1 & 20.1 \\
\hline
\end{tabular}

Notes: $\mathrm{BDL}=$ below detection limit $\left(\mathrm{SiO}_{2}=3.5 \mathrm{wt} \%, \mathrm{Al}_{2} \mathrm{O}_{3}=0.04 \mathrm{wt} \%, \mathrm{Fe}_{2} \mathrm{O}_{3} \mathrm{~T}=0.003 \mathrm{wt} \%, \mathrm{MnO}=0.0004 \mathrm{wt} \%, \mathrm{MgO}=0.007 \mathrm{wt} \%, \mathrm{CaO}=0.1 \mathrm{wt} \%, \mathrm{Na} \mathrm{O}_{2} \mathrm{O}=0.02 \mathrm{wt} \%, \mathrm{~K}{ }_{2} \mathrm{O}=0.004 \mathrm{wt} \%\right.$, $\mathrm{TiO}_{2}=0.001$ wt $\%, \mathrm{P}_{2} \mathrm{O}_{5}=0.1 \mathrm{wt} \%, \mathrm{Ba}=28$ wt $\left.\%, \mathrm{Cr}=5 \mathrm{wt} \%, \mathrm{Cu}=16 \mathrm{wt} \%, \mathrm{Sc}=0.4 \mathrm{wt} \%, \mathrm{Sr}=3 \mathrm{wt} \%, \mathrm{~V}=4 \mathrm{wt} \%, \mathrm{Y}=1.7 \mathrm{wt} \%, \mathrm{Zr}=4 \mathrm{wt} \%\right)$. See Table T9 in the "Methods" chapter for maximum values of calibration. 
Table T26. Calcium carbonate and organic carbon data, Site U1334. (See table notes.) (Continued on next page.)

\begin{tabular}{|c|c|c|c|c|c|}
\hline \multirow{2}{*}{$\begin{array}{l}\text { Core, section, } \\
\text { interval }(\mathrm{cm})\end{array}$} & \multirow{2}{*}{$\begin{array}{l}\text { Depth } \\
\operatorname{CSF}(\mathrm{m})\end{array}$} & \multicolumn{4}{|c|}{ Carbon (wt\%) } \\
\hline & & $\mathrm{CaCO}_{3}$ & IC & $\mathrm{TC}$ & TOC \\
\hline \multicolumn{6}{|l|}{ 320-U1334A- } \\
\hline $1 \mathrm{H}-1,65-66$ & 0.65 & BDL & $\mathrm{BDL}$ & 0.20 & 0.15 \\
\hline $1 \mathrm{H}-2,65-66$ & 2.15 & BDL & $\mathrm{BDL}$ & ND & ND \\
\hline $1 \mathrm{H}-3,65-66$ & 3.65 & BDL & $\mathrm{BDL}$ & ND & ND \\
\hline $1 \mathrm{H}-4,65-66$ & 5.15 & $\mathrm{BDL}$ & $\mathrm{BDL}$ & ND & ND \\
\hline $1 \mathrm{H}-5,65-66$ & 6.65 & $\mathrm{BDL}$ & $\mathrm{BDL}$ & ND & ND \\
\hline $1 \mathrm{H}-6,20-21$ & 7.70 & BDL & BDL & ND & ND \\
\hline $2 \mathrm{H}-1,64-65$ & 8.84 & $\mathrm{BDL}$ & $\mathrm{BDL}$ & ND & ND \\
\hline $2 \mathrm{H}-2,64-65$ & 10.34 & BDL & BDL & 0.19 & 0.096 \\
\hline $2 \mathrm{H}-3,64-65$ & 11.84 & BDL & BDL & ND & ND \\
\hline $2 \mathrm{H}-4,64-65$ & 13.34 & $\mathrm{BDL}$ & $\mathrm{BDL}$ & ND & ND \\
\hline $2 \mathrm{H}-5,64-65$ & 14.84 & $\mathrm{BDL}$ & $\mathrm{BDL}$ & ND & ND \\
\hline $2 \mathrm{H}-6,64-65$ & 16.34 & $\mathrm{BDL}$ & $\mathrm{BDL}$ & ND & ND \\
\hline $2 \mathrm{H}-7,64-65$ & 17.84 & 59.9 & 7.20 & ND & ND \\
\hline $3 \mathrm{H}-1,65-66$ & 18.35 & 37.6 & 4.51 & 4.36 & 0.06 \\
\hline $3 \mathrm{H}-2,65-66$ & 19.85 & 27.6 & 3.32 & ND & ND \\
\hline $3 \mathrm{H}-3,65-66$ & 21.35 & 59.5 & 7.15 & ND & ND \\
\hline $3 \mathrm{H}-4,65-66$ & 22.85 & 30.3 & 3.64 & ND & ND \\
\hline $3 \mathrm{H}-5,65-66$ & 24.35 & 19.4 & 2.33 & ND & ND \\
\hline $3 \mathrm{H}-6,65-66$ & 25.85 & 20.0 & 2.41 & ND & ND \\
\hline $3 \mathrm{H}-7,30-31$ & 27.00 & 72.0 & 8.65 & ND & ND \\
\hline $4 \mathrm{H}-1,65-66$ & 27.85 & 33.7 & 4.05 & 4.07 & 0.05 \\
\hline $4 \mathrm{H}-2,65-66$ & 29.35 & 73.8 & 8.86 & ND & ND \\
\hline $4 \mathrm{H}-3,65-66$ & 30.85 & 20.9 & 2.51 & ND & ND \\
\hline $4 \mathrm{H}-4,65-66$ & 32.35 & 51.3 & 6.15 & ND & ND \\
\hline $4 \mathrm{H}-5,65-66$ & 33.85 & 12.7 & 1.53 & ND & ND \\
\hline $4 \mathrm{H}-6,65-66$ & 35.35 & 18.2 & 2.19 & ND & ND \\
\hline $4 \mathrm{H}-7,29-30$ & 36.49 & $\mathrm{BDL}$ & $\mathrm{BDL}$ & ND & ND \\
\hline $5 \mathrm{H}-1,65-66$ & 37.35 & 28.2 & 3.39 & ND & ND \\
\hline $5 \mathrm{H}-2,65-66$ & 38.85 & 3.4 & 0.41 & ND & ND \\
\hline $5 \mathrm{H}-3,65-66$ & 40.35 & 26.4 & 3.17 & ND & ND \\
\hline $5 \mathrm{H}-4,65-66$ & 41.85 & 54.9 & 6.60 & 6.19 & 0.05 \\
\hline $5 \mathrm{H}-5,65-66$ & 43.35 & 45.5 & 5.47 & ND & ND \\
\hline $5 \mathrm{H}-6,65-66$ & 44.85 & 65.8 & 7.90 & ND & ND \\
\hline $5 \mathrm{H}-7,55-56$ & 46.25 & 58.4 & 7.01 & ND & ND \\
\hline $6 \mathrm{H}-1,65-66$ & 46.85 & 89.1 & 10.69 & ND & ND \\
\hline $6 \mathrm{H}-2,65-66$ & 48.35 & 92.2 & 11.07 & 10.52 & BDL \\
\hline $6 \mathrm{H}-3,65-66$ & 49.85 & 87.9 & 10.55 & ND & ND \\
\hline $6 \mathrm{H}-4,65-66$ & 51.35 & 85.9 & 10.32 & ND & ND \\
\hline $6 \mathrm{H}-5,65-66$ & 52.85 & 85.4 & 10.25 & ND & ND \\
\hline $6 \mathrm{H}-6,65-66$ & 54.35 & 59.4 & 7.14 & ND & ND \\
\hline $7 \mathrm{H}-1,65-66$ & 56.35 & 78.6 & 9.43 & 9.49 & BDL \\
\hline $7 \mathrm{H}-2,65-66$ & 57.85 & 37.3 & 4.48 & ND & ND \\
\hline $7 \mathrm{H}-3,65-66$ & 59.35 & 76.7 & 9.21 & ND & ND \\
\hline $7 \mathrm{H}-4,65-66$ & 60.85 & 85.6 & 10.27 & ND & ND \\
\hline $7 \mathrm{H}-5,65-66$ & 62.35 & 74.7 & 8.96 & ND & ND \\
\hline $7 \mathrm{H}-6,65-66$ & 63.85 & 81.1 & 9.73 & ND & ND \\
\hline $7 \mathrm{H}-7,39-40$ & 65.09 & 88.7 & 10.65 & ND & ND \\
\hline $8 \mathrm{H}-2,65-66$ & 67.35 & 77.7 & 9.33 & 10.12 & BDL \\
\hline $8 \mathrm{H}-3,65-66$ & 68.85 & 91.1 & 10.93 & ND & ND \\
\hline $8 \mathrm{H}-4,65-66$ & 70.35 & 88.3 & 10.60 & ND & ND \\
\hline $8 \mathrm{H}-5,65-66$ & 71.85 & 91.6 & 10.99 & ND & ND \\
\hline $8 \mathrm{H}-6,65-66$ & 73.35 & 87.6 & 10.51 & ND & ND \\
\hline $8 \mathrm{H}-7,36-37$ & 74.56 & 87.9 & 10.56 & ND & ND \\
\hline $9 \mathrm{H}-1,75-76$ & 76.10 & 84.2 & 10.10 & 11.00 & 0.04 \\
\hline $9 \mathrm{H}-2,65-66$ & 76.85 & 84.3 & 10.12 & ND & ND \\
\hline $9 \mathrm{H}-3,65-66$ & 78.35 & 73.7 & 8.85 & ND & ND \\
\hline $9 \mathrm{H}-4,65-66$ & 79.85 & 82.4 & 9.90 & ND & ND \\
\hline $9 \mathrm{H}-5,65-66$ & 81.35 & 89.9 & 10.80 & ND & ND \\
\hline $9 \mathrm{H}-6,65-66$ & 82.85 & 88.7 & 10.65 & ND & ND \\
\hline $9 \mathrm{H}-7,55-56$ & 84.25 & 80.0 & 9.60 & ND & ND \\
\hline $10 \mathrm{H}-1,100-101$ & 85.20 & 82.7 & 9.92 & 10.71 & 0.04 \\
\hline $10 \mathrm{H}-2,65-66$ & 86.35 & 87.4 & 10.50 & ND & ND \\
\hline $10 \mathrm{H}-3,65-66$ & 87.85 & 68.2 & 8.18 & ND & ND \\
\hline $10 \mathrm{H}-4,65-66$ & 89.35 & 84.4 & 10.14 & ND & ND \\
\hline $10 \mathrm{H}-5,65-66$ & 90.85 & 84.1 & 10.10 & ND & ND \\
\hline $10 \mathrm{H}-6,65-66$ & 92.35 & 91.6 & 11.00 & ND & ND \\
\hline
\end{tabular}

\begin{tabular}{|c|c|c|c|c|c|}
\hline \multirow{2}{*}{$\begin{array}{l}\text { Core, section, } \\
\text { interval }(\mathrm{cm})\end{array}$} & \multirow{2}{*}{$\begin{array}{l}\text { Depth } \\
\text { CSF }(\mathrm{m})\end{array}$} & \multicolumn{4}{|c|}{ Carbon (wt\%) } \\
\hline & & $\mathrm{CaCO}_{3}$ & IC & $\mathrm{TC}$ & TOC \\
\hline $11 \mathrm{H}-1,77-78$ & 94.47 & 85.8 & 10.30 & 11.30 & 0.04 \\
\hline $11 \mathrm{H}-2,65-66$ & 95.85 & 88.5 & 10.63 & ND & ND \\
\hline $11 \mathrm{H}-3,65-66$ & 97.35 & 79.3 & 9.52 & ND & ND \\
\hline $11 \mathrm{H}-4,65-66$ & 98.85 & 79.4 & 9.53 & ND & ND \\
\hline $11 \mathrm{H}-5,65-66$ & 100.35 & 81.9 & 9.83 & ND & ND \\
\hline $11 \mathrm{H}-6,65-66$ & 101.85 & 79.0 & 9.49 & ND & ND \\
\hline $11 \mathrm{H}-7,29-30$ & 102.99 & 61.4 & 7.37 & ND & ND \\
\hline $12 \mathrm{H}-1,65-66$ & 103.85 & 82.8 & 9.93 & 10.14 & 0.03 \\
\hline $12 \mathrm{H}-2,65-66$ & 105.35 & 78.9 & 9.47 & ND & ND \\
\hline $12 \mathrm{H}-3,65-66$ & 106.85 & 78.9 & 9.47 & ND & ND \\
\hline $12 \mathrm{H}-4,65-66$ & 108.35 & 82.5 & 9.90 & ND & ND \\
\hline $12 \mathrm{H}-5,65-66$ & 109.85 & 84.2 & 10.11 & ND & ND \\
\hline $12 \mathrm{H}-6,65-66$ & 111.35 & 86.7 & 10.40 & ND & ND \\
\hline $12 \mathrm{H}-7,20-21$ & 112.17 & 79.3 & 9.52 & ND & ND \\
\hline $13 \mathrm{H}-2,65-66$ & 113.85 & 83.7 & 10.05 & ND & ND \\
\hline $13 \mathrm{H}-3,65-66$ & 115.35 & 88.5 & 10.62 & 10.15 & 0.04 \\
\hline $13 \mathrm{H}-4,65-66$ & 116.85 & 51.1 & 6.13 & ND & ND \\
\hline $13 \mathrm{H}-5,65-66$ & 118.35 & 82.2 & 9.87 & ND & ND \\
\hline $13 \mathrm{H}-6,65-66$ & 119.85 & 88.2 & 10.59 & ND & ND \\
\hline $13 \mathrm{H}-7,65-66$ & 121.35 & 85.8 & 10.30 & ND & ND \\
\hline $14 \mathrm{H}-1,65-66$ & 122.85 & 77.1 & 9.26 & 10.33 & 0.04 \\
\hline $14 \mathrm{H}-2,65-66$ & 124.35 & 79.8 & 9.58 & ND & ND \\
\hline $14 \mathrm{H}-3,65-66$ & 125.85 & 82.2 & 9.87 & ND & ND \\
\hline $14 \mathrm{H}-4,65-66$ & 127.35 & 79.9 & 9.59 & ND & ND \\
\hline $14 \mathrm{H}-5,65-66$ & 128.85 & 75.3 & 9.04 & ND & ND \\
\hline $14 \mathrm{H}-6,65-66$ & 130.35 & 84.8 & 10.18 & ND & ND \\
\hline $14 \mathrm{H}-7,25-26$ & 131.45 & 82.2 & 9.87 & ND & ND \\
\hline $15 \mathrm{H}-1,75-76$ & 132.45 & 92.5 & 11.10 & 11.23 & 0.04 \\
\hline $15 \mathrm{H}-2,65-66$ & 133.85 & 86.7 & 10.41 & ND & ND \\
\hline $15 \mathrm{H}-3,65-66$ & 135.35 & 79.2 & 9.50 & ND & ND \\
\hline $15 \mathrm{H}-4,65-66$ & 136.85 & 88.6 & 10.63 & ND & ND \\
\hline $15 \mathrm{H}-5,65-66$ & 138.35 & 89.1 & 10.70 & ND & ND \\
\hline $15 \mathrm{H}-6,45-46$ & 139.65 & 89.8 & 10.79 & ND & ND \\
\hline $15 \mathrm{H}-7,40-41$ & 140.60 & 82.8 & 9.94 & ND & ND \\
\hline $16 \mathrm{H}-1,74-75$ & 141.94 & 82.2 & 9.87 & 10.46 & 0.04 \\
\hline $16 \mathrm{H}-2,64-65$ & 143.34 & 92.3 & 11.08 & ND & ND \\
\hline $16 \mathrm{H}-3,64-65$ & 144.84 & 97.8 & 11.74 & ND & ND \\
\hline $16 \mathrm{H}-4,64-65$ & 146.34 & 86.0 & 10.32 & ND & ND \\
\hline $16 \mathrm{H}-5,64-65$ & 147.84 & 94.5 & 11.35 & ND & ND \\
\hline $16 \mathrm{H}-6,34-35$ & 149.04 & 89.0 & 10.69 & ND & ND \\
\hline $17 \mathrm{H}-1,65-66$ & 151.35 & 88.1 & 10.58 & 11.06 & 0.04 \\
\hline $17 \mathrm{H}-2,65-66$ & 152.85 & 75.9 & 9.11 & ND & ND \\
\hline $17 \mathrm{H}-3,65-66$ & 154.35 & 90.5 & 10.86 & ND & ND \\
\hline $17 \mathrm{H}-4,65-66$ & 155.85 & 90.5 & 10.87 & ND & ND \\
\hline $17 \mathrm{H}-5,65-66$ & 157.35 & 89.3 & 10.72 & ND & ND \\
\hline $17 \mathrm{H}-6,45-46$ & 158.65 & 93.2 & 11.19 & ND & ND \\
\hline $18 \mathrm{H}-2,65-66$ & 162.35 & 89.7 & 10.77 & 11.70 & 0.04 \\
\hline $18 \mathrm{H}-3,65-66$ & 163.85 & 93.9 & 11.27 & ND & ND \\
\hline $18 \mathrm{H}-4,65-66$ & 165.35 & 90.2 & 10.83 & ND & ND \\
\hline $18 \mathrm{H}-5,65-66$ & 166.85 & 87.7 & 10.53 & ND & ND \\
\hline $18 \mathrm{H}-6,65-66$ & 168.35 & 83.3 & 10.00 & ND & ND \\
\hline $18 \mathrm{H}-7,50-51$ & 169.60 & 88.0 & 10.56 & ND & ND \\
\hline $19 \mathrm{H}-1,65-66$ & 170.35 & 88.9 & 10.67 & 11.28 & 0.04 \\
\hline $19 \mathrm{H}-2,65-67$ & 171.77 & 87.2 & 10.46 & ND & ND \\
\hline $19 \mathrm{H}-3,65-67$ & 173.27 & 91.5 & 10.99 & ND & ND \\
\hline $19 \mathrm{H}-4,65-67$ & 174.77 & 86.2 & 10.35 & ND & ND \\
\hline $19 \mathrm{H}-5,65-67$ & 176.27 & 88.4 & 10.61 & ND & ND \\
\hline $19 \mathrm{H}-6,65-67$ & 177.77 & 89.0 & 10.68 & ND & ND \\
\hline $20 \mathrm{H}-1,65-67$ & 179.85 & 85.3 & 10.24 & 11.05 & 0.04 \\
\hline $20 \mathrm{H}-2,65-66$ & 181.35 & 86.0 & 10.32 & ND & ND \\
\hline $20 \mathrm{H}-3,65-66$ & 182.85 & 85.9 & 10.31 & ND & ND \\
\hline $20 \mathrm{H}-4,65-66$ & 184.35 & 85.1 & 10.22 & ND & ND \\
\hline $20 \mathrm{H}-5,65-66$ & 185.85 & 89.2 & 10.71 & ND & ND \\
\hline $20 \mathrm{H}-6,65-66$ & 187.35 & 90.2 & 10.82 & ND & ND \\
\hline $20 \mathrm{H}-7,20-21$ & 188.20 & 88.5 & 10.62 & ND & ND \\
\hline $21 \mathrm{H}-1,64-65$ & 189.34 & 92.0 & 11.04 & 11.13 & 0.03 \\
\hline $21 \mathrm{H}-2,64-65$ & 190.84 & 87.8 & 10.54 & ND & ND \\
\hline
\end{tabular}


Table T26 (continued).

\begin{tabular}{|c|c|c|c|c|c|}
\hline \multirow{2}{*}{$\begin{array}{l}\text { Core, section, } \\
\text { interval }(\mathrm{cm})\end{array}$} & \multirow{2}{*}{$\begin{array}{l}\text { Depth } \\
\text { CSF (m) }\end{array}$} & \multicolumn{4}{|c|}{ Carbon (wt\%) } \\
\hline & & $\mathrm{CaCO}_{3}$ & IC & $\mathrm{TC}$ & TOC \\
\hline $21 \mathrm{H}-3,64-65$ & 192.34 & 89.4 & 10.73 & ND & ND \\
\hline $21 \mathrm{H}-4,64-65$ & 193.84 & 95.4 & 11.45 & ND & ND \\
\hline $21 \mathrm{H}-5,64-65$ & 195.34 & 87.8 & 10.54 & ND & ND \\
\hline $21 \mathrm{H}-6,64-65$ & 196.84 & 88.4 & 10.61 & ND & ND \\
\hline $21 \mathrm{H}-7,9-10$ & 197.79 & 90.9 & 10.91 & ND & ND \\
\hline $22 \mathrm{H}-2,70-71$ & 200.40 & 89.1 & 10.69 & 11.71 & 0.04 \\
\hline $22 \mathrm{H}-3,65-66$ & 201.85 & 88.2 & 10.58 & ND & ND \\
\hline $22 \mathrm{H}-4,65-66$ & 203.35 & 92.1 & 11.06 & ND & ND \\
\hline $22 \mathrm{H}-5,65-66$ & 204.85 & 91.5 & 10.98 & ND & ND \\
\hline $22 \mathrm{H}-6,65-66$ & 206.35 & 75.0 & 9.00 & ND & ND \\
\hline $23 x-1,65-66$ & 207.55 & 83.7 & 10.04 & ND & ND \\
\hline $23 X-2,65-66$ & 209.05 & 77.0 & 9.24 & 10.15 & 0.03 \\
\hline $23 x-3,65-66$ & 210.55 & 77.6 & 9.31 & ND & ND \\
\hline $23 x-4,65-66$ & 212.05 & 79.8 & 9.57 & ND & ND \\
\hline $23 x-5,65-66$ & 213.55 & 84.9 & 10.19 & ND & ND \\
\hline $24 X-1,54-55$ & 215.04 & 84.4 & 10.13 & 10.42 & 0.04 \\
\hline $23 x-6,65-66$ & 215.05 & 85.4 & 10.25 & ND & ND \\
\hline $24 X-2,45-46$ & 216.45 & 80.6 & 9.68 & ND & ND \\
\hline $24 X-3,37-38$ & 217.87 & 77.1 & 9.26 & ND & ND \\
\hline $24 X-4,40-41$ & 219.40 & 76.4 & 9.17 & ND & ND \\
\hline $24 X-5,40-41$ & 220.90 & 83.7 & 10.04 & ND & ND \\
\hline $24 X-6,40-41$ & 222.40 & 81.8 & 9.82 & ND & ND \\
\hline $24 X-7,20-21$ & 223.70 & 82.1 & 9.85 & ND & ND \\
\hline $25 X-1,70-71$ & 224.80 & 61.9 & 7.43 & 9.57 & 0.04 \\
\hline $25 X-2,69-70$ & 226.29 & 69.9 & 8.39 & ND & ND \\
\hline $25 X-3,77-78$ & 227.87 & 67.2 & 8.06 & ND & ND \\
\hline $25 X-4,67-68$ & 229.27 & 67.4 & 8.09 & ND & ND \\
\hline $25 X-5,59-60$ & 230.69 & 71.8 & 8.62 & ND & ND \\
\hline $25 X-6,52-53$ & 232.12 & 68.9 & 8.27 & ND & ND \\
\hline $25 X-7,21-22$ & 233.31 & 73.4 & 8.81 & ND & ND \\
\hline $26 X-1,39-40$ & 233.99 & 65.1 & 7.81 & 8.65 & $\mathrm{BDL}$ \\
\hline $26 X-2,116-117$ & 236.26 & 78.0 & 9.36 & ND & ND \\
\hline $26 X-3,95-96$ & 237.55 & 79.6 & 9.56 & ND & ND \\
\hline
\end{tabular}

\begin{tabular}{|c|c|c|c|c|c|}
\hline \multirow{2}{*}{$\begin{array}{l}\text { Core, section, } \\
\text { interval }(\mathrm{cm})\end{array}$} & \multirow{2}{*}{$\begin{array}{l}\text { Depth } \\
\text { CSF (m) }\end{array}$} & \multicolumn{4}{|c|}{ Carbon (wt\%) } \\
\hline & & $\mathrm{CaCO}_{3}$ & IC & $\mathrm{TC}$ & TOC \\
\hline $26 X-4,89-90$ & 238.99 & 77.6 & 9.31 & ND & ND \\
\hline $26 X-5,60-61$ & 240.20 & 73.3 & 8.80 & ND & ND \\
\hline $26 x-6,63-63$ & 241.73 & 80.1 & 9.61 & ND & ND \\
\hline $27 X-1,119-120$ & 244.39 & 84.7 & 10.16 & ND & ND \\
\hline $27 X-2,77-78$ & 245.47 & 64.1 & 7.70 & 8.24 & 0.04 \\
\hline $27 X-3,90-91$ & 247.10 & 62.5 & 7.50 & ND & ND \\
\hline $27 X-4,90-91$ & 248.10 & 54.1 & 6.50 & ND & ND \\
\hline $27 X-5,90-91$ & 249.10 & 9.2 & 1.11 & 1.91 & 0.06 \\
\hline $27 X-6,9-10$ & 249.79 & 49.5 & 5.95 & ND & ND \\
\hline $27 X-C C, 41-42$ & 250.73 & 50.0 & 6.00 & ND & ND \\
\hline $28 X-1,80-81$ & 253.60 & 55.6 & 6.68 & ND & ND \\
\hline $28 X-2,123-124$ & 255.53 & BDL & $\mathrm{BDL}$ & 0.68 & 0.09 \\
\hline $28 X-3,56-57$ & 256.36 & 17.2 & 2.06 & ND & ND \\
\hline $28 X-4,41-42$ & 257.71 & 39.6 & 4.75 & ND & ND \\
\hline $28 X-5,65-66$ & 259.45 & 50.8 & 6.10 & 6.75 & $\mathrm{BDL}$ \\
\hline $28 X-6,55-56$ & 260.85 & 55.4 & 6.66 & ND & ND \\
\hline $28 X-7,19-20$ & 261.99 & 54.2 & 6.51 & ND & ND \\
\hline $29 X-1,53-55$ & 262.93 & 62.5 & 7.50 & 7.86 & 0.03 \\
\hline $29 X-3,54-55$ & 264.45 & 61.1 & 7.33 & ND & ND \\
\hline $29 X-4,84-86$ & 266.25 & 69.3 & 8.32 & ND & ND \\
\hline $29 X-5,76-78$ & 267.67 & 37.1 & 4.45 & ND & ND \\
\hline $29 X-6,47-49$ & 268.88 & 69.9 & 8.39 & ND & ND \\
\hline $29 X-7,70-72$ & 270.27 & 54.2 & 6.51 & ND & ND \\
\hline $29 X-8,42-44$ & 271.50 & 64.5 & 7.75 & ND & ND \\
\hline $30 x-1,78-79$ & 272.88 & 72.7 & 8.73 & 9.56 & 0.03 \\
\hline $30 x-2,77-78$ & 274.37 & 76.3 & 9.16 & ND & ND \\
\hline $30 X-3,83-84$ & 275.93 & 71.7 & 8.61 & ND & ND \\
\hline $30 X-4,83-84$ & 277.43 & 66.5 & 7.99 & ND & ND \\
\hline $30 X-5,103-104$ & 279.13 & 52.1 & 6.25 & ND & ND \\
\hline $30 X-6,46-47$ & 280.06 & 79.2 & 9.50 & ND & ND \\
\hline $30 x-7,41-42$ & 281.01 & 73.5 & 8.82 & ND & ND \\
\hline $31 X-1,65-66$ & 282.45 & 84.4 & 10.13 & 10.64 & 0.04 \\
\hline $31 X-2,20-21$ & 283.50 & 86.2 & 10.34 & ND & ND \\
\hline
\end{tabular}

Notes: IC = inorganic carbon, $\mathrm{TC}=$ total carbon, $\mathrm{TOC}=$ total organic carbon determined by acidification method. $\mathrm{BDL}=$ below detection limit $\left(\mathrm{CaCO}_{3}=<1 \mathrm{wt} \%, \mathrm{TOC}=<0.03 \mathrm{wt} \%\right)$ as determined by three times the standard deviation of replicate measures of a low concentration sample. $\mathrm{ND}=$ not determined. 
Table T27. Moisture and density measurements, Hole U1334A. (Continued on next page.)

\begin{tabular}{|c|c|c|c|c|c|c|}
\hline \multirow[b]{2}{*}{$\begin{array}{l}\text { Core, section, } \\
\text { interval }(\mathrm{cm})\end{array}$} & \multirow[b]{2}{*}{$\begin{array}{l}\text { Depth } \\
\text { CSF (m) }\end{array}$} & \multirow{2}{*}{$\begin{array}{l}\text { Water } \\
\text { content } \\
(\%)\end{array}$} & \multicolumn{3}{|c|}{ Density $\left(\mathrm{g} / \mathrm{cm}^{3}\right)$} & \multirow[b]{2}{*}{$\begin{array}{l}\text { Porosity } \\
(\%)\end{array}$} \\
\hline & & & $\begin{array}{l}\text { Wet } \\
\text { bulk }\end{array}$ & $\begin{array}{l}\text { Dry } \\
\text { bulk }\end{array}$ & Grain & \\
\hline \multicolumn{7}{|l|}{ 320-U1334A- } \\
\hline $1 \mathrm{H}-1,75-76$ & 0.75 & 79.4 & 1.19 & 0.25 & 3.23 & 92.4 \\
\hline $1 \mathrm{H}-2,75-76$ & 2.25 & 75.5 & 1.21 & 0.30 & 2.85 & 89.6 \\
\hline $1 \mathrm{H}-4,75-76$ & 5.25 & 75.2 & 1.22 & 0.30 & 2.85 & 89.4 \\
\hline $1 \mathrm{H}-5,75-76$ & 6.75 & 78.3 & 1.18 & 0.26 & 2.60 & 90.2 \\
\hline $1 \mathrm{H}-6,75-76$ & 8.25 & 76.6 & 1.20 & 0.28 & 2.81 & 90.0 \\
\hline $2 \mathrm{H}-1,75-76$ & 8.95 & 76.8 & 1.18 & 0.27 & 2.43 & 88.7 \\
\hline $2 \mathrm{H}-7,75-76$ & 17.95 & 56.8 & 1.42 & 0.61 & 2.89 & 78.8 \\
\hline $3 \mathrm{H}-1,75-76$ & 18.45 & 72.3 & 1.24 & 0.34 & 2.69 & 87.2 \\
\hline $3 \mathrm{H}-2,75-76$ & 19.95 & 74.9 & 1.21 & 0.30 & 2.57 & 88.2 \\
\hline $3 \mathrm{H}-3,75-76$ & 21.45 & 67.7 & 1.25 & 0.40 & 2.29 & 82.4 \\
\hline $3 \mathrm{H}-4,75-76$ & 22.95 & 66.9 & 1.34 & 0.44 & 3.59 & 87.6 \\
\hline $3 \mathrm{H}-5,75-76$ & 24.45 & 75.2 & 1.22 & 0.30 & 2.88 & 89.5 \\
\hline $3 \mathrm{H}-6,75-76$ & 25.95 & 72.7 & 1.22 & 0.33 & 2.56 & 86.9 \\
\hline $3 \mathrm{H}-7,75-76$ & 27.45 & 58.0 & 1.31 & 0.55 & 2.15 & 74.3 \\
\hline $4 \mathrm{H}-2,75-76$ & 29.45 & 55.6 & 1.42 & 0.63 & 2.75 & 77.1 \\
\hline $4 \mathrm{H}-3,75-76$ & 30.95 & 41.3 & 2.00 & 1.17 & 6.10 & 80.8 \\
\hline $4 \mathrm{H}-4,75-76$ & 32.45 & 60.9 & 1.29 & 0.50 & 2.15 & 76.6 \\
\hline $4 \mathrm{H}-5,75-76$ & 33.95 & 53.5 & 1.53 & 0.71 & 3.56 & 80.0 \\
\hline $4 \mathrm{H}-6,75-76$ & 35.45 & 76.7 & 1.20 & 0.28 & 2.77 & 89.9 \\
\hline $4 \mathrm{H}-7,75-76$ & 36.95 & 74.0 & 1.22 & 0.32 & 2.77 & 88.5 \\
\hline $5 \mathrm{H}-1,75-76$ & 37.45 & 66.1 & 1.28 & 0.44 & 2.54 & 82.8 \\
\hline $5 \mathrm{H}-3,75-76$ & 40.45 & 72.7 & 1.24 & 0.34 & 2.86 & 88.1 \\
\hline $5 \mathrm{H}-4,75-76$ & 41.95 & 69.8 & 1.27 & 0.38 & 2.80 & 86.4 \\
\hline $5 \mathrm{H}-6,75-76$ & 44.95 & 71.5 & 1.22 & 0.35 & 2.30 & 84.9 \\
\hline $5 \mathrm{H}-7,65-66$ & 46.35 & 55.0 & 1.44 & 0.65 & 2.85 & 77.3 \\
\hline $6 \mathrm{H}-1,75-76$ & 46.95 & 44.2 & 1.58 & 0.88 & 2.75 & 68.0 \\
\hline $6 \mathrm{H}-2,75-76$ & 48.45 & 44.9 & 1.52 & 0.84 & 2.53 & 66.8 \\
\hline $6 \mathrm{H}-3,75-76$ & 49.95 & 38.5 & 1.64 & 1.01 & 2.65 & 61.8 \\
\hline $6 \mathrm{H}-4,75-76$ & 51.45 & 42.2 & 1.61 & 0.93 & 2.78 & 66.5 \\
\hline $6 \mathrm{H}-5,75-76$ & 52.95 & 42.6 & 1.57 & 0.90 & 2.60 & 65.4 \\
\hline $6 \mathrm{H}-6,75-76$ & 54.45 & 56.1 & 1.38 & 0.61 & 2.47 & 75.4 \\
\hline $6 \mathrm{H}-7,55-56$ & 55.75 & 50.9 & 1.46 & 0.72 & 2.61 & 72.5 \\
\hline 7H-1, 110-111 & 56.80 & 57.8 & 1.38 & 0.58 & 2.64 & 77.9 \\
\hline $7 \mathrm{H}-4,75-76$ & 60.95 & 41.8 & 1.62 & 0.94 & 2.80 & 66.3 \\
\hline $7 \mathrm{H}-7,50-51$ & 65.20 & 37.5 & 1.72 & 1.07 & 2.89 & 62.8 \\
\hline $8 \mathrm{H}-1,120-121$ & 66.40 & 55.3 & 1.41 & 0.63 & 2.66 & 76.3 \\
\hline $8 \mathrm{H}-2,75-76$ & 67.45 & 49.3 & 1.50 & 0.76 & 2.76 & 72.4 \\
\hline $8 \mathrm{H}-3,75-76$ & 68.95 & 41.7 & 1.46 & 0.85 & 2.10 & 59.5 \\
\hline $8 \mathrm{H}-4,75-76$ & 70.45 & 50.0 & 1.51 & 0.75 & 2.85 & 73.6 \\
\hline $8 \mathrm{H}-5,75-76$ & 71.95 & 39.0 & 1.71 & 1.04 & 3.00 & 65.3 \\
\hline $8 \mathrm{H}-6,75-76$ & 73.45 & 44.7 & 1.60 & 0.88 & 2.91 & 69.7 \\
\hline $8 \mathrm{H}-7,45-46$ & 74.65 & 41.5 & 1.49 & 0.87 & 2.20 & 60.4 \\
\hline $9 \mathrm{H}-2,75-76$ & 76.95 & 46.3 & 1.55 & 0.83 & 2.80 & 70.2 \\
\hline $9 \mathrm{H}-3,75-76$ & 78.45 & 49.6 & 1.50 & 0.76 & 2.76 & 72.6 \\
\hline $9 \mathrm{H}-4,75-76$ & 79.95 & 43.9 & 1.42 & 0.80 & 2.04 & 60.9 \\
\hline $9 \mathrm{H}-5,75-76$ & 81.45 & 41.8 & 1.62 & 0.94 & 2.77 & 66.0 \\
\hline $9 \mathrm{H}-6,75-76$ & 82.95 & 37.3 & 1.71 & 1.07 & 2.86 & 62.5 \\
\hline $9 \mathrm{H}-7,65-75$ & 84.35 & 46.6 & 1.55 & 0.83 & 2.80 & 70.4 \\
\hline $10 \mathrm{H}-1,80-81$ & 85.00 & 46.2 & 1.54 & 0.83 & 2.71 & 69.4 \\
\hline $10 \mathrm{H}-2,75-76$ & 86.45 & 42.2 & 1.61 & 0.93 & 2.78 & 66.5 \\
\hline $10 \mathrm{H}-3,75-76$ & 87.95 & 53.4 & 1.45 & 0.67 & 2.75 & 75.5 \\
\hline $10 \mathrm{H}-4,75-76$ & 89.45 & 42.6 & 1.50 & 0.86 & 2.29 & 62.3 \\
\hline $10 \mathrm{H}-5,75-76$ & 90.95 & 42.4 & 1.57 & 0.91 & 2.60 & 65.2 \\
\hline $10 \mathrm{H}-6,75-76$ & 92.45 & 42.5 & 1.62 & 0.93 & 2.86 & 67.3 \\
\hline $11 \mathrm{H}-1,80-81$ & 94.50 & 45.2 & 1.47 & 0.80 & 2.28 & 64.8 \\
\hline $11 \mathrm{H}-2,75-76$ & 95.95 & 35.6 & 1.73 & 1.11 & 2.78 & 60.0 \\
\hline $11 \mathrm{H}-3,75-76$ & 97.45 & 43.2 & 1.61 & 0.91 & 2.85 & 67.9 \\
\hline $11 \mathrm{H}-4,75-76$ & 98.95 & 45.3 & 1.56 & 0.85 & 2.77 & 69.2 \\
\hline $11 \mathrm{H}-5,75-76$ & 100.45 & 42.6 & 1.69 & 0.97 & 3.25 & 70.2 \\
\hline $11 \mathrm{H}-7,40-41$ & 103.10 & 47.5 & 1.53 & 0.81 & 2.79 & 71.2 \\
\hline $12 \mathrm{H}-1,75-76$ & 103.95 & 42.9 & 1.60 & 0.91 & 2.78 & 67.1 \\
\hline $12 \mathrm{H}-2,75-76$ & 105.45 & 29.2 & 2.06 & 1.46 & 3.53 & 58.6 \\
\hline $12 \mathrm{H}-3,75-76$ & 106.95 & 43.9 & 1.59 & 0.89 & 2.81 & 68.2 \\
\hline $12 \mathrm{H}-4,75-76$ & 108.45 & 41.8 & 1.58 & 0.92 & 2.60 & 64.6 \\
\hline $12 \mathrm{H}-5,75-76$ & 109.95 & 40.2 & 1.66 & 0.99 & 2.83 & 65.0 \\
\hline $12 \mathrm{H}-6,75-76$ & 111.45 & 40.5 & 1.65 & 0.98 & 2.84 & 65.4 \\
\hline $12 \mathrm{H}-7,75-76$ & 112.72 & 38.9 & 1.66 & 1.01 & 2.73 & 63.0 \\
\hline
\end{tabular}

\begin{tabular}{|c|c|c|c|c|c|c|}
\hline \multirow[b]{2}{*}{$\begin{array}{l}\text { Core, section, } \\
\text { interval }(\mathrm{cm})\end{array}$} & \multirow[b]{2}{*}{$\begin{array}{l}\text { Depth } \\
\operatorname{CSF}(m)\end{array}$} & \multirow{2}{*}{$\begin{array}{l}\text { Water } \\
\text { content } \\
(\%)\end{array}$} & \multicolumn{3}{|c|}{ Density $\left(\mathrm{g} / \mathrm{cm}^{3}\right)$} & \multirow[b]{2}{*}{$\begin{array}{l}\text { Porosity } \\
\text { (\%) }\end{array}$} \\
\hline & & & $\begin{array}{l}\text { Wet } \\
\text { bulk }\end{array}$ & $\begin{array}{l}\text { Dry } \\
\text { bulk }\end{array}$ & Grain & \\
\hline $13 \mathrm{H}-3,75-76$ & 115.45 & 42.3 & 1.62 & 0.94 & 2.84 & 67.0 \\
\hline $13 \mathrm{H}-4,75-76$ & 116.95 & 52.0 & 1.44 & 0.69 & 2.56 & 73.0 \\
\hline $13 \mathrm{H}-5,75-76$ & 118.45 & 47.7 & 1.50 & 0.78 & 2.58 & 69.7 \\
\hline $13 \mathrm{H}-6,75-76$ & 119.95 & 36.8 & 1.72 & 1.09 & 2.84 & 61.7 \\
\hline $13 \mathrm{H}-7,75-76$ & 121.45 & 39.5 & 1.67 & 1.01 & 2.83 & 64.3 \\
\hline $13 \mathrm{H}-8,75-76$ & 122.45 & 49.6 & 1.52 & 0.76 & 2.90 & 73.6 \\
\hline $14 \mathrm{H}-1,75-76$ & 122.95 & 51.0 & 1.44 & 0.70 & 2.47 & 71.5 \\
\hline $14 \mathrm{H}-3,75-76$ & 125.95 & 45.4 & 1.57 & 0.86 & 2.80 & 69.4 \\
\hline $14 \mathrm{H}-5,75-76$ & 128.95 & 49.4 & 1.50 & 0.76 & 2.72 & 72.2 \\
\hline $14 \mathrm{H}-6,75-76$ & 130.45 & 39.6 & 1.68 & 1.01 & 2.88 & 64.9 \\
\hline $14 \mathrm{H}-7,35-36$ & 131.55 & 40.0 & 1.65 & 0.99 & 2.78 & 64.5 \\
\hline $15 \mathrm{H}-1,85-86$ & 132.55 & 38.5 & 1.66 & 1.02 & 2.71 & 62.4 \\
\hline $15 \mathrm{H}-2,75-76$ & 133.95 & 39.3 & 1.68 & 1.02 & 2.88 & 64.5 \\
\hline $15 \mathrm{H}-3,75-76$ & 135.45 & 44.4 & 1.59 & 0.88 & 2.84 & 68.9 \\
\hline $15 \mathrm{H}-4,75-76$ & 136.95 & 43.5 & 1.59 & 0.90 & 2.78 & 67.6 \\
\hline $15 \mathrm{H}-5,75-76$ & 138.45 & 39.9 & 1.66 & 1.00 & 2.81 & 64.6 \\
\hline $15 \mathrm{H}-6,55-56$ & 139.75 & 37.8 & 1.75 & 1.09 & 3.07 & 64.5 \\
\hline $15 \mathrm{H}-7,50-51$ & 140.70 & 43.7 & 1.59 & 0.89 & 2.78 & 67.8 \\
\hline $16 \mathrm{H}-1,85-86$ & 142.05 & 42.4 & 1.61 & 0.93 & 2.80 & 66.8 \\
\hline $16 \mathrm{H}-2,75-76$ & 143.45 & 32.3 & 1.82 & 1.23 & 2.90 & 57.4 \\
\hline $16 \mathrm{H}-3,75-76$ & 144.95 & 34.6 & 1.77 & 1.16 & 2.86 & 59.7 \\
\hline $16 \mathrm{H}-4,75-76$ & 146.45 & 40.6 & 1.67 & 0.99 & 2.93 & 66.2 \\
\hline $16 \mathrm{H}-5,75-76$ & 147.95 & 38.3 & 1.70 & 1.05 & 2.88 & 63.6 \\
\hline $16 \mathrm{H}-6,45-46$ & 149.15 & 30.0 & 1.85 & 1.29 & 2.82 & 54.1 \\
\hline $17 \mathrm{H}-1,75-76$ & 151.45 & 37.8 & 1.70 & 1.06 & 2.86 & 62.9 \\
\hline $17 \mathrm{H}-2,75-76$ & 152.95 & 39.7 & 1.68 & 1.01 & 2.89 & 65.0 \\
\hline $17 \mathrm{H}-3,75-76$ & 154.45 & 36.9 & 1.73 & 1.10 & 2.92 & 62.5 \\
\hline $17 \mathrm{H}-5,75-76$ & 157.45 & 41.4 & 1.64 & 0.96 & 2.86 & 66.3 \\
\hline $17 \mathrm{H}-6,55-56$ & 158.75 & 35.3 & 1.75 & 1.13 & 2.84 & 60.2 \\
\hline $18 \mathrm{H}-2,75-76$ & 162.45 & 38.4 & 1.64 & 1.01 & 2.63 & 61.6 \\
\hline $18 \mathrm{H}-3,75-76$ & 163.95 & 37.3 & 1.72 & 1.08 & 2.86 & 62.4 \\
\hline $18 \mathrm{H}-4,75-76$ & 165.45 & 36.0 & 1.72 & 1.10 & 2.78 & 60.4 \\
\hline $18 \mathrm{H}-5,75-76$ & 166.95 & 34.0 & 1.70 & 1.12 & 2.58 & 56.5 \\
\hline $18 \mathrm{H}-6,75-76$ & 168.45 & 42.0 & 1.64 & 0.95 & 2.90 & 67.2 \\
\hline $18 \mathrm{H}-7,60-61$ & 169.70 & 37.7 & 1.70 & 1.06 & 2.85 & 62.8 \\
\hline $19 \mathrm{H}-1,80-81$ & 170.50 & 36.0 & 1.69 & 1.08 & 2.65 & 59.3 \\
\hline $19 \mathrm{H}-2,75-76$ & 171.87 & 36.0 & 1.74 & 1.11 & 2.87 & 61.2 \\
\hline $19 \mathrm{H}-3,75-76$ & 173.37 & 37.8 & 1.71 & 1.06 & 2.87 & 63.0 \\
\hline $19 \mathrm{H}-4,75-76$ & 174.87 & 39.7 & 1.60 & 0.96 & 2.53 & 61.9 \\
\hline $19 \mathrm{H}-5,75-76$ & 176.37 & 38.6 & 1.68 & 1.03 & 2.82 & 63.3 \\
\hline $19 \mathrm{H}-6,75-76$ & 177.87 & 40.2 & 1.65 & 0.99 & 2.82 & 64.9 \\
\hline $20 \mathrm{H}-3,75-76$ & 182.95 & 39.7 & 1.60 & 0.96 & 2.54 & 62.0 \\
\hline $20 \mathrm{H}-4,75-76$ & 184.45 & 44.6 & 1.48 & 0.82 & 2.32 & 64.6 \\
\hline $20 \mathrm{H}-5,75-76$ & 185.95 & 37.6 & 1.70 & 1.06 & 2.81 & 62.3 \\
\hline $20 \mathrm{H}-6,75-76$ & 187.45 & 38.6 & 1.68 & 1.03 & 2.81 & 63.4 \\
\hline $21 \mathrm{H}-1,75-76$ & 189.45 & 35.4 & 1.79 & 1.16 & 3.04 & 61.9 \\
\hline $21 \mathrm{H}-2,75-76$ & 190.95 & 36.5 & 1.71 & 1.09 & 2.80 & 61.1 \\
\hline $21 \mathrm{H}-3,75-76$ & 192.45 & 29.4 & 1.87 & 1.32 & 2.85 & 53.7 \\
\hline $21 \mathrm{H}-4,75-76$ & 193.95 & 36.6 & 1.72 & 1.09 & 2.81 & 61.3 \\
\hline $21 \mathrm{H}-5,75-76$ & 195.45 & 34.6 & 1.78 & 1.16 & 2.92 & 60.2 \\
\hline $21 \mathrm{H}-6,75-76$ & 196.95 & 35.2 & 1.67 & 1.08 & 2.53 & 57.3 \\
\hline $21 \mathrm{H}-7,75-76$ & 198.45 & 38.1 & 1.70 & 1.05 & 2.87 & 63.3 \\
\hline $22 \mathrm{H}-2,75-76$ & 200.45 & 37.6 & 1.71 & 1.07 & 2.87 & 62.9 \\
\hline $22 \mathrm{H}-3,75-76$ & 201.95 & 37.9 & 1.62 & 1.01 & 2.51 & 60.0 \\
\hline $22 \mathrm{H}-4,75-76$ & 203.45 & 34.6 & 1.77 & 1.15 & 2.86 & 59.7 \\
\hline $22 \mathrm{H}-5,75-76$ & 204.95 & 43.6 & 1.53 & 0.86 & 2.46 & 65.0 \\
\hline $22 \mathrm{H}-6,75-76$ & 206.45 & 42.5 & 1.55 & 0.89 & 2.48 & 64.1 \\
\hline $23 X-2,75-76$ & 209.15 & 47.6 & 1.55 & 0.81 & 2.87 & 71.8 \\
\hline $23 X-4,75-76$ & 212.15 & 41.7 & 1.69 & 0.98 & 3.15 & 68.8 \\
\hline $23 X-5,75-76$ & 213.65 & 60.8 & 1.26 & 0.50 & 1.97 & 74.9 \\
\hline $23 X-6,70-71$ & 215.10 & 40.7 & 1.63 & 0.96 & 2.73 & 64.6 \\
\hline $24 \mathrm{X}-1,64-65$ & 215.14 & 35.2 & 1.84 & 1.19 & 3.26 & 63.4 \\
\hline $24 \mathrm{X}-2,54-55$ & 216.54 & 39.7 & 1.68 & 1.01 & 2.89 & 65.0 \\
\hline $24 X-4,50-51$ & 219.50 & 38.2 & 1.71 & 1.06 & 2.94 & 64.0 \\
\hline $24 X-5,50-51$ & 221.00 & 1.7 & 2.73 & 2.69 & 2.81 & 4.5 \\
\hline $24 X-6,50-51$ & 222.50 & 48.3 & 1.44 & 0.74 & 2.30 & 67.7 \\
\hline $25 X-1,80-81$ & 224.90 & 33.7 & 1.74 & 1.15 & 2.71 & 57.4 \\
\hline $25 X-3,90-91$ & 228.00 & 43.1 & 1.61 & 0.91 & 2.82 & 67.6 \\
\hline
\end{tabular}


Table T27 (continued).

\begin{tabular}{|c|c|c|c|c|c|c|}
\hline \multirow[b]{2}{*}{$\begin{array}{l}\text { Core, section, } \\
\text { interval }(\mathrm{cm})\end{array}$} & \multirow[b]{2}{*}{$\begin{array}{l}\text { Depth } \\
\text { CSF }(m)\end{array}$} & \multirow{2}{*}{$\begin{array}{l}\text { Water } \\
\text { content } \\
(\%)\end{array}$} & \multicolumn{3}{|c|}{ Density $\left(\mathrm{g} / \mathrm{cm}^{3}\right)$} & \multirow[b]{2}{*}{$\begin{array}{c}\text { Porosity } \\
\text { (\%) }\end{array}$} \\
\hline & & & $\begin{array}{l}\text { Wet } \\
\text { bulk }\end{array}$ & $\begin{array}{l}\text { Dry } \\
\text { bulk }\end{array}$ & Grain & \\
\hline $25 X-5,69-70$ & 230.79 & 33.7 & 1.87 & 1.24 & 3.21 & 61.4 \\
\hline $25 X-6,61-62$ & 232.21 & 49.3 & 1.45 & 0.74 & 2.43 & 69.8 \\
\hline $25 X-7,29-30$ & 233.39 & 23.9 & 1.95 & 1.49 & 2.73 & 45.5 \\
\hline $26 X-1,50-51$ & 234.10 & 38.6 & 1.62 & 0.99 & 2.55 & 61.0 \\
\hline $26 X-2,127-128$ & 236.37 & 39.8 & 1.68 & 1.01 & 2.89 & 65.1 \\
\hline $26 X-3,106-107$ & 237.66 & 39.9 & 1.72 & 1.04 & 3.14 & 67.1 \\
\hline $26 X-4,98-99$ & 239.08 & 40.9 & 1.55 & 0.91 & 2.39 & 61.8 \\
\hline $26 X-5,69-70$ & 240.29 & 42.8 & 1.60 & 0.92 & 2.77 & 67.0 \\
\hline $26 X-6,70-71$ & 241.80 & 38.6 & 1.75 & 1.08 & 3.16 & 66.0 \\
\hline $27 X-1,119-120$ & 244.39 & 36.7 & 1.93 & 1.22 & 3.98 & 69.2 \\
\hline $27 X-2,77-78$ & 245.47 & 46.6 & 1.58 & 0.85 & 3.03 & 72.1 \\
\hline $28 X-1,91-92$ & 253.71 & 48.9 & 1.41 & 0.72 & 2.21 & 67.4 \\
\hline $28 X-3,67-68$ & 256.47 & 61.1 & 1.35 & 0.53 & 2.73 & 80.8 \\
\hline $28 X-4,52-53$ & 257.82 & 57.1 & 1.40 & 0.60 & 2.74 & 78.1 \\
\hline $28 X-5,74-75$ & 259.54 & 46.7 & 1.45 & 0.77 & 2.28 & 66.1 \\
\hline $28 X-6,65-66$ & 260.95 & 43.4 & 1.59 & 0.90 & 2.75 & 67.3 \\
\hline $28 X-7,29-30$ & 262.09 & 49.5 & 1.49 & 0.75 & 2.67 & 71.9 \\
\hline $29 X-5,70-71$ & 267.61 & 55.2 & 1.46 & 0.65 & 3.09 & 78.8 \\
\hline $29 X-7,52-53$ & 270.09 & 47.7 & 1.60 & 0.84 & 3.24 & 74.3 \\
\hline $30 \times-2,76-77$ & 274.36 & 37.7 & 1.70 & 1.06 & 2.84 & 62.6 \\
\hline
\end{tabular}


Table T28. Split-core $P$-wave velocity measurements, Hole U1334A. (Continued on next page.)

\begin{tabular}{|c|c|c|c|c|}
\hline \multirow{2}{*}{$\begin{array}{l}\text { Core, } \\
\text { section }\end{array}$} & \multirow{2}{*}{$\begin{array}{c}\text { Depth } \\
\text { CSF }(\mathrm{m})\end{array}$} & \multicolumn{3}{|c|}{ Velocity $(\mathrm{m} / \mathrm{s})$} \\
\hline & & $x$-axis & $y$-axis & $z$-axis \\
\hline \multicolumn{5}{|c|}{ 320-U1334A- } \\
\hline $1 \mathrm{H}-1$ & 1.38 & & 1510 & 1503 \\
\hline $1 \mathrm{H}-1$ & 1.46 & 1551 & & \\
\hline $1 \mathrm{H}-2$ & 2.82 & & 1511 & 1503 \\
\hline $1 \mathrm{H}-2$ & 2.90 & 1559 & & \\
\hline $1 \mathrm{H}-3$ & 4.35 & & & 1500 \\
\hline $1 \mathrm{H}-3$ & 4.45 & 1563 & & \\
\hline $1 \mathrm{H}-4$ & 5.91 & 1574 & & \\
\hline $1 \mathrm{H}-5$ & 7.37 & & & 1513 \\
\hline $1 \mathrm{H}-5$ & 7.45 & 1579 & & \\
\hline $2 \mathrm{H}-1$ & 9.55 & & & 1521 \\
\hline $2 \mathrm{H}-1$ & 9.65 & 1601 & & \\
\hline $2 \mathrm{H}-2$ & 11.04 & & 1521 & 1512 \\
\hline $2 \mathrm{H}-2$ & 11.11 & 1586 & & \\
\hline $2 \mathrm{H}-3$ & 12.59 & & & 1473 \\
\hline $2 \mathrm{H}-3$ & 12.65 & 1590 & & \\
\hline $2 \mathrm{H}-4$ & 14.08 & & 1525 & 1446 \\
\hline $2 \mathrm{H}-4$ & 14.15 & 1577 & & \\
\hline $2 \mathrm{H}-5$ & 15.52 & & 1523 & 1480 \\
\hline $2 \mathrm{H}-5$ & 15.60 & 1585 & & \\
\hline $2 \mathrm{H}-6$ & 17.08 & & 1498 & 1495 \\
\hline $2 \mathrm{H}-6$ & 17.15 & 1565 & & \\
\hline $3 \mathrm{H}-1$ & 19.15 & 1580 & & \\
\hline $3 \mathrm{H}-2$ & 20.60 & 1444 & & \\
\hline $3 \mathrm{H}-3$ & 22.07 & & 1414 & 1424 \\
\hline $3 \mathrm{H}-3$ & 22.15 & 1585 & & \\
\hline $3 \mathrm{H}-4$ & 23.65 & 1583 & & \\
\hline $3 \mathrm{H}-5$ & 24.91 & & 1436 & \\
\hline $3 \mathrm{H}-5$ & 25.10 & 1583 & & \\
\hline $3 \mathrm{H}-6$ & 26.56 & & 1518 & 1515 \\
\hline $3 \mathrm{H}-6$ & 26.67 & 1557 & & \\
\hline $4 \mathrm{H}-1$ & 28.65 & 1592 & & \\
\hline $4 \mathrm{H}-2$ & 30.10 & 1599 & & \\
\hline $4 \mathrm{H}-3$ & 31.58 & & 1447 & 1445 \\
\hline $4 \mathrm{H}-3$ & 31.65 & 1646 & & \\
\hline $4 \mathrm{H}-4$ & 33.15 & 1554 & & \\
\hline $4 \mathrm{H}-5$ & 34.53 & & & 1507 \\
\hline $4 \mathrm{H}-5$ & 34.61 & 1571 & & \\
\hline $4 \mathrm{H}-6$ & 35.95 & & 1435 & \\
\hline $4 \mathrm{H}-6$ & 36.11 & 1574 & & \\
\hline $5 \mathrm{H}-1$ & 38.16 & 1537 & & \\
\hline $5 \mathrm{H}-4$ & 41.20 & & 1520 & \\
\hline $5 \mathrm{H}-4$ & 42.58 & & 1520 & \\
\hline $5 \mathrm{H}-4$ & 42.67 & 1575 & & \\
\hline $5 \mathrm{H}-5$ & 44.02 & & 1512 & 1461 \\
\hline $5 \mathrm{H}-5$ & 44.10 & 1579 & & \\
\hline $5 \mathrm{H}-6$ & 45.55 & & & 1511 \\
\hline $5 \mathrm{H}-6$ & 45.65 & 1573 & & \\
\hline $6 \mathrm{H}-1$ & 47.55 & & & \\
\hline $6 \mathrm{H}-1$ & 47.65 & 1562 & & \\
\hline $6 \mathrm{H}-2$ & 49.02 & & & 1500 \\
\hline $6 \mathrm{H}-2$ & 49.10 & 1575 & & \\
\hline $6 \mathrm{H}-3$ & 50.54 & & 1509 & 1507 \\
\hline $6 \mathrm{H}-3$ & 50.63 & 1594 & & \\
\hline $6 \mathrm{H}-4$ & 52.05 & & & 1502 \\
\hline $6 \mathrm{H}-4$ & 52.15 & 1580 & & \\
\hline $6 \mathrm{H}-5$ & 53.47 & & 1507 & 1499 \\
\hline $6 \mathrm{H}-5$ & 53.59 & 1585 & & \\
\hline $6 \mathrm{H}-6$ & 55.07 & & & 1457 \\
\hline $6 \mathrm{H}-6$ & 55.15 & 1585 & & \\
\hline $7 \mathrm{H}-1$ & 57.06 & & 2347 & \\
\hline $7 \mathrm{H}-1$ & 57.15 & 1563 & & \\
\hline $7 \mathrm{H}-2$ & 58.56 & & 1419 & \\
\hline $7 \mathrm{H}-2$ & 58.65 & 1563 & & \\
\hline $7 \mathrm{H}-3$ & 59.96 & & 1400 & 1500 \\
\hline $7 \mathrm{H}-3$ & 60.05 & 1574 & & \\
\hline $7 \mathrm{H}-4$ & 61.55 & & 1405 & 1507 \\
\hline $7 \mathrm{H}-4$ & 61.65 & 1569 & & \\
\hline
\end{tabular}

\begin{tabular}{|c|c|c|c|c|}
\hline \multirow{2}{*}{$\begin{array}{l}\text { Core, } \\
\text { section }\end{array}$} & \multirow{2}{*}{$\begin{array}{c}\text { Depth } \\
\text { CSF }(\mathrm{m})\end{array}$} & \multicolumn{3}{|c|}{ Velocity $(\mathrm{m} / \mathrm{s})$} \\
\hline & & $x$-axis & $y$-axis & $z$-axis \\
\hline $7 \mathrm{H}-5$ & 63.04 & & 1433 & \\
\hline $7 \mathrm{H}-5$ & 63.15 & 1566 & & \\
\hline $7 \mathrm{H}-6$ & 64.54 & & & 1501 \\
\hline $7 \mathrm{H}-6$ & 64.65 & 1579 & & \\
\hline $8 \mathrm{H}-2$ & 68.04 & & & \\
\hline $8 \mathrm{H}-2$ & 68.15 & 1532 & & \\
\hline $8 \mathrm{H}-3$ & 69.54 & 1547 & & \\
\hline $8 \mathrm{H}-4$ & 71.05 & & 1405 & 1503 \\
\hline $8 \mathrm{H}-4$ & 71.15 & 2773 & & \\
\hline $8 \mathrm{H}-5$ & 72.41 & & 2361 & 1509 \\
\hline $8 \mathrm{H}-5$ & 72.55 & & 1509 & 1507 \\
\hline $8 \mathrm{H}-5$ & 72.65 & 1570 & & \\
\hline $8 \mathrm{H}-6$ & 74.15 & 1545 & & \\
\hline $9 \mathrm{H}-1$ & 76.15 & 1540 & & \\
\hline $9 \mathrm{H}-2$ & 77.57 & & & 1502 \\
\hline $9 \mathrm{H}-2$ & 77.65 & 1536 & & \\
\hline $9 \mathrm{H}-3$ & 79.05 & 1542 & & \\
\hline $9 \mathrm{H}-4$ & 80.56 & & 1521 & 1511 \\
\hline $9 \mathrm{H}-4$ & 80.65 & 1557 & & \\
\hline $9 \mathrm{H}-5$ & 82.05 & & 1510 & 1509 \\
\hline $9 \mathrm{H}-5$ & 82.29 & 1567 & & \\
\hline $9 \mathrm{H}-6$ & 83.55 & & & 1511 \\
\hline $9 \mathrm{H}-6$ & 83.65 & 1563 & & \\
\hline $10 \mathrm{H}-1$ & 85.65 & 1563 & & \\
\hline $10 \mathrm{H}-2$ & 87.15 & 1577 & & \\
\hline $10 \mathrm{H}-3$ & 88.48 & & 1527 & 1426 \\
\hline $10 \mathrm{H}-4$ & 88.56 & 1601 & & \\
\hline $10 \mathrm{H}-4$ & 90.15 & 1544 & & \\
\hline $10 \mathrm{H}-5$ & 91.65 & 1564 & & \\
\hline $10 \mathrm{H}-6$ & 93.08 & & 1517 & 1514 \\
\hline $10 \mathrm{H}-6$ & 93.15 & 1563 & & \\
\hline $11 \mathrm{H}-1$ & 95.14 & 1564 & & \\
\hline $11 \mathrm{H}-2$ & 96.65 & 1573 & & \\
\hline $11 \mathrm{H}-3$ & 97.97 & & 1504 & 1503 \\
\hline $11 \mathrm{H}-3$ & 98.04 & 1572 & & \\
\hline $11 \mathrm{H}-4$ & 99.58 & & 1507 & 1771 \\
\hline $11 \mathrm{H}-4$ & 99.65 & 1568 & & \\
\hline $11 \mathrm{H}-5$ & 101.05 & & 1515 & 1506 \\
\hline $11 \mathrm{H}-5$ & 101.15 & 1570 & & \\
\hline $12 \mathrm{H}-1$ & 104.57 & & & 1453 \\
\hline $12 \mathrm{H}-1$ & 104.65 & 1544 & & \\
\hline $12 \mathrm{H}-2$ & 106.06 & & 1403 & \\
\hline $12 \mathrm{H}-2$ & 106.15 & 1575 & & \\
\hline $12 \mathrm{H}-3$ & 107.45 & & 1504 & 1507 \\
\hline $12 \mathrm{H}-3$ & 107.55 & 1565 & & \\
\hline $12 \mathrm{H}-4$ & 109.07 & & 1410 & 1504 \\
\hline $12 \mathrm{H}-4$ & 109.14 & 1565 & & \\
\hline $12 \mathrm{H}-5$ & 110.54 & & 1522 & 1449 \\
\hline $12 \mathrm{H}-5$ & 110.65 & 1572 & & \\
\hline $12 \mathrm{H}-6$ & 111.93 & 1546 & & \\
\hline $12 \mathrm{H}-6$ & 112.06 & & 1511 & \\
\hline $13 \mathrm{H}-2$ & 114.57 & & 1511 & 1506 \\
\hline $13 \mathrm{H}-2$ & 114.64 & 1550 & & \\
\hline $13 \mathrm{H}-3$ & 116.06 & & 1515 & 1506 \\
\hline $13 \mathrm{H}-3$ & 116.14 & 1557 & & \\
\hline $13 \mathrm{H}-4$ & 117.46 & & & \\
\hline $13 \mathrm{H}-4$ & 117.54 & 1541 & & \\
\hline $13 \mathrm{H}-5$ & 119.06 & & 1531 & 1509 \\
\hline $13 \mathrm{H}-5$ & 119.15 & 1557 & & \\
\hline $13 \mathrm{H}-6$ & 120.55 & & 1518 & 1508 \\
\hline $13 \mathrm{H}-6$ & 120.65 & 1559 & & \\
\hline $14 \mathrm{H}-2$ & 125.05 & & 1523 & 1516 \\
\hline $14 \mathrm{H}-3$ & 126.43 & & & 1505 \\
\hline $14 \mathrm{H}-3$ & 126.54 & 2655 & & \\
\hline $14 \mathrm{H}-4$ & 128.04 & & 1523 & 1459 \\
\hline $14 \mathrm{H}-4$ & 128.14 & 1559 & & \\
\hline $14 \mathrm{H}-5$ & 129.55 & & 1523 & 1509 \\
\hline $14 \mathrm{H}-5$ & 129.65 & 1562 & & \\
\hline
\end{tabular}


Table T28 (continued).

\begin{tabular}{|c|c|c|c|c|}
\hline \multirow{2}{*}{$\begin{array}{l}\text { Core, } \\
\text { section }\end{array}$} & \multirow{2}{*}{$\begin{array}{c}\text { Depth } \\
\text { CSF }(m)\end{array}$} & \multicolumn{3}{|c|}{ Velocity $(\mathrm{m} / \mathrm{s})$} \\
\hline & & $x$-axis & $y$-axis & $z$-axis \\
\hline $14 \mathrm{H}-6$ & 131.03 & & 1516 & 1506 \\
\hline $14 \mathrm{H}-6$ & 131.12 & 1566 & & \\
\hline $15 \mathrm{H}-2$ & 134.65 & 1587 & & \\
\hline $15 \mathrm{H}-3$ & 136.04 & 1543 & & \\
\hline $15 \mathrm{H}-4$ & 137.55 & & 1434 & \\
\hline $15 \mathrm{H}-4$ & 137.65 & 1553 & & \\
\hline $15 \mathrm{H}-5$ & 139.04 & & 1529 & 1511 \\
\hline $15 \mathrm{H}-5$ & 139.15 & 1560 & & \\
\hline $15 \mathrm{H}-6$ & 140.06 & & 1527 & 1509 \\
\hline $15 \mathrm{H}-6$ & 140.14 & 1557 & & \\
\hline $16 \mathrm{H}-1$ & 142.55 & & 1521 & 1512 \\
\hline $16 \mathrm{H}-1$ & 142.65 & 1570 & & \\
\hline $16 \mathrm{H}-2$ & 144.05 & & 1526 & 1510 \\
\hline $16 \mathrm{H}-2$ & 144.14 & 1554 & & \\
\hline $16 \mathrm{H}-3$ & 145.46 & & 1534 & \\
\hline $16 \mathrm{H}-3$ & 145.56 & 2687 & & \\
\hline $16 \mathrm{H}-4$ & 147.07 & & & 1517 \\
\hline $16 \mathrm{H}-4$ & 147.15 & 1561 & & \\
\hline $16 \mathrm{H}-5$ & 148.56 & & 1543 & 1465 \\
\hline $16 \mathrm{H}-5$ & 148.65 & 1560 & & \\
\hline $17 \mathrm{H}-1$ & 152.07 & & 1441 & \\
\hline $17 \mathrm{H}-1$ & 152.15 & 1546 & & \\
\hline $17 \mathrm{H}-2$ & 153.55 & & 1440 & 1465 \\
\hline $17 \mathrm{H}-2$ & 153.64 & 1549 & & \\
\hline $17 \mathrm{H}-3$ & 154.98 & & 1541 & 1523 \\
\hline $17 \mathrm{H}-3$ & 155.04 & 1546 & & \\
\hline $17 \mathrm{H}-4$ & 156.35 & & 1552 & 1520 \\
\hline $17 \mathrm{H}-4$ & 156.44 & 1544 & & \\
\hline $17 \mathrm{H}-5$ & 157.96 & & 1541 & \\
\hline $17 \mathrm{H}-5$ & 158.04 & 1589 & & \\
\hline $18 \mathrm{H}-2$ & 163.05 & & 1408 & \\
\hline $18 \mathrm{H}-2$ & 163.14 & 1546 & & \\
\hline $18 \mathrm{H}-3$ & 164.46 & & 1528 & \\
\hline $18 \mathrm{H}-3$ & 164.54 & 1579 & & \\
\hline $18 \mathrm{H}-4$ & 166.05 & & 1560 & 1471 \\
\hline $18 \mathrm{H}-4$ & 166.14 & 1566 & & \\
\hline $18 \mathrm{H}-5$ & 167.56 & & 1553 & 1522 \\
\hline $18 \mathrm{H}-5$ & 167.65 & 1563 & & \\
\hline $18 \mathrm{H}-6$ & 168.97 & & & 1471 \\
\hline $18 \mathrm{H}-6$ & 169.05 & 1572 & & \\
\hline $19 \mathrm{H}-1$ & 171.08 & 1565 & & \\
\hline $19 \mathrm{H}-2$ & 172.71 & 1550 & & \\
\hline $19 \mathrm{H}-3$ & 173.91 & & 1548 & 1517 \\
\hline $19 \mathrm{H}-3$ & 173.98 & 1545 & & \\
\hline $19 \mathrm{H}-4$ & 175.51 & & 1549 & 1519 \\
\hline $19 \mathrm{H}-4$ & 175.58 & 1558 & & \\
\hline $19 \mathrm{H}-5$ & 176.99 & & 1436 & \\
\hline $19 \mathrm{H}-5$ & 177.08 & 1553 & & \\
\hline $20 \mathrm{H}-1$ & 180.67 & 1569 & & \\
\hline $20 \mathrm{H}-2$ & 182.07 & & 1549 & 1473 \\
\hline $20 \mathrm{H}-2$ & 182.15 & 1542 & & \\
\hline $20 \mathrm{H}-3$ & 183.48 & & 1427 & \\
\hline $20 \mathrm{H}-3$ & 183.57 & 1564 & & \\
\hline $20 \mathrm{H}-4$ & 185.07 & & 1552 & \\
\hline $20 \mathrm{H}-4$ & 185.16 & 1545 & & \\
\hline $20 \mathrm{H}-5$ & 186.59 & & 1551 & 1524 \\
\hline $20 \mathrm{H}-5$ & 186.66 & 1575 & & \\
\hline
\end{tabular}

\begin{tabular}{|c|c|c|c|c|}
\hline \multirow{2}{*}{$\begin{array}{l}\text { Core, } \\
\text { section }\end{array}$} & \multirow{2}{*}{$\begin{array}{l}\text { Depth } \\
\operatorname{CSF}(\mathrm{m})\end{array}$} & \multicolumn{3}{|c|}{ Velocity $(\mathrm{m} / \mathrm{s})$} \\
\hline & & $x$-axis & $y$-axis & $z$-axis \\
\hline $20 \mathrm{H}-6$ & 187.93 & & 1548 & 1518 \\
\hline $20 \mathrm{H}-6$ & 187.97 & 1569 & & \\
\hline $21 \mathrm{H}-1$ & 190.16 & 1540 & & \\
\hline $21 \mathrm{H}-2$ & 191.58 & & 1459 & \\
\hline $21 \mathrm{H}-2$ & 191.66 & 1570 & & \\
\hline $21 \mathrm{H}-3$ & 193.04 & 1595 & & \\
\hline $21 \mathrm{H}-4$ & 194.57 & & 1548 & 1523 \\
\hline $21 \mathrm{H}-4$ & 194.65 & 1553 & & \\
\hline $21 \mathrm{H}-5$ & 196.10 & & 1551 & 1521 \\
\hline $21 \mathrm{H}-5$ & 196.16 & 1552 & & \\
\hline $21 \mathrm{H}-6$ & 197.57 & & 1548 & 1520 \\
\hline $21 \mathrm{H}-6$ & 197.65 & 1575 & & \\
\hline $22 \mathrm{H}-2$ & 201.15 & 1580 & & \\
\hline $22 \mathrm{H}-3$ & 202.57 & 1572 & & \\
\hline $22 \mathrm{H}-4$ & 204.09 & & 1575 & 1484 \\
\hline $22 \mathrm{H}-4$ & 204.17 & 1583 & & \\
\hline $22 \mathrm{H}-6$ & 206.62 & 1542 & & \\
\hline $23 X-1$ & 208.35 & 1598 & & \\
\hline $23 X-3$ & 211.24 & 1600 & & \\
\hline $23 X-4$ & 212.77 & & 1432 & \\
\hline $23 X-4$ & 213.01 & 1597 & & \\
\hline $23 X-5$ & 214.49 & 1606 & & \\
\hline $23 X-6$ & 215.83 & 1578 & & \\
\hline $23 X-6$ & 215.83 & & 1433 & \\
\hline $24 X-2$ & 217.34 & 1600 & & \\
\hline $24 X-5$ & 221.93 & 1639 & & \\
\hline $24 X-6$ & 223.44 & 1623 & & \\
\hline $25 X-1$ & 225.49 & 1627 & & \\
\hline $25 X-2$ & 226.96 & & 1635 & \\
\hline $25 X-2$ & 227.04 & 1602 & & \\
\hline $25 X-3$ & 228.35 & 1638 & & \\
\hline $25 X-4$ & 230.06 & 1633 & & \\
\hline $25 X-5$ & 231.55 & 1654 & & \\
\hline $25 X-6$ & 232.97 & 1614 & & \\
\hline $26 X-1$ & 235.05 & 1613 & & \\
\hline $26 \mathrm{X}-2$ & 236.57 & 1638 & & \\
\hline $26 X-3$ & 237.94 & 1652 & & \\
\hline $26 X-4$ & 239.56 & 1675 & & \\
\hline $26 X-5$ & 241.06 & 1656 & & \\
\hline $26 X-6$ & 242.55 & 1607 & & \\
\hline $27 X-1$ & 244.61 & 1618 & & \\
\hline $28 X-1$ & 254.23 & 1623 & & \\
\hline $28 X-2$ & 255.76 & 1609 & & \\
\hline $28 X-3$ & 257.14 & 3281 & & \\
\hline $28 X-4$ & 258.76 & 1617 & & \\
\hline $28 X-5$ & 260.15 & 1656 & & \\
\hline $29 X-2$ & 263.75 & 1628 & & \\
\hline $29 X-3$ & 265.02 & 1660 & & \\
\hline $29 X-4$ & 266.51 & 1659 & & \\
\hline $29 X-5$ & 268.25 & 1633 & & \\
\hline $29 X-6$ & 269.14 & 1628 & & \\
\hline $29 X-7$ & 270.92 & 1619 & & \\
\hline $30 \mathrm{X}-1$ & 273.40 & 1649 & & \\
\hline $30 X-2$ & 275.04 & 1664 & & \\
\hline $30 X-3$ & 276.45 & 1622 & & \\
\hline $30 X-6$ & 280.55 & 1695 & & \\
\hline
\end{tabular}


Table T29. Thermal conductivity, Hole U1334A.

\begin{tabular}{lrc}
\hline $\begin{array}{l}\text { Core, section, } \\
\text { interval }(\mathrm{cm})\end{array}$ & $\begin{array}{c}\text { Depth } \\
\text { CSF }(\mathrm{m})\end{array}$ & $\begin{array}{c}\text { Thermal } \\
\text { conductivity } \\
(\mathrm{W} /[\mathrm{m} \cdot \mathrm{K}])\end{array}$ \\
\hline $320-\mathrm{U} 1334 \mathrm{~A}-$ & & \\
$1 \mathrm{H}-3,115$ & 4.15 & 0.780 \\
$2 \mathrm{H}-3,115$ & 12.35 & 0.763 \\
$3 \mathrm{H}-3,115$ & 21.85 & 0.878 \\
$4 \mathrm{H}-3,115$ & 31.35 & 0.834 \\
$5 \mathrm{H}-3,115$ & 40.85 & 0.846 \\
$6 \mathrm{H}-3,115$ & 50.35 & 1.227 \\
$7 \mathrm{H}-3,115$ & 59.85 & 1.109 \\
$8 \mathrm{H}-3,115$ & 69.35 & 1.097 \\
$9 \mathrm{H}-3,115$ & 78.85 & 1.083 \\
$10 \mathrm{H}-3,115$ & 88.35 & 1.069 \\
$11 \mathrm{H}-3,115$ & 97.85 & 1.089 \\
$12 \mathrm{H}-3,115$ & 107.35 & 1.174 \\
$13 \mathrm{H}-3,115$ & 115.85 & 1.182 \\
$14 \mathrm{H}-3,115$ & 126.35 & 1.121 \\
$15 \mathrm{H}-3,115$ & 135.85 & 1.138 \\
$16 \mathrm{H}-3,115$ & 145.35 & 1.141 \\
$17 \mathrm{H}-3,80$ & 154.50 & 1.253 \\
$18 \mathrm{H}-3,115$ & 164.35 & 1.274 \\
$19 \mathrm{H}-3,115$ & 173.77 & 1.202 \\
$20 \mathrm{H}-3,115$ & 183.35 & 1.185 \\
$21 \mathrm{H}-3,115$ & 192.85 & 1.254 \\
$22 \mathrm{H}-3,115$ & 202.35 & 1.291 \\
$23 \mathrm{X}-3,115$ & 211.05 & 1.132 \\
$24 \mathrm{X}-3,115$ & 218.65 & 1.139 \\
$25 \mathrm{X}-3,115$ & 228.25 & 1.102 \\
$26 \mathrm{X}-3,115$ & 237.75 & 1.076 \\
$27 \mathrm{X}-3,90$ & 247.10 & 0.855 \\
$28 \mathrm{X}-3,115$ & 256.95 & 0.883 \\
$30 \mathrm{X}-3,115$ & 276.25 & 0.972 \\
\hline & &
\end{tabular}


Table T30. Shipboard core top, composite, and corrected composite depths, Site U1334.

\begin{tabular}{|c|c|c|c|c|}
\hline \multirow[b]{2}{*}{ Core } & \multirow{2}{*}{$\begin{array}{c}\text { Depth } \\
\text { CSF (m) }\end{array}$} & \multirow{2}{*}{$\begin{array}{l}\text { Offset } \\
(\mathrm{m})\end{array}$} & \multicolumn{2}{|c|}{ Top depth $(\mathrm{m})$} \\
\hline & & & CCSF-A & CCSF-B \\
\hline \multicolumn{5}{|c|}{ 320-U1334A- } \\
\hline $1 \mathrm{H}$ & 0.00 & 0.00 & 0.00 & 0.00 \\
\hline $2 \mathrm{H}$ & 8.20 & 0.87 & 9.07 & 7.82 \\
\hline $3 \mathrm{H}$ & 17.70 & 1.97 & 19.67 & 16.96 \\
\hline $4 \mathrm{H}$ & 27.20 & 3.48 & 30.68 & 26.45 \\
\hline $5 \mathrm{H}$ & 36.70 & 4.77 & 41.47 & 35.75 \\
\hline $6 \mathrm{H}$ & 46.20 & 6.93 & 53.13 & 45.80 \\
\hline $7 \mathrm{H}$ & 55.70 & 7.42 & 63.12 & 54.41 \\
\hline $8 \mathrm{H}$ & 65.20 & 9.06 & 74.26 & 64.02 \\
\hline $9 \mathrm{H}$ & 74.70 & 11.22 & 85.92 & 74.07 \\
\hline $10 \mathrm{H}$ & 84.20 & 11.31 & 95.51 & 82.33 \\
\hline $11 \mathrm{H}$ & 93.70 & 12.92 & 106.62 & 91.92 \\
\hline $12 \mathrm{H}$ & 103.20 & 14.15 & 117.35 & 101.16 \\
\hline $13 \mathrm{H}$ & 112.70 & 15.44 & 128.14 & 110.47 \\
\hline $14 \mathrm{H}$ & 122.20 & 16.93 & 139.13 & 119.94 \\
\hline $15 \mathrm{H}$ & 131.70 & 18.86 & 150.56 & 129.80 \\
\hline $16 \mathrm{H}$ & 141.20 & 20.56 & 161.76 & 139.45 \\
\hline $17 \mathrm{H}$ & 150.70 & 23.22 & 173.92 & 149.93 \\
\hline $18 \mathrm{H}$ & 160.20 & 24.10 & 184.30 & 158.88 \\
\hline $19 \mathrm{H}$ & 169.70 & 26.42 & 196.12 & 169.07 \\
\hline $20 \mathrm{H}$ & 179.20 & 26.98 & 206.18 & 177.74 \\
\hline $21 \mathrm{H}$ & 188.70 & 30.00 & 218.70 & 188.53 \\
\hline $22 \mathrm{H}$ & 198.20 & 42.70 & 240.90 & 207.67 \\
\hline $23 x$ & 206.90 & 44.30 & 251.20 & 216.55 \\
\hline $24 X$ & 214.50 & 46.90 & 261.40 & 225.34 \\
\hline $25 x$ & 224.10 & 47.40 & 271.50 & 234.05 \\
\hline $26 x$ & 233.60 & 47.71 & 281.31 & 242.51 \\
\hline $27 X$ & 243.20 & 49.24 & 292.44 & 252.10 \\
\hline $28 x$ & 252.80 & 48.91 & 301.71 & 260.09 \\
\hline $29 x$ & 262.40 & 49.68 & 312.08 & 269.04 \\
\hline $30 x$ & 272.10 & 50.97 & 323.07 & 278.51 \\
\hline $31 x$ & 281.80 & 51.48 & 333.28 & 287.31 \\
\hline $32 X$ & 285.00 & 51.48 & 336.48 & 290.07 \\
\hline \multicolumn{5}{|c|}{ 320-U1334B- } \\
\hline $1 \mathrm{H}$ & 3.70 & 4.00 & 7.70 & 6.64 \\
\hline $2 \mathrm{H}$ & 13.20 & 4.69 & 17.89 & 15.42 \\
\hline $3 \mathrm{H}$ & 22.70 & 4.64 & 27.34 & 23.57 \\
\hline $4 \mathrm{H}$ & 32.20 & 6.27 & 38.47 & 33.16 \\
\hline $5 \mathrm{H}$ & 41.70 & 5.99 & 47.69 & 41.11 \\
\hline $6 \mathrm{H}$ & 49.20 & 7.31 & 56.51 & 48.71 \\
\hline $7 \mathrm{H}$ & 58.70 & 9.29 & 67.99 & 58.61 \\
\hline $8 \mathrm{H}$ & 68.20 & 12.14 & 80.34 & 69.26 \\
\hline $9 \mathrm{H}$ & 77.70 & 14.35 & 92.05 & 79.36 \\
\hline $10 \mathrm{H}$ & 87.20 & 15.44 & 102.64 & 88.48 \\
\hline $11 \mathrm{H}$ & 96.70 & 17.09 & 113.79 & 98.10 \\
\hline $12 \mathrm{H}$ & 106.20 & 17.28 & 123.48 & 106.45 \\
\hline $13 \mathrm{H}$ & 115.70 & 18.99 & 134.69 & 116.12 \\
\hline $14 \mathrm{H}$ & 125.20 & 21.74 & 146.94 & 126.67 \\
\hline $15 \mathrm{H}$ & 134.70 & 22.49 & 157.19 & 135.51 \\
\hline $16 \mathrm{H}$ & 144.20 & 23.79 & 167.99 & 144.82 \\
\hline
\end{tabular}

\begin{tabular}{|c|c|c|c|c|}
\hline \multirow[b]{2}{*}{ Core } & \multirow{2}{*}{$\begin{array}{c}\text { Depth } \\
\text { CSF }(m)\end{array}$} & \multirow{2}{*}{$\begin{array}{l}\text { Offset } \\
(\mathrm{m})\end{array}$} & \multicolumn{2}{|c|}{ Top depth (m) } \\
\hline & & & CCSF-A & CCSF-B \\
\hline $17 \mathrm{H}$ & 153.70 & 25.14 & 178.84 & 154.17 \\
\hline $18 \mathrm{H}$ & 163.20 & 27.10 & 190.30 & 164.05 \\
\hline $19 \mathrm{H}$ & 172.70 & 28.25 & 200.95 & 173.23 \\
\hline $20 \mathrm{H}$ & 182.20 & 30.80 & 213.00 & 183.62 \\
\hline $21 \mathrm{H}$ & 191.70 & 32.95 & 224.65 & 193.66 \\
\hline $22 \mathrm{H}$ & 201.20 & 32.95 & 234.15 & 201.85 \\
\hline $23 x$ & 210.70 & 34.66 & 245.36 & 211.52 \\
\hline $24 X$ & 219.00 & 47.60 & 266.60 & 229.83 \\
\hline $25 X$ & 228.60 & 48.79 & 277.39 & 239.13 \\
\hline $26 \mathrm{X}$ & 238.20 & 50.39 & 288.59 & 248.78 \\
\hline $27 X$ & 247.80 & 49.72 & 297.52 & 256.48 \\
\hline $28 \mathrm{X}$ & 257.40 & 50.80 & 308.20 & 265.69 \\
\hline $29 \mathrm{X}$ & 267.00 & 53.11 & 320.11 & 275.96 \\
\hline $30 x$ & 276.60 & 53.72 & 330.32 & 284.76 \\
\hline $31 x$ & 283.90 & 53.72 & 337.62 & 291.05 \\
\hline \multicolumn{5}{|c|}{ 320-U1334C- } \\
\hline $1 \mathrm{H}$ & 0 & 3.65 & 3.65 & 3.15 \\
\hline $2 \mathrm{H}$ & 9.5 & 4.33 & 13.83 & 11.93 \\
\hline $3 \mathrm{H}$ & 19 & 6.65 & 25.65 & 22.11 \\
\hline $4 \mathrm{H}$ & 28.5 & 10.04 & 38.54 & 33.22 \\
\hline $5 \mathrm{H}$ & 38 & 10.11 & 48.11 & 41.47 \\
\hline $6 \mathrm{H}$ & 47.5 & 12.06 & 59.56 & 51.34 \\
\hline $7 \mathrm{H}$ & 57 & 12.06 & 69.06 & 59.53 \\
\hline $8 \mathrm{H}$ & 66.5 & 13.96 & 80.46 & 69.36 \\
\hline $9 \mathrm{H}$ & 76 & 16.30 & 92.30 & 79.57 \\
\hline $10 \mathrm{H}$ & 85.5 & 17.98 & 103.48 & 89.20 \\
\hline $11 \mathrm{H}$ & 95 & 19.69 & 114.69 & 98.87 \\
\hline $12 \mathrm{H}$ & 104.5 & 22.75 & 127.25 & 109.69 \\
\hline $13 \mathrm{H}$ & 114 & 25.13 & 139.13 & 119.94 \\
\hline $14 \mathrm{H}$ & 123.5 & 27.06 & 150.56 & 129.79 \\
\hline $15 \mathrm{H}$ & 133 & 28.23 & 161.23 & 138.99 \\
\hline $16 \mathrm{H}$ & 142.5 & 29.69 & 172.19 & 148.44 \\
\hline $17 \mathrm{H}$ & 152 & 30.35 & 182.35 & 157.20 \\
\hline $18 \mathrm{H}$ & 161.5 & 31.44 & 192.94 & 166.32 \\
\hline $19 \mathrm{H}$ & 171 & 32.52 & 203.52 & 175.45 \\
\hline $20 \mathrm{H}$ & 180.5 & 33.77 & 214.27 & 184.72 \\
\hline $21 \mathrm{H}$ & 190 & 34.20 & 224.20 & 193.27 \\
\hline $22 \mathrm{H}$ & 199.5 & 35.80 & 235.30 & 202.84 \\
\hline $23 x$ & 209 & 40.93 & 249.93 & 215.46 \\
\hline $24 X$ & 214 & 44.20 & 258.20 & 222.59 \\
\hline $25 x$ & 223.6 & 44.30 & 267.90 & 230.95 \\
\hline $26 X$ & 233.2 & 45.17 & 278.37 & 239.97 \\
\hline $27 X$ & 239.2 & 46.08 & 285.28 & 245.93 \\
\hline $28 \mathrm{X}$ & 248.8 & 47.12 & 295.92 & 255.11 \\
\hline $29 X$ & 258.4 & 53.90 & 312.30 & 269.23 \\
\hline $30 x$ & 268 & 54.52 & 322.52 & 278.04 \\
\hline $31 X$ & 277.7 & 56.73 & 334.43 & 288.30 \\
\hline $32 X$ & 279.7 & 56.73 & 336.43 & 290.02 \\
\hline $33 x$ & 280.2 & 56.73 & 336.93 & 290.45 \\
\hline
\end{tabular}


Table T31. Splice tie points, Site U1334. (See table notes.)

\begin{tabular}{|c|c|c|c|c|c|c|}
\hline \multirow{2}{*}{$\begin{array}{l}\text { Hole, core, section, } \\
\text { interval }(\mathrm{cm})\end{array}$} & \multicolumn{2}{|c|}{ Depth $(\mathrm{m})$} & & \multirow{2}{*}{$\begin{array}{l}\text { Hole, core, section, } \\
\text { interval }(\mathrm{cm})\end{array}$} & \multicolumn{2}{|c|}{ Depth $(m)$} \\
\hline & CSF & CCSF-A & & & CSF & CCSF-A \\
\hline $320-$ & & & & $320-$ & & \\
\hline U1334A-1H-5, 80 & 6.80 & 6.80 & Tie to & U1334C-1H-3, 15 & 3.15 & 6.80 \\
\hline U1334C-1H-5, 69 & 6.69 & 10.35 & Tie to & U1334A-2H-1, 128 & 9.48 & 10.35 \\
\hline U1334A-2H-6, 132 & 17.02 & 17.89 & Tie to & U1334C-2H-4, 10 & 13.56 & 17.89 \\
\hline U1334C-2H-5, 108 & 16.04 & 20.37 & Tie to & U1334A-3H-1, 70 & 18.40 & 20.37 \\
\hline U1334A-3H-6, 145 & 26.65 & 28.62 & Tie to & U1334B-3H-1, 128 & 23.98 & 28.62 \\
\hline U1334B-3H-5, 114 & 29.84 & 34.48 & Tie to & U1334A-4H-3, 80 & 31.00 & 34.48 \\
\hline U1334A-4H-6, 139 & 36.09 & 39.57 & Tie to & U1334B-4H-1, 110 & 33.30 & 39.57 \\
\hline U1334B-4H-6, 145 & 41.15 & 47.42 & Tie to & U1334A-5H-4, 144 & 42.64 & 47.42 \\
\hline U1334A-5H-6, 30 & 44.50 & 49.27 & Tie to & U1334C-5H-1, 116 & 39.16 & 49.27 \\
\hline U1334C-5H-7, 5 & 47.05 & 57.16 & Tie to & U1334A-6H-3, 103 & 50.23 & 57.16 \\
\hline U1334A-6H-6, 23 & 53.93 & 60.86 & Tie to & U1334C-6H-1, 130 & 48.80 & 60.86 \\
\hline U1334C-6H-5, 149 & 54.99 & 67.05 & Tie to & U1334A-7H-3, 93 & 59.63 & 67.05 \\
\hline U1334A-7H-6, 68 & 63.88 & 71.30 & Tie to & U1334B-7H-3, 31 & 62.01 & 71.30 \\
\hline U1334B-7H-6, 102 & 67.22 & 76.51 & Tie to & U1334A-8H-2, 76 & 67.46 & 76.51 \\
\hline U1334A-8H-6, 128 & 73.98 & 83.04 & Tie to & U1334B-8H-2, 119 & 70.89 & 83.04 \\
\hline U1334B-8H-5, 75 & 74.95 & 87.10 & Tie to & U1334A-9H-1, 118 & 75.88 & 87.10 \\
\hline U1334A-9H-6, 20 & 82.40 & 93.61 & Tie to & U1334B-9H-2, 6 & 79.26 & 93.61 \\
\hline U1334B-9H-5, 74 & 84.44 & 98.80 & Tie to & U1334A-10H-3, 29 & 87.49 & 98.80 \\
\hline U1334A-10H-6, 142 & 93.12 & 104.43 & Tie to & U1334C-10H-1, 95 & 86.45 & 104.43 \\
\hline U1334C-10H-5, 37 & 91.87 & 109.84 & Tie to & U1334A-11H-3, 22 & 96.92 & 109.84 \\
\hline U1334A-11H-6, 132 & 102.52 & 115.44 & Tie to & U1334B-11H-2, 14 & 98.34 & 115.44 \\
\hline U1334B-11H-6, 100 & 105.20 & 122.30 & Tie to & U1334A-12H-4, 45 & 108.15 & 122.30 \\
\hline U1334A-12H-6, 43 & 111.13 & 125.27 & Tie to & U1334B-12H-2, 29 & 107.99 & 125.27 \\
\hline U1334B-12H-6, 39 & 114.09 & 131.37 & Tie to & U1334C-12H-3, 113 & 108.63 & 131.37 \\
\hline U1334C-12H-7, 36 & 113.86 & 136.61 & Tie to & U1334B-13H-2, 41 & 117.61 & 136.61 \\
\hline U1334B-13H-5, 5 & 121.75 & 140.75 & Tie to & U1334C-13H-2, 12 & 115.62 & 140.75 \\
\hline U1334C-13H-6, 86 & 122.36 & 147.49 & Tie to & U1334B-14H-1, 55 & 125.75 & 147.49 \\
\hline U1334B-14H-4, 101 & 130.71 & 152.45 & Tie to & U1334C-14H-2, 39 & 125.39 & 152.45 \\
\hline U1334C-14H-6, 44 & 131.44 & 158.49 & Tie to & U1334B-15H-1, 130 & 136.00 & 158.49 \\
\hline U1334B-15H-6, 129 & 143.49 & 165.99 & Tie to & U1334C-15H-4, 26 & 137.76 & 165.99 \\
\hline U1334C-15H-6, 74 & 141.24 & 169.47 & Tie to & U1334B-16H-1, 148 & 145.68 & 169.47 \\
\hline U1334B-16H-5, 75 & 150.95 & 174.74 & Tie to & U1334C-16H-2, 105 & 145.05 & 174.74 \\
\hline U1334C-16H-6, 53 & 150.53 & 180.22 & Tie to & U1334B-17H-1, 138 & 155.08 & 180.22 \\
\hline U1334B-17H-6, 67 & 161.87 & 187.01 & Tie to & U1334A-18H-2, 122 & 162.92 & 187.01 \\
\hline U1334A-18H-5, 53 & 166.73 & 190.83 & Tie to & U1334B-18H-1, 53 & 163.73 & 190.83 \\
\hline U1334B-18H-6, 126 & 171.96 & 199.06 & Tie to & U1334A-19H-3, 2 & 172.64 & 199.06 \\
\hline U1334A-19H-6, 19 & 177.31 & 203.72 & Tie to & U1334B-19H-2, 127 & 175.47 & 203.72 \\
\hline U1334B-19H-4, 12 & 177.32 & 205.57 & Tie to & U1334C-19H-2, 55 & 173.05 & 205.57 \\
\hline U1334C-19H-5, 105 & 178.05 & 210.57 & Tie to & U1334A-20H-3, 139 & 183.59 & 210.57 \\
\hline U1334A-20H-6, 98 & 187.68 & 214.67 & Tie to & U1334B-20H-2, 16 & 183.86 & 214.67 \\
\hline U1334B-20H-7, 34 & 191.34 & 222.15 & Append to & U1334B-21H-1, 38 & 192.08 & 225.03 \\
\hline U1334B-21H-7, 36 & 201.06 & 234.01 & Append to & U1334B-22H-1, 15 & 201.35 & 234.30 \\
\hline U1334B-22H-7, 67 & 210.87 & 243.82 & Append to & U1334B-23X-1, 30 & 211.00 & 245.66 \\
\hline U1334B-23 X-5, 118 & 217.88 & 252.54 & Tie to & U1334A-23X-1, 134 & 208.24 & 252.54 \\
\hline U1334A-23 X-6, 110 & 215.50 & 259.80 & Tie to & U1334C-24X-2, 10 & 215.60 & 259.80 \\
\hline U1334C-24 X-6, 137 & 222.87 & 267.07 & Tie to & U1334A-24X-4, 117 & 220.17 & 267.07 \\
\hline U1334A-24 X-5, 116 & 221.66 & 268.56 & Tie to & U1334C-25X-1, 66 & 224.26 & 268.56 \\
\hline U1334C-25 X-5, 22 & 229.82 & 274.12 & Tie to & U1334A-25X-2, 112 & 226.72 & 274.12 \\
\hline U1334A-25 X-6, 75 & 232.35 & 279.75 & Tie to & U1334C-26X-1, 138 & 234.58 & 279.75 \\
\hline U1334C-26 X-5, 25 & 239.45 & 284.62 & Tie to & U1334A-26X-3, 31 & 236.91 & 284.62 \\
\hline U1334A-26 X-6, 91 & 242.01 & 289.72 & Tie to & U1334B-26X-1, 113 & 239.33 & 289.72 \\
\hline U1334B-26 X-6, 77 & 246.47 & 296.86 & Tie to & U1334C-28X-1, 93 & 249.73 & 296.86 \\
\hline U1334C-28 X-6, 127 & 257.57 & 304.69 & Tie to & U1334A-28X-2, 149 & 255.79 & 304.69 \\
\hline U1334A-28 X-6, 113 & 261.43 & 310.33 & Tie to & U1334B-28X-2, 63 & 259.53 & 310.33 \\
\hline U1334B-28 X-4, 26 & 262.16 & 312.96 & Tie to & U1334C-29X-1, 66 & 259.06 & 312.96 \\
\hline U1334C-29 X-6, 129 & 267.19 & 321.10 & Tie to & U1334B-29X-1, 99 & 267.99 & 321.10 \\
\hline U1334B-29 X-6, 90 & 275.40 & 328.51 & Tie to & U1334C-30X-4, 149 & 273.99 & 328.51 \\
\hline U1334C-30 X-6, 135 & 276.85 & 331.38 & Tie to & U1334B-30-1, 105 & 277.65 & 331.38 \\
\hline
\end{tabular}

Notes: Spliced section is interrupted between 222 and 245.7 m CCSF-A because of coring gaps and lack of correlation. Sampling in this depth interval will not recover a complete stratigraphic sequence. 
Table T32. Magnetostratigraphic and biostratigraphic datums, Site U1334. (See table note.)

\begin{tabular}{|c|c|c|c|c|c|c|c|}
\hline Event & $\begin{array}{l}\text { Age } \\
(\mathrm{Ma})\end{array}$ & $\begin{array}{c}\text { Depth } \\
\text { CCSF-A }(\mathrm{m})\end{array}$ & $\begin{array}{l}\text { Error } \\
(\mathrm{m})\end{array}$ & Event & $\begin{array}{l}\text { Age } \\
\text { (Ma) }\end{array}$ & $\begin{array}{c}\text { Depth } \\
\text { CCSF-A }(\mathrm{m})\end{array}$ & $\begin{array}{l}\text { Error } \\
(\mathrm{m})\end{array}$ \\
\hline C1n-C1r.1r & 0.781 & 0.60 & & B Discoaster petaliformis & 15.70 & 32.01 & 0.88 \\
\hline C5n.1r-C5n.2n & 9.987 & 12.22 & & B Sphenolithus heteromorphus & 17.71 & 39.11 & 0.73 \\
\hline C5n.2n-C5r.1r & 11.040 & 14.29 & & T Triquetrorhabdulus carinatus & 18.28 & 46.32 & 0.85 \\
\hline C5r.1r-C5r.1n & 11.118 & 14.39 & & Tac Triquetrorhabdulus carinatus & 22.09 & 90.27 & 1.15 \\
\hline C5r.1n-C5r.2r & 11.154 & 14.57 & & B Sphenolithus disbelemnos & 22.8 & 95.59 & 0.37 \\
\hline C $5 r .2 r-C 5 r .2 n$ & 11.554 & 15.54 & & T Sphenolithus delphix & 23.1 & 105.03 & 0.23 \\
\hline C5r.2n-C5r.3r & 11.614 & 15.72 & & B Sphenolithus delphix & 23.2 & 108.37 & 0.75 \\
\hline C5r.3r-C5An.1n & 12.014 & 16.79 & & T Sphenolithus ciperoensis & 24.4 & 126.57 & 0.16 \\
\hline C5An.1n-C5An.1r & 12.116 & 17.09 & & $\mathrm{X} T$. longus/T. carinatus & 24.7 & 128.31 & 0.29 \\
\hline C5An.1r-C5An.2n & 12.207 & 17.39 & & Tc Cyclicargolithus abisectus & 24.7 & 128.31 & 0.29 \\
\hline C5An.2n-C5Ar.1r & 12.415 & 18.32 & & T Sphenolithus distentus & 26.8 & 169.89 & 0.23 \\
\hline C5Ar.1r-C5Ar.1n & 12.730 & 20.27 & & T Sphenolithus predistentus & 26.9 & 169.89 & 0.23 \\
\hline C5Ar. $1 n-C 5 A r .2 r$ & 12.765 & 20.37 & & B Sphenolithus ciperoensis & 27.1 & 200.75 & 4.16 \\
\hline C5Ar. $2 r-C 5 A r .2 n$ & 12.820 & 20.82 & & T Sphenolithus pseudoradians & 28.8 & 210.54 & 5.07 \\
\hline C5Ar.2n-C5Ar.3r & 12.878 & 20.92 & & B Sphenolithus distentus & 30.0 & 242.14 & 0.96 \\
\hline C5Ar.3r-C5AAn & 13.015 & 21.67 & & T Reticulofenestra umbilicus & 32.0 & 271.96 & 0.34 \\
\hline C5AAn-C5AAr & 13.183 & 22.29 & & T Isthmolithus recurvus & 32.5 & 293.33 & 0.72 \\
\hline C5AAr-C5ABn & 13.369 & 23.07 & & T Coccolithus formosus & 32.9 & 284.56 & 0.75 \\
\hline $\mathrm{C} 5 \mathrm{ABn}-\mathrm{C} 5 \mathrm{ABr}$ & 13.605 & 24.67 & & T Discoaster saipanensis & 34.4 & 299.47 & 0.53 \\
\hline $\mathrm{C} 5 \mathrm{ABr}-\mathrm{C} 5 \mathrm{ACn}$ & 13.734 & 25.37 & & $\mathrm{~T}$ Reticulofenestra reticulata & 35.2 & 307.98 & 3.55 \\
\hline $\mathrm{C} 5 \mathrm{ACn}-\mathrm{C} 5 \mathrm{ACr}$ & 14.095 & 26.72 & & B Isthmolithus recurvus & 36.6 & 323.35 & 0.38 \\
\hline C5ACr-C5ADn & 14.194 & 26.97 & & T Chiasmolithus oamaruensis & 37.0 & 324.52 & 0.79 \\
\hline C5ADn-C5ADr & 14.581 & 28.69 & & T Chiasmolithus grandis & 37.1 & 324.52 & 0.79 \\
\hline $\mathrm{C} 5 \mathrm{Bn} \cdot 2 \mathrm{n}-\mathrm{C} 5 \mathrm{Br}$ & 15.160 & 31.28 & & B Dictyococcites bisectus & 38.0 & 336.69 & \\
\hline $\mathrm{C} 5 \mathrm{Br}-\mathrm{C} 5 \mathrm{Cn} .1 \mathrm{n}$ & 15.974 & 36.66 & & Radiolarians & & & \\
\hline $\mathrm{C} 5 \mathrm{Cn} .1 \mathrm{n}-\mathrm{C} 5 \mathrm{Cn} .1 \mathrm{r}$ & 16.268 & 33.18 & & $\begin{array}{l}\text { Radiolarians } \\
\text { T Diartus petterssoni }\end{array}$ & 8.63 & 6.88 & 132 \\
\hline C5Cn.1r-C5Cn.2n & 16.303 & 38.56 & & B Diartus hughesi & 8.99 & $\begin{array}{r}0.80 \\
10.34\end{array}$ & $\begin{array}{l}1.32 \\
1.29\end{array}$ \\
\hline C5Cn.2n-C5Cn.2r & 16.472 & 38.86 & & $\begin{array}{l}\text { B Diartus nughesi } \\
\text { B Diartus petterssoni }\end{array}$ & 11.71 & 16.80 & 2.18 \\
\hline C5Cn.2r-C5Cn.3n & 16.543 & 39.28 & & B Lithopera neotera & 12.95 & 21.15 & 1.07 \\
\hline $\mathrm{C} 5 \mathrm{Cn} \cdot 3 \mathrm{n}-\mathrm{C} 5 \mathrm{Cr}$ & 16.721 & 39.66 & & T Stichocorys armata & 13.50 & 23.72 & 1.50 \\
\hline C5Dn-C5Dr & 17.533 & 42.65 & & Dorcadospyris dentata > Dorcadospyris alata & 14.78 & 27.42 & 2.20 \\
\hline C5Dr-C5En & 18.056 & $\begin{array}{l}44.70 \\
47.00\end{array}$ & & B Dorcadospyris alata & 15.08 & 32.19 & 1.06 \\
\hline C5En-C5Er & $\begin{array}{l}18.524 \\
18748\end{array}$ & $\begin{array}{l}47.00 \\
48.22\end{array}$ & & B Lithopera renzae & 16.77 & 41.69 & 1.03 \\
\hline $\mathrm{C} 5 \mathrm{Er}-\mathrm{C} 6 \mathrm{n}$ & 18.748 & 48.22 & & B Dorcadospyris dentata & 17.72 & 45.51 & 1.50 \\
\hline $\mathrm{C} 6 \mathrm{n}-\mathrm{C} 6 \mathrm{r}$ & 19.722 & 57.98 & & B Dorcadospyris forcipata & 18.61 & 49.28 & 2.27 \\
\hline C6r-C6An.1n & $\begin{array}{l}20.040 \\
20.213\end{array}$ & $\begin{array}{l}61.83 \\
65.25\end{array}$ & & T Dorcadospyris praeforcipata & 19.77 & 60.90 & 2.23 \\
\hline $\begin{array}{l}\text { C6An.1n-C6An.1r } \\
\text { C6An.1r-C6An.2n }\end{array}$ & & 65.25 & & T Lophocyrtis pegetrum & 20.89 & 70.88 & 2.21 \\
\hline $\begin{array}{l}\text { C6An.1r-C6An.2n } \\
\text { C6Ar-C6AAn }\end{array}$ & $\begin{array}{l}20.439 \\
21.083\end{array}$ & $\begin{array}{l}68.52 \\
7988\end{array}$ & & B Calocycletta virginis & 21.39 & 75.77 & 1.05 \\
\hline $\begin{array}{l}\text { C6Ar-C6AAn } \\
\text { C6AAn-C6AAr.1r }\end{array}$ & & $\begin{array}{l}79.88 \\
81.58\end{array}$ & & T Eucyrtidium mitodes & 21.95 & 89.97 & 1.50 \\
\hline $\begin{array}{l}\text { C6AAn-C6AAr.1r } \\
\text { C6AAr.3r-C6Bn.1n }\end{array}$ & $\begin{array}{l}21.159 \\
21.767\end{array}$ & $\begin{array}{l}81.58 \\
86.97\end{array}$ & & T Artophormis gracilis & 22.62 & 99.56 & 1.50 \\
\hline $\begin{array}{l}\text { C6AAr.3r-C6Bn.1n } \\
\text { C6Bn.1n-C6Bn.1r }\end{array}$ & 21.936 & $\begin{array}{l}86.97 \\
89.14\end{array}$ & & B Dorcadospyris cyclacantha & 23.29 & 110.67 & 1.50 \\
\hline $\begin{array}{l}\text { C6Bn.1n-C6Bn.1r } \\
\text { C6Bn.1r-C6Bn.2n }\end{array}$ & 21.992 & $\begin{array}{l}09.14 \\
89.74\end{array}$ & & T Lychnocanoma apodora & 24.50 & 131.19 & 1.50 \\
\hline C6Br-C6Cn.1n & 22.564 & 98.21 & & B Calocycletta robusta & 25.27 & 146.78 & 2.11 \\
\hline C6Cn.1n-C6Cn.1r & 22.754 & 99.96 & & T Eucyrtidium plesiodiaphanes & 26.40 & 165.80 & 1.50 \\
\hline C6Cn.1r-C6Cn.2n & 22.902 & 102.16 & & T Lithocyclia angusta & 27.68 & 185.43 & 1.36 \\
\hline C 6 Cn.2n-C 6 Cn.2r & 23.030 & 104.01 & & T Theocyrtis setanios & 28.21 & 199.43 & 1.50 \\
\hline C 6 Cn.2r-C 6 Cn.3n & 23.278 & 107.55 & & B Eucyrtidium mitodes & 29.41 & 226.37 & 2.11 \\
\hline $\mathrm{C} 6 \mathrm{Cn} .3 \mathrm{n}-\mathrm{C} 6 \mathrm{Cr}$ & 23.340 & 108.70 & & T Theocyrtis tuberosa & 30.13 & 252.42 & 1.26 \\
\hline $\mathrm{C} 6 \mathrm{Cr}-\mathrm{C} 7 \mathrm{n} .1 \mathrm{n}$ & 24.022 & 118.97 & & T Lophocyrtis oberhaensliae & 30.74 & 263.51 & 0.44 \\
\hline C7n.1n-C7n.1r & 24.062 & 119.57 & & T Lithocyclia aristotelis gr. & 33.51 & 296.30 & 3.70 \\
\hline C7n.1r-C7n.2n & 24.147 & 120.92 & & B Lithocyclia angusta & 34.13 & 296.30 & 3.70 \\
\hline$C 7 n \cdot 2 n-C 7 r$ & 24.459 & 125.67 & & T Calocyclas turris & 34.83 & 305.11 & 0.65 \\
\hline C7An-C7Ar & 24.984 & 130.42 & & B Calocyclas bandyca & 36.74 & 318.91 & 2.78 \\
\hline C7Ar-C8n.1n & 25.110 & 132.37 & & Foraminifers & & & \\
\hline C $8 n .1 n-C 8 n .1 r$ & 25.248 & 135.29 & & B Globorotalia (Fohsella) foshi robusta & 13.13 & 20.81 & 0.73 \\
\hline $\mathrm{C} 8 \mathrm{n} \cdot 2 \mathrm{n}-\mathrm{C} 8 \mathrm{r}$ & 26.032 & 158.51 & & T Globoquadrina binaiensis & 19.09 & 62.70 & 4.66 \\
\hline $\mathrm{C} 9 \mathrm{n}-\mathrm{C} 9 \mathrm{r}$ & 27.412 & 178.42 & & T Paragloborotalia kugleri & 21.12 & 73.42 & 4.84 \\
\hline C10n.1n-C10n.1r & 28.126 & 190.25 & & T Paragloborotalia pseudokugleri & 21.31 & 73.42 & 4.84 \\
\hline C10n.1r-C10n.2n & 28.164 & 191.32 & & B Globoquadrina dehiscens & 22.44 & 87.08 & 4.84 \\
\hline $\mathrm{C} 10 \mathrm{n} .2 \mathrm{n}-\mathrm{C} 10 \mathrm{r}$ & 28.318 & 197.58 & & B Paragloborotalia kugleri & 23.0 & 105.33 & 4.68 \\
\hline & & & & B Paragloborotalia pseudokugleri & 25.2 & 139.17 & 4.49 \\
\hline $\begin{array}{l}\text { Nannotossils } \\
\text { T Coronocyclus nitescens }\end{array}$ & & & & T Paragloborotalia opima & 26.9 & 171.28 & 1.48 \\
\hline T Coronocyclus nitescens & $\begin{array}{l}12.12 \\
12.45\end{array}$ & $\begin{array}{l}17.77 \\
17.77\end{array}$ & & B Globigerina angulisuturalis & 29.2 & 203.11 & 1.50 \\
\hline & $\begin{array}{l}12.45 \\
13.33\end{array}$ & $\begin{array}{l}17.77 \\
22.24\end{array}$ & & T Subbotina angiporoides & 29.8 & 229.25 & 4.85 \\
\hline $\begin{array}{l}\text { Tc Cyclicargolithus floridanus } \\
\text { T Sphenolithus heteromorphus }\end{array}$ & $\begin{array}{l}13.33 \\
13.53\end{array}$ & $\begin{array}{l}22 . \angle 4 \\
25.42\end{array}$ & $\begin{array}{l}0.92 \\
0.75\end{array}$ & T Turborotalia ampliapertura & 30.3 & 239.79 & 4.92 \\
\hline $\begin{array}{l}\text { I Sphenolithus heteromorphus } \\
\text { Tc Discoaster deflandrei }\end{array}$ & $\begin{array}{l}13.53 \\
15.66\end{array}$ & $\begin{array}{l}25.42 \\
32.01\end{array}$ & $\begin{array}{l}0.15 \\
0.88\end{array}$ & B Paragloborotalia opima & 30.8 & 257.41 & 1.89 \\
\hline
\end{tabular}

Note: $\mathrm{T}=$ top, $\mathrm{Tc}=$ top common, $\mathrm{B}=$ bottom, $\mathrm{X}=$ abundance crossover. 
Table T33. Results from APCT-3 temperature profiles, Hole U1334B. (See table notes.)

\begin{tabular}{lccccc}
\hline & \multicolumn{2}{c}{ Temperature $\left({ }^{\circ} \mathrm{C}\right)$} & & & \\
\cline { 2 - 3 } Core & $\begin{array}{c}\text { Average } \\
\text { at } \\
\text { mudline }\end{array}$ & $\begin{array}{c}\text { Minimum } \\
\text { above } \\
\text { mudline }\end{array}$ & $\begin{array}{c}\text { Depth } \\
\text { DSF } \\
(\mathrm{m})\end{array}$ & $\begin{array}{c}\text { In situ } \\
\text { temperature } \\
\left({ }^{\circ} \mathrm{C}\right)\end{array}$ & $\begin{array}{c}\text { Thermal } \\
\text { resistance } \\
\left(\mathrm{m}^{2} \mathrm{~K} / \mathrm{m}\right)\end{array}$ \\
\hline $320-\mathrm{U} 1334 \mathrm{~B}-$ & & & & & \\
3H & 1.522 & 1.450 & 32.2 & 2.82 & 40.6 \\
$5 \mathrm{H}$ & 1.514 & 1.451 & 49.2 & 3.32 & 59.8 \\
7H & 1.527 & 1.457 & 68.2 & 3.59 & 76.7 \\
$9 \mathrm{H}$ & 1.507 & 1.463 & 83.7 & 4.38 & 91.2 \\
11H & 1.510 & 1.466 & 106.2 & 5.09 & 112.1 \\
Average: & 1.516 & 1.457 & & & \\
\hline
\end{tabular}

Notes: In situ temperatures were determined using the TP-Fit software by Martin Heesemann. Thermal resistance was calculated from thermal conductivity data (see "Physical properties") corrected for in situ conditions (see "Downhole measurements" in the "Methods" chapter). 